\title{
Total Synthesis of (-)-Acutumine
}

\author{
Fang Li \\ Brigham Young University - Provo
}

Follow this and additional works at: https://scholarsarchive.byu.edu/etd

Part of the Biochemistry Commons, and the Chemistry Commons

\section{BYU ScholarsArchive Citation}

Li, Fang, "Total Synthesis of (-)-Acutumine" (2009). Theses and Dissertations. 2193.

https://scholarsarchive.byu.edu/etd/2193

This Dissertation is brought to you for free and open access by BYU ScholarsArchive. It has been accepted for inclusion in Theses and Dissertations by an authorized administrator of BYU ScholarsArchive. For more information, please contact scholarsarchive@byu.edu, ellen_amatangelo@byu.edu. 
Total Synthesis of (-)-Acutumine

by

Fang Li

A thesis submitted to the faculty of

Brigham Young University

in partial fulfillment of the requirements for the degree of

Doctor of Philosophy

Department of Chemistry and Biochemistry

Brigham Young University

December 2009 
Copyright $(2009$ Fang Li

All Rights Reserved 


\title{
BRIGHAM YOUNG UNIVERSITY
}

\section{GRADUATE COMMITTEE APPROVAL}

\author{
of a thesis submitted by
}

Fang Li

This thesis has been read by each member of the following graduate committee and by majority vote has been found to be satisfactory.

\section{Date}

\section{Date}

\section{Date}

\section{Date}

Date

\author{
Steven L.Castle, Chair
}

Matt A. Peterson

Paul B. Savage

Roger G. Harrison 


\section{BRIGHAM YOUNG UNIVERSITY}

As chair of the candidate's graduate committee, I have read the thesis of Fang Li in its final form and have found that (1) its format, citations, and bibliographical style are consistent and acceptable and fulfill university and department style requirements; (2) its illustrative materials including figures, tables, and charts are in place; and (3) the final manuscript is satisfactory to the graduate committee and is ready for submission to the university library.

Date

Accepted for the Department
Steven L. Castle

Chair, Graduate Committee
David V. Dearden

Graduate Coordinator

Accepted for the College

Thomas W. Sederberg, Associate Dean College of Physical and Mathematical Sciences 


\begin{abstract}
TOTAL SYNTHESIS OF (-)-ACUTUMINE

Fang Li

Department of Chemistry and Biochemistry

Doctor of Philosophy
\end{abstract}
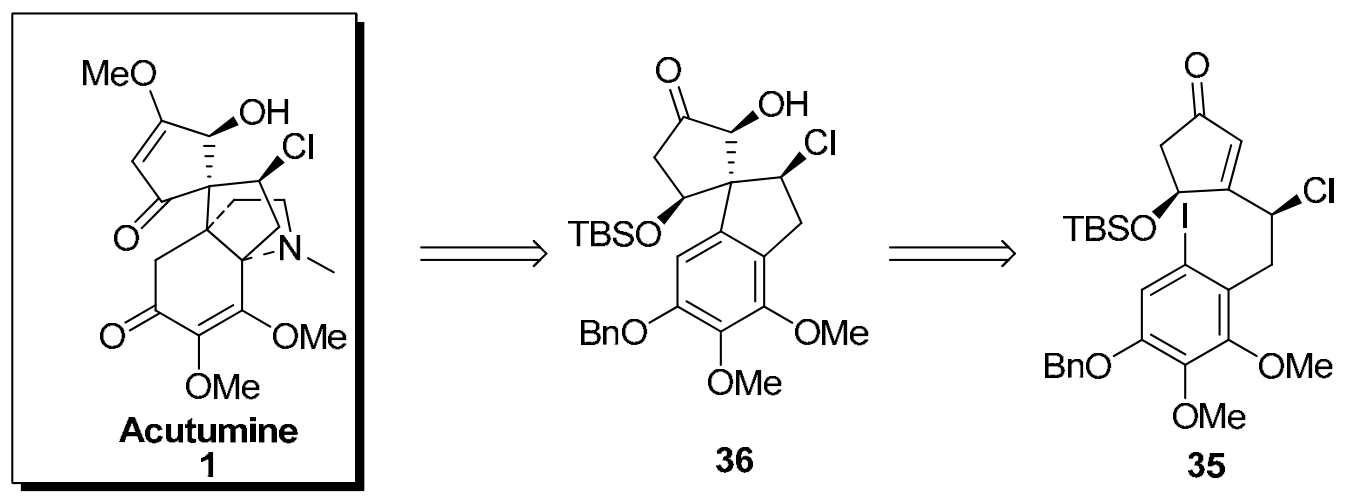

35

Acutumine is a tetracyclic alkaloid isolated from the Asian vine Menispermum dauricum with selective T-cell cytotoxicity and antiamnestic properties. We have developed a total synthetic route to this congested alkaloid, during which we also found a novel, stereoselective radical-crossover reaction that combines an intramolecular 
radical conjugate addition with a subsequent enolate hydroxylation. Key features of this synthesis also include a reagent-controlled diastereoselective ketone allylation, an anionic oxy-Cope rearrangement to form a congested quaternary sterocenter, a pyridine-mediated selective ozonolysis, and a Lewis acid promoted Michael-type cyclization. 


\section{ACKNOWLEDGMENTS}

I am very grateful for the support that I have received throughout this project from Dr. Castle. He has been a great advisor for suggestions on the project as well as advice on career paths.

I would like to thank all of my committee members, Dr. Paul B. Savage, Dr. Merritt B. Andrus., Dr. Matt A. Peterson, Dr. Roger G. Harrison. for their guidance and suggestions.

I also want to thank my associates in Dr. Castle's group who have provided me with intellectual and emotional support.

I gratefully acknowledge the financial support of this work by the Brigham Young University Department of Chemistry and Biochemistry, Bradshaw Organic Chemistry Fellowship, BYU Graduate Research Fellowship.

Most of all I want to express my appreciation to my wife, Chunyan, for bearing a heavy family burden over the past six years. She has been a wonderful wife and mother. Without her significant personal sacrifices my recent scholastic accomplishments would not have come to pass. It is to her and my lovely daughter Amber that I dedicate this dissertation. 


\section{TABLE OF CONTENTS}

LIST OF FIGURES .............................................................................................. ix

LIST OF SCHEMES …..................................................................................................... $\mathrm{x}$

LIST OF TABLES ..............................................................................................

Chapter 1 Introduction....................................................................................................................... 1

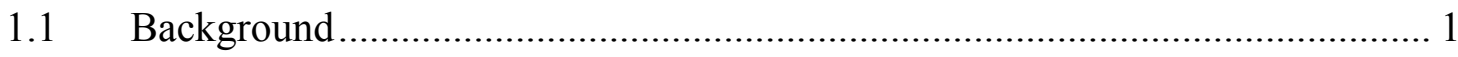

1.2 Discovery and Bioactivity ……………………............................................ 1

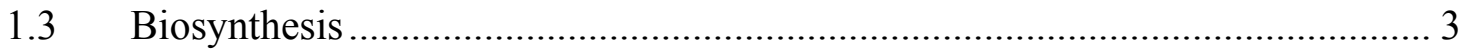

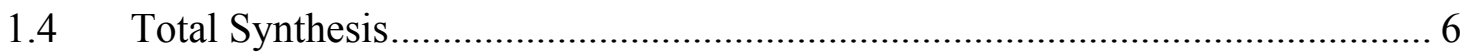

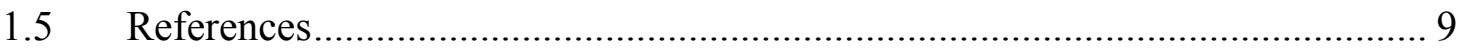

Chapter 2 Investigation of 5-exo Friedel-Crafts Cyclization Onto An Epoxide ....... 11

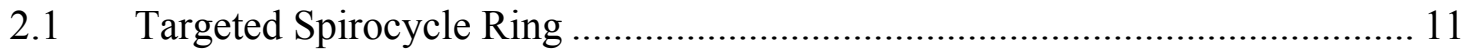

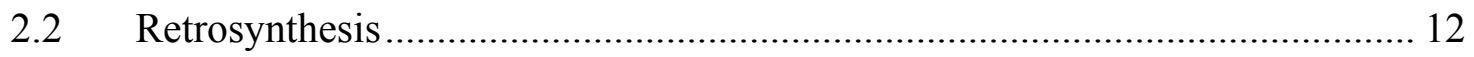

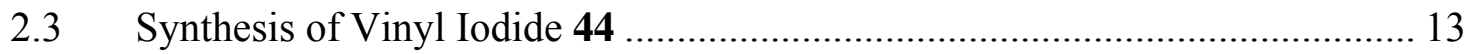

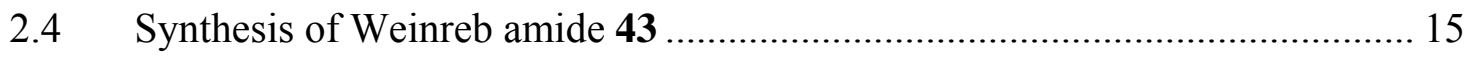

2.5 Coupling and Synthesis of Epoxide 67 ........................................................ 17

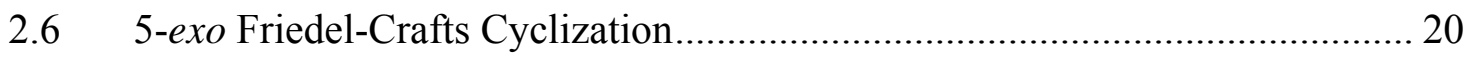

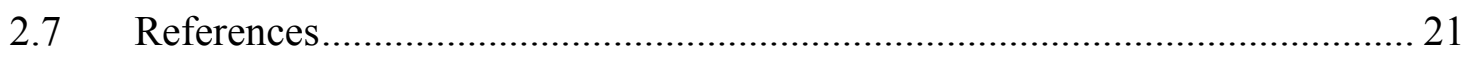

Chapter 3 Radical Cyclization Route to the Spirocycle of Acutumine ....................... 23 
3.1 Retrosynthesis of Radical Cyclization Route ......................................... 23

3.2 Synthesis of Iodinated Weinreb Amide 71 ................................................. 24

3.3 Coupling of the Weinreb Amide and Vinyl Iodide.................................... 25

3.4 Stereoselective Reduction and Chlorination............................................ 26

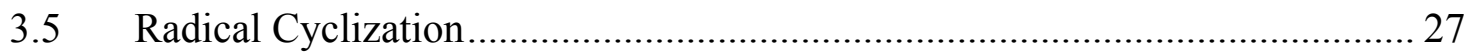

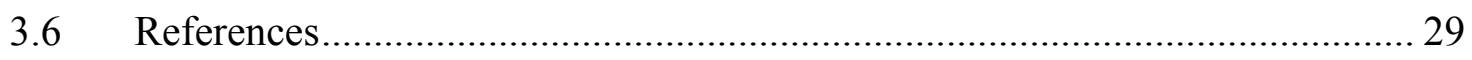

Chapter 4. Radical-polar Cyclization and the Total synthesis of Acutumine ........... 30

4.1 Background of Radical-Polar Crossover Reaction .................................... 30

4.2 Proposed Radical-Polar Crossover Reaction on Our Substrate ...................... 31

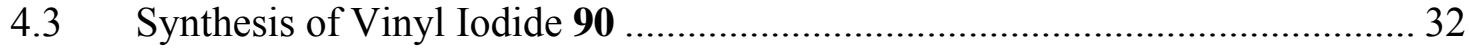

4.4 Synthesis of Cyclization Substrate Enone 35 ......................................... 32

4.5 Radical-Polar Crossover Reaction onto Spirocycle ..................................... 34

4.6 Synthesis of Masked o-Benzoquinone 104 ........................................... 38

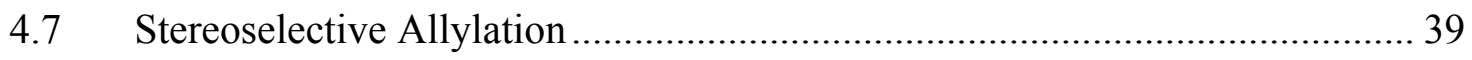

4.8 Exploration of Nakamura Reagent Allylation ....................................... 41

4.9 Anionic Oxy-Cope Rearrangement, Ozonolysis and Reductive Amination .... 42

4.10 Development of Cyclization Conditions in Model System ............................ 44

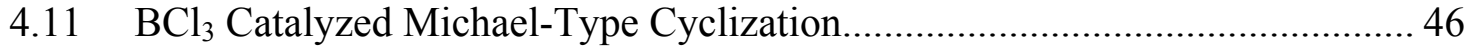

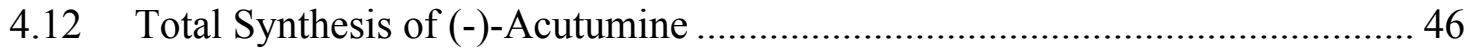

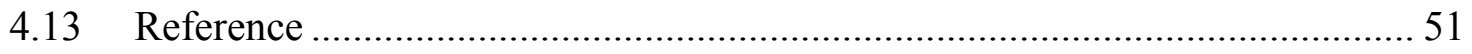

Chapter 5. Conclusion and Future Work ............................................................... 53

5.1 Conclusion and Future Work ................................................................... 53

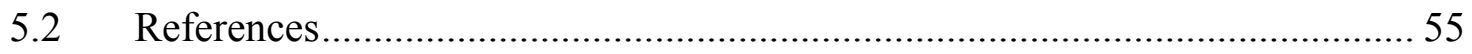

Chapter 6. Experimantal Information .......................................................................... 56 


\section{LIST OF FIGURES}

\section{Chapter 1. Introduction}

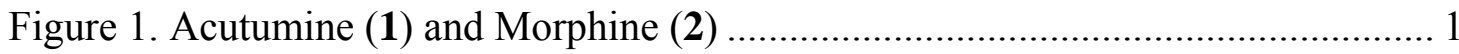

Figure 2. Proposed biosynthetic relationship among acutumine alkaloids................... 3

Figure 3. Hasubanonine (24) and isohasobanonine (25) .................................... 7

\section{Chapter 2. Investigation of 5-exo Friedel-Crafts Cyclization Onto An Epoxide}

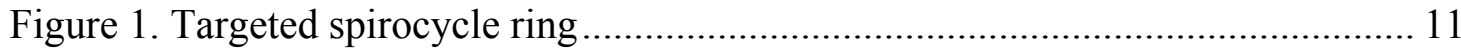

\section{Chapter 4. Radical-Polar Cyclization and the Total synthesis of Acutumine}

Figure 1. NOE enchancement used to assign the structure of 36 ............................ 34

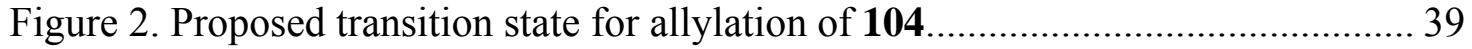

Figure 3. Comparison of ${ }^{1} \mathrm{H}$ NMR spectroscopy between synthetic and natural acutumine

Figure 4. Comparison of ${ }^{13} \mathrm{C}$ NMR spectroscopy between synthetic and natural acutumine. 


\section{LIST OF SCHEMES}

\section{Chapter 1. Introduction}

Scheme 1. Barton's proposal for the biosynthesis of acutumine 1 ............................ 4

Scheme 2. Epoxidation lead to formation of lactone or spiro keto ester ....................... 5

Scheme 3. Wipf's modified proposal for the biosynthesis of acutumine 1 .................. 6

Scheme 4. Sorensen's synthesisof tricyclic core structure of Acutumine 1................. 7

Scheme 5. Reeder's tricycle core structure synthesis........................................ 8

Scheme 6. Radical-polar crossover reaction.................................................... 8

\section{Chapter 2. Investigation of 5-exo Friedel-Crafts Cyclization Onto An Epoxide}

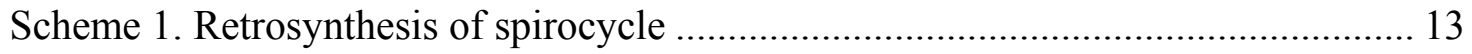

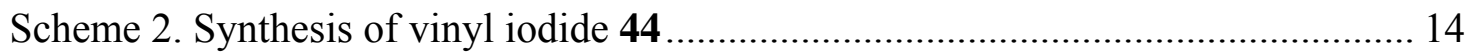

Scheme 3. Demethylation of trimethody benzaldehyde ........................................ 15

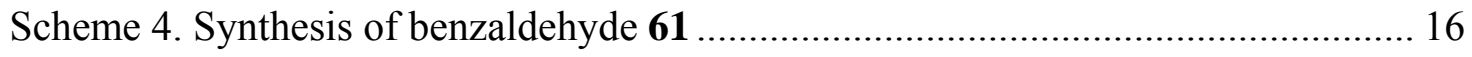

Scheme 5. Synthesis of homologous benzaldehyde 63 through sulfur ylide............... 16

Scheme 6. Synthesis of homologous benzaldehyde 63 through wittig reaction.......... 17

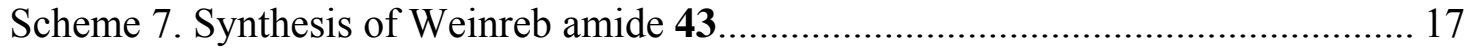

Scheme 8. Coupling and synthesis of the epoxide 67....................................... 19

Scheme 9. 5-exo Friedel-Crafts cyclization ..................................................... 20

\section{Chapter 3. Radical Cyclization Route to the Spirocycle of Acutumine}

Scheme 1. Retrosynthesis of radical cyclization ................................................ 23

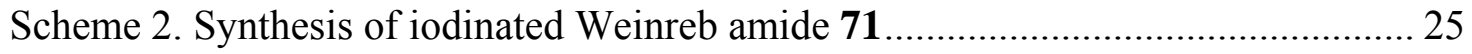


Scheme 3. Grignard reagent promoted coupling reaction .................................... 26

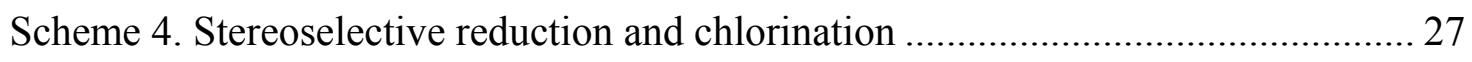

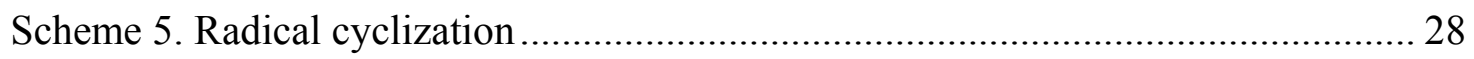

\section{Chapter 4. Radical-polar Cyclization and the Total synthesis of Acutumine}

Scheme 1. Kunz's radical conjugate addition-enolate hydroxylation ......................... 31

Scheme 2. Proposed radical-polar crossover reaction ........................................... 31

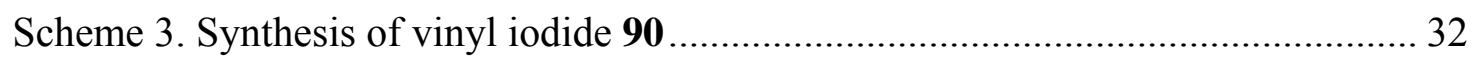

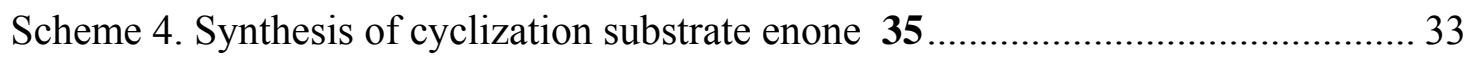

Scheme 5. Radical-polar crossover reaction...................................................... 34

Scheme 6. Proposed radical-polar crossover reaction mechanism in our substrate ..... 37

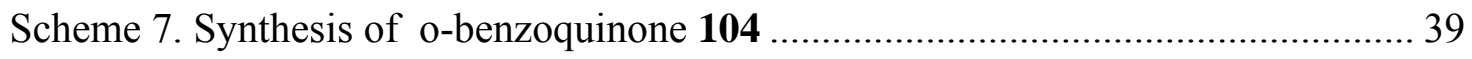

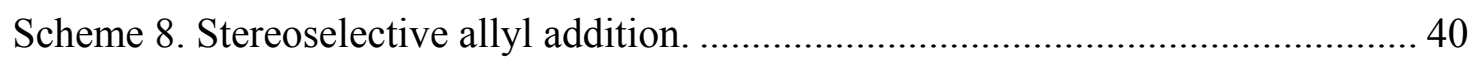

Scheme 9. Anionic oxy-Cope rearrangement,ozonolysis and reductive amination ..... 43

Scheme 10. Michael type cyclization on model stucture ........................................ 44

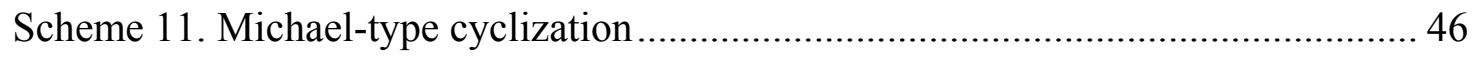

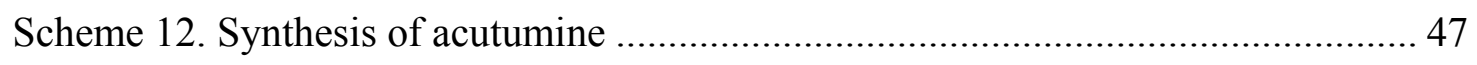

\section{Chapter 5. Conclusion and Future Work}

Scheme 1. Radical-polar crossover reactions on different substrate .........................53

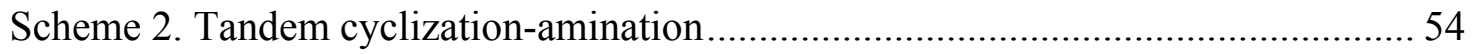




\section{LIST OF TABLES}

\section{Chapter 4. Radical-polar Cyclization and the Total synthesis of Acutumine}

Table 1. Yield and selectivity of radical-polar crossover reaction ........................... 35

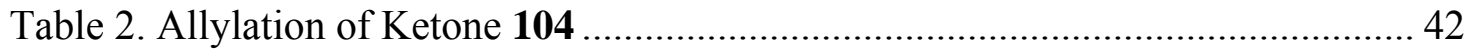

Table 3. Development of cyclization conditions in model system ............................ 45 


\section{Chapter 1. Introduction}

\subsection{Background}

Alkaloids are a group of natural products with at least one basic nitrogen atom. Many of them are from plants and have strong bioactivity. ${ }^{1}$ Since morphine (2, Figure 1), the first active member of this family was discovered by Sertürner in 1817, alkaloids have attracted extensive attention from organic chemists not only for their strong pharmacological effects, but also for the intriguing structures which have inspired the development of several novel reactions, catalysts, and techniques.

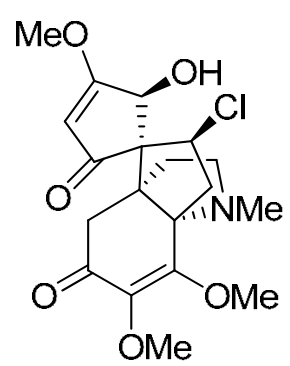

1

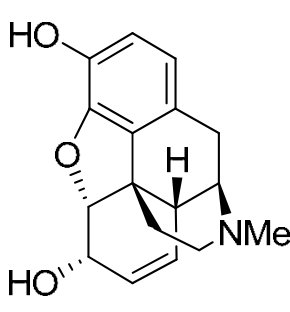

2

Figure 1. Acutumine (1) and Morphine (2)

\subsection{Discovery and Bioactivity}

The tetracyclic alkaloid acutumine (1, Figure 1) is found to be the major constituent of the vines Menispermum dauricum, ${ }^{2}$ Sinomenium acutum, ${ }^{3}$ and 
Menispermum canadense. ${ }^{4}$ Menispermum dauricum is a widespread plant in China, and its rhizome is a traditional Chinese medicine which is officially documented in the Chinese Pharmacopoeia as an analgesic and antipyretic agent. ${ }^{5}$ It was reported that acutumine possesses selective T-cell cytotoxicity by Yu et al. in $2002 .{ }^{6}$ Additionally, the antiamnesic properties of $\mathbf{1}$ were also described in Qin's patent in 2004. These data were based on experiments with animal models. ${ }^{7}$

Acutumine 1 was isolated by K. Goto and H. Sudzuki in $1929,{ }^{2}$ but the structure and the stereochemistry were not determined until thirty-eight years later by Tomita and coworkers through X-ray crystallographic studies in $1967 .{ }^{4,8,9}$ This benzylisoquinoline alkaloid is characterized by a propellane-like [4.3.3.0] fused tricycle, a spirocycle, and a neopentylic secondary chloride, which bears some structural resemblance to the morphine (2) alkaloids. Several derivatives such as dechlorodauricumine 3 , dauricumine $4^{10}$, dauricumidine $5^{11}$, dechloroacutumine 6, and acutumidine 7 (Figure 2) are also isolated from the same plant and reported to share similar core structures. Recently Sugimoto et al. proposed a biosynthetic relationship among those similar alkaloids, in which dechlorodauricumine $\mathbf{3}$ is the original precursor. Then the chloride atom was installed regioselectively and stereoselectively with the help of enzyme(s) to get dauricumine 4 , which could lead to acutumine $\mathbf{1}$ by epimerization. Catalyzed by same or similar chlorination enzyme(s), acutumine $\mathbf{1}$ could also be formed by dechloroacutumine (6), although the detailed mechanisms are still under investigation. 


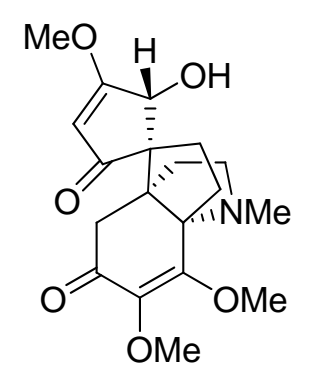

Dechlorodauricumine (3)

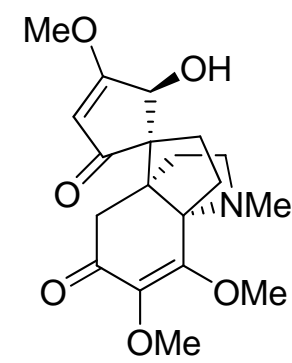

Dechloroacutumine (6)

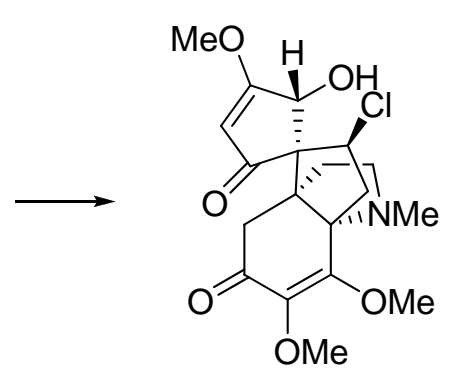

Dauricumine (4)
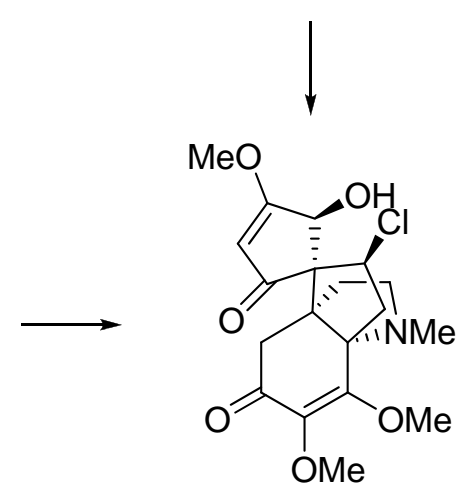

Acutumine (1)

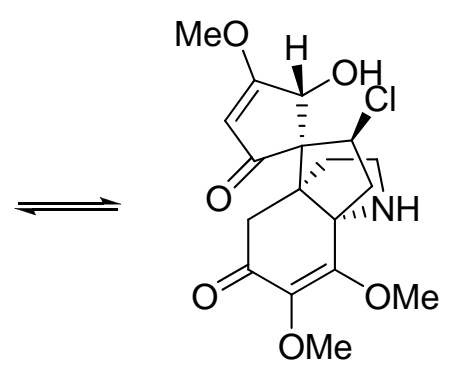

Dauricumidine (5)

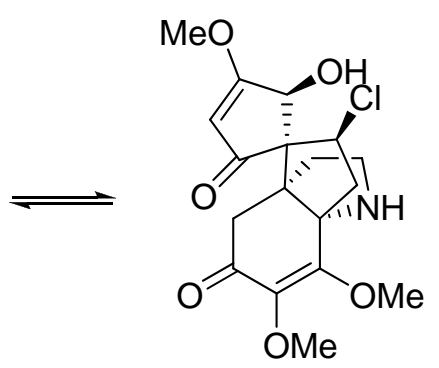

Acutumidine (7)

Figure 2. Proposed biosynthetic relationship among acutumine alkaloids

\subsection{Biosynthesis}

Barton and co-workers proposed an idea for the biosysnthesis of $\mathbf{1}$ in $1968,{ }^{12}$ in which spirodienone 8 (Scheme 1) undergoes a double epoxidation follow by a hydrolytic Favorskii-type rearrangement to furnish acutumine. 

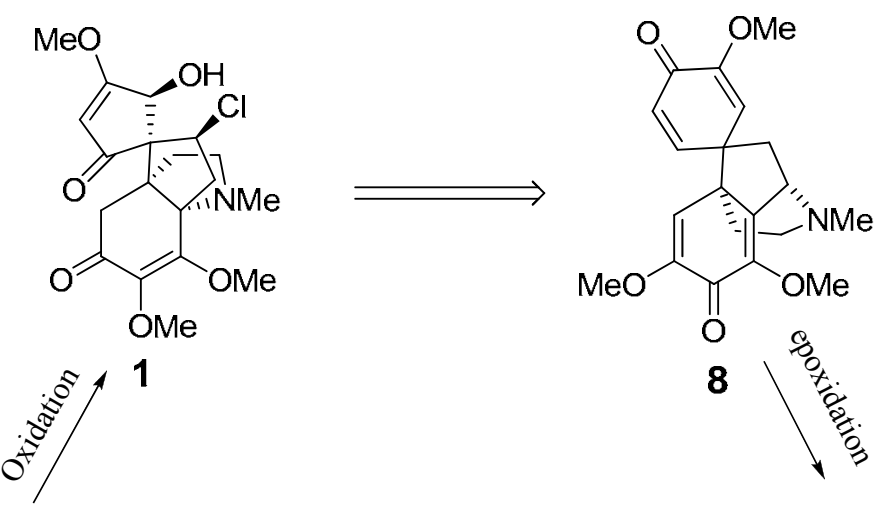

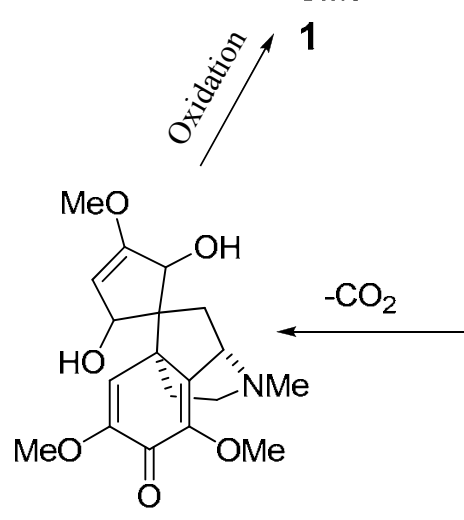

11

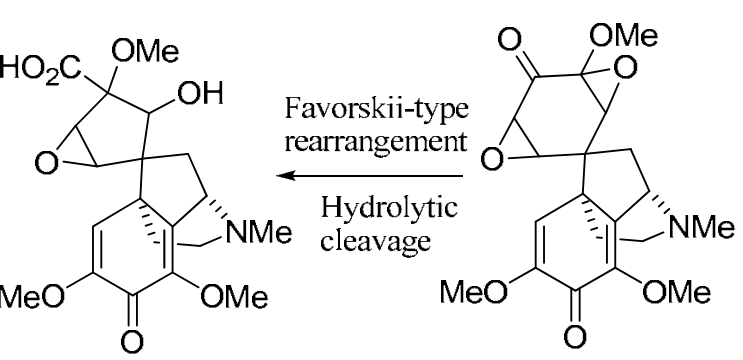

10

9

Scheme 1. Barton's proposal for the biosynthesis of acutumine (1)

However, in 1984, Matoba and co-workers tested the diepoxidation on a simpler subsrate (Scheme 2). ${ }^{13}$ They reported that $m$-CPBA can only provid monoepoxidation product while over-oxidation lead to unexpected Bayer-Villiger rearrangement. Wipf and co-workers confirmed this recently and proposed an oxidative rearrangement methodology of alkyl enol ethers to lactone and spiroketal ester based on this discovery (Scheme 2). ${ }^{14}$ 


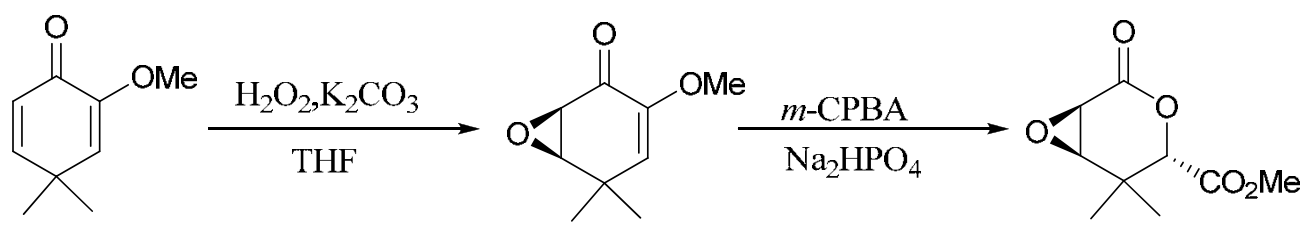

12

13

14

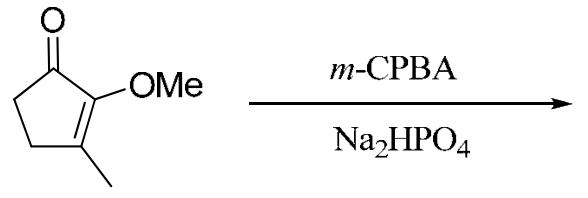

15

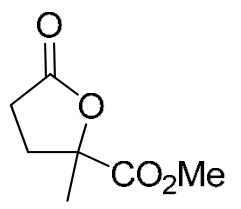

16
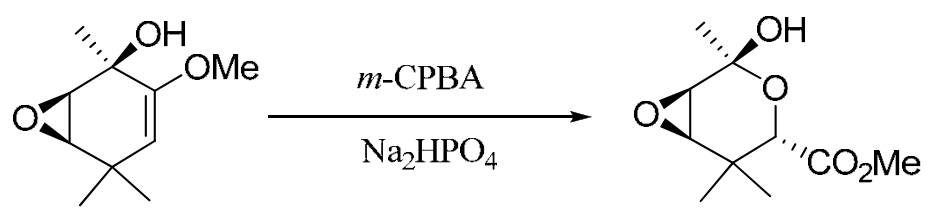

17

18

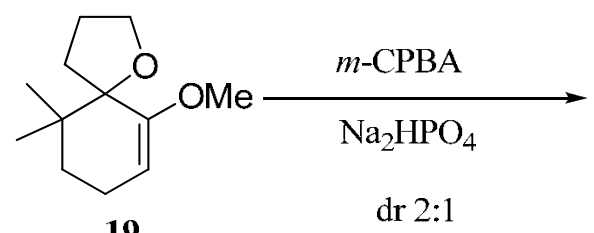

19

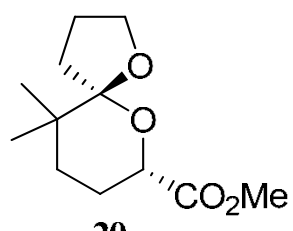

20

Scheme 2. Epoxidation lead to formation of lactone or spiro keto ester

Wipf also proposed a new strategy on the basis of Barton's proposal in 2007, in which tricarbonyl tyrosine dimer 21 (Scheme 3) undergoes an oxidation and benzilic acid rearrangement, followed by decarboxylation to give the cyclopentanone subunit. 


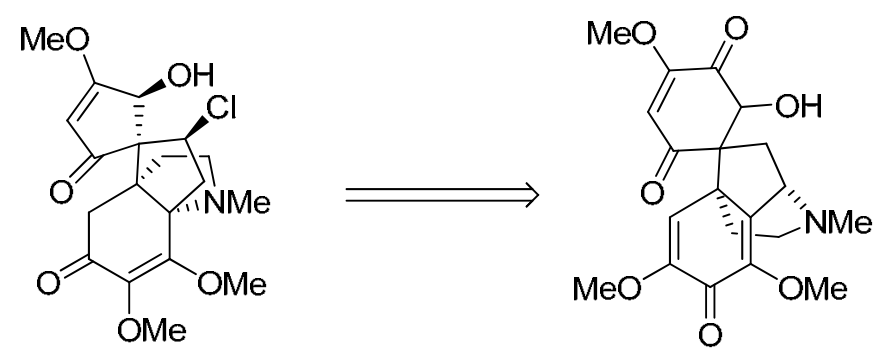

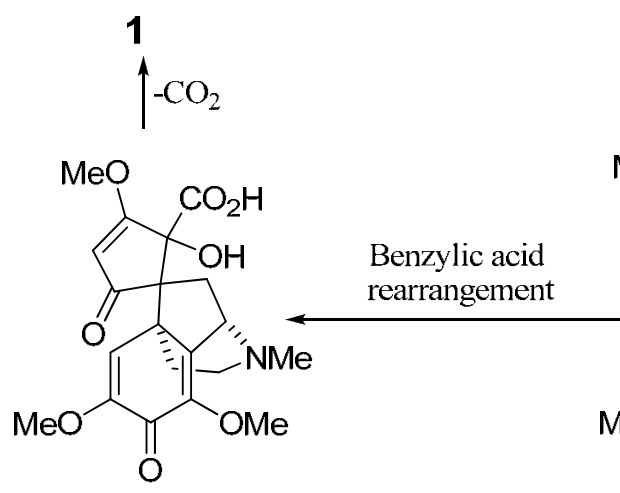

23
21

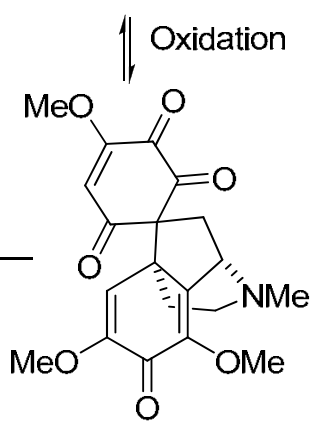

22

Scheme 3. Wipf's modified proposal for the biosynthesis of acutumine (1)

\subsection{Total Synthesis}

The chloride of acutumine resides in the cyclopentane ring along with three contiguous quaternary stereocenters, two of which are all carbon quaternary centers. Forming quaternary stereocenters is a major challenge in organic synthesis. Forming adjacent ones poses an even more significant hurdle because of the extreme steric hindrance. So this unique, chlorine-containing alkaloid has never been synthesized in the eighty years after its discovery. Several hasubanan alkaloid syntheses, which share the same propellane [4.4.3.0] core structure, have been reported by our group ${ }^{15,16}$ and Kobayashi ${ }^{17}$ recently (Figure 3 ). 


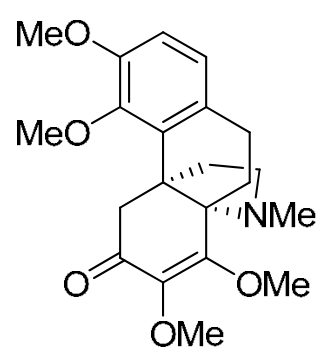

24

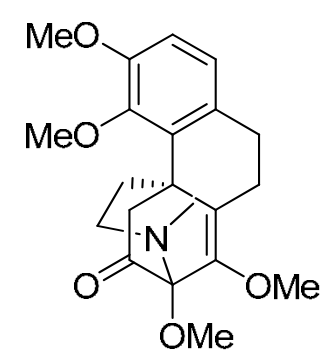

25

Figure 3. Hasubanonine (24) and isohasubanonine (25)

In 2007, Sorensen and co-workers disclosed the preparation of the propellane-like [4.3.3.0] fused tricyclic core of acutumine by a short synthesis, which consisted of a series of remarkable carbonyl chemistry reactions including intromolecular Michael reaction and Dieckmann-like cyclization (Scheme 4). ${ }^{5}$ Despite this progress, a total synthesis has never been reported before 2009.<smiles>COC(=O)C1NCCC1=O</smiles>

26

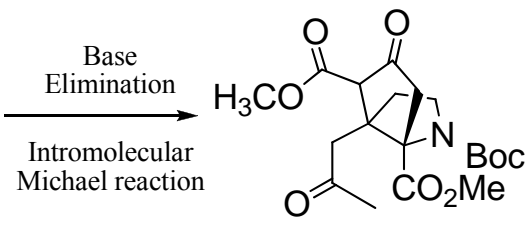

28

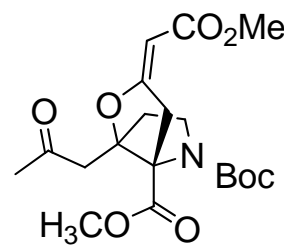

27

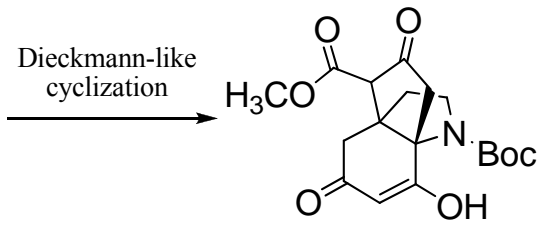

29

Scheme 4. Sorensen's synthesis of tricyclic core structure of Acutumine (1)

In 2005, Matthew D. Reeder in our group synthesized tricyclic compound $\mathbf{2 8},{ }^{18}$ representative of the core of acutumine, in which he developed a strategy for the construction of an all-carbon quaternary center and an adjacent amine-bearing quaternary 
carbon that relies on an anionic oxy-Cope rearrangement followed by a Lewis acid mediated Michael-type cyclization (Scheme 5).

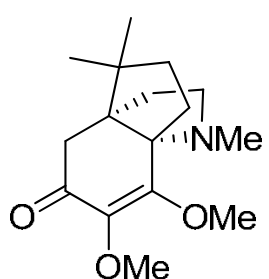

30

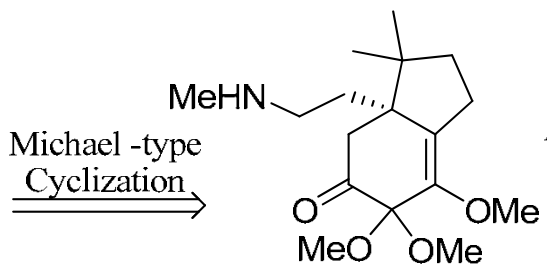

31

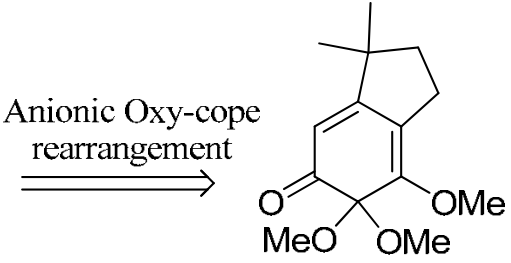

32

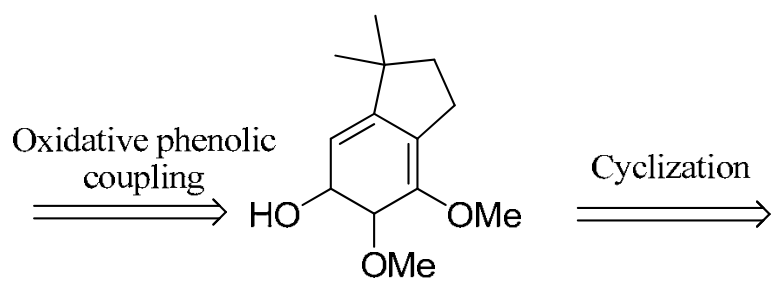

33<smiles>COc1ccc(/C=C/C(=O)O)c(OC)c1OC</smiles>

34

Scheme 5. Reeder's tricycle core structure synthesis

Reeder's work was a major step towards the total synthesis. We then focused on developing a synthesis of the spirocycle core structure first and then applying Reeder's chemistry to the total synthesis. Key to our successful total synthesis was the novel radical-polar crossover reaction (Scheme 6). ${ }^{19}$

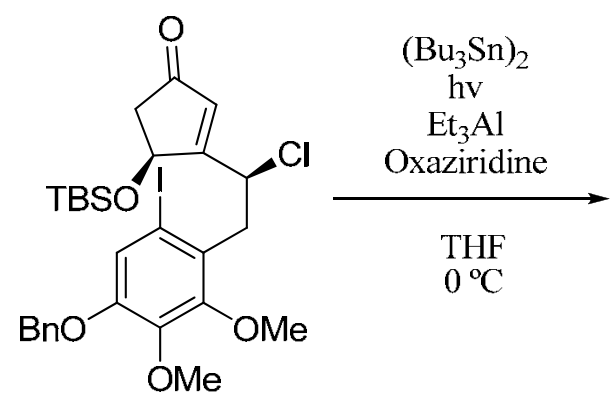

35<smiles>COc1cc2c(c(OC)c1OC)CC(Cl)C2C(O)CC(=O)O</smiles>

36

Scheme 6. Radical-polar crossover reaction

Details of our work applying this methodology to the total synthesis of acutumine will be provided in the following chapters. 


\subsection{References}

1. Hesse, M. Alkaloids. 1 ed.; Wiley-VCH: 2007; p 400.

2. Goto, K.; Sudzuki, H. Bull. Chem. Soc. Japan. 1929, 4 , 220.

3. Doskotch, R. W.; Knapp, J. E. Lloydia 1971, 34, 292

4. Tomita, M.; Okamoto, Y.; Kikuchi, T.; Osaki, K.; Nishikawa, M.; Kamiya, K.; Sasaki, Y.; Matoba, K.; Goto, K. Tetrahedron Lett. 1967, 25, 2421.

5. $\quad$ Moreau, R. J.; Sorensen, E. J. Tetrahedron 2007, 63, 6446.

6. Yu, B. W.; Chen, J. Y.; Wang, Y. P.; Cheng, K. F.; Li, X. Y.; Qin, G. W. Phytochemistry 2002, 61, 439.

7. Qin, G. W.; Tang, X. C.; Lestage, P.; Caignard, D. H.; Renard, P. PCT Int. Appl. 2003, WO 2004000815.

8. Goto, K.; Tomita, M.; Okamoto, Y.; Sasaki, Y.; Matoba, K. Proc. Jpn. Acad. 1966, 42, 1181.

9. Goto, K.; Tomita, M.; Okamoto, Y.; Kikuchi, T.; Osaki, K.; Nishikawa, M.; Kamiya, K.; Sasaki, Y.; Matoba, K. Proc. Jpn. Acad., 1967, 43, 499.

10. Sugimoto, Y.; Babiker, H. A. A.; Saisho, T.; Furumoto, T.; Inanaga, S.; Kato, M. J. Org. Chem. 2001, 66, 3299.

11. Babiker, H. A. A.; Sugimoto, Y.; Saisho, T.; Inanaga, S. Phytochemistry. 1999, 50, 775.

12. Barton, D. H. R.; Kirby, A. J.; Kirby, G. W. J. Chem. Soc. (C) 1968, 929.

13. Matoba, K.; Karibe, N.; Yamazaki, T. Chem. Pharm. Bull. 1984, 32, 2639.

14. Waller, D. L.; Stephenson, C. R. J.; Wipf, P. Org. Biomol. Chem. 2007, 5, 58.

15. Jones, S. B.; He, L. W.; Castle, S. L. Org. Lett. 2006, 8, 3757. 
16. Nielsen, D. K.; Nielsen, L. L.; Jones, S. B.; Toll, L.; Asplund, M. C.; Castle, S. L. J. Org. Chem. 2009, 74, 1187.

17. Nguyen, T. X.; Kobayashi, Y. J. Org. Chem. 2008, 73, 5536.

18. Reeder, M. D.; Srikanth, G. S.; Jones, S. B.; Castle, S. L. Org. Lett. 2005, 7, 1089.

19. Li, F.; Tartakoff, S. S.; Castle, S. L. J .Am. Chem. Soc. 2009, 131, 6674.

20. Li, F.; Castle, S. L. Org. Lett. 2007, 9, 4033. 


\title{
Chapter 2. Investigation of 5-exo Friedel-Crafts Cyclization
}

\author{
onto An Epoxide
}

\subsection{Targeted Spirocycle Ring}

With the establishement of a route to the propellane-type core of acutumine by Reeder et al, ${ }^{1}$ we needed to construct a spirocyclic substrate to test this strategy in the total synthesis (Figure 1). My work on the project began at this point.

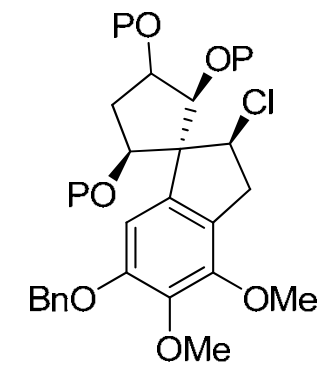

37

$\mathrm{P}=$ protection group

Figure 1. Targeted spirocycle ring

The fused spirocycle is characterized by an all carbon quaternary stereocenter and a neopentylic secondary chloride. As mentioned in the introduction, building an all carbon quaternary stereocenter is still a big challenge in synthetic chemistry. Moreover, the stability of the chloride is another concern. 


\subsection{Retrosynthesis}

Our first retrosynthesis of the acutumine spirocycle is outlined in Scheme 1. Exposure of epoxide 39 to Lewis acids or Brønsted acids should result in formation of the desired spirocycle 38 via regioselective 5-exo Friedel-Crafts cyclization. ${ }^{2}$ Sharpless epoxidation of allyl chloride 40 could afford epoxide 39 directly. Allyl alcohol $\mathbf{4 1}$ could be provided after coupling with Weinreb amide 43 and vinyl iodide 44 followed by stereoselective reduction of $\mathbf{4 2}$. Though we realized the stability of the chloride in subsequent reactions might be a challenging problem, we hoped that the neighboring quaternary carbon center would shield this sensitive group from undesired reactions. Also, we hoped to obtain data about the stability of alkyl chlorides in various reactions. 


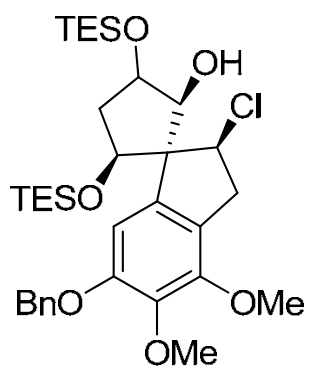

38

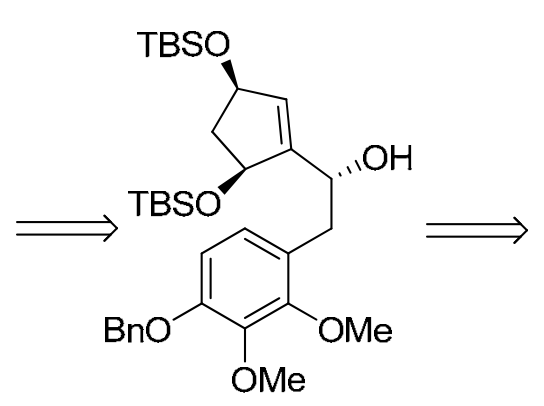

41

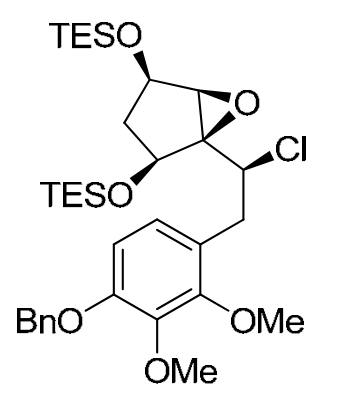

39

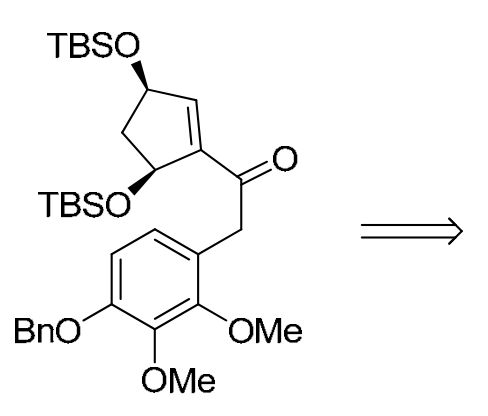

42

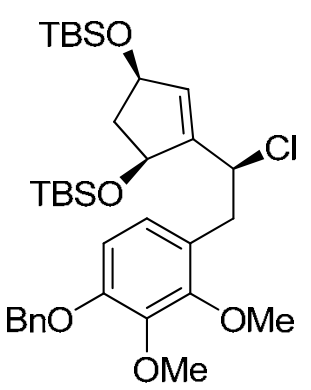

40<smiles>COc1c(O)ccc(CC(=O)N(C)OC)c1OC</smiles>

43

Scheme 1. Retrosynthesis of spirocycle

\subsection{Synthesis of Vinyl Iodide 44}

In order to achieve our total synthesis, as outlined in Scheme 1, we needed to prepare coupling partners 43 and $\mathbf{4 4}$. To obtain enantiopure vinyl iodide 44 , we started from dicyclopentadiene $\mathbf{4 5}$ and followed the procedure of Deardoff and co-workers. ${ }^{3,4}$ Dicyclopentadiene is a white solid at room temperature, but it could be melted at $32{ }^{\circ} \mathrm{C}$ and broken down to cyclopentadiene 46 through a retro Diels-Alder reaction when heated over $240^{\circ} \mathrm{C}$. Cyclopentadiene 46 readily dimerizes to form its precursor $\mathbf{4 5}$ at room 
temperature. So, the following epoxidation was conducted quickly to provide stable epoxide 47. Treatment of $\mathbf{4 7}$ with tetrakis(triphenylphosphine)palladium afforded racemic cis-monoacetate $\mathbf{4 8} .{ }^{3}$ Enantiopure $\mathbf{4 8}$ would be obtained following acetylation and electric eel acetylcholinesterase (EEAC) mediated desymmetrization. ${ }^{4}$ The exchange of protecting group from $\mathbf{4 8}$ to $\mathbf{5 1}$ was previously reported by Myers. ${ }^{5}$ Conversion of 51 to 54 also followed Myers' strategy. Subsequent $\alpha$-iodination and Luche reduction ${ }^{6}$ of 54 gave 56 and followed the approach reported for different substrates by Johnson. ${ }^{7}$

Silylation of 56 afforded enantiomerically pure vinyl iodide $\mathbf{4 4}$.
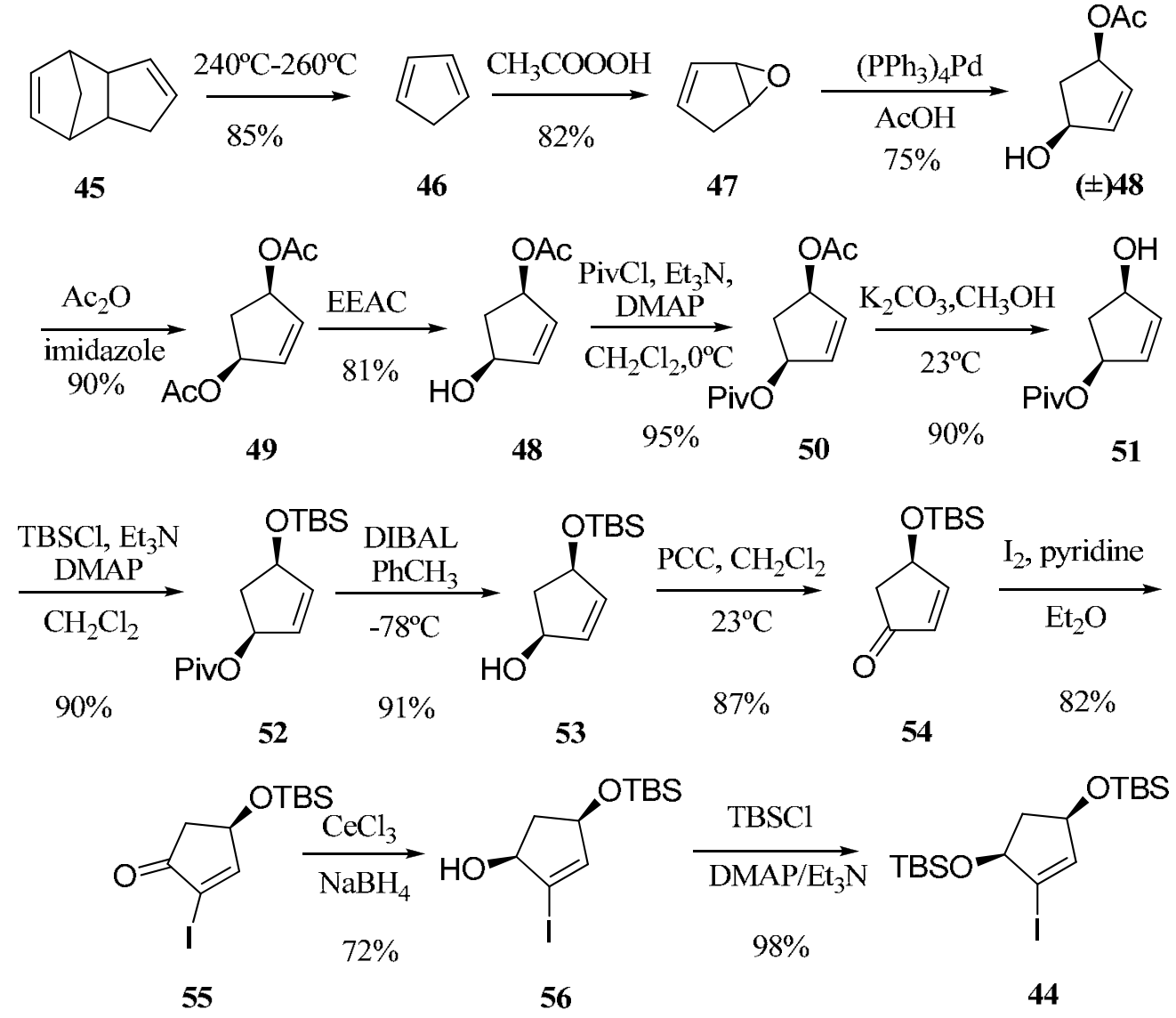

Scheme 2. Synthesis of vinyl iodide 44 


\subsection{Synthesis of Weinreb amide 43}

To obtain the Weinreb amide 43, 4-hydroxy- 2,3-dimethoxybenzaldehyde 58 was chosen as the starting material. However, it is difficult to produce this benzaldehyde efficiently and conveniently. Initially, the demethoxylation of 2,3,4-trimethoxyaldehyde 57 (Scheme 3) was tested. At this stage, two selective demethylation reagents were investigated $\left(\mathrm{BBr}_{3}\right.$ and $\left.\mathrm{NaSEt}\right)$. Unfortunately, we obtained the undesired regiosisomer 59 as the major product. NaS-t-Bu was also evalutated as the demethylation reagent. Some of the desired isomer $\mathbf{5 8}$ was formed. The ratio between $\mathbf{5 8}$ and $\mathbf{5 9}$ was 1:9-1:10. Obviously this was not synthetically useful.

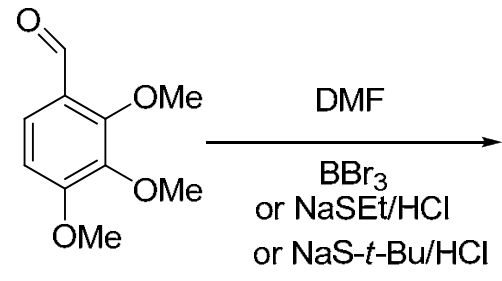

57

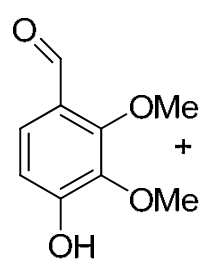

58

$9 \%$<smiles>COc1ccc(C=O)c(O)c1OC</smiles>

59

$72 \%$

Scheme 3. Demethylation of trimethoxy benzaldehyde

When treated with chloroform and $\mathrm{NaOH}$ under reflux conditions, 2,3-

dimethoxybenzaldehyde $\mathbf{6 0}$ can be converted to $58 .{ }^{8}$ Though the yield is poor and not very reproducible (15-30\%), it was the best way I found to make the benzaldehyde. Compound $\mathbf{6 1}$ could be formed in 37\% (in two steps from 60) by treating compound $\mathbf{5 8}$ with benzylbromide (Scheme 4). 


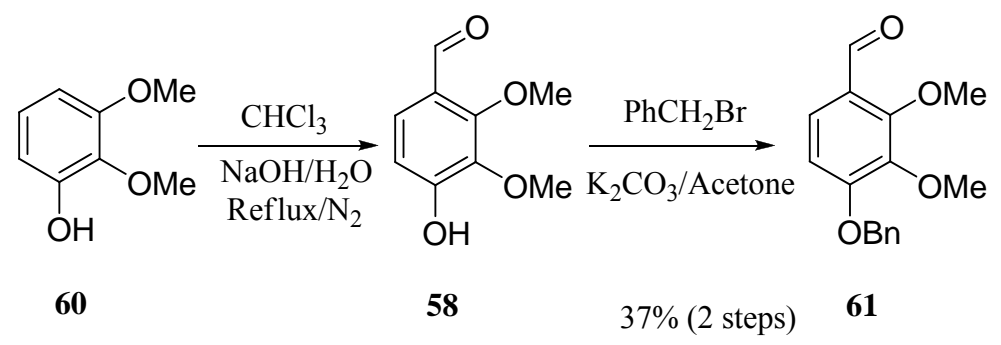

Scheme 4. Synthesis of benzaldehyde 61

With 61 in hand, two protocols were investigated for converting 61 to 63; the first of which involved formation of epoxide $\mathbf{6 2}$ followed by indium-chloride promoted rearrangement (Scheme 5). ${ }^{9}$

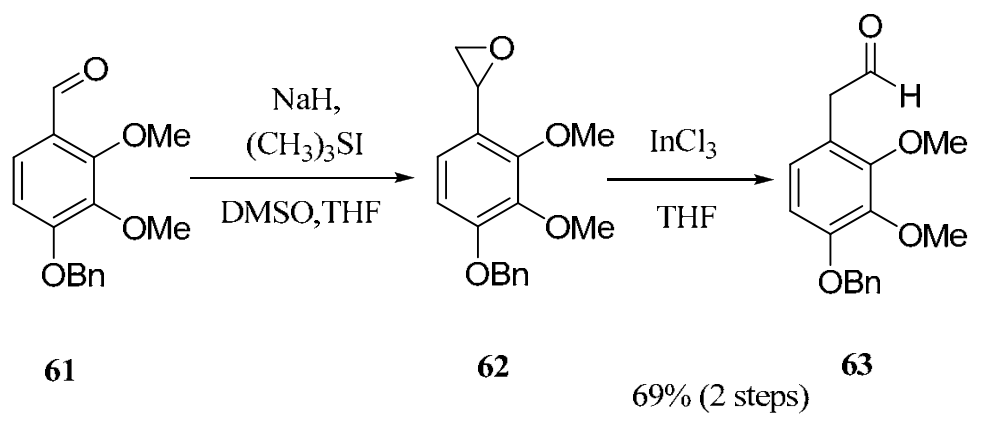

Scheme 5. Synthesis of homologous benzaldehyde 63 through sulfur ylide

The second approach involved Wittig reaction of aldehyde $\mathbf{6 1}$ to give enol ether 64, followed by hydrolysis to give 63. ${ }^{10,11}$ Eventually, this route was chosen because it was more convenient and offered higher yields (Scheme 6). 
<smiles>COc1ccc(C=O)c(OC)c1OC</smiles>

61

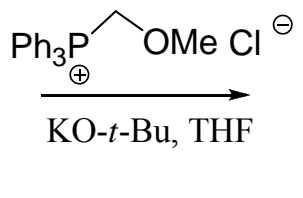

64<smiles>COc1c(CC=O)cc(Cl)c(OCc2ccccc2)c1OC</smiles>

63

$$
75 \% \text { (2 steps) }
$$

Scheme 6. Synthesis of homologous benzaldehyde 63 through Wittig reaction

Conversion of 63 to 65 via Jones oxidation ${ }^{12}$ followed by amidation of an intermediate mixed anhydride gave Weinreb amide 43 in 78\% yield (Scheme 7). ${ }^{13}$<smiles>COc1c(CC=O)ccc(OCc2ccccc2)c1OCC(=O)O</smiles>

63<smiles>COc1c(CC(=O)O)ccc(OCc2ccccc2)c1OC</smiles>

65<smiles>COc1c(CC(=O)N(C)C)ccc(OCc2ccccc2)c1OC</smiles>

43

$78 \%$ (3 steps)

Scheme 7. Synthesis of the Weinreb amide 43

\subsection{Coupling and Synthesis of Epoxide 67}

With coupling partners $\mathbf{4 3}$ and $\mathbf{4 4}$ in hand, different coupling conditions including $n$-BuLi, $t$-BuLi, PhLi and $\mathrm{CH}_{3} \mathrm{MgBr}$ were evaluated. ${ }^{14}$ As it turned out, t-BuLi gave the best yield though it is very sensitive to moisture (Scheme 8). Stereoselective reduction of 42 has been performed by three kinds of catalyst: CBS (Corey-Bakshi-Shibata), ${ }^{15}$ BINAL-H. ${ }^{16,17}$ and Tsdpen reduction. ${ }^{18}$ The best yield is from CBS with $90 \%$ yield and $57 \%$ de, while BINAL-H provided $80 \%$ yield and $48 \%$ de; Tsdpen provided $59 \%$ yield 
and $51 \%$ de. The configuration of the newly formed stereocenter of $\mathbf{4 1}$ was assigned by Mosher's method using R-MTPA. ${ }^{19}$ The hydroxyl group of $\mathbf{4 1}$ was replaced by chlorine via treatment with $\mathrm{NCS} /\left(\mathrm{CH}_{3}\right)_{2} \mathrm{~S}$ to give $\mathbf{4 0}{ }^{20}$ Both silyl ether groups were removed by TBAF to give 66. The alcohol-directed epoxidation ${ }^{21}$ was performed under Sharpless conditions with high yields and diastereoselectivity. 
<smiles>COc1c(CC(=O)N(C)OC)ccc(OCc2ccccc2)c1OC</smiles>

43

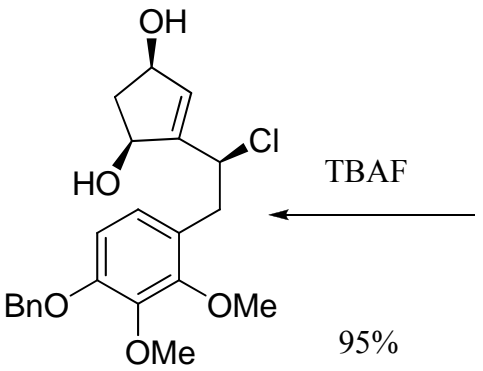

66

$\mathrm{t}-\mathrm{BuOOH}$

$\mathrm{VO}(\mathrm{acac})_{2}$

$79 \%$ as single isomer<smiles>COc1c(C[C@@H](Cl)[C@]23O[C@H]2[C@H](O)C[C@H]3O)ccc(OCc2ccccc2)c1OC</smiles>

67<smiles>COc1c(CC(=O)C2=C[C@@H]([OH+])C[C@H]2O[SbH3])ccc(OCc2ccccc2)c1OC</smiles>

42

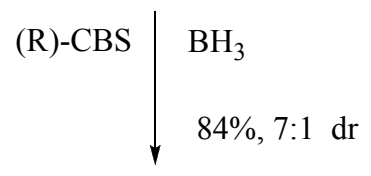<smiles>COc1c(C[C@H](Cl)C2=C[C@@H]([OH+])C[C@H]2O[SbH3])ccc(OCc2ccccc2)c1OC</smiles><smiles>CC(C)(C)C</smiles><smiles>COc1c(C[C@H](O)C2=C[C@@H]([OH+])C[C@H]2O[AsH3])ccc(OCc2ccccc2)c1OC</smiles>

41

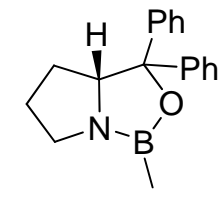

(R)-CBS catalyst

Scheme 8 Coupling and synthesis of epoxide 67 


\subsection{5-exo Friedel-Crafts Cyclization}

After protection of the secdondary hydroxyls of 67, we attempted to install the spirocyclic quarternary center via a Lewis Acid promoted 5-exo cyclization (Scheme 9). Unfortunately, no matter what Lewis or Brønsted acid we used, no desired compound 38 was formed. Instead, the chloride elimination product 68 was obtained. It is obvious that the elimination product is stabilized by conjugation with the aromatic ring and this stabilization makes the secondary chloride too fragile to survive the epoxide opening conditions. As a result, we were forced to develop a new strategy.<smiles>COc1c(CC(Cl)C23OC2[C@H](O)C[C@@H]3O)ccc(OCc2ccccc2)c1OC</smiles>

67

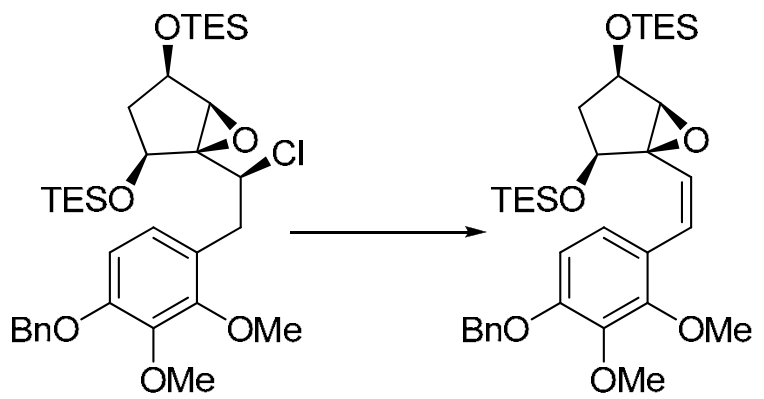

39 68 $\downarrow \begin{gathered}\text { Lewis acid } \\ \downarrow \text { Brønsted acid }\end{gathered}$

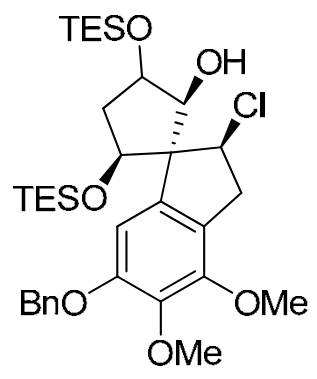

38

Scheme 9. 5-Exo Friedel-Crafts cyclization 


\subsection{References}

1. Reeder, M. D.; Srikanth, G. S.; Jones, S. B. Castle, S. L. Org. Lett. 2005, 7, 1089.

2. $\quad$ Rinner, U.; Siengalewicz, P.; Hudlicky, T. Org. Lett. 2002, 4, 115.

3. Deardorff, D. R.; Linde, R. G.; Martin, A. M.; Shulman, M. J. J. Org. Chem. 1989, $54,2759$.

4. Deardorff, D. R.; Windham, C. Q.; Craney, C. L. Org. Synth. 1996, 73, 25.

5. $\quad$ Myers, A. G.; Hammond, M.; Wu, Y. S. Tetrahedron Lett. 1996, 37, 3083.

6. Luche, J. L.; Rodriguezhahn, L.; Crabbe, P. J. Chem. Soc. Chem. Commun. 1978, 14,601 .

7. Johnson, C. R.; Harikrishnan, L. S.; Golebiowski, A. Tetrahedron Lett. 1994, 35, 7735 .

8. Kurosawa, K.; Ollis, W. D.; Sutherland, I. O.; Gottlieb, O. R.; Deoliveira, A. B. Phytochemistry. 1978, 17, 1389.

9. Ranu, B. C.; Jana, U. J. Org. Chem. 1998, 63, 8212.

10. Moeller, K. D.; Tinao, L. V. J. Am. Chem. Soc. 1992, 114, 1033.

11. Posner, G. H.; Oh, C. H.; Gerena, L.; Milhous, W. K. J. Med. Chem. 1992, 35 , 2459.

12. Bowden, K.; Heilbron, I. M.; Jones, E. R. H.; Weedon, B. C. L. J. Chem. Soc. 1946, 39.

13. Raghuram, T.; Vijaysaradhi, S.; Singh, I.; Singh, J. Synthetic Commun.1999, 29, 3215.

14. Nahm, S.; Weinreb, S. M. Tetrahedron Lett. 1981, 22, 3815.

15. Corey, E. J.; Bakshi, R. K.; Shibata, S. J. Am. Chem. Soc. 1987, 109, 5551. 
16. Noyori, R.; Tomino, I.; Yamada, M.; Nishizawa, M. J. Am. Chem. Soc. 1984, 106, 6717.

17. Noyori, R.; Tomino, I.; Tanimoto, Y.; Nishizawa, M. J. Am. Chem. Soc. 1984, 106, 6709 .

18. Hashiguchi, S.; Fujii, A.; Takehara, J.; Ikariya, T.; Noyori, R. J. Am. Chem. Soc. 1995, 117, 7562 .

19. Dale, J. A.; Dull, D. L.; Mosher, H. S. J. Org. Chem. 1969, 34, 2543.

20. Corey, E. J.; Kim, C. U.; Takeda, M. Tetrahedron Lett. 1972, 42, 4339.

21. Sharpless, K. B.; Verhoeven, T. R. Aldrichimica Acta 1979, 12, 63-74. 


\title{
Chapter 3. Radical Cyclization Route to the Spirocycle of
}

\author{
Acutumine
}

\subsection{Retrosynthesis of Radical Cyclization Route}

The failed Friedel-Crafts cyclization suggested that the secondary chloride might be too fragile to withstand exposure to Lewis and Brønsted acids. Thus a new cyclization strategy was employed. Radical cyclization has shown the strong potency to construct

quaternary carbons, ${ }^{1}$ so a 5-exo-trig radical cyclization strategy was devised to construct the spirocycle (Scheme 1). 


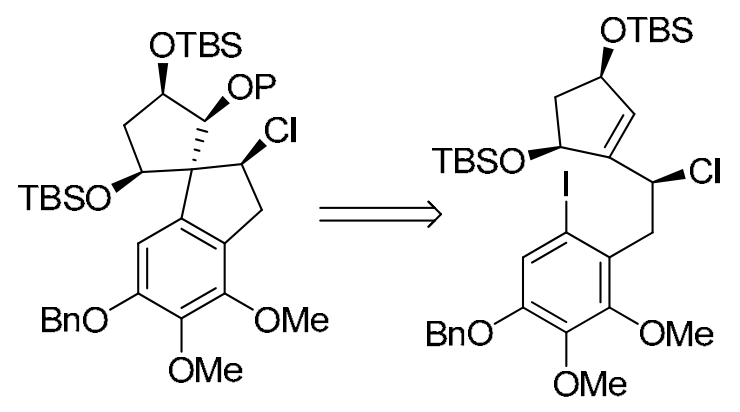

37

$\mathrm{P}=$ protection group

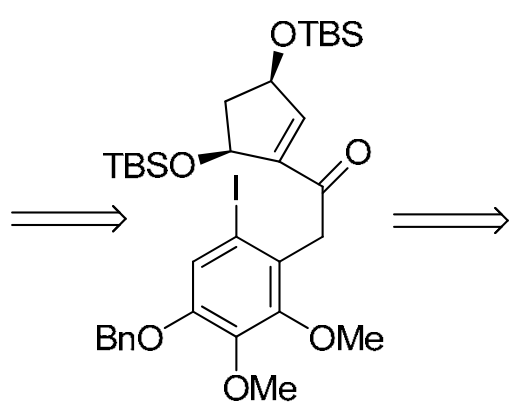

70<smiles>COc1c(OCc2ccccc2)cc(I)c(CC(=O)N(C)C)c1OC</smiles>

71<smiles></smiles>

44

Scheme 1. Retrosynthesis of radical cyclization

\subsection{Synthesis of Iodinated Weinreb Amide 71}

To obtain the proper substrate for the radical cyclization, a similar strategy to the one shown in Chapter 2 was used to prepare coupling partner 71, though a few extra steps to install the iodine atom were required (Scheme 2). Benzaldehyde 61 was nitrated in the ortho position to give $\mathbf{7 2}$, and subsequent reduction and iodination afford iodinated benzaldehyde 74. Though the yield for the iodination was not high, it was the only workable iodination strategy, which had been determined by Jones in his hasubanonine synthesis. ${ }^{2}$ Weinreb amide $\mathbf{7 1}$ was then synthesized according to the same route depicted in Chapter 2. 


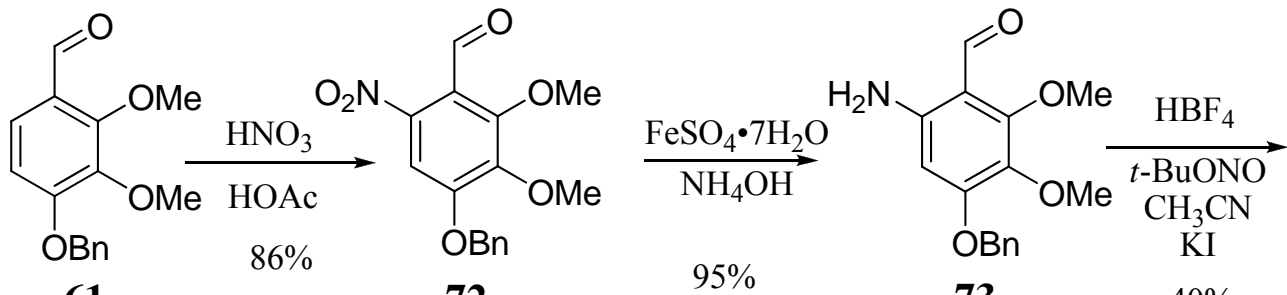

61

72

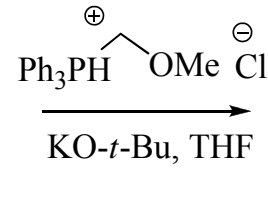

$62 \%$<smiles>CO/C=C/c1c(I)cc(OCc2ccccc2)c(OC)c1OC</smiles>

75<smiles>COc1c(OCc2ccccc2)cc(I)c(CC=O)c1OC</smiles>

76<smiles>COc1c(OCc2ccccc2)cc(I)c(CC(=O)O)c1OC</smiles>

$73 \%$ (2 steps)<smiles>COc1cc(OCc2ccccc2)c(I)c(CC(=O)N(C)C)c1OC</smiles>

$71 \%$

71

Scheme 2. Synthesis of iodinated Weinreb amide $\mathbf{7 1}$

\subsection{Coupling of the Weinreb Amide and Vinyl Iodide}

The attempted coupling of iodinated Weinreb amide 71 with vinyl iodide 44 give low yields. Though this coupling reaction is almost the same as the one utilized in the chemistry discussed in Chapter 2, I obtained very low yields with the same conditions. The iodine atom was apprently cleaved by the organolithium reagent. When we switched to a Grignard reagent, the rich electron density of the cyclopentene ring decreased the $\mathrm{I} / \mathrm{Mg}$-exchange rate (only 5\% vinlymagnisum formed in 7 days at room temperature). 
Knochel and co-workers have reported that increased electron density slows halogenmagnesium exchange. ${ }^{3}$ Knochel also reported that by adding lithium chloride, the reaction rate can be dramatically increased. This technique also worked in our case. When adding lithium chloride as additive and 15 -crown- 5 as the coordinating reagent, the $\mathrm{I} / \mathrm{Mg}$ exchange and the coupling could be finished in one day (Scheme 3). ${ }^{4,5}$<smiles>COc1c(OCc2ccccc2)cc(I)c(CC(=O)N(C)C)c1OC</smiles>

71

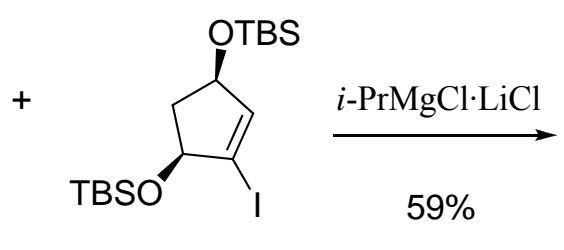

44

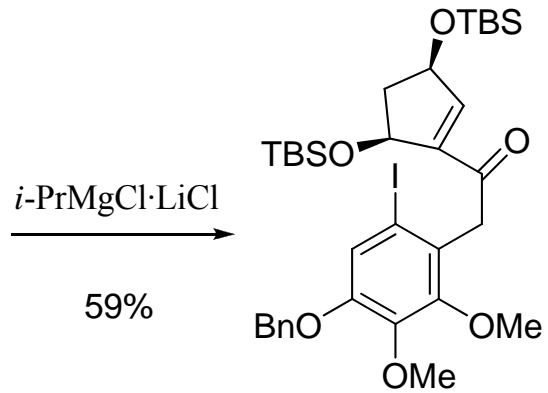

70

Scheme 3. Grignard reagent promoted coupling reaction

\subsection{Stereoselective Reduction and Chlorination}

Under the same conditions as those shown in Chapter 2, iodinated enone $\mathbf{7 0}$ was reduced diastereoselectively and the formed hydroxyl group of $\mathbf{7 8}$ was substituted by chlorine under Corey's conditions (Scheme 4). ${ }^{6}$ By adjusting the equivalents of substrate, oxazaborolidine, and boron hydride (1: $0.2: 1.2)$, we improved the yield (84\%) and de (87\%) of the reduction. The chlorination yield was low, but we did not improve it because at this stage the goal was to get enough substrate to test our new cyclization strategy. 
<smiles>COc1c(OCc2ccccc2)cc(I)c(CC(=O)C2=C[C@@H](O[Sb])C[C@@H]2O[AsH3])c1OC</smiles>

70

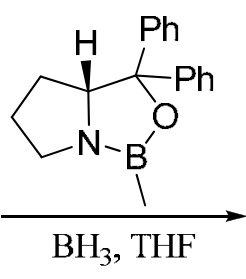

$84 \%, 6.7: 1 \mathrm{dr}$

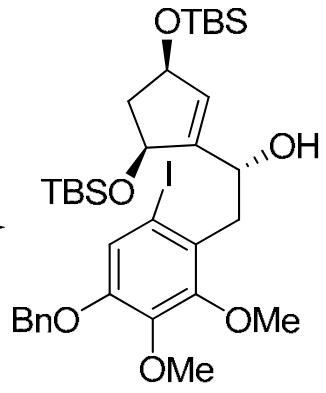

78

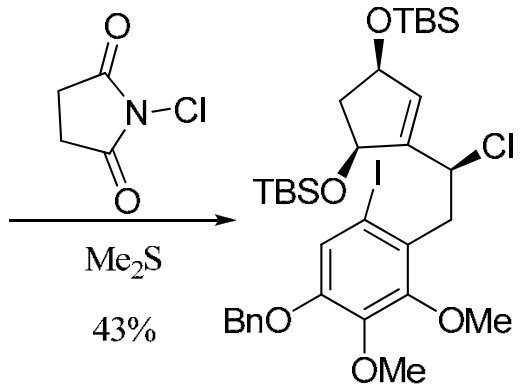

69

Scheme 4. Stereoselective reduction and chlorination

\subsection{Radical Cyclization}

To trigger the radical cyclization, different initiators were examined. To our surprise, treatment of 69 with $\mathrm{Et}_{3} \mathrm{~B} / \mathrm{O}_{2}$ and $\mathrm{Bu}_{3} \mathrm{SnH}^{7}$ afforded 6-endo cyclization product 79 instead of 5-exo. When $\mathrm{TEMPO}^{8}$ was used in place of $\mathrm{Bu}_{3} \mathrm{SnH}$, no cyclization product 80 was detected (Scheme 5). 


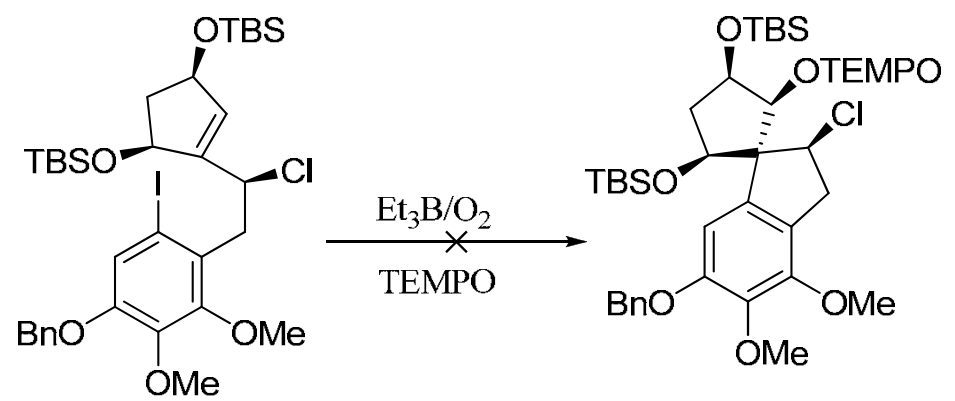

69

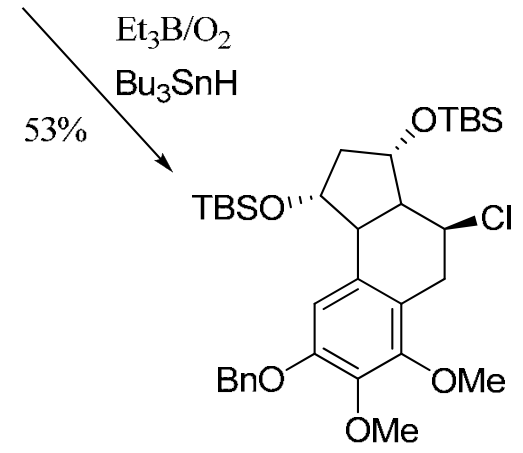

80

79

Scheme 5. Radical cyclization

It is likely that steric hindrance prevents the desired 5-exo cyclization.

Nevertheless, we are happy to find the fact that the sensitive allylic chloride could survive a radical reaction, which inspired us to test the radical-polar crossover reaction. 


\subsection{References}

1. Srikrishna, A.; Jagadeeswar, T. R. J. Am. Chem. Soc. 1996, 64, 6422.

2. Jones, S. B.; He, L. W.; Castle, S. L. Org. Lett. 2006, 8, 3757.

3. Ren, H. J.; Krasovskiy, A.; Knochel, P. Chem. Commun. 2005, 4, 543.

4. Krasovskiy, A.; Knochel, P. Angew. Chem. Int. Ed. 2004, 43, 3333.

5. Krasovskiy, A.; Straub, B. F.; Knochel, P. Angew. Chem. Int. Ed. 2006, 45, 159.

6. $\quad$ Corey, E. J.; Kim, C. U.; Takeda, M. Tetrahedron Lett. 1972, 42, 4339.

7. Orito, K.; Uchiito, S.; Satoh, Y.; Tatsuzawa, T.; Harada, R.; Tokuda, M. Org. Lett. 2000, 2, 307.

8. Engel, P. S.; Pan, L.; Ying, Y. M.; Alemany, L. B. J. Am. Chem. Soc. 2001, 123, 3706. 


\title{
Chapter 4. Radical-Polar Cyclization and the Total synthesis
}

\author{
of Acutumine
}

\subsection{Background of Radical-Polar Crossover Reaction}

In the last thirty years, radical chemistry has received increasing attention from synthetic chemists. ${ }^{1,2}$ The term radical-polar crossover reaction was introduced by Murphy in $1993^{3}$ to describe cascade processes which transition from radical to polar chemistry. These processes can be called cascade radical/ionic reactions. ${ }^{1,2}$ Numerous radical-polar crossover reactions involve radical conjugate addition to an $\alpha, \beta$ unstaturated carbonyl group, then formation of an enolate from an $\alpha$-carbonyl radical. The latter step also helps to propagate the chain process, with the enolate eventually attacking an electrophile. The earliest example, reported by Oshima and coworkers in 1988 , is the intermolecular radical conjugate addition and aldol reactions. ${ }^{4,5}$ Though the potential utility of these reactions are great, there are few examples reported in natural product synthesis. Kunz and co-workers reported a tandem radical conjugate additionenolate hydroxylation in 1991 to install two adjacent stereocenters in one step, one of which is a secondary alcohol (Scheme 1). 
<smiles>[R]C=CC(=O)N1C(=O)OC[C@H]1Br</smiles>
$\mathrm{R}=\mathrm{Me}$, Et, $\mathrm{Pr}, \mathrm{Ph}, \mathrm{p}-\mathrm{CIPh}$ 81

82

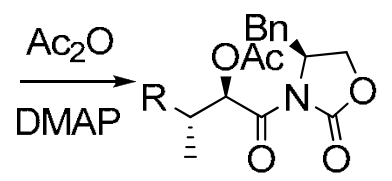

84

Scheme 1. Kunz's radical conjugate addition-enolate hydroxylation

\subsection{Proposed Radical-Polar Crossover Reaction on Our Substrate}

As we revised our route to the acutumine spirocycle, we realized that enone 35 (Scheme 2) would be a suitable substrate for this radical-polar crossover reaction. We need to construct two stereocenters, which include a secondary alcohol and a quaternary carbon. Furthermore, we also need to cyclize to a spirocycle without disturbing the allylic chloride.

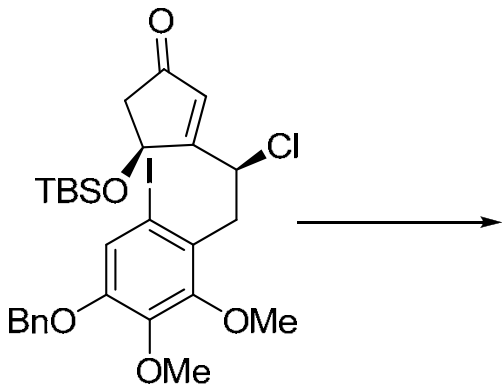

35<smiles>COc1cc2c(c(OC)c1OC)CC(Cl)[C@@]21C(O)CC(=O)C[C@H]1OC(C)(C)C</smiles>

36

Scheme 2 Proposed radical-polar crossover reaction 


\subsection{Synthesis of Vinyl Iodide 90}

To obtain substrate 35, we employed a similar strategy to the one used previously (Chapter 3). Vinyl iodide $\mathbf{9 0}$ was made according to the same procedures by Deardoff, ${ }^{6,7}$ though the two alcohols were differentiated by protecting with different silyl groups (Scheme 3).

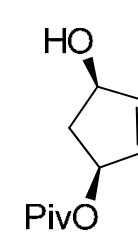

51

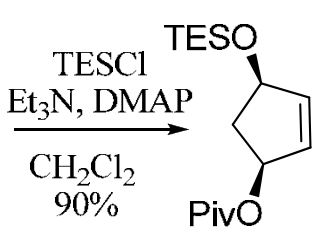

85
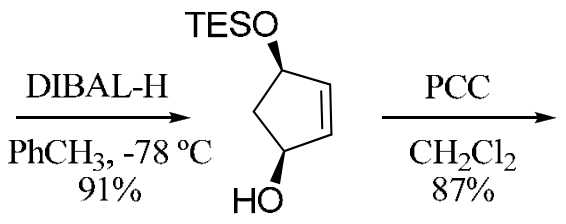

86

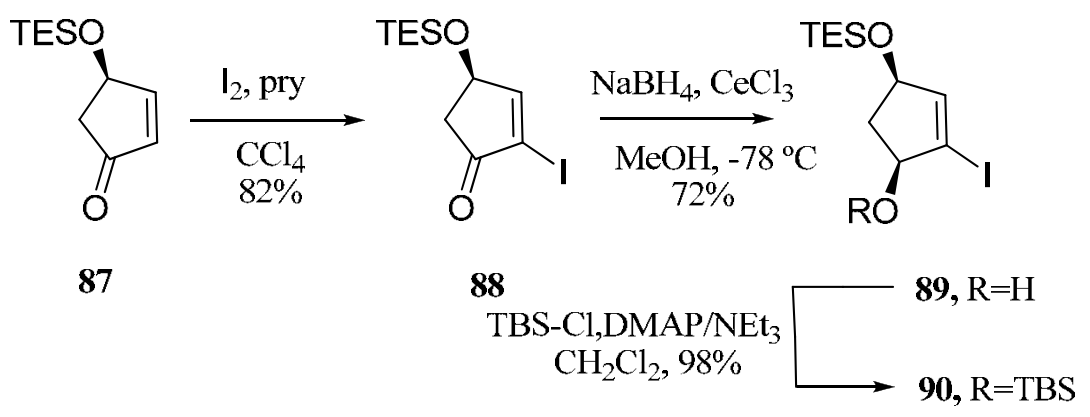

Scheme 3 Synthesis of vinyl iodide 90

\subsection{Synthesis of Cyclization Substrate Enone 35}

By applying the optimized reaction conditions from Chapter 3, coupling of iodinated Weinreb 71 and vinyl iodide 90 afforded enone 91, which was stereoselectively reduced to allyl alcohol 92. As mentioned in Chapter 3, chlorination under Corey's conditions $^{8}$ provided low yields. Consequently, different conditions to install the sensitive chloride were investigated. Most of them, such as $\mathrm{MsCl} / \mathrm{LiCl} /$ collidine, provided 
elimination products. Williams and co-workers met similar problems when synthesizing Stephacidins A, B and Notoamide B. ${ }^{9}$ They solved the problem by switching to $\mathrm{MsCl} / \mathrm{TEA}$, which also worked in our case. The TES group of 93 was selectively cleaved in the presence of the TBS group, and subsequent oxidation afforded enone $\mathbf{3 5}$ directly.

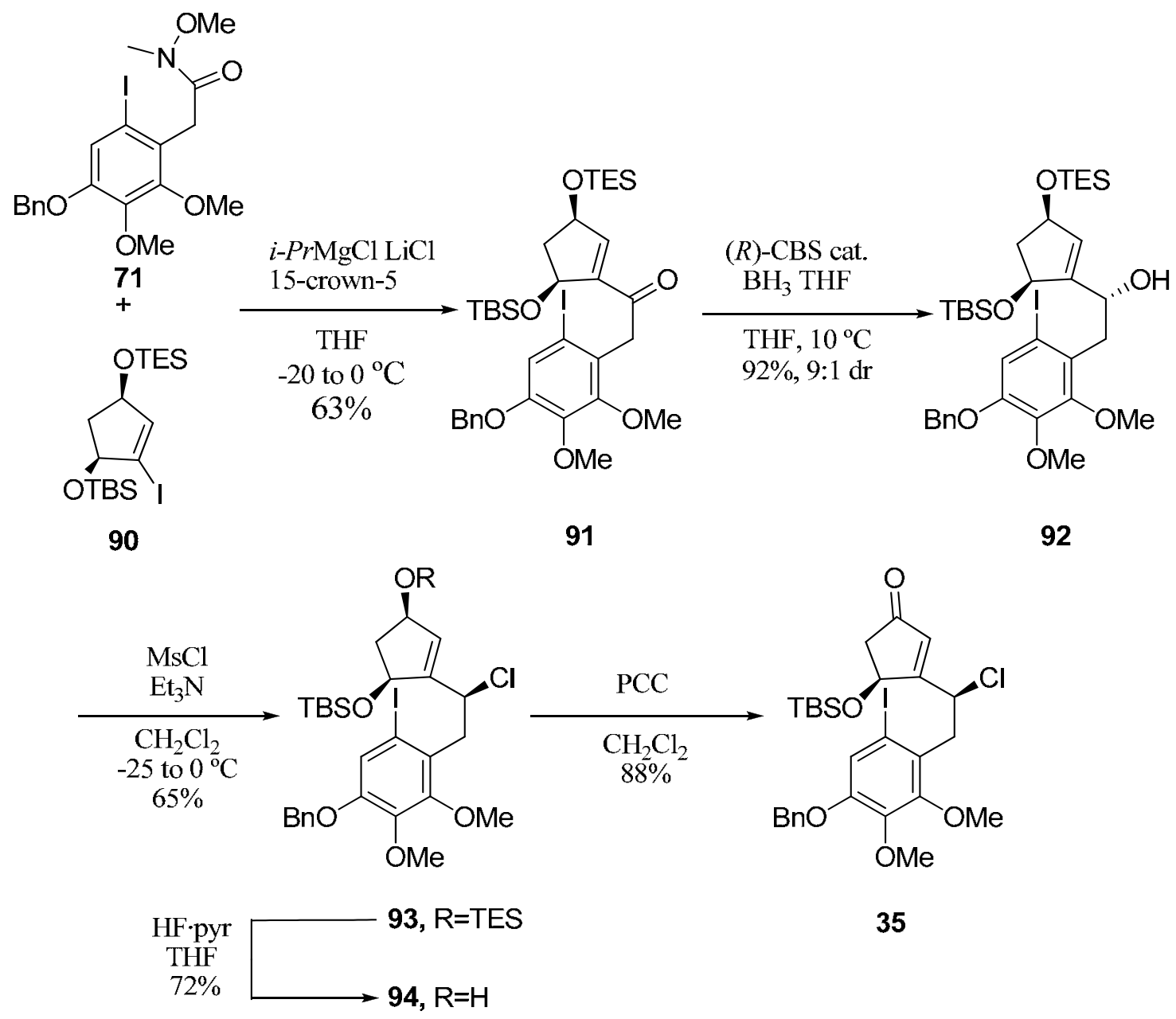

Scheme 4. Synthesis of cyclization substrate enone 35 


\subsection{Radical-Polar Crossover Reaction onto Spirocycle}

To initiate the radical reaction (Scheme 5), we tried different initiators and found that $\mathrm{Et}_{3} \mathrm{~B}$ and $\mathrm{Et}_{2} \mathrm{Zn}$ bring lower yields than $\mathrm{Et}_{3} \mathrm{Al}$. Different enolate hydroxylation reagents and different temperatures were also tested (Table 1).<smiles>COc1c(OCc2ccccc2)cc(I)c(CC(Cl)C2=CC(=O)CC2OC(C)(C)C)c1OC</smiles>

35<smiles>COc1cc2c(c(OC)c1OC)C[C@H](Cl)[C@]21[C@H](I)C(=O)C[C@H]1OC(C)(C)C</smiles>

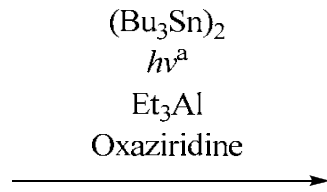

THF $0{ }^{\circ} \mathrm{C}$

$62 \%$

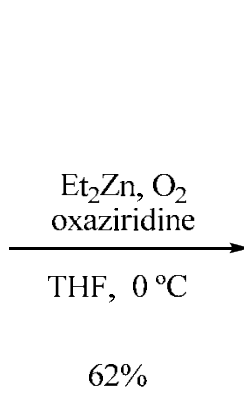<smiles>COc1cc2c(c(OC)c1OC)C[C@H](Cl)[C@]21[C@H](O)C(=O)C[C@H]1O[AsH3]</smiles>

36<smiles>COc1cc2c(c(OC)c1OC)C[C@H](Cl)[C@]21[C@H](O[AsH3])C(=O)C[C@H]1O</smiles>

95<smiles>[R]C1C(=O)C[C@@H](O[AsH3])[C@]12c1cc(OCc3ccccc3)c(OC)c(OC)c1C[C@H]2Cl</smiles>

$95 \mathrm{R}=\mathrm{I}, 7 \%$

$96 \mathrm{R}=\mathrm{H}, 3 \%$

Scheme 5. Radical-polar crossover reaction 


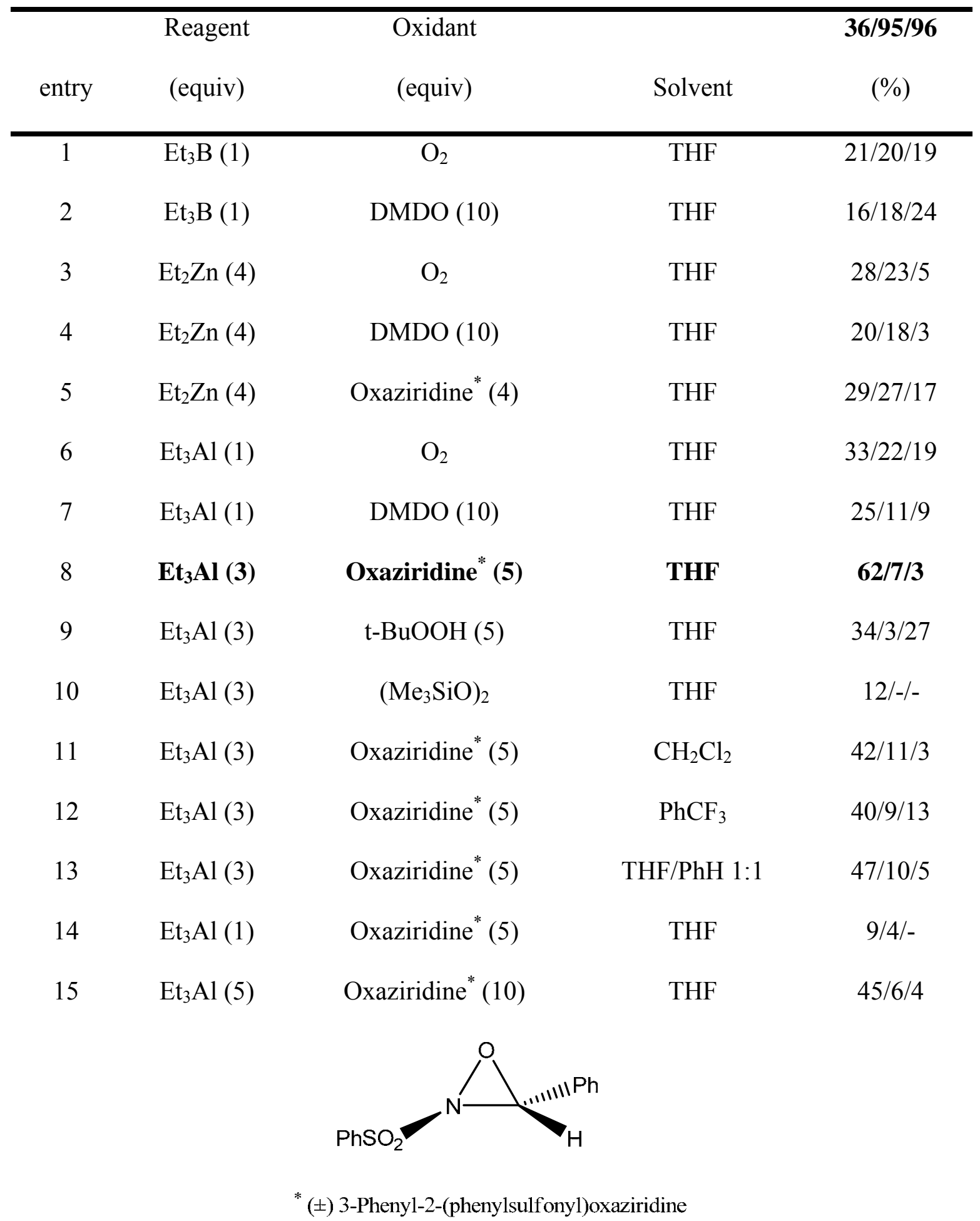

Table 1. Yield and selectivity of radical-polar crossover reaction 
As shown in Table 1, entry 8 leads to the highest yield. In most cases, iodide $\mathbf{9 5}$ and reduced compound 96 were also formed, whereas 96 might come from reduction of $\alpha$-keto radical or enolate. The origin of $\mathbf{9 5}$ is not certain yet. The $\alpha$-keto radical intermediate might be attacked by I. or $\mathrm{I}_{2}$, both of which come from photolytic cleavage of aryl Iodide (vide infra). Another possibility is that the $\alpha$-keto radical or enolate reacts with $\mathrm{Bu}_{3} \mathrm{SnI}$, which is formed by abstraction from vinyl iodide $\mathbf{9 0}$ by tributyltin radical. To improve the yield of this reaction, we tried to explore the possibility for converting iodide 95 into the desired product $\mathbf{3 6}$. We were delighted to find that this transformation could be accomplished under similar condition. $\mathrm{Et}_{2} \mathrm{Zn} / \mathrm{O}_{2}$, together with the oxaziridine, provided $62 \%$ yield, compared to the lower yield $(40 \%)$ of $\mathrm{Et}_{3} \mathrm{Al}$ in this reaction. The material obtained from 95 via this route raised our overall yield of 36 to $66 \%$.

The stereochemistry of $\mathbf{3 6}$ was assigned according to NOE experiments on a $p$ methoxybenzyl ether derivative. The diagnostic correlations are illustrated in Figure 1, and the assignment has been confirmed by the accomplishment of the total synthesis of ()-1 from 36.

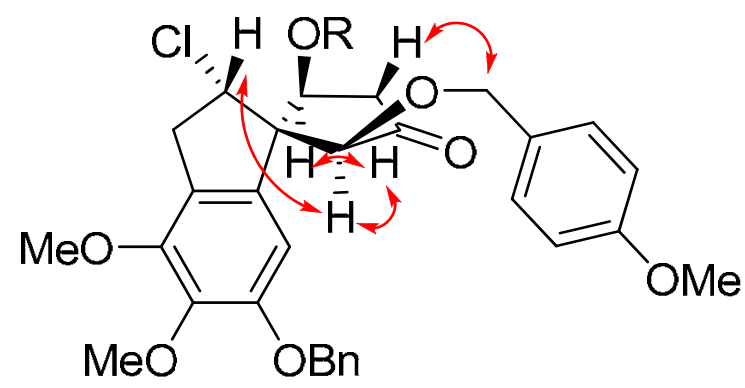

Figure 1. NOE enchancement used to assign the structure of $\mathbf{3 6}$ 
Its interesting that no diastereomers of 36, 95, and 96 were found in this reaction. Though the detailed mechanism of this reaction will require further study, we propose the following mechanism (Scheme 6). The enone subunit of 35 works as a sensitizer by absorbing visible light and transferring energy to the ditin reagent, facilitating its homolytic cleavage. The iodide was abstracted to form an aryl radical and undergo a 5exo-trig cyclization. The aryl radical attacked the enone from the face opposite the bulky adjacent OTBS group. After formation of the spirocycle, the aromatic ring could shield one face of the enolate, causing a stereoselective hydroxylation to produce the desired diastereomer.

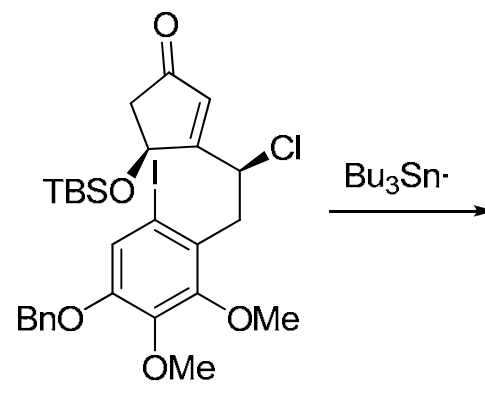

35

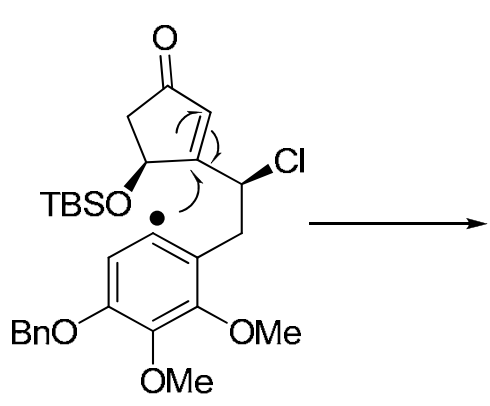

97<smiles>CCN(CC)[Al](CC)CC</smiles>

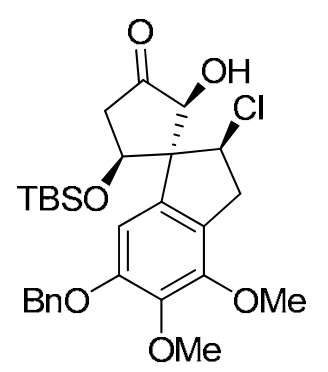

36

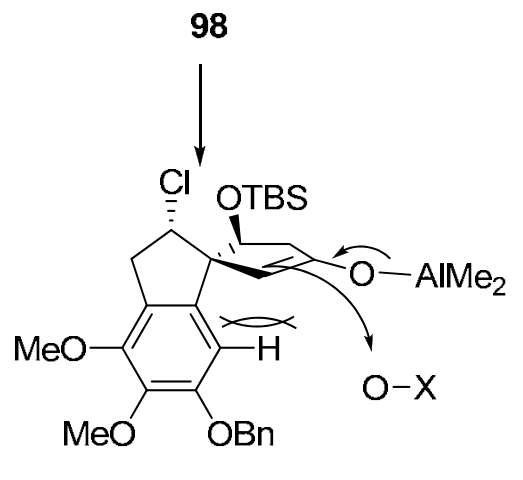

99

Scheme 6 Proposed radical-polar crossover reaction mechanism in our substrate

We also tried $\mathrm{SmI}_{2} / \mathrm{HMPA}$ as radical initiator to generate the aryl radical. Unforturnately, $\alpha$-hydroxy ketone 36 was obtained in low yields as 15\%. Compounds 95, 
96 and other uncharacterized byproducts were also present. This is likely a result of several functional groups' reactivity with $\mathrm{SmI}_{2}$, such as the enone and allylic chloride.

\subsection{Synthesis of Masked $o$-Benzoquinone 104}

To proceed with the total synthesis, $\alpha$-hydroxy ketone 36 was selectively reduced to give diol 100. Different reducing agents were evalutated and L-selectride afforded the largest ratio of diastereoisomers $(9: 1)$, while $\mathrm{NaBH}_{4}$ only provided the products as a 1:1 mixture. Though the newly formed stereocenter would be destroyed in a later step, Lselectride was employed for the convenience in separating and characterization. The less hindered alcohol of $\mathbf{1 0 0}$ was selectively protected as a TBS ether and following hydrogenolysis cleaved the benzyl ether bond to form phenol 101. After removal of the benzyl group by $\mathrm{H}_{2}$, phenolic oxidation of $\mathbf{1 0 2}$ provided masked o-benzoquinone $\mathbf{1 0 3}$, and the remaining alcohol was protected as a benzyl ether. 


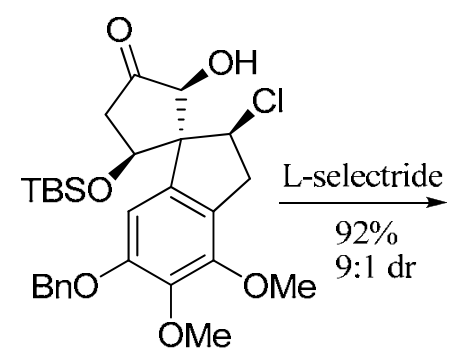

36

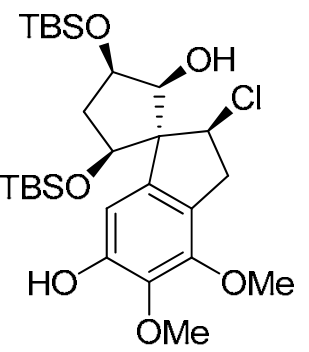

102

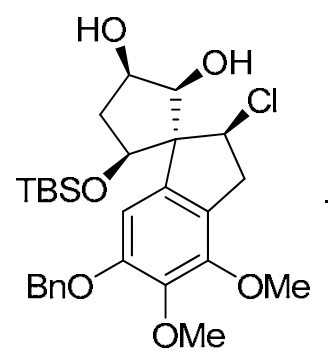

100

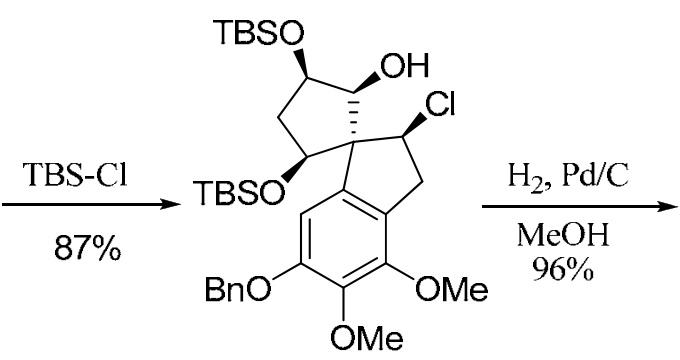

101

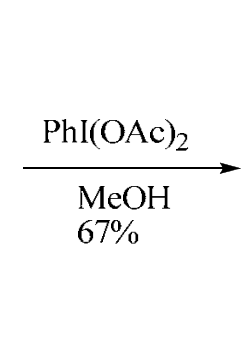

(

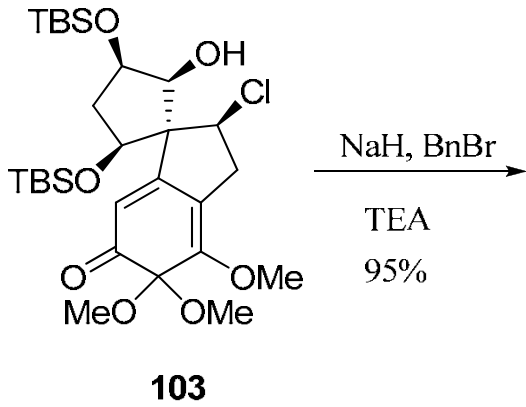

103

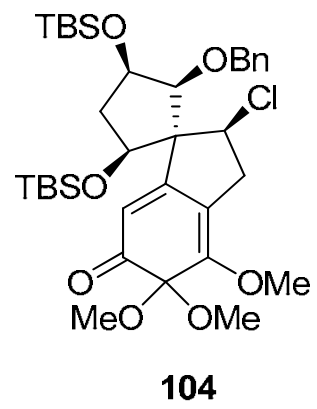

104

Scheme 7. Synthesis of $o$-benzoquinone 104

\subsection{Stereoselective Allylation}

Stereoselective 1,2-addition to the ketone of $\mathbf{1 0 4}$ was accomplished with a bisoxazoline ligated chiral allylzinc reagent by means of allylmagnesium chloride in 59\% yield (Scheme 8). This reagent was developed for stereoselective allylation of alkynyl ketones by Nakamura in $1998,{ }^{10}$ and it has proven highly selective in the synthesis of isohasbanan alkaloids in our lab, in which the substrates share the same cyclopentenone subunit as acutumine. We obtained a 79\% yield and 93:7 dr. 


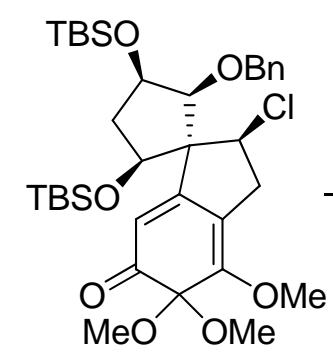

104

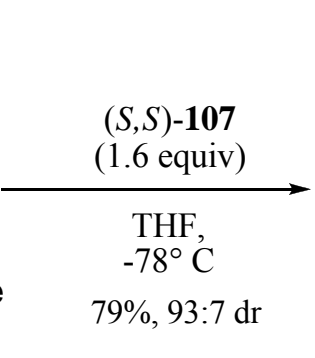

$\mathrm{R}=\mathrm{Ph}$

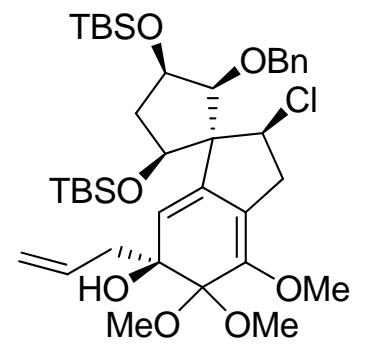

105

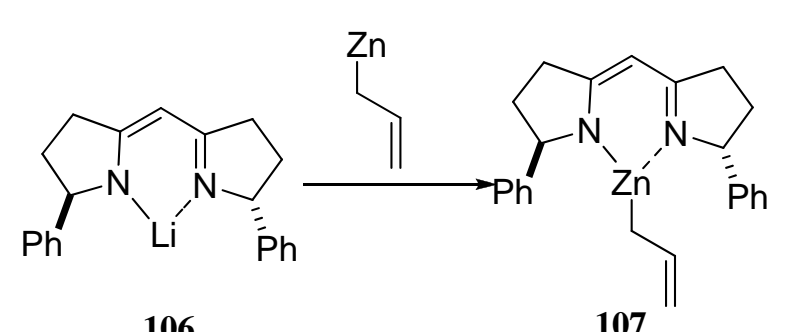

106

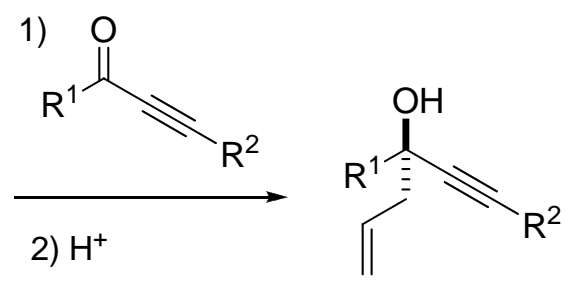

108

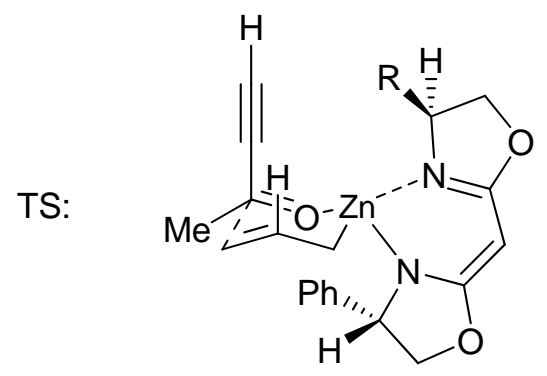

Scheme 8. Stereoselective allyl addition.

Although $^{9}$ a stoichiometric amount (1.6 equiv) of this reagent was required in this reaction, we were able to recover almost half of the chiral bisoxazoline ligand. The newly formed stereocenter was assigned according to the six-membered cyclic transition state for the asymmetric ketone allylation reported by Nakamura and co-workers(Figure 2). ${ }^{10}$ 


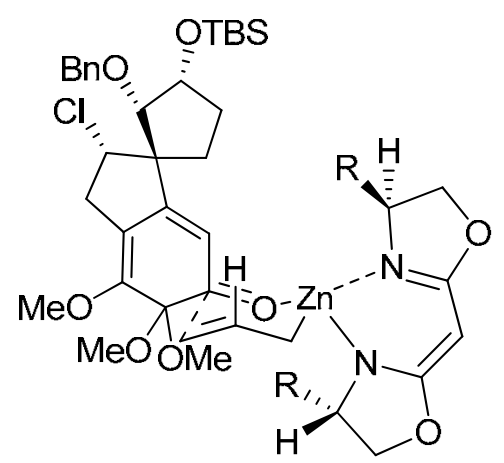

Figure 2. Proposed transition state for allylation of $\mathbf{1 0 4}$

\subsection{Exploration of Nakamura Reagent Allylation}

To explore the reagent-directed stereocontrol ability of the Nakamura reagent, we also tried allylmagnesium bromide and $(R, R)-\mathbf{1 1 0}$ allylation as control. As depicted in Table 2, allylmagnesium bromide only afforded a 70:30 mixture of $\mathbf{1 0 5}$ and its diastereomer 105' (entry 2), which confirmed that there is some substrate-directed stereocontrol in this reaction. When using $(R, R)-\mathbf{1 1 0}$, this substrate control was overcome by reagent control to provide product with 13:87 ratio. Though the Nakamura reagent has been seldom used in organic synthesis from its discovery, its exciting performance in acutumine and isohasubanan alkaloids synthesis demonstrated that it not limited to alkynyl ketones for which it was designed. 


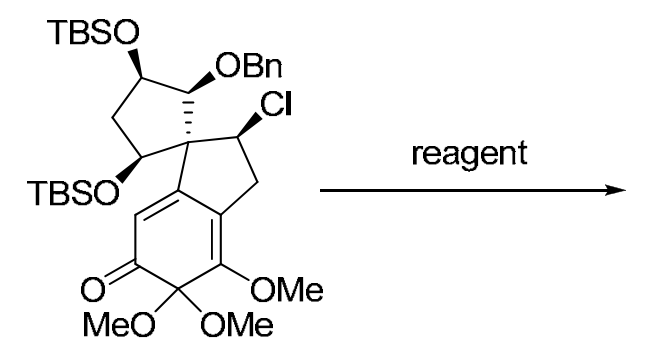

104

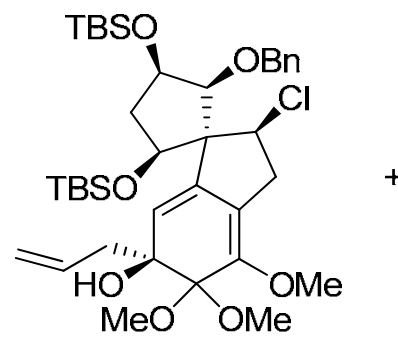

105

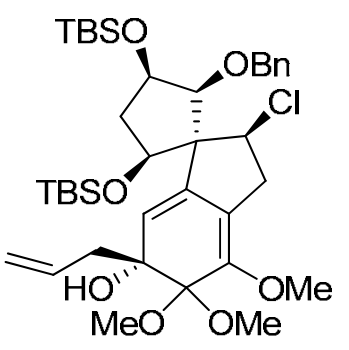

105'

\begin{tabular}{l|lcc} 
entry & reagent & yield & $\mathbf{1 0 5 : 1 0 5}$, \\
\hline $\mathbf{1}$ & $(S, S)-\mathbf{1 0 7}$ & 79 & $93: 7$ \\
$\mathbf{3}$ & allyMgBr & 88 & $70: 30$ \\
& $(R, R)-\mathbf{1 0 7}$ & 69 & $13: 87$
\end{tabular}

Table 2. Allylation of Ketone 104

\subsection{Anionic Oxy-Cope Rearrangement, Ozonolysis and Reductive Amination}

Exposure of 105 to potassium tert-butoxide and 18 -crown- 6 at $0{ }^{\circ} \mathrm{C}$ provided ketone 106 through anionic oxy-Cope rearrangement (Scheme 9). To cleave the double bond in the allyl group, different methods were evaluated including $\mathrm{OsO}_{4} / \mathrm{NaIO}_{4}$. All reactions were unsuccessful except ozonoysis. Unfortunately, at first we could not accurately control the amount of ozone in the reaction system. Our substrate is very sensitive to ozone due to the presence of an electron-rich methyl enol ether, so it would decompose after three seconds of bubbling ozone. So selective ozonolysis of the allyl group required us to find a way to accurately control the equivalents of ozone. Wender and co-workers recently proposed an idea to control the ozone amount by dissolving 
ozone in methylene chloride. ${ }^{11}$ We used a similar approach by dissolving ozone in ethyl acetate and measuring the concentration by titration, which helped control the equivalents of ozone in the reaction system. The concentration of a saturated solution of $\mathrm{O}_{3}$ in EtOAc is $0.007 \mathrm{M}$ as determined by titrating with styrene. Treatment of $\mathbf{1 0 6}$ with 1.5 equiv of $\mathrm{O}_{3}$ in EtOAc provided 30\% aldehyde product and 30\% recovered staring material. The yield could be optimized by moderating the reactivity of ozone by using pyridine as additive. The Donohoe group reported a similar approach in their recent synthesis of deoxypukalide. ${ }^{12}$ The best yields (54\% of amine, $27 \%$ recovered starting material) were obtained by adding 1.5 equiv of $\mathrm{O}_{3} /$ EtOAC solution to a solution of $\mathbf{1 0 6}$, pyridine, and EtOAc mixture, the reductive amination was conducted in the same pot.

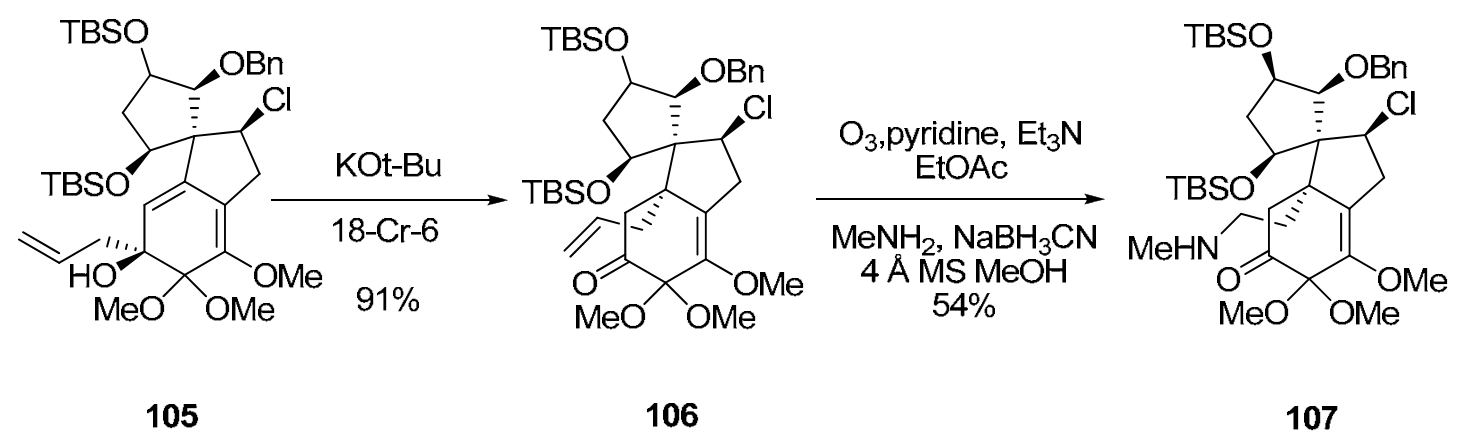

Scheme 9. Anionic oxy-Cope rearrangement,ozonolysis and reductive amination 


\subsection{Development of Cyclization Conditions in Model System}

To develop optimized cyclization from 108 to 109, different conditions were tried on model system 108 (Scheme 10). Though we used TMSOTf to promote Michael addition in model syntheses before, ${ }^{13}$ it provided low yields on this more complex molecule. After screening different Lewis and Brønsted acids including acid acetic acid, $\mathrm{HCl}$, HFIP ${ }^{14}$ and TFA, we found $\mathrm{BCl}_{3}$ was the best catalyst to provide pyrrolidine $\mathbf{1 0 9}$ (Table 3). It is surprising that $\mathrm{HCl}$ (entry 3 ) afford undesired hemiaminal $\mathbf{1 1 0}$ as isohasubanan alkaloids. It is still under investigation why $\mathbf{1 0 9}$ was the only product under these conditions. HFIP can provide modest yields of enol 109 without adding any Lewis and Brønsted acids. But the yield was not improved by using HFIP as the only solvent with $\mathrm{BCl}_{3}$.

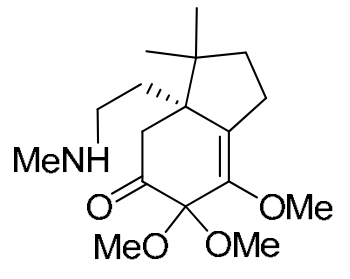

108

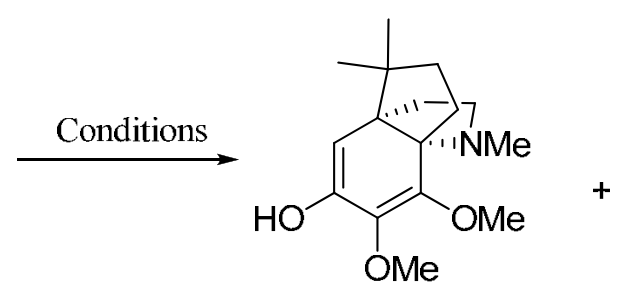

109

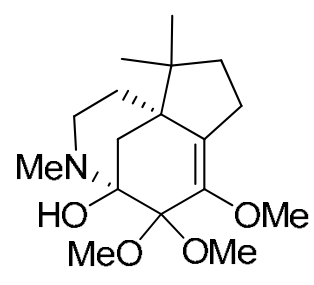

110

Scheme 10. Michael type cyclization on model structure 


\begin{tabular}{|c|c|c|}
\hline entry & conditions $^{a}$ & product $^{b}$ \\
\hline 1 & TFA (5 equiv), $\mathrm{CH}_{2} \mathrm{Cl}_{2}$ & 109(31) \\
\hline 2 & TFA ( 5 equiv), $\mathrm{CH}_{2} \mathrm{Cl}_{2}, 0^{\circ} \mathrm{C}$ & $109(41)$ \\
\hline 3 & $\mathrm{HCl}$ (2 equiv), $\mathrm{MeOH}$ & $110(10)$ \\
\hline 4 & HOAc ( 3 equiv), $\mathrm{MeOH}$ & $109(12)$ \\
\hline 5 & $\mathrm{BCl}_{3}$ ( 1 equiv), $\mathrm{MeOH}$ & $\mathbf{1 0 9}(19)^{C}$ \\
\hline 6 & $\mathrm{BCl}_{3}$ (2 equiv), $\mathrm{MeOH}$ & $109(27)$ \\
\hline 7 & $\mathrm{BCl}_{3}$ ( 3 equiv), $\mathrm{MeOH}$ & 109(39) \\
\hline 8 & $\mathrm{BCl}_{3}$ (4 equiv), $\mathrm{MeOH}$ & $109(38)$ \\
\hline 9 & $\mathrm{BCl}_{3}$ (3 equiv), $\mathrm{CH}_{2} \mathrm{Cl}_{2}, 0^{\circ} \mathrm{C}$ & $109(35)$ \\
\hline 10 & $\mathrm{BCl}_{3}$ (3 equiv), $\mathrm{CH}_{2} \mathrm{Cl}_{2},-15^{\circ} \mathrm{C}$ & 109(39) \\
\hline 11 & $\mathrm{BCl}_{3}$ (3 equiv), $\mathrm{CH}_{2} \mathrm{Cl}_{2},-40^{\circ} \mathrm{C}$ & $109(41)$ \\
\hline 12 & $\mathrm{BCl}_{3}$ (3 equiv), $\mathrm{CH}_{2} \mathrm{Cl}_{2},-78^{\circ} \mathrm{C}$ & $109(37)$ \\
\hline 13 & HFIP, ${ }^{d} 0^{\circ} \mathrm{C}$ & $109(27)$ \\
\hline 14 & HFIP, $-40^{\circ} \mathrm{C}$ & $109(31)$ \\
\hline 15 & $\mathrm{BCl}_{3}$ ( 3 equiv), $\mathrm{HFIP},-40^{\circ} \mathrm{C}$ & $109(40)$ \\
\hline \multicolumn{3}{|c|}{${ }^{a}$ Reactions were conducted at room temperature in the presence of $4 \AA$ MS unless otherwise indicated. ${ }^{b}$} \\
\hline
\end{tabular}

Table 3. Development of cyclization conditions in model system 


\subsection{1 $\mathrm{BCl}_{3}$ Catalyzed Michael-Type Cyclization}

We obtained $45 \%$ yield when the optimized $\mathrm{BCl}_{3}$ promoted cyzlization was applied to amine 107 (Scheme 11). It is noteworthy to mention that we did not observe any undesired cyclization byproduct as in our isohasubanan alkoloid synthesis. This exciting outcome might be attributed to the different electron density and different substituents in the spirocycle. Most importantly, we did not observe the hemiaminal isomer of $\mathbf{1 0 7}$ in the acutumine synthesis. Cyclization of the aminoketone to form a hemiaminal would have prevented the desired cyclization and would have formed undesired hasubanon alkaloids. ${ }^{15}$

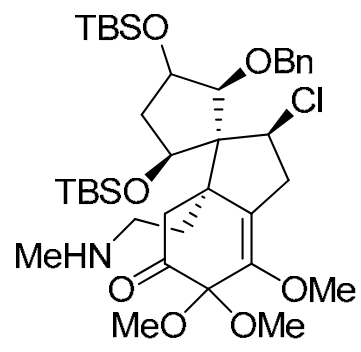

107

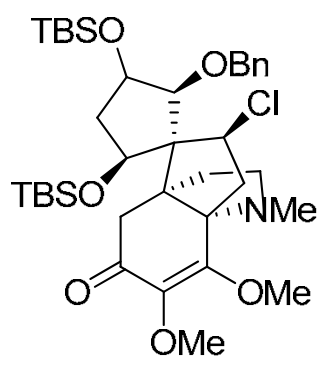

111

Scheme 11. Michael-type cyclization

\subsection{Total Synthesis of (-)-Acutumine}

Both TBS protecting groups of $\mathbf{1 1 1}$ were removed and the resulting diol was oxidized by TPAP-NMO to diketone 112 (Scheme 11). The diol product is very unstable even when stored in the freezer. So the subsequent oxidation was performed as soon as possible after cleavage of the TBS protection. The following steps in the synthesis consist 
of deprotection and methylation. Two different orders for these reactions were tested. Deprotection and then methylation proved slightly better than methylation followed by deprotection. Also, in the last step, $\mathrm{CH}_{2} \mathrm{~N}_{2}$ proved to be a better methylation reagent then $\mathrm{TMSCHN}_{2}$. The drawback is that undesired regioisomer $\mathbf{1 1 4}$ was also obtained. We obtained a 1.3:1 mixture of products favoring acutumine. Fortunately, treatment of $\mathbf{1 1 3}$ with the Lewis acid $\mathrm{TiCl}_{4}$ in the presence of $\mathrm{Et}_{3} \mathrm{~N}$ produced $\mathbf{1}$ as the major product with 3.7:1 ratio in favor of $\mathbf{1}$ (Scheme 12). ${ }^{16}$

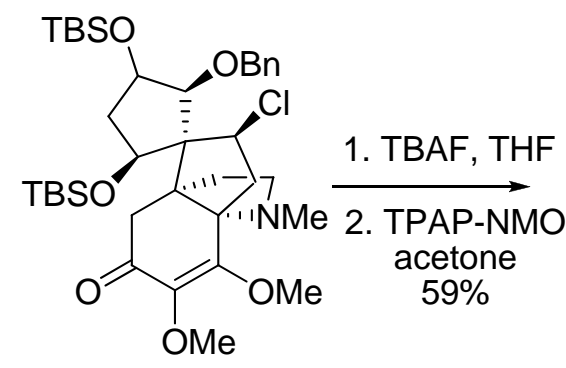

111

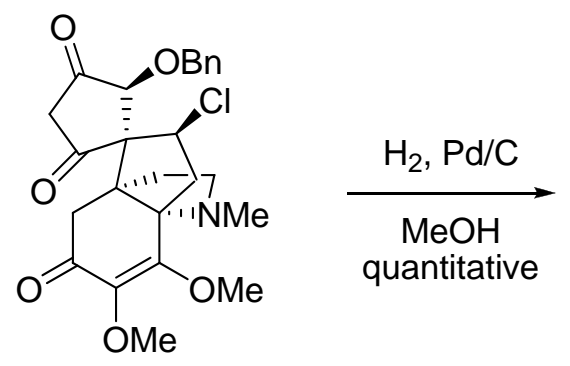

112

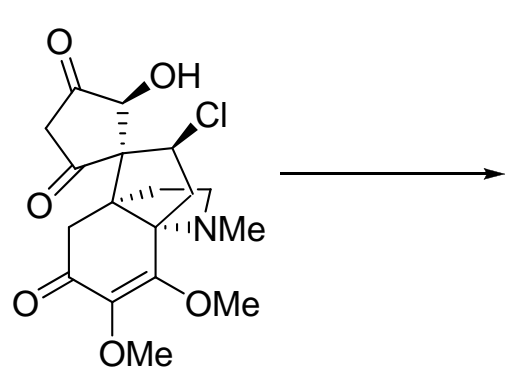

113

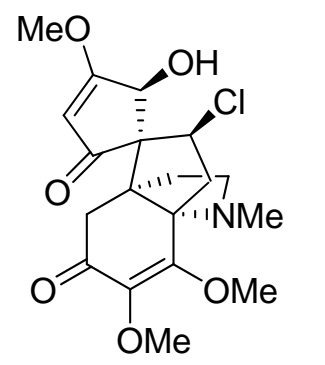

1

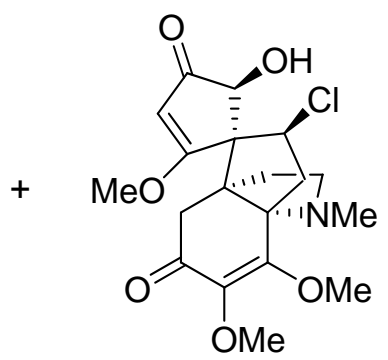

114

$35 \%$

$14 \%$

$\mathrm{TiCl}_{4}, \mathrm{Et}_{3} \mathrm{~N}, \mathrm{MeOH} \quad 52 \%$

Scheme 12. Synthesis of acutumine

Synthetic acutumine was identical to the authentic sample by TLC, MS, ${ }^{1} \mathrm{H}$ NMR, and ${ }^{13} \mathrm{C}$ NMR. The rotation of synthetic acutumine is $[\alpha]^{25}-171$ (c 0.81 , pyridine), 
while natural acutumine was reported to be $[\alpha]^{25}{ }_{\mathrm{D}}-206$ (c 0.69 , pyridine). The ${ }^{1} \mathrm{H}$ and ${ }^{13} \mathrm{C}$ NMR spectroscopy comparison is shown below (Figure 3, 4). 

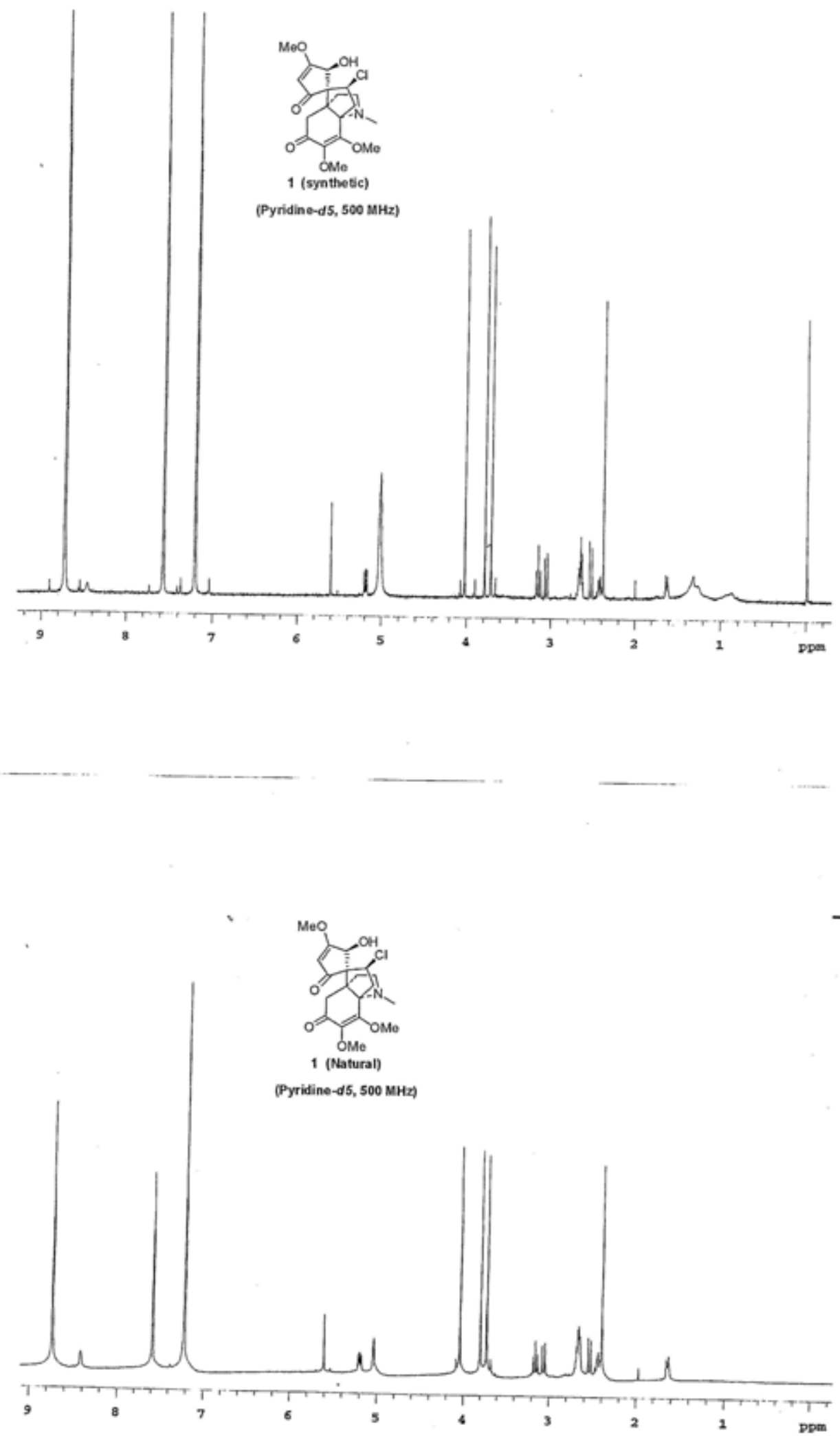

Figure 3. Comparison of ${ }^{1} \mathrm{H}$ NMR spectroscopy between synthetic and natural acutumine 

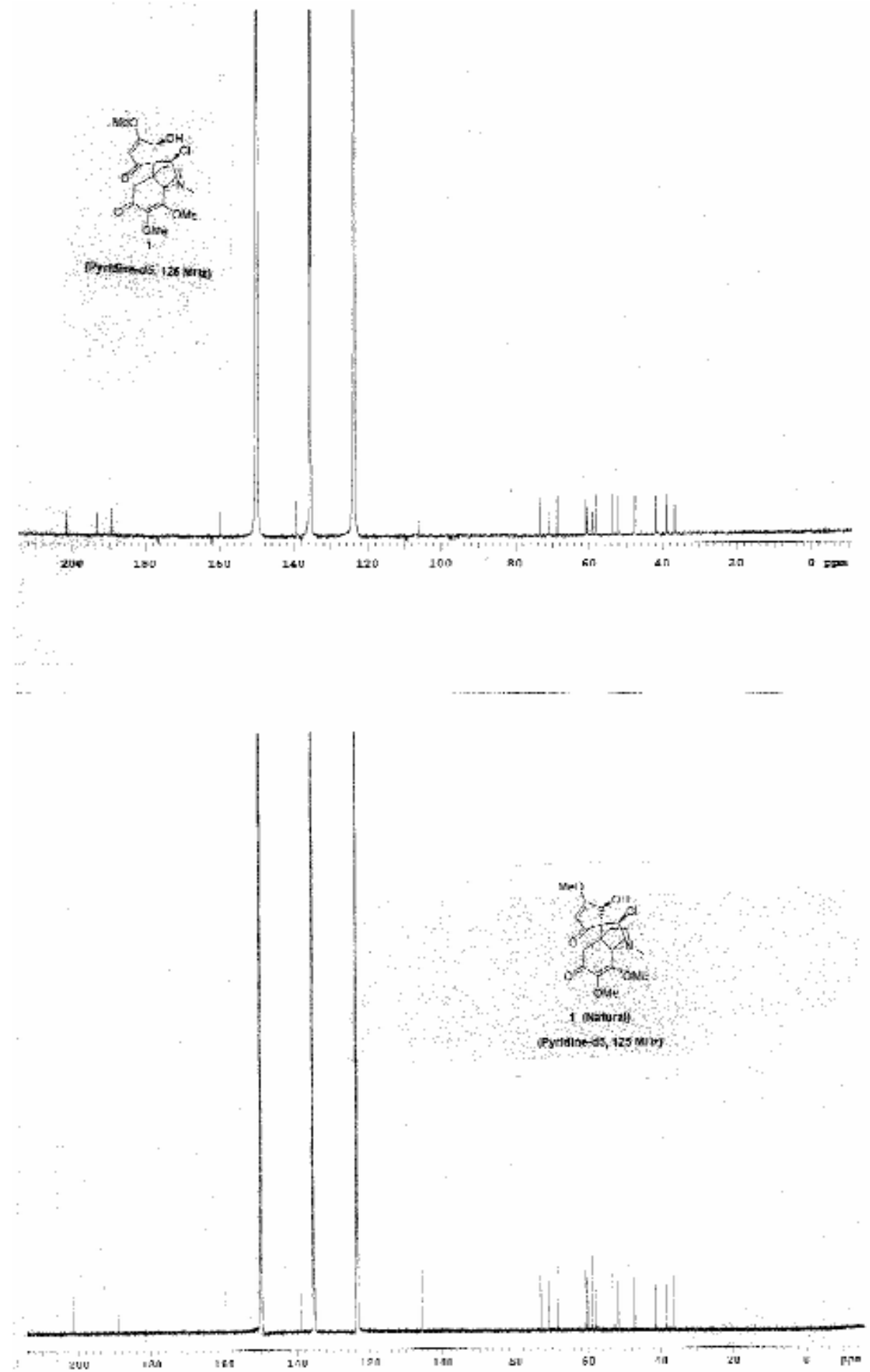

Figure 3. Comparison of ${ }^{13} \mathrm{C}$ NMR spectroscopy between synthetic and natural acutumine 


\subsection{Reference}

1. Murphy, J. A. In Radicals in Organic Synthesis. Wiley-VCH: 2001; p 298.

2. Albert, M.; Fensterbank, L.; Lacote, E.; Malacria, M. Top. Curr. Chem. 2006, 264, 22647.

3. Lampard, C.; Murphy, J. A.; Lewis, N. J. Chem. Soc. Chem. Commun. 1993, 3, 295.

4. Nozaki, K.; Oshima, K.; Utimoto, K. Tetrahedron Lett. 1988, 29, 1041.

5. Nozaki, K.; Oshima, K.; Utimoto, K. Bull. Chem. Soc. Jpn. 1991, 64, 403.

6. Deardorff, D. R.; Linde, R. G.; Martin, A. M.; Shulman, M. J. J. Org. Chem. 1989, $54,2759$.

7. Deardorff, D. R.; Windham, C. Q.; Craney, C. L. Org. Syn. 1996, 73, 25.

8. $\quad$ Corey, E. J.; Kim, C. U.; Takeda, M. Tetrahedron Lett. 1972, 42, 4339.

9. Artman, G. D.; Grubbs, A. W.; Williams, R. M. J. Am. Chem. Soc. 2007, 129, 6336.

10. Nakamura, M.; Hirai, A.; Sogi, M.; Nakamura, E. J. Am. Chem. Soc. 1998, 120, 5846.

11. Wender, P. A.; DeChristopher, B. A.; Schrier, A. J. J. Am. Chem. Soc. 2008, $130,6658$.

12. Donohoe, T. J.; Ironmonger, A.; Kershaw, N. M. Angew. Chem. Int. Ed. 2008, 47, 7314.

13. Reeder, M. D.; Srikanth, G. S.; Jones, S. B.; Castle, S. L. Org Lett. 2005, 7, 1089.

14. Ratnikov, M. O.; tumanov, V. V.; Smit, W. A. Angew. Chem. Int. Ed. 2008, 47, 9739. 
15. Nielsen, D. K.; Nielsen, L. L.; Jones, S. B.; Toll, L.; Asplund, M. C.; Castle, S. L. J. Org. Chem. 2009, 74, 1187.

16. Clerici, A.; Pastori, N.; Porta, O. Tetrahedron 2001, 57, 217. 


\section{Chapter 5. Conclusion and Future Work}

\subsection{Conclusion and Future Work}

In conclusion, we have finished the total synthesis of enantiopure natural product acutumine, which is the first total synthesis of this challenging alkaloid.

During the exploration, we discovered a novel radical-polar crossover reaction consisting of an intramolecular aryl radical conjugate addition and hydroxylation of an enolate. One spirocycle and two stereocenters were created in this step, and an alcohol was installed. We believe this tandem reaction will be very useful in organic synthesis. So it is worthy to do more investigation on this methodology in the future by testing different substrates to explore the scope and limitations of this reaction (Scheme 1).<smiles>[X]c1ccc(C([R])C2=CC(=O)CC2)c([18OH])c1</smiles>

118 radical-polar crossover<smiles>C1CCCC1</smiles>
$\mathrm{R}=\mathrm{Cl}, \mathrm{OMe}, \mathrm{H}$ $\mathrm{X}=\mathrm{OMe}, \mathrm{H}, \mathrm{F}$ $\mathrm{m}=1,2$ $\mathrm{n}=1-3$<smiles>O=C1C=IC2CCCCC2=C1</smiles>

120

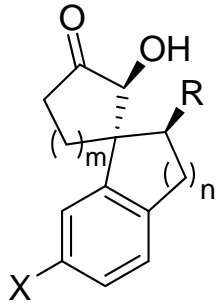

119<smiles>O=C1CCCC2(CCC=[In]2)[C@H]1O</smiles>

121

Scheme 1. Radical-polar crossover reactions on different substrate 
Also, replacing the hydroxylation step with an electrophilic amination would lead to $\alpha$-amino ketone derivatives (Scheme 2$).{ }^{1-3}$

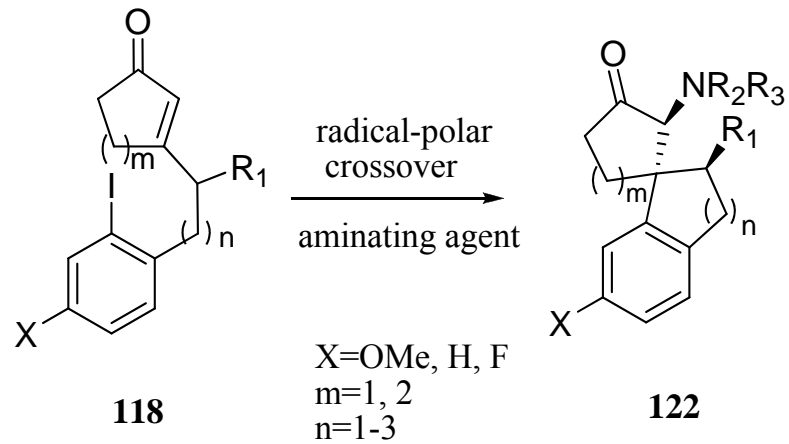

Scheme 2. Tandem cyclization-amination

The Nakamura reagent was not used after its discovery because it was thought to be limited to alkynyl ketones. Also, it has never been used in natural product total syntheses before our group's isohasubanan alkaloids synthesis. ${ }^{4}$ So it is a breakthrough to find it also works on complicated cyclic ketone substrates. It could be very useful in reagent-controlled stereoselective allylation of different ketones. Our group has started the research to explore the scope and limitations of Nakamura reagent. Other noteworthy reactions include a pyridine adjusted selective ozonolysis, an anionic oxy-Cope rearrangement to build a congested quaternary carbon and a Lewis acid promoted Michael-type cyclization. 


\subsection{Reference}

1. Katritzky, A. R.; Le, K. N. B.; Khelashvili, L.; Mohapatra, P. P. J. Org. Chem. 2006, 71, 9861 .

2. Ooi, T.; Takeuchi, M.; Kato, D.; Uematsu, Y.; Tayama, E.; Sakai, D.; Maruoka, K. J. Am. Chem. Soc. 2005, 127, 5073.

3. Garcia Ruano, J. L.; Lopez-Cantarero, J.; de Haro, T.; Aleman, J. C., M. B. Tetrahedron 2006, 62, 12197.

4. Nielsen, D. K.; Nielsen, L. L.; Jones, S. B.; Toll, L.; Asplund, M. C.; Castle, S. L. J. Org. Chem. 2009, 74, 1187. 


\section{Chapter 6 Experimental Section}

Benzene, dimethylformamide, methanol, methylene chloride, tetrahydrofuran, and toluene were dried by passage through a solvent drying system containing cylinders of activated alumina. Flash chromatography was carried out using 60-230 mesh silica gel. ${ }^{1} \mathrm{H}$ NMR spectra were acquired on 300 or $500 \mathrm{MHz}$ spectrometers with chloroform (7.27 $\mathrm{ppm})$ or pyridine $(8.74 \mathrm{ppm})$ as internal references. Signals are reported as follows: $\mathrm{s}$ (singlet), d (doublet), $\mathrm{t}$ (triplet), q (quartet), dd (doublet of doublets), dt (doublet of triplets), br s (broad singlet), m (multiplet). Coupling constants are reported in hertz (Hz). ${ }^{13} \mathrm{C}$ NMR spectra were acquired on spectrometers operating at 75 or $125 \mathrm{MHz}$ with chloroform $(77.23 \mathrm{ppm})$ or pyridine (149.80) as internal references. Infrared spectra were obtained on an FT-IR spectrometer. Mass spectral data were obtained using ESI techniques.<smiles>COc1ccc(C=O)c(O)c1OC</smiles>

59

2-hydroxy-3,4-dimethoxybenzaldehyde (59). A solution of 57 (764 mg, 3.9 mmol) in anhydrous DMF ( $15 \mathrm{ml})$ was treated with sodium 2-methylpropane-2-thiolate $(t-B u N a S, 0.437 \mathrm{~g}, 3.9 \mathrm{mmol})$ at $100^{\circ} \mathrm{C}$ and stirred for $30 \mathrm{~min}$. The resultant mixture was 
slowly cooled to room temperature and stirred for 1 hour. It was then diluted with $\mathrm{CHCl}_{3}$ (15 ml) and washed with Sat aq $\mathrm{NH}_{4} \mathrm{Cl}(15 \mathrm{ml})$. The combined aqueous layers were backextracted with $\mathrm{CHCl}_{3}(3 \times 10 \mathrm{ml})$, and the combined organic layers were dried $\left(\mathrm{MgSO}_{4}\right)$ and concentrated in vacuo. Flash chromatography $\left(\mathrm{SiO}_{2}, 2.5 \times 10 \mathrm{~cm} .10 \%\right.$ EtOAchexane elution) afforded 59 (511 mg, $2.8 \mathrm{mmol}, 71.8 \%)$ as yellow oil: ${ }^{1} \mathrm{H}$ NMR (300 $\left.\mathrm{MHz}, \mathrm{CHCl}_{3}\right) \delta 11.21(\mathrm{~s}, 1 \mathrm{H}), 7.57(\mathrm{~d}, J=9 \mathrm{~Hz}, 1 \mathrm{H}), 7.54(\mathrm{~s}, 1 \mathrm{H}), 6.82(\mathrm{~d}, J=9 \mathrm{~Hz}, 1 \mathrm{H})$, $4.01(\mathrm{~s}, 3 \mathrm{H}), 3.94(\mathrm{~s}, 3 \mathrm{H}) ;{ }^{13} \mathrm{C}\left(300 \mathrm{MHz}, \mathrm{CDCl}_{3}\right) \delta 191.5,157.5,151.2,140.3,124.5$, 121.2, 107.6, 56.4, 55.2; IR (film) $v_{\max } 2054,1766,877,556 \mathrm{~cm}^{-1}$; HRMS (ESI) $\mathrm{m} / \mathrm{z}$ 182.0573 $\left(\mathrm{M}^{+}, \mathrm{C}_{9} \mathrm{H}_{10} \mathrm{O}_{4}\right.$ requires 182.0579).

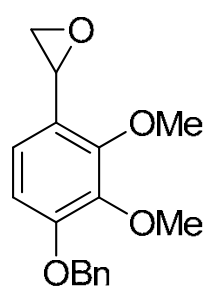

62

2-(4-(benzyloxy)-2, 3-dimethoxyphenyl)oxirane (62). Solid NaH (0.125 g, 3.12 mmol) was washed with 1-2ml hexane in an over-dried round bottom flask, then removeed hexane with syringe. $2.46 \mathrm{ml}$ DMSO was added and stirred at $70^{\circ} \mathrm{C}$ for $45 \mathrm{~min}$ under nitrogen (use flushing nitrogen, an evolution of gas will create excess pressure). The resultant mixture was slowly cooled to room temperature and stirred for $40 \mathrm{~min}$ under nitrogen. $2.5 \mathrm{ml}$ THF was added and the mixture was cool to $0-5^{\circ} \mathrm{C}$ in ice bath. Solid $\left(\mathrm{CH}_{3}\right)_{3} \mathrm{SI}(0.64 \mathrm{~g}, 3.12 \mathrm{mmol})$ was added over $10 \mathrm{~min}$ under $0-5^{\circ} \mathrm{C}$. A solution of 61 ( $0.2 \mathrm{~g}, 0.75 \mathrm{mmol})$ in $1 \mathrm{ml}$ THF was added and stirred for $25 \mathrm{~min}$. Then the mixture was 
warmed back to room temperature and stirred for 12 hour, diluted with water $(3 \mathrm{ml})$, extracted with EtOAC $(3 \times 3 \mathrm{ml})$. The combined organic layers were dried $\left(\mathrm{MgSO}_{4}\right)$, and concentrated in vacuo. Flash chromatography $\left(\mathrm{SiO}_{2}, 2.5 \times 18 \mathrm{~cm}\right.$. 10\% EtOAc-hexane elution) afforded $62(0.19 \mathrm{~g}, 0.66 \mathrm{mmol}, 88 \%)$ as colorless oil: ${ }^{1} \mathrm{H}$ NMR $\left(300 \mathrm{MHz}, \mathrm{CHCl}_{3}\right) \delta$ 7.56-7.44 (m, 5H), $6.63(\mathrm{~d}, 1 \mathrm{H}, J=9 \mathrm{~Hz}), 6.44(\mathrm{~d}, 1 \mathrm{H}, J=9 \mathrm{~Hz})$, $5.34(\mathrm{~s}, 2 \mathrm{H}), 3.90(\mathrm{~m}, 1 \mathrm{H}), 3.83(\mathrm{~s}, 3 \mathrm{H}), 3.81(\mathrm{~s}, 3 \mathrm{H}), 2.84(\mathrm{~m}, 2 \mathrm{H}) ;{ }^{13} \mathrm{C}\left(75 \mathrm{MHz}, \mathrm{CDCl}_{3}\right)$ $\delta 152.3,148.4,142.5,140.1,129.7,124.3,124.1,119.5,117.7,106.3,70.1,61.4,53.2$, 51.7; IR (film) $v_{\max } 2088,1542,922,855,787 \mathrm{~cm}^{-1}$; HRMS (ESI) $\mathrm{m} / \mathrm{z} 286.1233\left(\mathrm{M}^{+}\right.$, $\mathrm{C}_{17} \mathrm{H}_{18} \mathrm{O}_{4}$ requires 286.1205).<smiles>COc1ccc(CC=O)c(OC)c1OC</smiles>

63

2-(4-(benzyloxy)-2,3-dimethoxyphenyl)acetaldehyde (63). A solution of (methoxymethyl)triphenylphosphonium chloride $(0.61 \mathrm{~g}, 1.77 \mathrm{mmol})$ in anhydrous THF $(2.0 \mathrm{~mL})$ at $0{ }^{\circ} \mathrm{C}$ was treated dropwise with a solution of KOt-Bu $(210 \mathrm{mg}, 1.77 \mathrm{mmol})$ in anhydrous THF $(0.7 \mathrm{~mL})$. The resultant mixture was warmed to rt and stirred under $\mathrm{N}_{2}$ for $30 \mathrm{~min}$, then treated with a solution of $\mathbf{6 1}(223 \mathrm{mg}, 0.84 \mathrm{mmol})$ in anhydrous THF $(1.5 \mathrm{~mL})$ and stirred at $\mathrm{rt}$ under $\mathrm{N}_{2}$ for $16 \mathrm{~h}$. The reaction was quenched by the addition of brine $(4 \mathrm{~mL})$, extracted with EtOAc $(3 \times 4 \mathrm{~mL})$, and concentrated in vacuo. The crude enol ether was dissolved in acetone $(4.0 \mathrm{~mL})$, then treated with concentrated $\mathrm{HCl}(1.0 \mathrm{~mL})$ 
and $\mathrm{H}_{2} \mathrm{O}(1.0 \mathrm{~mL})$. The resultant mixture was refluxed for $12 \mathrm{~h}$, extracted with $\mathrm{Et} 2 \mathrm{O}(3 \times$ $5 \mathrm{~mL}$ ), dried (MgSO4), and concentrated in vacuo. Flash chromatography $\left(\mathrm{SiO}_{2}, 1.5 \times 12\right.$ cm, 10\% EtOAc-hexanes elution) afforded 63 (192 mg, $0.67 \mathrm{mmol}, 80 \%)$ as a colorless oil: ${ }^{1} \mathrm{H} \mathrm{NMR}\left(\mathrm{CDCl}_{3}, 500 \mathrm{MHz}\right) \delta 9.82(\mathrm{~s}, 1 \mathrm{H}) 7.45-7.22(\mathrm{~m}, 5 \mathrm{H}), 6.82(\mathrm{~d}, 1 \mathrm{H}, J=9 \mathrm{~Hz})$, $6.59(\mathrm{~d}, 1 \mathrm{H}, J=9 \mathrm{~Hz}), 5.15(\mathrm{~s}, 2 \mathrm{H}), 3.91(\mathrm{~s}, 1 \mathrm{H}), 3.89(\mathrm{~s}, 1 \mathrm{H}), 3.57(\mathrm{~s}, 2 \mathrm{H}) ;{ }^{13} \mathrm{C} \mathrm{NMR}$ (CDCl3, $75 \mathrm{MHz}) \delta 174.2,155.2,153.3,143.6,137.1,127.4,126.1,126.0,125.8,122.4$, 109.2, 78.3, 78.1, 75.9, 72.6, 62.5, 61.8, 37.2, 35.6; IR (film) $v_{\max } 2832,1734,1523$, 1410, 961, 758,621 cm ${ }^{-1}$; HRMS (ESI) m/z $286.1198\left(\mathrm{M}^{+}, \mathrm{C}_{17} \mathrm{H}_{18} \mathrm{O}_{4}\right.$ requires 286.1201).<smiles>COc1ccc(CC(=O)O)c(OC)c1OC</smiles>

65

2-(4-(benzyloxy)-2,3-dimethoxyphenyl)acetic acid (63). A solution of 63 in 5 $\mathrm{ml}$ acetone at $0^{\circ} \mathrm{C}$ and treated with Jones reagent $(0.2 \mathrm{ml})$. The resultant mixure was stirred overnight $(16 \mathrm{~h})$ at $0^{\circ} \mathrm{C}$. The reaction was quenched by the addition of sat aq sodium bisulfide till till the brown color has disappeared from the upper layer, extracted with EtOAc $(3 \times 15 \mathrm{~mL})$, dried $(\mathrm{MgSO} 4)$, and concentrated in vacuo. Flash chromatography $\left(\mathrm{SiO}_{2}, 1.5 \times 12 \mathrm{~cm}, 10 \%\right.$ EtOAc-hexanes elution) afforded 65 (192 mg, $0.67 \mathrm{mmol}, 80 \%)$ as white solid crystal: ${ }^{1} \mathrm{H} \mathrm{NMR}\left(\mathrm{CDCl}_{3}, 500 \mathrm{MHz}\right) \delta 7.47-7.26(\mathrm{~m}, 5 \mathrm{H})$, $6.87(\mathrm{~d}, 1 \mathrm{H}, J=9 \mathrm{~Hz}), 6.71(\mathrm{~d}, 1 \mathrm{H}, J=9 \mathrm{~Hz}), 5.17(\mathrm{~s}, 2 \mathrm{H}), 3.94(\mathrm{~s}, 1 \mathrm{H}), 3.92(\mathrm{~s}, 1 \mathrm{H}), 3.62$ $(\mathrm{s}, 2 \mathrm{H}) ;{ }^{13} \mathrm{C}\left(300 \mathrm{MHz} ; \mathrm{CDCl}_{3}\right) \delta 177.8,152.8,152.3,142.9,137.2,128.8,128.2,127.5$, 125.1, 120.6, 109.4, 77.7, 77.3, 76.9, 71.2, 61.1, 61.0, 35.6, 31.2; IR (film) $v_{\max } 2915$, 
2822, 1779, 1647, $1510,1022,773 \mathrm{~cm}^{-1}$; HRMS (ESI) $\mathrm{m} / \mathrm{z} 303.1222\left(\mathrm{MH}^{+}, \mathrm{C}_{17} \mathrm{H}_{18} \mathrm{O}_{5}\right.$ requires 303.1232).<smiles>COCN(C)C(=O)COc1c(OC)cccc1OC</smiles>

43

2-(4-(benzyloxy)-2,3-dimethoxyphenyl)-N-methoxy-N-methylacetamide (43). A solution of acid $65(0.064 \mathrm{~g}, 0.21 \mathrm{mmol})$ in $3 \mathrm{ml} \mathrm{CH}_{2} \mathrm{Cl}_{2}$ was treated with $\mathrm{Et}_{3} \mathrm{~N}(0.032$ $\mathrm{ml}, 0.23 \mathrm{mmol}$ ) and stirred for $15 \mathrm{~min}$. The resultant mixture was treated with PivCl $(0.025 \mathrm{ml}, 0.21 \mathrm{mmol}), \mathrm{MeO}\left(\mathrm{CH}_{3}\right) \mathrm{NH} \cdot \mathrm{HCl}(0.02 \mathrm{~g}, 0.01 \mathrm{mmol})$ and $\mathrm{Et}_{3} \mathrm{~N}$ $(0.058 \mathrm{ml}, 0.42 \mathrm{mmol})$ dropwisely. After stirring for 2 more hours, the reaction was quenched with water, extracted with $\mathrm{CH}_{2} \mathrm{Cl}_{2}(3 \times 3 \mathrm{ml})$, dried over $\mathrm{MgSO}_{4}$ and concentrated in vacuo. Flash chromatography $\left(\mathrm{SiO}_{2}, 1.5 \times 8 \mathrm{~cm}, 10 \%\right.$ EtOAc-hexanes elution) afforded 43 (0.056 g, $0.16 \mathrm{mmol}, 78 \%)$ as pale yellow solid: ${ }^{1} \mathrm{H}$ NMR $\left(300 \mathrm{MHz}, \mathrm{CHCl}_{3}\right) \delta 7.48-7.37(\mathrm{~m}, 5 \mathrm{H}), 6.88(\mathrm{~d}, 1 \mathrm{H}, J=9 \mathrm{~Hz}), 6.70(\mathrm{~d}, 1 \mathrm{H}, J=9 \mathrm{~Hz}), 5.12$ (s, 2H), 3.92 (s, 3H), $3.74(\mathrm{~s}, 3 \mathrm{H}), 3.71(\mathrm{~s}, 3 \mathrm{H}), 3.70(\mathrm{~s}, 3 \mathrm{H}), 3.24(\mathrm{~s}, 2 \mathrm{H}) ;{ }^{13} \mathrm{C}(75 \mathrm{MHz}$, $\left.\mathrm{CDCl}_{3}\right) \delta 152.3,143.0,137.4,128.8,128.1,127.5,125.1,122.1,109.6,71.2,61.4,61.1$, 61.0, 60.6, 33.4, 32.7, 29.9, 14.4; IR (film) $v_{\max } 2829,2514,1739,1566,1087,922,773$ $\mathrm{cm}^{-1}$; HRMS (ESI) m/z $346.1642\left(\mathrm{MH}^{+}, \mathrm{C}_{19} \mathrm{H}_{24} \mathrm{NO}_{5}\right.$, requires 346.1654). 
<smiles>COc1c(CC(=O)C2=C[C@@H]([OH+])C[C@H]2O[SbH3])ccc(OCc2ccccc2)c1OC</smiles>

42

\section{2-(4-(benzyloxy)-2,3-dimethoxyphenyl)-1-((3R,5S)-3,5-bis(tert-}

butyldimethylsilyloxy)cyclopent-1-enyl)ethanone (42). A portion of the $t$-BuLi (1.6 M solution in THF, $36 \mu \mathrm{L}, 0.058 \mathrm{mmol})$ was added to a solution of $44(26.4 \mathrm{mg}, 0.058$ mmol) in anhydrous $\mathrm{THF}(200 \mu \mathrm{L})$ at $-78{ }^{\circ} \mathrm{C}$, and the mixture was stirred at $-78^{\circ} \mathrm{C}$ for $10 \mathrm{~min}$ and treated with a precooled $\left(-78^{\circ} \mathrm{C}\right)$ solution of $43(18.3 \mathrm{mg}, 0.053 \mathrm{mmol})$ in anhydrous THF $(200 \mu \mathrm{L})$. The resultant mixture was stirred at $-78{ }^{\circ} \mathrm{C}$ for $1 \mathrm{~h}$, then treated with sat aq $\mathrm{NH}_{4} \mathrm{Cl}(1 \mathrm{~mL})$ and extracted with EtOAc $(3 \times 2 \mathrm{~mL})$. The combined organic layers were dried $\left(\mathrm{MgSO}_{4}\right)$ and concentrated in vacuo. Flash chromatography $\left(\mathrm{SiO}_{2}, 1.5 \times 8 \mathrm{~cm}, 10 \%\right.$ EtOAc-hexanes elution) afforded 42 (22.4 mg, $\left.0.036 \mathrm{mmol}, 59 \%\right)$ as a pale yellow oil: $[\alpha]^{25}+16.7\left(c 1.01, \mathrm{CH}_{2} \mathrm{Cl}_{2}\right) ;{ }^{1} \mathrm{H} \mathrm{NMR}\left(\mathrm{CDCl}_{3}, 300 \mathrm{MHz}\right) \delta 7.52-$ $7.37(\mathrm{~m}, 5 \mathrm{H}), 7.45(\mathrm{~d}, 1 \mathrm{H}, J=8.5 \mathrm{~Hz}), 7.25(\mathrm{~d}, 1 \mathrm{H}, J=8.5 \mathrm{~Hz}), 5.18(\mathrm{~s}, 2 \mathrm{H}), 4.88-4.85$ (m, 1H), 4.62-4.59 (m, 1H), $4.05(\mathrm{~s}, 2 \mathrm{H}), 3.91(\mathrm{~s}, 3 \mathrm{H}), 3.88(\mathrm{~s}, 3 \mathrm{H}), 2.75(\mathrm{dt}, \mathrm{J}=12.5,8$ Hz, 1H), 1.69 (dt, J = 12.5, 8 Hz, 1H), 1.23 (s, 9H), 1.15 (s, 9H), 0.20 (s, 3H), 0.18 (s, 3H), 0.15 (s, 6H); 13C NMR (CDCl3, $75 \mathrm{MHz}) \delta$ 201.2, 156.4, 153.2, 147.9, 145.3, 139.2, 138.1, 135.1, 130.6 (2C), 129.6, 126.8(2C), 125.2, 122.4, 84.9, 82.3, 76.1, 74.7, 73.2, 44.3, 42.7, 24.9 (6C), $17.8(2 \mathrm{C}),-4.1(2 \mathrm{C}),-4.0$ (2C); IR (film) vmax 3010, 2898, 
1778, 1450, 1209, 955, $802 \mathrm{~cm}-1$; HRMS (ESI) m/z $613.33668\left(\mathrm{MH}+, \mathrm{C}_{34} \mathrm{H}_{53} \mathrm{O}_{6} \mathrm{Si}_{2}\right.$

requires 613.33807).

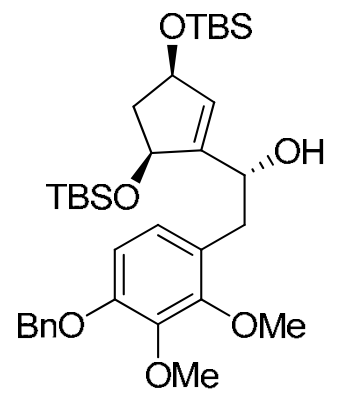

41

\section{(R)-2-(4-(benzyloxy)-2,3-dimethoxyphenyl)-1-((3R,5S)-3,5-bis(tert-}

butyldimethylsilyloxy)cyclopent-1-enyl)ethanol (41). $\mathrm{BH}_{3} \cdot \mathrm{THF}(1.0 \mathrm{M}$ solution in THF, $150 \mu \mathrm{L}, 0.15 \mathrm{mmol})$ was added to the (R)-Corey-Bakshi-Shibata catalyst $(0.038 \mathrm{M}$ solution in THF, $670 \mu \mathrm{L}, 0.0255 \mathrm{mmol}$ ) at $10{ }^{\circ} \mathrm{C}$ under $\mathrm{N}_{2}$. The mixture was treated with a solution of $42(78 \mathrm{mg}, 0.127 \mathrm{mmol})$ in anhydrous THF $(1 \mathrm{~mL})$, stirred at $10^{\circ} \mathrm{C}$ for $3 \mathrm{~h}$, filtered through Celite (washed with $\mathrm{Et}_{2} \mathrm{O}$ ), and concentrated in vacuo. Flash chromatography ( $\mathrm{SiO}_{2}, 1.5 \times 12 \mathrm{~cm}, 5 \%$ EtOAc-hexanes elution) afforded $41(67 \mathrm{mg}$, $0.11 \mathrm{mmol}, 86 \%$ ) as a 7:1 mixture of diastereomers that was a light yellow oil (data for major diastereomer): $[\alpha]^{25}+12.8\left(c 0.79, \mathrm{CH}_{2} \mathrm{Cl}_{2}\right) ;{ }^{1} \mathrm{H} \mathrm{NMR}\left(\mathrm{CDCl}_{3}, 300 \mathrm{MHz}\right) \delta 7.41-$ 7.25(m, 5H), $7.18(\mathrm{~d}, 1 \mathrm{H}, J=8.5 \mathrm{~Hz}), 7.10(\mathrm{~d}, 1 \mathrm{H}, J=8.5 \mathrm{~Hz}), 6.48(\mathrm{~s}, 1 \mathrm{H}), 5.15(\mathrm{~s}, 2 \mathrm{H})$, 4.85-4.81 (m, 1H), 4.66-4.60 (m, 1H), 4.39-4.35 (m, 1H), $3.90(\mathrm{~s}, 3 \mathrm{H}), 3.85(\mathrm{~s}, 3 \mathrm{H})$, 2.91-2.87 (m, 2H), $2.59(\mathrm{dt}, J=12.5,8 \mathrm{~Hz}, 1 \mathrm{H}), 1.75(\mathrm{dt}, J=12.5,8 \mathrm{~Hz}, 1 \mathrm{H}), 1.22(\mathrm{~s}$, 9H), 1.19 (s, 9H), 0.18 (s, 3H), 0.16(s, 3H), 0.14 (s, 6H); ${ }^{13} \mathrm{C} \mathrm{NMR}\left(\mathrm{CDCl}_{3}, 75 \mathrm{MHz}\right) \delta$ $148.2,147.7,143.3,139.7,134.2,129.8,126.0$ (2C), 124.7, 123.5 (2C), 121.9, 118.3, 
84.8, 77.1, 75.2, 68.7, 68.0, 65.4, 62.9, 42.1, 25.1 (6C), 15.8 (2C). $-4.2(2 \mathrm{C}),-4.3(2 \mathrm{C})$; IR (film) $v_{\max } 3011,2858,1621,1522,1187,828 \mathrm{~cm}^{-1}$; HRMS (ESI) $\mathrm{m} / \mathrm{z} 741.24971$ $\left(\mathrm{MH}^{+}, \mathrm{C}_{34} \mathrm{H}_{53} \mathrm{O}_{6} \mathrm{ISi}_{2} \mathrm{H}\right.$ requires 741.24981).

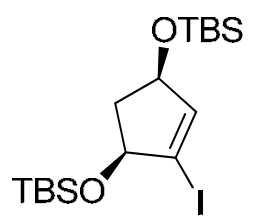

44

(1S,4R)-1,4-di-(tert-butyldimethylsilyloxy)-2-iodocyclopent-2-ene (44). A solution of 56 (1.02 g, $3 \mathrm{mmol})$ in anhydrous $\mathrm{CH}_{2} \mathrm{Cl}_{2}$ at $\mathrm{rt}$ under Ar was treated with DMAP (184 mg, $1.5 \mathrm{mmol})$ and $\mathrm{Et}_{3} \mathrm{~N}(1.95 \mathrm{~mL}, 1.42 \mathrm{~g}, 15 \mathrm{mmol})$, then cooled to $0{ }^{\circ} \mathrm{C}$ and treated with TBS-Cl (743 $\mathrm{mg}, 4.5 \mathrm{mmol})$. The resultant mixture was warmed to $\mathrm{rt}$, stirred under Ar for $12 \mathrm{~h}$, and concentrated in vacuo. Flash chromatography $\left(\mathrm{SiO}_{2}, 2.5 \times\right.$ $14 \mathrm{~cm}, 5 \%$ EtOAc-hexanes elution) afforded $44(1.33 \mathrm{~g}, 2.94 \mathrm{mmol}, 98 \%)$ as a yellow oil: $[\alpha]^{25}+19.2\left(c\right.$ 1.05, $\left.\mathrm{CH}_{2} \mathrm{Cl}_{2}\right) ;{ }^{1} \mathrm{H}$ NMR $\left(\mathrm{CDCl}_{3}, 500 \mathrm{MHz}\right) \delta 6.22-6.19(\mathrm{~m}, 1 \mathrm{H}), 4.59-$ $4.54(\mathrm{~m}, 1 \mathrm{H}), 4.48-4.44(\mathrm{~m}, 1 \mathrm{H}), 2.68-2.63(\mathrm{~m}, 1 \mathrm{H}), 1.72-1.67(\mathrm{~m}, 1 \mathrm{H}), 0.94(\mathrm{~s}, 9 \mathrm{H})$ 0.88 (s, 9H), 0.18 (s, 3H), 0.13 (s, 3H), 0.08 (s, 6H); $\left.{ }^{13} \mathrm{C} \mathrm{NMR} \mathrm{(CDCl} 3,125 \mathrm{MHz}\right) \delta$ 144.1, 106.7, 78.8, 75.6, 44.5, 26.0 (6C), 18.4 (2C), -4.3 (2C), -4.4(2C); IR (film) $v_{\max } 2928$, 2855, 1252, 1087, 835, $776 \mathrm{~cm}^{-1}$; HRMS (ESI) $\mathrm{m} / \mathrm{z} 477.11092\left(\mathrm{MNa}^{+}, \mathrm{C}_{17} \mathrm{H}_{35} \mathrm{O}_{2} \mathrm{ISi}_{2} \mathrm{Na}\right.$ requires 477.11125$)$. 


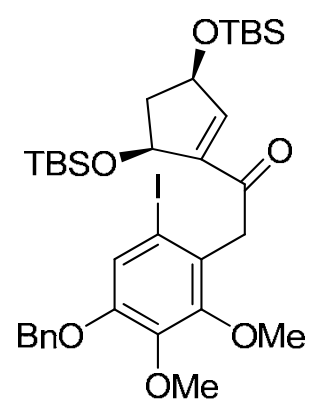

70

\section{2-(4-(benzyloxy)-6-iodo-2,3-dimethoxyphenyl)-1-((3R,5S)-3,5-di-tert-}

butyldimethylsilyloxycyclopent-1-enyl)ethanone (70). A round-bottomed flask under Ar was charged with Mg turnings (264 mg, $11.0 \mathrm{mmol}), \mathrm{LiCl}$ (420 mg, $10.0 \mathrm{mmol})$, and anhydrous THF $(2.5 \mathrm{~mL})$. A solution of $i-\mathrm{PrCl}(0.91 \mathrm{~mL}, 10.0 \mathrm{mmol})$ in anhydrous THF $(2.5 \mathrm{~mL})$ was added dropwise to this mixture at $\mathrm{rt}$. The resultant mixture was stirred at $\mathrm{rt}$ under Ar for $12 \mathrm{~h}$, then transferred to another Ar-filled flask via syringe (this step removed most of the unreacted $\mathrm{Mg}$ ).

A portion of the $i$-PrMgCl$\cdot \mathrm{LiCl}$ prepared above $(2.0 \mathrm{M}$ solution in $\mathrm{THF}, 775 \mu \mathrm{L}$, $1.55 \mathrm{mmol})$ was treated with $15-$ crown-5 $(310 \mu \mathrm{L}, 345 \mathrm{mg}, 1.55 \mathrm{mmol})$. The resultant mixture was added to a solution of $44(217.0 \mathrm{mg}, 0.477 \mathrm{mmol})$ in anhydrous THF $(1 \mathrm{~mL})$ at $0{ }^{\circ} \mathrm{C}$, and the mixture was stirred at $0{ }^{\circ} \mathrm{C}$ for $15 \mathrm{~min}$, then at $\mathrm{rt}$ for $1 \mathrm{~h}$. It was cooled to $-20{ }^{\circ} \mathrm{C}$, and treated with a precooled $\left(-20{ }^{\circ} \mathrm{C}\right)$ solution of $71(203 \mathrm{mg}, 0.43 \mathrm{mmol})$ in

anhydrous THF (1mL). The resultant mixture was stirred at $-20{ }^{\circ} \mathrm{C}$ for $8 \mathrm{~h}$ and at $0{ }^{\circ} \mathrm{C}$ for $4 \mathrm{~h}$, then treated with sat aq $\mathrm{NH}_{4} \mathrm{Cl}(5 \mathrm{~mL})$ and extracted with EtOAc $(3 \times 3 \mathrm{~mL})$. The combined organic layers were dried $\left(\mathrm{MgSO}_{4}\right)$ and concentrated in vacuo. Flash chromatography $\left(\mathrm{SiO}_{2}, 2.5 \times 12 \mathrm{~cm}, 5 \%\right.$ EtOAc-hexanes elution) afforded 70 (187 mg, $0.25 \mathrm{mmol}, 59 \%)$ as a pale yellow oil: $[\alpha]^{25} \mathrm{D}+26.3\left(\right.$ c $\left.1.05, \mathrm{CH}_{2} \mathrm{Cl}_{2}\right) ;{ }^{1} \mathrm{H} \mathrm{NMR}\left(\mathrm{CDCl}_{3}\right.$, 
$300 \mathrm{MHz}) \delta 7.49-7.36(\mathrm{~m}, 5 \mathrm{H}), 7.46(\mathrm{~s}, 1 \mathrm{H}), 6.63(\mathrm{~s}, 1 \mathrm{H}), 5.12(\mathrm{~s}, 2 \mathrm{H}), 4.96-4.91(\mathrm{~m}$, 1H), 4.70-4.65 (m, 1H), 4.20 (s, 2H), $3.91(\mathrm{~s}, 3 \mathrm{H}), 3.86(\mathrm{~s}, 3 \mathrm{H}), 2.73(\mathrm{dt}, J=12.6,6.9 \mathrm{~Hz}$, $1 \mathrm{H}), 1.70(\mathrm{dt}, J=12.6,6.9 \mathrm{~Hz}, 1 \mathrm{H}), 0.94(\mathrm{~s}, 9 \mathrm{H}), 0.88$ (s, 9H), 0.14-0.13 (m, 9H), 0.11 (s, $3 \mathrm{H}) ;{ }^{13} \mathrm{C} \mathrm{NMR}\left(\mathrm{CDCl}_{3}, 75 \mathrm{MHz}\right) \delta 197.2,152.4,147.0,146.2,143.4,142.9,137.4,128.7$ (2C), 128.1, 127.5(2C), 125.3, 109.4, 98.1, 74.2, 73.5, 73.1, 71.2, 61.2, 45.1, 41.6, 26.1 (6C), 18.4 (2C), -4.3 (2C) , -4.6 (2C); IR (film) $v_{\max } 2933,2858,1728,1509,1389,1198$, $1020 \mathrm{~cm}^{-1}$; HRMS (ESI) $\mathrm{m} / \mathrm{z} 761.21357\left(\mathrm{MNa}^{+}, \mathrm{C}_{34} \mathrm{H}_{51} \mathrm{O}_{6} \mathrm{ISi}_{2} \mathrm{Na}\right.$ requires 761.21611$)$.

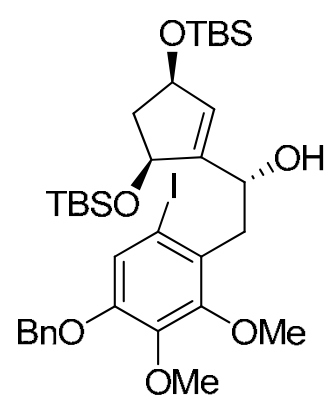

78

(R)-2-(4-(benzyloxy)-6-iodo-2,3-dimethoxyphenyl)-1-((3R,5S)-3,5-di-tert-

butyldimethylsilyloxycyclopent-1-enyl)ethanol (78). $\mathrm{BH}_{3} \cdot \mathrm{THF}(1.0 \mathrm{M}$ solution in THF, $171 \mu \mathrm{L}, 0.17 \mathrm{mmol})$ was added to the $(R)$-Corey-Bakshi-Shibata catalyst $(0.038 \mathrm{M}$ solution in THF, $760 \mu \mathrm{L}, 0.029 \mathrm{mmol}$ ) at $10{ }^{\circ} \mathrm{C}$ under $\mathrm{N}_{2}$. The mixture was treated with a solution of $70(107 \mathrm{mg}, 0.144 \mathrm{mmol})$ in anhydrous THF $(1.5 \mathrm{~mL})$, stirred at $10^{\circ} \mathrm{C}$ for 3 h, filtered through Celite (washed with $\mathrm{Et}_{2} \mathrm{O}$ ), and concentrated in vacuo. Flash chromatography $\left(\mathrm{SiO}_{2}, 2.5 \times 9 \mathrm{~cm}, 5 \%\right.$ EtOAc-hexanes elution) afforded $78(89.5 \mathrm{mg}$, $0.121 \mathrm{mmol}, 84 \%$ ) as a $6.7: 1$ mixture of diastereomers that was a light yellow oil (data for major diastereomer): $[\alpha]^{25}{ }_{\mathrm{D}}+15.9\left(c 0.92, \mathrm{CH}_{2} \mathrm{Cl}_{2}\right) ;{ }^{1} \mathrm{H} \mathrm{NMR}\left(\mathrm{CDCl}_{3}, 300 \mathrm{MHz}\right) \delta$ 7.44-7.27(m, 5H), $7.20(\mathrm{~s}, 1 \mathrm{H}), 6.75(\mathrm{~s}, 1 \mathrm{H}), 5.10(\mathrm{~s}, 2 \mathrm{H}), 4.88-4.82(\mathrm{~m}, 1 \mathrm{H}), 4.63-4.59$ 
(m, 1H), 4.37-4.33 (m, 1H), 3.86(s, 3H), $3.82(\mathrm{~s}, 3 \mathrm{H}), 2.95-2.89(\mathrm{~m}, 2 \mathrm{H}), 2.64(\mathrm{dt}, J=$ 12.6, $6.9 \mathrm{~Hz}, 1 \mathrm{H}), 1.70(\mathrm{dt}, J=12.6,6.9 \mathrm{~Hz}, 1 \mathrm{H}), 1.20(\mathrm{~m}, 9 \mathrm{H}), 1.18(\mathrm{~s}, 9 \mathrm{H}), 0.19$ (s, 3H), $0.16(\mathrm{~s}, 3 \mathrm{H}), 0.14(\mathrm{~s}, 6 \mathrm{H}) ;{ }^{13} \mathrm{C} \mathrm{NMR}\left(\mathrm{CDCl}_{3}, 75 \mathrm{MHz}\right) \delta 147.9,147.5,141.9,138.5$, 133.8, 128.0, $125.1(2 \mathrm{C}), 124.2,123.3(2 \mathrm{C}), 121.4,117.5,96.2,83.1,75.2,74.9,69.2$, 68.5, 65.3, 62.0, 41.7, 23.3 (6C), 15.6 (2C). -4.4 (2C), -4.5 (2C); IR (film) $v_{\max } 2947$, , 2892, 1534, 1251, 1137, 1065, $821 \mathrm{~cm}^{-1}$; HRMS (ESI) $\mathrm{m} / \mathrm{z} 741.24971\left(\mathrm{MH}^{+}\right.$, $\mathrm{C}_{34} \mathrm{H}_{53} \mathrm{O}_{6} \mathrm{ISi}_{2} \mathrm{H}$ requires 741.24981).

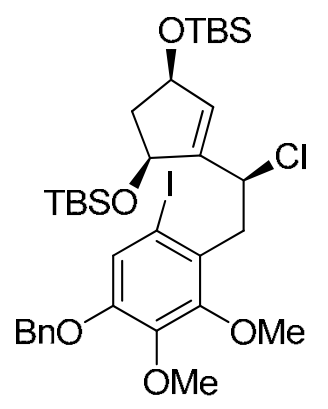

69

\section{(S)-2-(4-(benzyloxy)-6-iodo-2,3-dimethoxyphenyl)-1-((3R,5S)-3,5-di-tert-}

butyldimethylsilyloxycyclopent-1-enyl)-1-chloroethane (69). A solution of 78 (71 mg, $0.095 \mathrm{mmol})$ in anhydrous $\mathrm{CH}_{2} \mathrm{Cl}_{2}(500 \mu \mathrm{L})$ at $0{ }^{\circ} \mathrm{C}$ was treated with anhydrous $\mathrm{Me}_{2} \mathrm{~S}$ (14 $\mu \mathrm{L}, 11.9 \mathrm{mg}, 0.192 \mathrm{mmol})$ and NCS $(15 \mathrm{mg}, 0.114 \mathrm{mmol})$, stirred for 6 hours at $0{ }^{\circ} \mathrm{C}$, and then quenched with sat aq $\mathrm{NH}_{4} \mathrm{Cl}(3 \mathrm{~mL})$ and extracted with EtOAc $(3 \times 3 \mathrm{~mL})$. The combined organic layers were dried $\left(\mathrm{MgSO}_{4}\right)$ and concentrated in vacuo. Flash chromatography $\left(\mathrm{SiO}_{2}, 1.5 \times 12 \mathrm{~cm}, 6 \%\right.$ EtOAc-hexanes elution) afforded $69(31 \mathrm{mg}$, $0.041 \mathrm{mmol})$ as yellow oil: $[\alpha]_{\mathrm{D}}^{25}+25.1\left(\mathrm{c} 1.02, \mathrm{CH}_{2} \mathrm{Cl}_{2}\right) ;{ }^{1} \mathrm{H} \mathrm{NMR}\left(\mathrm{CDCl}_{3}, 300 \mathrm{MHz}\right) \delta$ 7.44-7.29 (m, 5H), $7.27(\mathrm{~s}, 1 \mathrm{H}), 6.60(\mathrm{~s}, 1 \mathrm{H}), 5.08(\mathrm{~s}, 2 \mathrm{H}), 4.88(\mathrm{~m}, 1 \mathrm{H}), 4.65(\mathrm{~m}, 1 \mathrm{H})$, $4.19(\mathrm{~m}, 1 \mathrm{H}), 3.87(\mathrm{~s}, 3 \mathrm{H}), 3.82(\mathrm{~s}, 3 \mathrm{H}), 3.11(\mathrm{~m}, 1 \mathrm{H}), 3.06(\mathrm{~m}, 1 \mathrm{H}), 2.68(\mathrm{dt}, J=12.6$, 
$6.9 \mathrm{~Hz}, 1 \mathrm{H}), 1.65$ (dt, $J=12.6,6.9 \mathrm{~Hz}, 1 \mathrm{H}), 1.21(\mathrm{~s}, 9 \mathrm{H}), 1.18(\mathrm{~s}, 9 \mathrm{H}), 0.24(\mathrm{~s}, 3 \mathrm{H}), 0.19$ $(\mathrm{s}, 6 \mathrm{H}) ;{ }^{13} \mathrm{C} \mathrm{NMR}\left(\mathrm{CDCl}_{3}, 75 \mathrm{MHz}\right) \delta 148.1,147.8,143.0,138.5,132.2,130.8$, 124.5(2C), 122.6, 121.8 (2C), 120.6, 97.8, 71.6, 70.5, 68.4, 68.0, 67.2, 55.6, 40.8, 32.7, 25.2 (6C), 16.2 (2C), -4.4 (2C), -4.3 (2C); IR (film) $v_{\max } 3035,2744,1328,1298,1011$, $952 \mathrm{~cm}^{-1}$; HRMS (ESI) m/z $781.19769\left(\mathrm{MNa}^{+}, \mathrm{C}_{34} \mathrm{H}_{52} \mathrm{CIINaO}_{5} \mathrm{Si}_{2}\right.$ requires 781.19842).<smiles>COc1c(OCc2ccccc2)cc(I)c(CC=O)c1OC</smiles>

76

2-(4-(benzyloxy)-6-iodo-2,3-dimethoxyphenyl)acetaldehyde (76). A solution of (methoxymethyl)triphenylphosphonium chloride $(0.92 \mathrm{~g}, 2.64 \mathrm{mmol})$ in anhydrous THF $(3.0 \mathrm{~mL})$ at $0{ }^{\circ} \mathrm{C}$ was treated dropwise with a solution of KOt-Bu (300 mg, 2.52 mmol) in anhydrous THF $(1.0 \mathrm{~mL})$. The resultant mixture was warmed to rt and stirred under $\mathrm{N}_{2}$ for $30 \mathrm{~min}$, then treated with a solution of 4-benzyloxy-4-iodo-2,3dimethoxybenzaldehyde $(74)^{1}(500 \mathrm{mg}, 1.26 \mathrm{mmol})$ in anhydrous THF $(1.5 \mathrm{~mL})$ and stirred at $\mathrm{rt}$ under $\mathrm{N}_{2}$ for $16 \mathrm{~h}$. The reaction was quenched by the addition of brine $(5 \mathrm{~mL})$, extracted with EtOAc $(3 \times 5 \mathrm{~mL})$, and concentrated in vacuo. The crude enol ether was dissolved in acetone $(5.0 \mathrm{~mL})$, then treated with concentrated $\mathrm{HCl}(1.0 \mathrm{~mL})$ and $\mathrm{H}_{2} \mathrm{O}(1.0$ $\mathrm{mL})$. The resultant mixture was refluxed for $12 \mathrm{~h}$, extracted with $\mathrm{Et}_{2} \mathrm{O}(3 \times 6 \mathrm{~mL})$, dried 
$\left(\mathrm{MgSO}_{4}\right)$, and concentrated in vacuo. Flash chromatography $\left(\mathrm{SiO}_{2}, 1.5 \times 15 \mathrm{~cm}, 10 \%\right.$ EtOAc-hexanes elution) afforded $76(423 \mathrm{mg}, 1.03 \mathrm{mmol}, 82 \%)$ as a colorless oil: ${ }^{1} \mathrm{H}$ NMR $\left(\mathrm{CDCl}_{3}, 500 \mathrm{MHz}\right) \delta 9.74(\mathrm{~s}, 1 \mathrm{H}), 7.48-7.30(\mathrm{~m}, 5 \mathrm{H}), 7.25(\mathrm{~s}, 1 \mathrm{H}), 5.09(\mathrm{~s}, 2 \mathrm{H})$, $3.89(\mathrm{~s}, 2 \mathrm{H}), 3.88(\mathrm{~s}, 3 \mathrm{H}), 3.86(\mathrm{~s}, 3 \mathrm{H}) ;{ }^{13} \mathrm{C} \mathrm{NMR}\left(\mathrm{CDCl}_{3}, 75 \mathrm{MHz}\right) \delta 199.0,153.2,152.6$, 143.4, 136.5, 128.9 (2C), 128.5, 127.7 (2C), 124.1, 120.2, 93.5, 71.5, 61.4, 61.1, 49.8; IR (film) $v_{\max } 2944,2874,1704,1595,1524,1488,1456,1380,1336,1309,1256,1193$, $1116 \mathrm{~cm}^{-1}$; HRMS (ESI) m/z $413.02423\left(\mathrm{MH}^{+}, \mathrm{C}_{17} \mathrm{H}_{17} \mathrm{O}_{4} \mathrm{IH}\right.$ requires 413.02443).<smiles>COc1c(OCc2ccccc2)cc(I)c(CC(=O)N(C)OC)c1OC</smiles>

\section{2-(4-(benzyloxy)-6-iodo-2,3-dimethoxyphenyl)- $N$-methoxy- $N$ -}

methylacetamide (71). A solution of $77(31.0 \mathrm{mg}, 0.075 \mathrm{mmol})$ in $t-\mathrm{BuOH}(0.9 \mathrm{~mL})$ and $\mathrm{H}_{2} \mathrm{O}(0.2 \mathrm{~mL})$ at $\mathrm{rt}$ was treated with 2-methyl-2-butene (100 $\left.\mu \mathrm{L}, 66 \mathrm{mg}, 0.92 \mathrm{mmol}\right)$, $\mathrm{NaH}_{2} \mathrm{PO}_{4}(12 \mathrm{mg}, 0.097 \mathrm{mmol})$, and $\mathrm{NaClO}_{2}(42 \mathrm{mg}, 0.47 \mathrm{mmol})$. The resulting mixture was stirred for $1 \mathrm{~h}$, diluted with $\mathrm{H}_{2} \mathrm{O}(2 \mathrm{~mL})$, and extracted with $\mathrm{CH}_{2} \mathrm{Cl}_{2}(3 \times 4 \mathrm{~mL})$. The combined organic layers were dried $\left(\mathrm{MgSO}_{4}\right)$, and concentrated in vacuo. The crude acid was used directly in the next reaction.

A solution of the carboxylic acid (ca. $0.075 \mathrm{mmol})$ in anhydrous $\mathrm{CH}_{2} \mathrm{Cl}_{2}(0.5 \mathrm{~mL})$ at $0{ }^{\circ} \mathrm{C}$ was treated with $\mathrm{Et}_{3} \mathrm{~N}(12 \mu \mathrm{L}, 8.7 \mathrm{mg}, 0.086 \mathrm{mmol})$ and stirred for $15 \mathrm{~min}$.

\footnotetext{
${ }^{1}$ Jones, S. B.; He, L.; Castle, S. L. Org. Lett. 2006, 868757.
} 
Pivaloyl chloride ( $9 \mu \mathrm{L}, 0.075 \mathrm{mmol}$ ) was then added to the mixture, and it was stirred for $1 \mathrm{~h}$ prior to the addition of $\mathrm{MeO}(\mathrm{Me}) \mathrm{NH} \cdot \mathrm{HCl}(14 \mathrm{mg}, 0.15 \mathrm{mmol})$ and $\mathrm{Et}_{3} \mathrm{~N}(20 \mu \mathrm{L}$, $15 \mathrm{mg}, 0.14 \mathrm{mmol})$. The resultant mixture was stirred at $0{ }^{\circ} \mathrm{C}$ for $2 \mathrm{~h}$, then treated with brine $(0.5 \mathrm{~mL})$ and extracted with $\mathrm{CH}_{2} \mathrm{Cl}_{2}(3 \times 1 \mathrm{~mL})$. The combined organic layers were dried $\left(\mathrm{MgSO}_{4}\right)$, and concentrated in vacuo. Flash chromatography $\left(\mathrm{SiO}_{2}, 0.5 \times 7 \mathrm{~cm}\right.$, 20\% EtOAc-hexanes elution) afforded $71(31.8 \mathrm{mg}, 0.0675 \mathrm{mmol}, 90 \%)$ as a pale yellow solid: ${ }^{1} \mathrm{H}$ NMR $\left(\mathrm{CDCl}_{3}, 300 \mathrm{MHz}\right) \delta$ 7.49-7.37 (m, 5H), $7.25(\mathrm{~s}, 1 \mathrm{H}), 5.09(\mathrm{~s}, 2 \mathrm{H}), 3.98$ (s, 2H), 3.90 (s, 3H), 3.89 (s, 3H), 3.84 (s, 3H), 3.27 (s, 3H); ${ }^{13} \mathrm{C}$ NMR $\left(\mathrm{CDCl}_{3}, 125 \mathrm{MHz}\right)$ $\delta 171.5,152.4,152.3,143.0,136.4,128.5(2 \mathrm{C}), 128.0,127.3(2 \mathrm{C}), 126.2,119.6,93.8$ 71.0, 61.2, 61.1, 60.7, 38.7, 32.4; IR (film) $v_{\max }$ 2936, 1666, 1493, 1467, 1418, 1381, $1275,1258,1194,1090,1044 \mathrm{~cm}^{-1}$; HRMS (ESI) $\mathrm{m} / \mathrm{z} 494.03968\left(\mathrm{MNa}^{+}, \mathrm{C}_{19} \mathrm{H}_{22} \mathrm{O}_{5} \mathrm{NINa}\right.$ requires 494.04349).

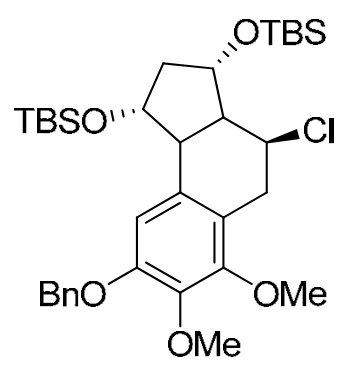

79

((1R,3S,4S)-8-(benzyloxy)-4-chloro-6,7-dimethoxy-2,3,3a,4,5,9b-hexahydro-1Hcyclopenta[a]naphthalene-1,3-diyl)bis(oxy)bis(tert-butyldimethylsilane)

A solution of $69(18 \mathrm{mg}, 0.024 \mathrm{mmol})$ in toluene $(0.5 \mathrm{ml})$ was treated with $\mathrm{Et}_{3} \mathrm{~B}(0.048$ $\mathrm{mL}$ of a $1.0 \mathrm{M}$ solution in hexanes, $0.048 \mathrm{mmol}$ ) at $-30{ }^{\circ} \mathrm{C}$, and a constant supply of dry air was provided by passing compressed air through a short tube of Drierite and over the solution (venting with a needle allowed a continuous flow). An additional portion of 
Et3B $(0.24 \mathrm{~mL}$ of a $1.0 \mathrm{M}$ solution in hexanes, $1.0 \mathrm{mmol})$ was added by syringe pump over $8 \mathrm{~h}$ while the solution was stirred and exposed to dry air as explained above. The solution was stirred for an additional $3 \mathrm{~h}$ then concentrated in vacuo. The residue was purified by flash chromatography $\left(\mathrm{SiO}_{2}, 1.5 \times 10 \mathrm{~cm}, 10 \%\right.$ EtOAc in hexanes elution) to afford 79 (8 mg, $0.0127 \mathrm{mmol}, 53 \%)$ as a yellow oil: $[\alpha]^{25} 31.4\left(c\right.$ 1.0, $\left.\mathrm{CHCl}_{3}\right) ;{ }^{1} \mathrm{H} \mathrm{NMR}$ $\left(\mathrm{CDCl}_{3}, 300 \mathrm{MHz}\right) \delta$ 7.42-7.19 (m, 5H), $6.92(\mathrm{~s}, 1 \mathrm{H}), 4.66-4.59(\mathrm{dd}, J=12.6,7.2 \mathrm{~Hz}$, 1H), $3.91(\mathrm{~s}, 3 \mathrm{H}), 3.84(\mathrm{~s}, 3 \mathrm{H}), 3.58-3.48(\mathrm{~m}, 1 \mathrm{H}), 3.39-3.31(\mathrm{~m}, 1 \mathrm{H}), 3.00(\mathrm{t}, J=7.5 \mathrm{~Hz}$, 1H), $2.83(\mathrm{t}, J=12 \mathrm{~Hz}, 1 \mathrm{H}), 2.69-2.63(\mathrm{dd}, J=12.6,7.2 \mathrm{~Hz}, 1 \mathrm{H}), 2.13-2.04(\mathrm{~m}, 1 \mathrm{H})$, 2.00-1.90 (m, 1H), 1.73-1.62 (m, 1H), $0.97(\mathrm{~s}, 9 \mathrm{H}), 0.91(\mathrm{~s}, 9 \mathrm{H}), 0.11(\mathrm{~s}, 6 \mathrm{H}), 0.08(\mathrm{~s}, 6 \mathrm{H})$ $2.83(\mathrm{dt}, J=13.8,7.2 \mathrm{~Hz}, 1 \mathrm{H}), 1.60(\mathrm{dt}, J=13.8,5.4 \mathrm{~Hz}, 1 \mathrm{H}) 1.20(\mathrm{~s}, 9 \mathrm{H}), 0.99(\mathrm{t}, J=$ $7.8 \mathrm{~Hz}, 9 \mathrm{H}), 0.64$ (q, $J=7.8 \mathrm{~Hz}, 6 \mathrm{H}) ;{ }^{13} \mathrm{C} \mathrm{NMR}\left(\mathrm{CDCl}_{3}, 75 \mathrm{MHz}\right) \delta 155.0,152.1,147.8$, 143.8, 137.8, 133.4, 132.3, 127.6 (2C), 126.9, 126.0 (2C), 75.7, 75.4, 71.5, 71.0, 69.3, 47.7, 43.5, 38.7, 32.4, 27.9, 24.1, 24.1, 16.5, -4.3 (2C), -4.3 (2C); IR (film) $v_{\max } 3521$, 2844, 1652, 1397, $885 \mathrm{~cm}^{-1}$; HRMS (ESI) $\mathrm{m} / \mathrm{z} 633.31854\left(\mathrm{MH}^{+}, \mathrm{C}_{34} \mathrm{H}_{54} \mathrm{ClO}_{5} \mathrm{Si}_{2}\right.$ requires 633.31983).

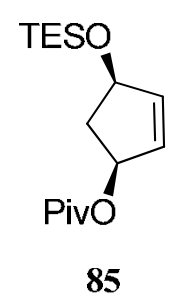

$(1 S, 4 R)$-4-(triethylsilyloxy)cyclopent-2-enyl pivalate (85). A solution of $51^{2}$ (5.30 g, $28.8 \mathrm{mmol})$ in anhydrous $\mathrm{CH}_{2} \mathrm{Cl}_{2}(100 \mathrm{~mL})$ at $\mathrm{rt}$ under $\mathrm{Ar}$ was treated with 
DMAP $(1.80 \mathrm{~g}, 14.7 \mathrm{mmol})$ and $\mathrm{Et}_{3} \mathrm{~N}(20 \mathrm{~mL})$, then cooled to $0{ }^{\circ} \mathrm{C}$ and treated with a solution of chlorotriethylsilane $(9.02 \mathrm{~g}, 59.8 \mathrm{mmol})$ in anhydrous $\mathrm{CH}_{2} \mathrm{Cl}_{2}(20 \mathrm{~mL}$, solution added over a period of $5 \mathrm{~min}$ ). The resultant mixture was warmed to $\mathrm{rt}$ and stirred for $1 \mathrm{~h}$, then diluted with $\mathrm{Et}_{2} \mathrm{O}(30 \mathrm{~mL})$ and washed with brine $(50 \mathrm{~mL})$. The aqueous layer was extracted with EtOAc $(3 \times 100 \mathrm{~mL})$, and the combined organic layers were dried $\left(\mathrm{MgSO}_{4}\right)$ and concentrated in vacuo. Flash chromatography $\left(\mathrm{SiO}_{2}, 5 \times 14 \mathrm{~cm}\right.$, 8\% EtOAc-hexanes elution) afforded 85 (7.75 g, $26.0 \mathrm{mmol}, 90 \%)$ as a colorless oil: $[\alpha]^{25}{ }_{D}-9.5\left(c \quad 1.2, \mathrm{CH}_{2} \mathrm{Cl}_{2}\right) ;{ }^{1} \mathrm{H}$ NMR $\left(\mathrm{CDCl}_{3}, 300 \mathrm{MHz}\right) \delta 6.00-5.98(\mathrm{~m}, 1 \mathrm{H}), 5.91-5.89$ (m, 1H), 5.48-5.44 (m, 1H), 4.76-4.71 (m, 1H), $2.83(\mathrm{dt}, J=13.8,7.2 \mathrm{~Hz}, 1 \mathrm{H}), 1.60(\mathrm{dt}$, $J=13.8,5.4 \mathrm{~Hz}, 1 \mathrm{H}) 1.20(\mathrm{~s}, 9 \mathrm{H}), 0.99(\mathrm{t}, J=7.8 \mathrm{~Hz}, 9 \mathrm{H}), 0.64(\mathrm{q}, J=7.8 \mathrm{~Hz}, 6 \mathrm{H}) ;{ }^{13} \mathrm{C}$ NMR $\left(\mathrm{CDCl}_{3}, 75 \mathrm{MHz}\right) \delta 178.6,138.8,131.9,76.9,74.8,41.5,38.8,27.3$ (3C), 7.0 (3C), 5.0 (3C); IR (film) $v_{\max }$ 2956, 2877, 1728, $1157 \mathrm{~cm}^{-1}$; HRMS (ESI) $\mathrm{m} / \mathrm{z} 321.18496$ $\left(\mathrm{MNa}^{+}, \mathrm{C}_{16} \mathrm{H}_{30} \mathrm{O}_{3} \mathrm{SiNa}\right.$ requires 321.18564$)$.

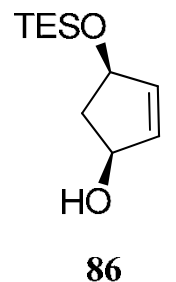

(1S,4R)-4-(triethylsilyloxy)cyclopent-2-enol (86). A solution of 85 (7.75 g, 26.0 mmol) in anhydrous toluene $(50 \mathrm{~mL})$ was cooled to $-78{ }^{\circ} \mathrm{C}$ under $\mathrm{Ar}$ (precipitates formed) and treated with DIBAL-H (1 M solution in toluene, $52 \mathrm{~mL}, 52 \mathrm{mmol})$. The resultant mixture was stirred at $-78{ }^{\circ} \mathrm{C}$ for $2 \mathrm{~h}$, and the reaction was quenched by the addition of

\footnotetext{
${ }^{2}$ Myers, A. G.; Hammond, M.; Wu, Y. Tetrahedron Z\$tt. 1996, 37, 3083.
} 
toluene- $\mathrm{CH}_{3} \mathrm{OH}(1: 1,50 \mathrm{~mL}$, added over a period of $5 \mathrm{~min})$. The mixture was then treated with $1 \mathrm{~N} \mathrm{HCl}(30 \mathrm{~mL})$, stirred for $30 \mathrm{~min}$, and filtered through Celite (washed with EtOAc). The layers were seprated, and the aqueous layer was extracted with EtOAc $(5 \times 50 \mathrm{~mL})$. The combined organic layers were dried $\left(\mathrm{MgSO}_{4}\right)$ and concentrated in vacuo. Flash chromatography $\left(\mathrm{SiO}_{2}, 5 \times 14 \mathrm{~cm}, 15 \%\right.$ EtOAc-hexanes elution) afforded 86 (5.08 g, $23.7 \mathrm{mmol}, 91 \%)$ as a colorless oil: $[\alpha]^{25}{ }_{\mathrm{D}}+17.2\left(\right.$ c 1.4, $\left.\mathrm{CH}_{2} \mathrm{Cl}_{2}\right) ;{ }^{1} \mathrm{H}$ NMR $\left(\mathrm{CDCl}_{3}, 300 \mathrm{MHz}\right) \delta 6.00-5.97(\mathrm{~m}, 1 \mathrm{H}), 5.94-5.91(\mathrm{~m}, 1 \mathrm{H}), 4.70-4.58(\mathrm{~m}, 2 \mathrm{H}), 2.73(\mathrm{dt}$, $J=13.8,7.2 \mathrm{~Hz}, 1 \mathrm{H}), 1.81-1.73(\mathrm{~m}, 1 \mathrm{H}), 1.55(\mathrm{dt}, J=13.8,4.5 \mathrm{~Hz}, 1 \mathrm{H}), 1.00(\mathrm{t}, J=7.8$ $\mathrm{Hz}, 9 \mathrm{H}), 0.65(\mathrm{q}, J=8.1 \mathrm{~Hz}, 6 \mathrm{H}) ;{ }^{13} \mathrm{C} \mathrm{NMR}\left(\mathrm{CDCl}_{3}, 75 \mathrm{MHz}\right) \delta 137.3,135.9,75.5,75.0$, 45.0, 7.0 (3C), 5.0 (3C); IR (film) $v_{\max } 3363,2955,2877,1459,1366,1239 \mathrm{~cm}^{-1}$; HRMS (ESI) $\mathrm{m} / \mathrm{z} 237.12831\left(\mathrm{MNa}^{+}, \mathrm{C}_{11} \mathrm{H}_{22} \mathrm{O}_{2} \mathrm{SiNa}\right.$ requires 237.12813).

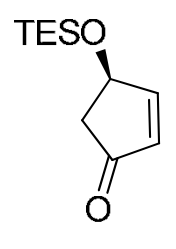

87

(R)-4-(triethylsilyloxy)-cyclopent-2-enone (87). A solution of 86 (5.07 g, 23.6 mmol) in anhydrous $\mathrm{CH}_{2} \mathrm{Cl}_{2}(70 \mathrm{~mL})$ was treated with $\mathrm{NaOAc}(620 \mathrm{mg}, 7.6 \mathrm{mmol})$ and powdered $4 \AA$ molecular sieves $(9.60 \mathrm{~g})$, cooled to $0{ }^{\circ} \mathrm{C}$, and treated with PCC $(7.60 \mathrm{~g}$, $35.2 \mathrm{mmol}$ ). The resultant mixture was warmed to $\mathrm{rt}$ and stirred under Ar for $1 \mathrm{~h}$. The chromium salts were precipitated by the addition of $\mathrm{Et}_{2} \mathrm{O}(300 \mathrm{~mL})$, and the mixture was filtered through Celite and $\mathrm{SiO}_{2}$ (both plugs washed with $200 \mathrm{~mL}$ total of EtOAc). Concentration in vacuo followed by flash chromatography $\left(\mathrm{SiO}_{2}, 5 \times 12 \mathrm{~cm}, 12 \%\right.$ EtOAc-hexanes elution) afforded $87(4.39 \mathrm{~g}, 20.7 \mathrm{mmol}, 87 \%)$ as a yellow oil: $[\alpha]^{25}$ 
$+41.3\left(\right.$ c 1.0, $\left.\mathrm{CH}_{2} \mathrm{Cl}_{2}\right) ;{ }^{1} \mathrm{H} \mathrm{NMR}\left(\mathrm{CDCl}_{3}, 300 \mathrm{MHz}\right) \delta 7.49(\mathrm{dd}, J=5.7,2.4 \mathrm{~Hz}, 1 \mathrm{H}), 6.22$ (dd, $J=5.7,1.5 \mathrm{~Hz}, 1 \mathrm{H}), 5.03-4.99(\mathrm{~m}, 1 \mathrm{H}), 2.75$ (dd, $J=18.3,6.3 \mathrm{~Hz}, 1 \mathrm{H}), 2.29$ (dd, $J$ $=18.3,2.4 \mathrm{~Hz}, 1 \mathrm{H}), 1.02(\mathrm{t}, J=7.8 \mathrm{~Hz}, 9 \mathrm{H}), 0.68(\mathrm{q}, J=7.8 \mathrm{~Hz}, 6 \mathrm{H}) ;{ }^{13} \mathrm{C} \mathrm{NMR}\left(\mathrm{CDCl}_{3}\right.$, $75 \mathrm{MHz}) \delta$ 206.7, 164.1, 134.8, 70.8, 45.3, 6.9 (3C), 4.9 (3C); IR (film) $v_{\max } 2956,2878$, 1725, 1109, $1072 \mathrm{~cm}^{-1}$; HRMS (ESI) $\mathrm{m} / \mathrm{z} 213.13032\left(\mathrm{MH}^{+}, \mathrm{C}_{11} \mathrm{H}_{20} \mathrm{O}_{2} \mathrm{SiH}\right.$ requires 213.13053).

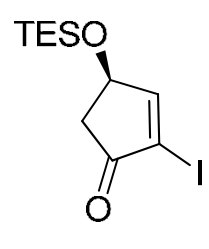

88

(R)-4-(triethylsilyloxy)-2-iodocyclopent-2-enone (88). A solution of 87 (920 $\mathrm{mg}, 4.33 \mathrm{mmol})$ in $\mathrm{CCl}_{4}$-pyridine $(1: 1,30 \mathrm{~mL})$ at $0{ }^{\circ} \mathrm{C}$ under $\mathrm{Ar}$ was treated dropwise with a solution of $\mathrm{I}_{2}(4.6 \mathrm{~g}, 18.2 \mathrm{mmol})$ in $\mathrm{CCl}_{4}$-pyridine $(1: 1,30 \mathrm{~mL})$. The resultant mixture was stirred at $0{ }^{\circ} \mathrm{C}$ for $5 \mathrm{~min}$, then warmed to rt and stirred for $5 \mathrm{~h}$. It was diluted with $\mathrm{Et}_{2} \mathrm{O}(30 \mathrm{~mL})$, washed with $\mathrm{H}_{2} \mathrm{O}(20 \mathrm{~mL}), 1 \mathrm{~N} \mathrm{HCl}(25 \mathrm{~mL})$, sat aq $\mathrm{Na}_{2} \mathrm{~S}_{2} \mathrm{O}_{3}(30$ $\mathrm{mL})$, and sat aq $\mathrm{NaHCO}_{3}(30 \mathrm{~mL})$, dried $\left(\mathrm{MgSO}_{4}\right)$, and concentrated in vacuo. Flash chromatography $\left(\mathrm{SiO}_{2}, 3.5 \times 16 \mathrm{~cm}, 7 \%\right.$ EtOAc-hexanes elution) afforded 88 (1.20 g, $3.55 \mathrm{mmol}, 82 \%)$ as a yellow oil: $[\alpha]^{25}{ }_{\mathrm{D}}+18.5\left(\mathrm{c} 1.6, \mathrm{CH}_{2} \mathrm{Cl}_{2}\right) ;{ }^{1} \mathrm{H}$ NMR $\left(\mathrm{CDCl}_{3}, 300\right.$ MHz) $\delta 7.83(\mathrm{~d}, J=2.4 \mathrm{~Hz}, 1 \mathrm{H}), 5.00-4.95(\mathrm{~m}, 1 \mathrm{H}), 2.90(\mathrm{dd}, J=18.3,6.3 \mathrm{~Hz}, 1 \mathrm{H}), 2.39$ $(\mathrm{dd}, J=18.3,2.1 \mathrm{~Hz}, 1 \mathrm{H}), 1.01(\mathrm{t}, J=8.4 \mathrm{~Hz}, 9 \mathrm{H}), 0.68(\mathrm{q}, J=8.1 \mathrm{~Hz}, 6 \mathrm{H}) ;{ }^{13} \mathrm{C} \mathrm{NMR}$ $\left(\mathrm{CDCl}_{3}, 125 \mathrm{MHz}\right) \delta 200.4,169.3,105.1,72.0,42.5,6.8$ (3C), 4.8 (3C); IR (film) $v_{\max }$ 2955, 2876, 1726, $1086 \mathrm{~cm}^{-1}$; HRMS (ESI) $\mathrm{m} / \mathrm{z} 361.00911\left(\mathrm{MNa}^{+}, \mathrm{C}_{11} \mathrm{H}_{19} \mathrm{O}_{2} \mathrm{ISiNa}\right.$ requires 361.00912). 


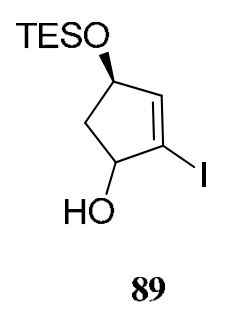

(1S,4R)-2-iodo-4-(triethylsilyloxy)cyclopent-2-enol (89). A solution of $\mathrm{CeCl}_{3} \cdot 7 \mathrm{H}_{2} \mathrm{O}(220 \mathrm{mg}, 0.59 \mathrm{mmol})$ in $\mathrm{CH}_{3} \mathrm{OH}(2.0 \mathrm{~mL})$ was stirred at $\mathrm{rt}$ for $30 \mathrm{~min}$, then treated with a solution of $88(400 \mathrm{mg}, 1.18 \mathrm{mmol})$ in $\mathrm{CH}_{3} \mathrm{OH}(1 \mathrm{~mL})$. The resultant mixture was cooled to $-60{ }^{\circ} \mathrm{C}$, treated with $\mathrm{NaBH}_{4}(45 \mathrm{mg}, 1.18 \mathrm{mmol})$, and stirred at $-30{ }^{\circ} \mathrm{C}$ for $1 \mathrm{~h}$. It was then diluted with $\mathrm{Et}_{2} \mathrm{O}(3 \mathrm{~mL})$ and washed with sat aq $\mathrm{NaHCO}_{3}(3$ $\mathrm{mL})$ and brine $(3 \mathrm{~mL})$. The combined aqueous layers were back-extracted with $\mathrm{Et}_{2} \mathrm{O}(3 \times$ $2 \mathrm{~mL}$ ), and the combined organic layers were dried $\left(\mathrm{MgSO}_{4}\right)$ and concentrated in vacuo. Flash chromatography $\left(\mathrm{SiO}_{2}, 1.5 \times 10 \mathrm{~cm}, 10 \%\right.$ EtOAc-hexanes elution) afforded 89 (290 mg, $0.85 \mathrm{mmol}, 72 \%)$ as a pale yellow oil: $[\alpha]^{25}{ }_{\mathrm{D}}+27.5\left(\right.$ c $\left.0.28, \mathrm{CH}_{2} \mathrm{Cl}_{2}\right) ;{ }^{1} \mathrm{H}$ NMR $\left(\mathrm{CDCl}_{3}, 300 \mathrm{MHz}\right) \delta 6.28(\mathrm{~s}, 1 \mathrm{H}), 4.63-4.58(\mathrm{~m}, 1 \mathrm{H}), 4.51-4.42(\mathrm{~m}, 1 \mathrm{H}), 2.76(\mathrm{dt}, J=$ 13.8, $6.9 \mathrm{~Hz}, 1 \mathrm{H}), 2.57$ (d, $J=7.5 \mathrm{~Hz}, 1 \mathrm{H}), 1.74(\mathrm{dt}, J=13.5,4.8 \mathrm{~Hz}, 1 \mathrm{H}), 0.97$ (t, $J=7.8$ $\mathrm{Hz}, 9 \mathrm{H}), 0.63$ (q, $J=7.8 \mathrm{~Hz}, 6 \mathrm{H}) ;{ }^{13} \mathrm{C} \mathrm{NMR}\left(\mathrm{CDCl}_{3}, 75 \mathrm{MHz}\right) \delta 145.0,106.2,79.7,75.3$, 43.5, 7.0 (3C), 5.0 (3C); IR (film) $v_{\max } 3395,2954,2876,1077,1005 \mathrm{~cm}^{-1}$; HRMS (ESI) $\mathrm{m} / \mathrm{z}$ 363.02374 $\left(\mathrm{MNa}^{+}, \mathrm{C}_{11} \mathrm{H}_{21} \mathrm{O}_{2} \mathrm{ISiNa}\right.$ requires 363.02477).

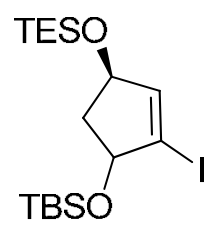

90 


\section{(1S,4R)-1-(tert-butyldimethylsilyloxy)-4-(triethylsilyloxy)2-iodocyclopent-2-}

ene (90). A solution of 89 (721 mg, $2.12 \mathrm{mmol})$ in anhydrous $\mathrm{CH}_{2} \mathrm{Cl}_{2}$ at $\mathrm{rt}$ under $\mathrm{Ar}$ was treated with DMAP $(130 \mathrm{mg}, 1.06 \mathrm{mmol})$ and $\mathrm{Et}_{3} \mathrm{~N}(1.50 \mathrm{~mL}, 1.09 \mathrm{~g}, 10.7 \mathrm{mmol})$, then cooled to $0{ }^{\circ} \mathrm{C}$ and treated with TBS-Cl $(700 \mathrm{mg}, 4.24 \mathrm{mmol})$. The resultant mixture was warmed to $\mathrm{rt}$, stirred under $\mathrm{Ar}$ for $16 \mathrm{~h}$, and concentrated in vacuo. Flash chromatography $\left(\mathrm{SiO}_{2}, 2.5 \times 8 \mathrm{~cm}, 5 \%\right.$ EtOAc-hexanes elution) afforded 90 (940 mg, 2.07 mmol, 98\%) as a yellow oil: $[\alpha]^{25}{ }_{\mathrm{D}}+22.1\left(\mathrm{c} 1.0, \mathrm{CH}_{2} \mathrm{Cl}_{2}\right) ;{ }^{1} \mathrm{H} \mathrm{NMR}\left(\mathrm{CDCl}_{3}, 300\right.$ MHz) $\delta 6.23-6.21(\mathrm{~m}, 1 \mathrm{H}), 4.61-4.54(\mathrm{~m}, 1 \mathrm{H}), 4.51-4.45(\mathrm{~m}, 1 \mathrm{H}), 2.68(\mathrm{dt}, J=12.9,7.2$ $\mathrm{Hz}, 1 \mathrm{H}), 1.73(\mathrm{dt}, J=12.6,6.3 \mathrm{~Hz}, 1 \mathrm{H}), 1.00-0.90(\mathrm{~m}, 9 \mathrm{H}), 0.95(\mathrm{~s}, 9 \mathrm{H}), 0.62(\mathrm{q}, J=8.1$ $\mathrm{Hz}, 6 \mathrm{H}), 0.18$ (s, 3H), 0.12 (s, 3H); ${ }^{13} \mathrm{C} \mathrm{NMR}\left(\mathrm{CDCl}_{3}, 75 \mathrm{MHz}\right) \delta 144.1,106.9,78.9$, 75.4, 44.6, 26.1 (3C), 18.4, 7.0 (3C), 5.0 (3C), -4.2, -4.3; IR (film) $v_{\max } 2955,2877,1251$, $1086 \mathrm{~cm}^{-1}$; HRMS (ESI) $\mathrm{m} / \mathrm{z} 477.11035\left(\mathrm{MNa}^{+}, \mathrm{C}_{17} \mathrm{H}_{35} \mathrm{O}_{2} \mathrm{ISi}_{2} \mathrm{Na}\right.$ requires 477.11125).

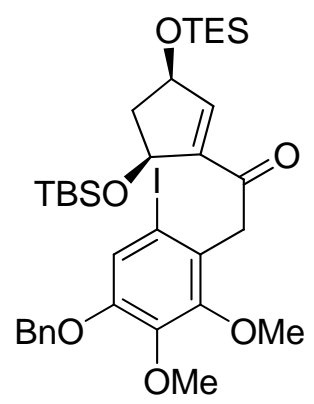

91

\section{2-(4-(benzyloxy)-6-iodo-2,3-dimethoxyphenyl)-1-((3R,5S)-5-tert-} butyldimethylsilyloxy-3-(triethylsilyloxy)cyclopent-1-enyl)ethanone (91). A roundbottomed flask under Ar was charged with $\mathrm{Mg}$ turnings (264 mg, $11.0 \mathrm{mmol}$ ), $\mathrm{LiCl}$ (420 $\mathrm{mg}, 10.0 \mathrm{mmol})$, and anhydrous THF $(2.5 \mathrm{~mL})$. A solution of $i-\operatorname{PrCl}(0.91 \mathrm{~mL}, 10.0$ 
mmol) in anhydrous THF $(2.5 \mathrm{~mL})$ was added dropwise to this mixture at $\mathrm{rt}$. The resultant mixture was stirred at $\mathrm{rt}$ under Ar for $12 \mathrm{~h}$, then transferred to another Ar-filled flask via syringe (this step removed most of the unreacted $\mathrm{Mg}$ ).

A portion of the $i-\mathrm{PrMgCl} \cdot \mathrm{LiCl}$ prepared above $(2.0 \mathrm{M}$ solution in $\mathrm{THF}, 50 \mu \mathrm{L}$, $0.10 \mathrm{mmol})$ was treated with 15 -crown-5 $(20 \mu \mathrm{L}, 22.3 \mathrm{mg}, 0.10 \mathrm{mmol})$. The resultant mixture was added to a solution of $90(14.0 \mathrm{mg}, 0.0308 \mathrm{mmol})$ in anhydrous THF (200 $\mu \mathrm{L}$ ) at $0{ }^{\circ} \mathrm{C}$, and the mixture was stirred at $0{ }^{\circ} \mathrm{C}$ for $10 \mathrm{~min}$, then at $\mathrm{rt}$ for $1 \mathrm{~h}$. It was cooled to $-20{ }^{\circ} \mathrm{C}$, and treated with a precooled $\left(-20^{\circ} \mathrm{C}\right)$ solution of $71(13.1 \mathrm{mg}, 0.0278$ mmol) in anhydrous THF $(200 \mu \mathrm{L})$. The resultant mixture was stirred at $-20{ }^{\circ} \mathrm{C}$ for $2 \mathrm{~h}$ and at $0{ }^{\circ} \mathrm{C}$ for $5 \mathrm{~h}$, then treated with sat aq $\mathrm{NH}_{4} \mathrm{Cl}(1 \mathrm{~mL})$ and extracted with EtOAc $(3 \times$ $2 \mathrm{~mL})$. The combined organic layers were dried $\left(\mathrm{MgSO}_{4}\right)$ and concentrated in vacuo. Flash chromatography $\left(\mathrm{SiO}_{2}, 1.5 \times 7.5 \mathrm{~cm}, 8 \%\right.$ EtOAc-hexanes elution) afforded 91 (12.9 mg, $0.0175 \mathrm{mmol}, 63 \%)$ as a pale yellow oil: $[\alpha]^{25}{ }_{\mathrm{D}}+22.3\left(\right.$ c $\left.1.03, \mathrm{CH}_{2} \mathrm{Cl}_{2}\right) ;{ }^{1} \mathrm{H}$ NMR $\left(\mathrm{CDCl}_{3}, 300 \mathrm{MHz}\right) \delta$ 7.49-7.34 (m, 5H), $7.41(\mathrm{~s}, 1 \mathrm{H}), 6.81(\mathrm{~s}, 1 \mathrm{H}), 5.12(\mathrm{~s}, 2 \mathrm{H})$, 4.96-4.91 (m, 1H), 4.70-4.65 (m, 1H), $4.00(\mathrm{~s}, 2 \mathrm{H}), 3.90(\mathrm{~s}, 3 \mathrm{H}), 3.86(\mathrm{~s}, 3 \mathrm{H}), 2.74$ (dt, J $=13.2,7.5 \mathrm{~Hz}, 1 \mathrm{H}), 1.71(\mathrm{dt}, J=13.2,6.0 \mathrm{~Hz}, 1 \mathrm{H}), 1.19-1.09(\mathrm{~m}, 9 \mathrm{H}), 1.14(\mathrm{~s}, 9 \mathrm{H}), 0.72$ $(\mathrm{q}, J=8.1 \mathrm{~Hz}, 6 \mathrm{H}), 0.18(\mathrm{~s}, 3 \mathrm{H}), 0.12(\mathrm{~s}, 3 \mathrm{H}) ;{ }^{13} \mathrm{C} \mathrm{NMR}\left(\mathrm{CDCl}_{3}, 75 \mathrm{MHz}\right) \delta 197.2,153.2$, $152.4,147.1,143.4,137.4,137.1,128.8(2 \mathrm{C}), 128.1,127.5(2 \mathrm{C}), 125.3,121.8,97.1,80.0$, 79.5, 73.5, 73.1, 71.2, 45.2, 43.7, 26.1 (3C), 18.4, 8.7 (3C), 6.1 (3C), -4.3, -4.4; IR (film) $v_{\max } 2928,2855,2360,1685,1493,1469,1362,1253,1087 \mathrm{~cm}^{-1} ;$ HRMS (ESI) $\mathrm{m} / \mathrm{z}$ 761.21196 $\left(\mathrm{MNa}^{+}, \mathrm{C}_{34} \mathrm{H}_{51} \mathrm{O}_{6} \mathrm{ISi}_{2} \mathrm{Na}\right.$ requires 761.21611). 


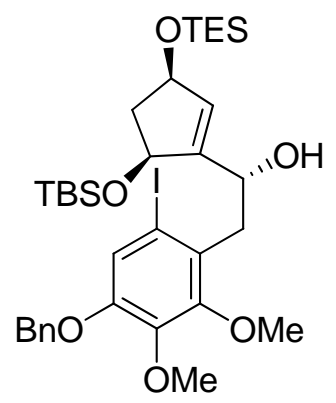

92

(R)-2-(4-(benzyloxy)-6-iodo-2,3-dimethoxyphenyl)-1-((3R,5S)-5-tertbutyldimethylsilyloxy-3-(triethylsilyloxy)cyclopent-1-enyl)ethanol (92). $\mathrm{BH}_{3} \cdot \mathrm{THF}$ (1.0 M solution in THF, $16 \mu \mathrm{L}, 0.016 \mathrm{mmol}$ ) was added to the $(R)$-Corey-Bakshi-Shibata catalyst $(0.038 \mathrm{M}$ solution in THF, $71 \mu \mathrm{L}, 0.0027 \mathrm{mmol})$ at $10{ }^{\circ} \mathrm{C}$ under $\mathrm{N}_{2}$. The mixture was treated with a solution of $91(10.0 \mathrm{mg}, 0.0135 \mathrm{mmol})$ in anhydrous THF $(500 \mu \mathrm{L})$, stirred at $10{ }^{\circ} \mathrm{C}$ for $3 \mathrm{~h}$, filtered through Celite (washed with $\mathrm{Et}_{2} \mathrm{O}$ ), and concentrated in vacuo. Flash chromatography $\left(\mathrm{SiO}_{2}, 1.5 \times 7.5 \mathrm{~cm}, 5 \%\right.$ EtOAc-hexanes elution) afforded $92(9.2 \mathrm{mg}, 0.0125 \mathrm{mmol}, 92 \%)$ as a 9:1 mixture of diastereomers that was a light yellow oil (data for major diastereomer): $[\alpha]^{25}{ }_{\mathrm{D}}+10.3\left(c \mathrm{c} 0.78, \mathrm{CH}_{2} \mathrm{Cl}_{2}\right) ;{ }^{1} \mathrm{H} \mathrm{NMR}\left(\mathrm{CDCl}_{3}, 300\right.$ MHz) $\delta 7.38-7.23(\mathrm{~m}, 5 \mathrm{H}), 7.18(\mathrm{~s}, 1 \mathrm{H}), 6.70(\mathrm{~s}, 1 \mathrm{H}), 5.01(\mathrm{~s}, 2 \mathrm{H}), 4.85-4.80(\mathrm{~m}, 1 \mathrm{H})$, 4.59-4.55 (m, 1H), 4.35-4.31 (m, 1H), $3.80(\mathrm{~s}, 3 \mathrm{H}), 3.79(\mathrm{~s}, 3 \mathrm{H}), 2.90-2.83(\mathrm{~m}, 2 \mathrm{H})$, $2.63(\mathrm{dt}, J=13.2,7.2 \mathrm{~Hz}, 1 \mathrm{H}), 1.96(\mathrm{~s}, 1 \mathrm{H}), 1.60(\mathrm{dt}, J=13.2,5.7 \mathrm{~Hz}, 1 \mathrm{H}), 1.27-1.16(\mathrm{~m}$, $9 \mathrm{H}), 1.21(\mathrm{~s}, 9 \mathrm{H}), 0.79(\mathrm{q}, J=7.8 \mathrm{~Hz}, 6 \mathrm{H}), 0.24(\mathrm{~s}, 3 \mathrm{H}), 0.20(\mathrm{~s}, 3 \mathrm{H}) ;{ }^{13} \mathrm{C} \mathrm{NMR}\left(\mathrm{CDCl}_{3}\right.$, $75 \mathrm{MHz}) \delta 148.3,148.1,142.8,139.1,133.2,128.6,124.7$ (2C), 124.2, $124.0(2 \mathrm{C}), 121.8$, $117.7,95.4,82.8,75.8,75.3,69.5,69.0,66.5,61.1,40.9,22.1$ (3C), 13.9, 9.7 (3C), 6.5 (3C), -4.4, -4.5; IR (film) $v_{\max } 3129,2958,2913,2878,1532,1433,1289,1110,1072$ $\mathrm{cm}^{-1}$; HRMS (ESI) m/z 741.25032 $\left(\mathrm{MH}^{+}, \mathrm{C}_{34} \mathrm{H}_{53} \mathrm{O}_{6} \mathrm{ISi}_{2} \mathrm{H}\right.$ requires 741.24981). 


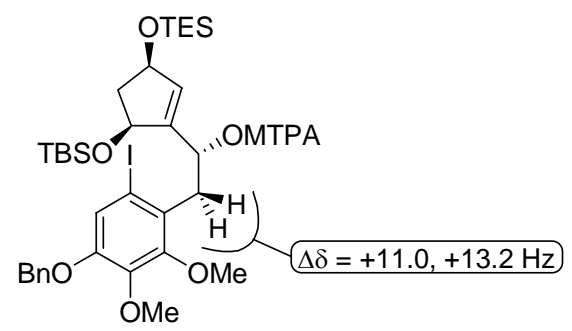

Analysis of MTPA ester of 92.

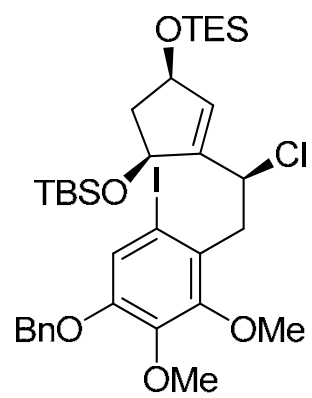

93

(S)-2-(4-(benzyloxy)-6-iodo-2,3-dimethoxyphenyl)-1-((3R,5S)-5-tert-

butyldimethylsilyloxy-3-(triethylsilyloxy)cyclopent-1-enyl)-1-chloroethane (93). A solution of $92(6.0 \mathrm{mg}, 0.0081 \mathrm{mmol})$ in anhydrous $\mathrm{CH}_{2} \mathrm{Cl}_{2}(100 \mu \mathrm{L})$ at $-25{ }^{\circ} \mathrm{C}$ was treated with anhydrous $\mathrm{Et}_{3} \mathrm{~N}(1.0 \mu \mathrm{L}, 0.73 \mathrm{mg}, 0.0072 \mathrm{mmol})$, stirred for $10 \mathrm{~min}$, and then treated with methanesulfonyl chloride $(1.5 \mu \mathrm{L}, 2.2 \mathrm{mg}, 0.019 \mathrm{mmol})$. The resultant mixture was slowly warmed to $0{ }^{\circ} \mathrm{C}$ and stirred under $\mathrm{Ar}$ for $4 \mathrm{~h}$, then concentrated in vacuo. Flash chromatography $\left(\mathrm{SiO}_{2}, 1.5 \times 7.5 \mathrm{~cm}, 8 \%\right.$ EtOAc-hexanes elution) afforded $93(4.0 \mathrm{mg}, 0.0053 \mathrm{mmol}, 65 \%)$ as a pale yellow oil: $[\alpha]^{25}{ }_{\mathrm{D}}+39.4\left(\mathrm{c} 1.14, \mathrm{CH}_{2} \mathrm{Cl}_{2}\right) ;{ }^{1} \mathrm{H}$ NMR $\left(\mathrm{CDCl}_{3}, 300 \mathrm{MHz}\right) \delta 7.42-7.27(\mathrm{~m}, 5 \mathrm{H}), 7.22(\mathrm{~s}, 1 \mathrm{H}), 6.56(\mathrm{~s}, 1 \mathrm{H}), 5.03(\mathrm{~s}, 2 \mathrm{H})$, $4.85(\mathrm{t}, J=6.6 \mathrm{~Hz}, 1 \mathrm{H}), 4.61(\mathrm{t}, J=6.3 \mathrm{~Hz}, 1 \mathrm{H}), 4.16(\mathrm{t}, J=5.7 \mathrm{~Hz}, 1 \mathrm{H}), 3.83(\mathrm{~s}, 3 \mathrm{H})$, $3.79(\mathrm{~s}, 3 \mathrm{H}), 3.09(\mathrm{~d}, J=5.7 \mathrm{~Hz}, 1 \mathrm{H}), 3.02(\mathrm{~d}, J=5.4 \mathrm{~Hz}, 1 \mathrm{H}), 2.68(\mathrm{dt}, J=11.4,6.0 \mathrm{~Hz}$, 1H), 1.65 (dt, $J=11.7,5.7 \mathrm{~Hz}, 1 \mathrm{H}), 1.27-1.17(\mathrm{~m}, 9 \mathrm{H}), 1.21(\mathrm{~s}, 9 \mathrm{H}), 0.79$ (q, $J=6.6 \mathrm{~Hz}$, 
6H), $0.24(\mathrm{~s}, 3 \mathrm{H}), 0.19(\mathrm{~s}, 3 \mathrm{H}) ;{ }^{13} \mathrm{C} \mathrm{NMR}\left(\mathrm{CDCl}_{3}, 75 \mathrm{MHz}\right) \delta$ 147.4, 147.2, 142.1, 137.9, 132.4, 130.1, $123.8(2 \mathrm{C}), 123.1(2 \mathrm{C}), 122.5$ (2C), 120.2, 96.6, 72.0, 71.9, 69.2, 68.5, 68.0, 56.0, 40.1, 36.6, 21.1 (3C), 13.3, 9.5 (3C), 6.0 (3C), -4.5, -4.6; IR (film) $v_{\max } 2928,2856$, 1252, $1087 \mathrm{~cm}^{-1}$; HRMS (ESI) $\mathrm{m} / \mathrm{z} 776.24489\left(\mathrm{M}\left(\mathrm{NH}_{4}\right)^{+}, \mathrm{C}_{34} \mathrm{H}_{52} \mathrm{O}_{5} \mathrm{ClISi}_{2} \mathrm{NH}_{4}\right.$ requires 776.24247).

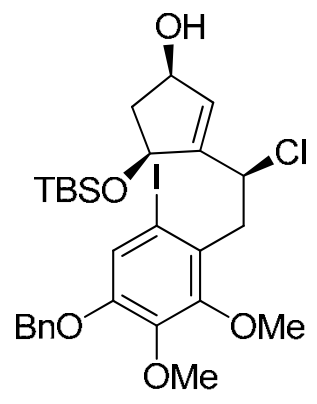

94

(1R,4S)-3-((S)-2-(4-(benzyloxy)-6-iodo-2,3-dimethoxyphenyl)-1-chloroethyl)4-(tert-butyldimethylsilyloxy)cyclopent-2-enol (94). A solution of 93 (10.0 mg, 0.013 mmol) in anhydrous THF $(500 \mu \mathrm{L})$ at $0{ }^{\circ} \mathrm{C}$ was treated with HF pyridine $(1.2 \mathrm{M}$ solution in THF, $10 \mu \mathrm{L}, 0.12 \mathrm{mmol}$ ), stirred at $0{ }^{\circ} \mathrm{C}$ for $30 \mathrm{~min}$, then warmed to rt and stirred for 30 min. The resultant mixture was diluted with EtOAc $(2 \mathrm{~mL})$, treated with sat aq $\mathrm{NaHCO}_{3}(1 \mathrm{~mL})$, extracted with EtOAc $(3 \times 1 \mathrm{~mL})$, dried $\left(\mathrm{MgSO}_{4}\right)$, and concentrated in vacuo. Flash chromatography $\left(\mathrm{SiO}_{2}, 1.5 \times 6 \mathrm{~cm}, 15 \%\right.$ EtOAc-hexanes elution) afforded 94 (6.1 mg, $0.0095 \mathrm{mmol}, 72 \%)$ as a light yellow oil: $[\alpha]^{25}+31.0\left(c 1.00, \mathrm{CH}_{2} \mathrm{Cl}_{2}\right) ;{ }^{1} \mathrm{H}$ NMR $\left(\mathrm{CDCl}_{3}, 300 \mathrm{MHz}\right) \delta$ 7.49-7.34 (m, 5H), $7.29(\mathrm{~s}, 1 \mathrm{H}), 6.64(\mathrm{~s}, 1 \mathrm{H}), 5.13(\mathrm{~s}, 2 \mathrm{H})$, 4.96-4.92 (m, 1H), 4.69-4.63 (m, 1H), 4.18-4.14 (m, 1H), $3.91(\mathrm{~s}, 3 \mathrm{H}), 3.87(\mathrm{~s}, 3 \mathrm{H})$, $3.08(\mathrm{~d}, J=4.8 \mathrm{~Hz}, 1 \mathrm{H}), 3.02(\mathrm{~d}, J=5.4 \mathrm{~Hz}, 1 \mathrm{H}), 2.77-2.67(\mathrm{~m}, 1 \mathrm{H}), 2.01(\mathrm{~s}, 1 \mathrm{H}), 1.75-$ $1.67(\mathrm{~m}, 1 \mathrm{H}), 0.89(\mathrm{~s}, 9 \mathrm{H}), 0.14(\mathrm{~s}, 3 \mathrm{H}), 0.10(\mathrm{~s}, 3 \mathrm{H}) ;{ }^{13} \mathrm{C} \mathrm{NMR}\left(\mathrm{CDCl}_{3}, 75 \mathrm{MHz}\right) \delta 150.3$, 
145.0, 141.3, 140.9, 135.4, 126.7 (2C), 126.0, 125.5 (2C), 123.2, 119.5, 107.4, 98.2, 71.5, 71.0, 69.1, 59.1, 59.0, 43.1, 39.6, 27.9, 24.0 (3C), 16.4, -4.4, -4.5; IR (film) $v_{\max } 3395$, 2954, 2911, 2876, 2360, 1605, 1458, 1414, 1355, 1290, 1239, 1117, $1077 \mathrm{~cm}^{-1}$. HRMS (ESI) $\mathrm{m} / \mathrm{z} 662.15397\left(\mathrm{M}\left(\mathrm{NH}_{4}\right)^{+}, \mathrm{C}_{28} \mathrm{H}_{42} \mathrm{ClINO}_{5} \mathrm{Si}+\right.$ requires 662.15600).

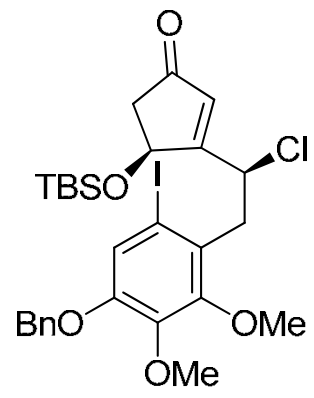

35

(S)-3-((S)-2-(4-(benzyloxy)-6-iodo-2,3-dimethoxyphenyl)-1-chloroethyl)-4-

(tert-butyldimethylsilyloxy)cyclopent-2-enone (35). A solution of $94(5.0 \mathrm{mg}, 0.0078$ mmol) in anhydrous $\mathrm{CH}_{2} \mathrm{Cl}_{2}(100 \mu \mathrm{L})$ was treated with anhydrous $\mathrm{NaOAc}(2.5 \mathrm{mg}, 0.034$ mmol) and $4 \AA \mathrm{MS}(37 \mathrm{mg})$, then cooled to $0{ }^{\circ} \mathrm{C}$ and treated with pyridinium chlorochromate (33 mg, $0.15 \mathrm{mmol}$ ). The resultant mixture was warmed to rt and stirred for $30 \mathrm{~min}$, then treated with $\mathrm{Et}_{2} \mathrm{O}(1 \mathrm{~mL})$, extracted with $\mathrm{Et}_{2} \mathrm{O}(3 \times 1 \mathrm{~mL})$, filtered through Celite (washed with $\left.\mathrm{Et}_{2} \mathrm{O}\right)$, dried $\left(\mathrm{MgSO}_{4}\right)$, and concentrated in vacuo. Flash chromatography ( $\mathrm{SiO}_{2}, 1.5 \times 6 \mathrm{~cm}, 6 \%$ EtOAc-hexanes elution) afforded 35 (4.4 mg, $0.0068 \mathrm{mmol}, 88 \%)$ as a colorless oil: $[\alpha]^{25}+10.7\left(c 0.56, \mathrm{CH}_{2} \mathrm{Cl}_{2}\right) ;{ }^{1} \mathrm{H}$ NMR $\left(\mathrm{CDCl}_{3}\right.$, $300 \mathrm{MHz}) \delta 7.46-7.31(\mathrm{~m}, 6 \mathrm{H}), 6.80(\mathrm{~s}, 1 \mathrm{H}), 5.09(\mathrm{~s}, 2 \mathrm{H}), 4.93-4.89(\mathrm{~m}, 1 \mathrm{H}), 4.32-4.27$ (m, 1H), 3.88 (s, 3H), 3.82 (s, 3H), $3.25(\mathrm{~d}, J=6.6 \mathrm{~Hz}, 1 \mathrm{H}), 3.20$ (d, $J=6.9 \mathrm{~Hz}, 1 \mathrm{H})$, $2.75(\mathrm{~d}, J=7.2 \mathrm{~Hz}, 1 \mathrm{H}), 1.69(\mathrm{~d}, J=6.9 \mathrm{~Hz}, 1 \mathrm{H}), 0.91(\mathrm{~s}, 9 \mathrm{H}), 0.08(\mathrm{~s}, 3 \mathrm{H}), 0.00(\mathrm{~s}, 3 \mathrm{H})$; 
${ }^{13} \mathrm{C}$ NMR $\left(\mathrm{CDCl}_{3}, 75 \mathrm{MHz}\right) \delta 202.5,157.2,147.7,147.6,142.5,138.7,132.8,124.1$ (2C), $123.5,122.9$ (2C), 120.6, 111.6, 95.7, 72.3, 68.9, 68.4, 66.6, 56.6, 40.5, 37.0, 21.5 (3C), 13.8, -5.0, -5.1; IR (film) $v_{\max } 2955,2876,1726,1274,1167,1086 \mathrm{~cm}^{-1}$; HRMS (ESI) $\mathrm{m} / \mathrm{z} 643.11247\left(\mathrm{MH}^{+}, \mathrm{C}_{28} \mathrm{H}_{36} \mathrm{O}_{5} \mathrm{ClISiH}\right.$ requires 643.11380).

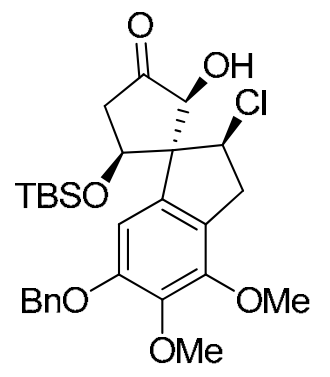

36

a-Hydroxy ketone 97: A solution of 35 (7.0 mg, $0.011 \mathrm{mmol})$ in anhydrous THF $(100 \mu \mathrm{L})$ at $0{ }^{\circ} \mathrm{C}$ was treated with hexabutylditin $(5.8 \mu \mathrm{L}, 6.7 \mathrm{mg}, 0.011 \mathrm{mmol})$ and triethylaluminum (1.0 M solution in THF, $32 \mu \mathrm{L}, 0.032 \mathrm{mmol})$. The resultant mixture was irradiated at $0{ }^{\circ} \mathrm{C}$ with a sunlamp for $6 \mathrm{~h}$ (frequent addition of ice to the cooling bath was necessary to maintain this temperature). Then, 3-phenyl-2-(phenylsulfonyl)oxaziridine $^{3}$ (ca. $0.5 \mathrm{M}$ solution in THF, $100 \mu \mathrm{L}, 0.05 \mathrm{mmol}$ ) was added to the mixture, and it was stirred at $0{ }^{\circ} \mathrm{C}$ (without irradiation) for $5 \mathrm{~h}$, then at rt for $2 \mathrm{~h}$. The resultant mixture was extracted with EtOAc $(3 \times 0.5 \mathrm{~mL})$, dried $\left(\mathrm{MgSO}_{4}\right)$, and concentrated in vacuo. Flash chromatography $\left(\mathrm{SiO}_{2}, 1.5 \times 9 \mathrm{~cm}, 10-15 \%\right.$ EtOAc in hexanes gradient elution) afforded $96(3.6 \mathrm{mg}, 0.0067 \mathrm{mmol}, 62 \%)$ as a colorless oil: $[\alpha]^{25}+26(c 0.23$, $\left.\mathrm{CH}_{2} \mathrm{Cl}_{2}\right) ;{ }^{1} \mathrm{H}$ NMR $\left(\mathrm{CDCl}_{3}, 300 \mathrm{MHz}\right) \delta 7.53-7.32(\mathrm{~m}, 6 \mathrm{H}), 5.06(\mathrm{~s}, 2 \mathrm{H}), 4.82(\mathrm{t}, J=7.2$ 
$\mathrm{Hz}, 1 \mathrm{H}), 4.45$ (t, $J=6.6 \mathrm{~Hz}, 1 \mathrm{H}), 4.25(\mathrm{~s}, 1 \mathrm{H}), 3.90(\mathrm{~s}, 3 \mathrm{H}), 3.84$ (s, 3H), 2.99 (d, $J=6.9$ Hz, 1H), $2.91(\mathrm{~d}, J=6.6 \mathrm{~Hz}, 1 \mathrm{H}), 2.62(\mathrm{~d}, J=6.9 \mathrm{~Hz}, 1 \mathrm{H}), 2.11(\mathrm{~d}, J=7.2 \mathrm{~Hz}, 1 \mathrm{H}), 1.51$ (br s, 1H), 0.88 (s, 9H), 0.13 (s, 3H), $0.11(\mathrm{~s}, 3 \mathrm{H}) ;{ }^{13} \mathrm{C} \mathrm{NMR}\left(\mathrm{CDCl}_{3}, 75 \mathrm{MHz}\right) \delta 207.5$, 149.7, 149.6, 146.4, 142.5, 134.8, 127.8 (2C), 127.3, 126.4 (2C), 121.8, 103.4, 92.2, 72.1, 66.2, 64.2, 63.8, 63.1, 49.7, 42.7, 38.8, 22.2 (3C) $, 16.1,-4.9,-5.0$; DEPT NMR $\left(\mathrm{CDCl}_{3}\right.$, 75 MHz) C: 207.5, 149.7, 149.6, 146.4, 142.5, 134.8, 121.8, 64.2, 16.1 CH: 127.8, 127.3, 126.4, 103.4, 92.2, 66.2, $49.7 \mathbf{C H}_{2}: 72.1,42.7,38.8 \mathbf{C H}_{3}: 63.8,63.1,22.2,-4.9, \quad-5.0$; 2D ${ }^{1} \mathrm{H}-{ }^{1} \mathrm{H}$ COSY NMR $\left(\mathrm{CDCl}_{3}, 500 \mathrm{MHz}\right) 4.82 / 2.62$ (s), 4.82/2.11 (s), 4.45/2.99 (s), 4.45/2.91 (s); 2D ${ }^{1} \mathrm{H}-{ }^{13} \mathrm{C}$ HMQC NMR ( $\left.\mathrm{CDCl}_{3}, 500 \mathrm{MHz}\right) 7.53-7.32 / 127.8$, 7.537.32/127.3, 7.53-7.32/126.4, 7.53-7.32/103.4, 5.06/72.1, 4.82/66.2, 4.45/49.7, 4.25/92.2, 3.90 and $3.84 / 63.8$ and $63.1,2.99 / 38.8,2.91 / 38.8,2.62 / 42.7,2.11 / 42.7,0.88 / 22.2,0.13$ and 0.11/-4.9 and -5.0; IR (film) $v_{\max } 3012,2955,2878,2857,1728,1471,1356,1251$, 1134, $1087 \mathrm{~cm}^{-1}$; HRMS (ESI) $\mathrm{m} / \mathrm{z} 533.21177\left(\mathrm{MH}^{+}, \mathrm{C}_{28} \mathrm{H}_{37} \mathrm{O}_{6} \mathrm{ClSiH}\right.$ requires $533.21207)$.

The iodide 95 (0.5 mg, $0.00076 \mathrm{mmol}, 7 \%)$ and reduced compound 96 (0.2 mg, $0.00037 \mathrm{mmol}, 3 \%)$ were also obtained. For 95: ${ }^{1} \mathrm{H} \mathrm{NMR}\left(\mathrm{CDCl}_{3}, 300 \mathrm{MHz}\right) \delta 7.49-$ $7.34(\mathrm{~m}, 6 \mathrm{H}), 5.13(\mathrm{~s}, 2 \mathrm{H}), 4.98-4.92(\mathrm{~m}, 1 \mathrm{H}), 4.72-4.63(\mathrm{~m}, 1 \mathrm{H}), 4.59(\mathrm{~s}, 1 \mathrm{H}), 3.91(\mathrm{~s}$, 3H), 3.87 (s, 3H), 3.00 (d, $J=6.6 \mathrm{~Hz}, 1 \mathrm{H}), 2.93$ (d, $J=6.6 \mathrm{~Hz}, 1 \mathrm{H}), 2.65$ (d, $J=6.6 \mathrm{~Hz}$, 1H), $2.02(\mathrm{~d}, J=6.9 \mathrm{~Hz}, 1 \mathrm{H}), 0.89(\mathrm{~s}, 9 \mathrm{H}), 0.14(\mathrm{~s}, 6 \mathrm{H}) ;{ }^{13} \mathrm{C} \mathrm{NMR}\left(\mathrm{CDCl}_{3}, 75 \mathrm{MHz}\right) \delta$ 202.1, 146.3, 146.2, 144.4, 139.1, 139.0, 120.8 (2C), 120.1 (2C), 119.5, 113.6, 91.4, 71.2,

\footnotetext{
${ }^{3}$ Davis, F. A.; Vishawakarma, L. C.; Billmers, J. G.; Finn, J. J. Org. Chem. 1984, 49, 3241.
} 
67.1, 63.9, 63.5, 63.0, 53.2, 47.4, 41.1, 37.3, 22.0 (3C), 14.4, -4.4, -4.5; HRMS (ESI) $\mathrm{m} / \mathrm{z}$ $643.11245\left(\mathrm{MH}^{+}, \mathrm{C}_{28} \mathrm{H}_{36} \mathrm{O}_{5} \mathrm{ClISiH}\right.$ requires 643.11380). For 96: ${ }^{1} \mathrm{H} \mathrm{NMR}\left(\mathrm{CDCl}_{3}, 300\right.$ MHz) $\delta ~ 7.46-7.31(\mathrm{~m}, 6 \mathrm{H}), 5.10(\mathrm{~s}, 2 \mathrm{H}), 4.93-4.88(\mathrm{~m}, 1 \mathrm{H}), 4.65(\mathrm{t}, J=6.3 \mathrm{~Hz}, 1 \mathrm{H})$, $3.88(\mathrm{~s}, 3 \mathrm{H}), 3.84(\mathrm{~s}, 3 \mathrm{H}), 2.92(\mathrm{~d}, J=6.6 \mathrm{~Hz}, 1 \mathrm{H}), 2.85(\mathrm{~d}, J=6.6 \mathrm{~Hz}, 1 \mathrm{H}), 2.65(\mathrm{~d}, J=$ $6.9 \mathrm{~Hz}, 1 \mathrm{H}), 2.49$ (s, 1H), 2.05 (s, 1H), $2.00(\mathrm{~d}, J=6.9 \mathrm{~Hz}, 1 \mathrm{H}), 0.92(\mathrm{~s}, 9 \mathrm{H}), 0.11(\mathrm{~s}, 6 \mathrm{H})$; ${ }^{13} \mathrm{C} \mathrm{NMR}\left(\mathrm{CDCl}_{3}, 125 \mathrm{MHz}\right) \delta 208.2,145.4,144.1,143.8,142.6,139.8,120.1$ (2C), $118.8,118.3(2 \mathrm{C}), 114.4,96.5,73.0,69.6,65.5,63.9,62.7,51.2,40.6,40.0,39.2,25.8$ (3C), 17.6, -4.3, -4.4; HRMS (ESI) $\mathrm{m} / \mathrm{z} 534.23974\left(\mathrm{M}\left(\mathrm{NH}_{4}\right)^{+}, \mathrm{C}_{28} \mathrm{H}_{37} \mathrm{O}_{5} \mathrm{ClSiNH}_{4}\right.$ requires 534.24370).

Conversion of 95 into 36 . A solution of $95(9.6 \mathrm{mg}, 0.015 \mathrm{mmol})$ in anhydrous THF $(200 \mu \mathrm{L})$ at $0{ }^{\circ} \mathrm{C}$ was treated with $\mathrm{Et}_{2} \mathrm{Zn}(1.0 \mathrm{M}$ solution in hexane, $45 \mu \mathrm{L}, 0.045$ mmol) and stirred vigorously under $\mathrm{O}_{2}$ (balloon) for $2 \mathrm{~h}$. Then, 3-phenyl-2(phenylsulfonyl)-oxaziridine (ca. $0.5 \mathrm{M}$ solution in THF, $150 \mu \mathrm{L}, 0.075 \mathrm{mmol}$ ) was added to the mixture, and it was stirred for $4 \mathrm{~h}$, treated with $1 \mathrm{~N} \mathrm{HCl}(50 \mu \mathrm{L})$ and $\mathrm{H}_{2} \mathrm{O}(1$ $\mathrm{mL})$, and extracted with EtOAc $(3 \times 1 \mathrm{~mL})$. The combined organic layers were dried $\left(\mathrm{MgSO}_{4}\right)$ and concentrated in vacuo. Flash chromatography $\left(\mathrm{SiO}_{2}, 1.5 \times 7 \mathrm{~cm}, 10-15 \%\right.$ EtOAc in hexanes gradient elution) afforded $36(5.0 \mathrm{mg}, 0.0094 \mathrm{mmol}, 62 \%)$ as a colorless oil. 


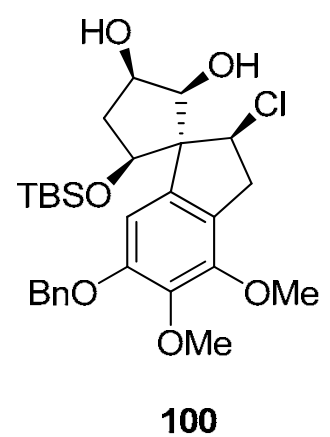

(+)-(1R,2S,2'S,3R,5S)-6'-(benzyloxy)-5-(tert-butyldimethylsilyloxy)-2'-chloro4',5'-dimethoxy-2',3'-dihydrospiro[cyclopentane-1,1'-indene]-2,3-diol (100). A solution of $96(150 \mathrm{mg}, 0.281 \mathrm{mmol})$ in anhydrous $\mathrm{THF}(2 \mathrm{~mL})$ at $0{ }^{\circ} \mathrm{C}$ under $\mathrm{Ar}$ was treated with L-Selectride (1.0 M solution in THF, $280 \mu \mathrm{L}, 0.28 \mathrm{mmol}$ ). The resultant mixture was stirred at $0{ }^{\circ} \mathrm{C}$ for $1.5 \mathrm{~h}$, then treated with sat aq $\mathrm{NH}_{4} \mathrm{Cl}(1 \mathrm{~mL})$ and warmed to rt. The mixture was extracted with EtOAc $(3 \times 3 \mathrm{~mL})$, dried $\left(\mathrm{MgSO}_{4}\right)$, and concentrated in vacuo. Flash chromatography $\left(\mathrm{SiO}_{2}, 2.5 \times 11 \mathrm{~cm}, 20 \%\right.$ EtOAc-hexanes elution) afforded $\mathbf{1 0 0}(132 \mathrm{mg}, 0.247 \mathrm{mmol}, 88 \%)$ as a pale yellow solid in 9:1 dr. A diastereomerically pure sample could be obtained after further purification: $[\alpha]^{25}{ }_{D}+22.7$ (c 1.39, $\left.\mathrm{CH}_{2} \mathrm{Cl}_{2}\right) ;{ }^{1} \mathrm{H}$ NMR $\left(\mathrm{CDCl}_{3}, 300 \mathrm{MHz}\right) \delta 7.42-7.12(\mathrm{~m}, 5 \mathrm{H}), 6.75(\mathrm{~s}, 1 \mathrm{H}), 5.07$ (s, 2H), 4.87 (dd, $J=11.1,5.7 \mathrm{~Hz}, 1 \mathrm{H}), 4.27$ (d, $J=6.6 \mathrm{~Hz}, 1 \mathrm{H}), 4.08$ (br s, 1H), 3.84 (s, 3H), $3.80(\mathrm{~s}, 3 \mathrm{H}), 3.64(\mathrm{br} \mathrm{s}, 1 \mathrm{H}), 3.56-3.38(\mathrm{~m}, 2 \mathrm{H}), 3.06(\mathrm{t}, J=12.0 \mathrm{~Hz}, 1 \mathrm{H}), 2.89$ (dd, $J$ $=12.6,7.2 \mathrm{~Hz}, 1 \mathrm{H}), 2.03-1.98(\mathrm{~m}, 1 \mathrm{H}), 1.70-1.61(\mathrm{~m}, 1 \mathrm{H}), 0.88(\mathrm{~s}, 9 \mathrm{H}), 0.21(\mathrm{~s}, 6 \mathrm{H}) ;{ }^{13} \mathrm{C}$ NMR $\left(\mathrm{CDCl}_{3}, 75 \mathrm{MHz}\right) \delta 151.6,146.4,146.3,144.3,139.1,139.0,120.8$ (2C), 120.1, 119.5 (2C), 113.6, 73.5, 71.2, 67.2, 64.0, 63.5, 63.0, 53.2, 47.4, 41.1, 37.3, 23.9, 22.0 (3C), -4.4, -4.5; IR (film) $v_{\max } 3548,2911,1626,1450,1219,1091,933 \mathrm{~cm}^{-1}$; HRMS (ESI) $\mathrm{m} / \mathrm{z} 557.20989\left(\mathrm{MNa}^{+}, \mathrm{C}_{28} \mathrm{H}_{39} \mathrm{ClO}_{6} \mathrm{SiNa}^{+}\right.$requires 557.20966). 
The cis relative stereochemistry of $\mathbf{1 0 0}$ was assigned based on the $6.6 \mathrm{~Hz}$ coupling constant of the two $\alpha$-hydroxy hydrogens. This value is similar to coupling constants reported by Hartung and Paquette ${ }^{4}$ for related cis compounds $(4.2-5.8 \mathrm{~Hz})$ and differs markedly from the value reported by Christol and $\mathrm{Vanel}^{5}$ for a related trans compound (10 Hz). Additionally, molecular models of 77 demonstrate that approach of the reducing agent to the top (re) face of the carbonyl, which would afford the trans isomer, is hindered by the neighboring chloride substituent.

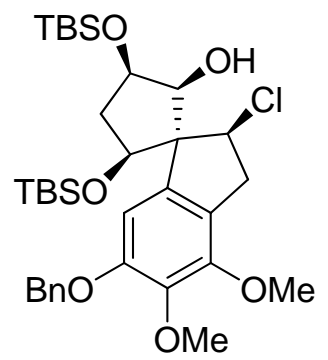

101

(+)-(1R,2S,2'S,3R,5S)-6'-(benzyloxy)-3,5-bis(tert-butyldimethylsilyloxy)-2'chloro-4',5'-dimethoxy-2',3'-dihydrospiro[cyclopentane-1,1'-inden]-2-ol (101). A solution of $100(140 \mathrm{mg}, 0.262 \mathrm{mmol})$ in anhydrous $\mathrm{CH}_{2} \mathrm{Cl}_{2}(5.0 \mathrm{~mL})$ under Ar was treated with $\mathrm{Et}_{3} \mathrm{~N}(450 \mu \mathrm{L})$, then cooled to $0^{\circ} \mathrm{C}$. TBS-Cl (59 mg, $0.39 \mathrm{mmol}, 1.5$ equiv) was added portionwise to the mixture, and it was stirred at $0^{\circ} \mathrm{C}$ for $2 \mathrm{~h}$, then at $\mathrm{rt}$ for $1 \mathrm{~h}$. The resultant mixture was diluted with EtOAc $(5 \mathrm{~mL})$, treated with sat aq $\mathrm{NH}_{4} \mathrm{Cl}(3 \mathrm{~mL})$, and the layers were separated. The aqueous layer was extracted with EtOAc $(3 \times 5 \mathrm{~mL})$,

\footnotetext{
${ }^{4}$ Hartung, R. E.; Paquette, L. A. Synthesis 2005, 3209.

${ }^{5}$ Christol, H.; Vanel, R. Bull. Soc. Chim. Fr. 1968, 1393.
} 
dried $\left(\mathrm{MgSO}_{4}\right)$, and concentrated in vacuo. Flash chromatography $\left(\mathrm{SiO}_{2}, 2.5 \times 10 \mathrm{~cm}\right.$, 7.5\% EtOAc-hexanes elution) afforded 101 (148 $\mathrm{mg}, 0.228 \mathrm{mmol}, 87 \%)$ as a light yellow oil: $[\alpha]^{25}+17\left(c 1.2, \mathrm{CH}_{2} \mathrm{Cl}_{2}\right) ;{ }^{1} \mathrm{H}$ NMR $\left(\mathrm{CDCl}_{3}, 300 \mathrm{MHz}\right) \delta 7.49-7.27(\mathrm{~m}, 5 \mathrm{H})$, 6.54 (s, 1H), 5.07 (s, 2H), 4.67 (dd, $J=12.6,7.2 \mathrm{~Hz}, 1 \mathrm{H}), 4.16(\mathrm{~d}, J=6.9 \mathrm{~Hz}, 1 \mathrm{H}), 3.86$ (s, 3H), 3.80 (s, 3H), 3.71 (br s, 1H), 3.62-3.44 (m, 2H), 3.05 (t, $J=12.0 \mathrm{~Hz}, 1 \mathrm{H}), 2.70$ (dd, $J=12.6,7.5 \mathrm{~Hz}, 1 \mathrm{H}), 2.01-1.94(\mathrm{~m}, 1 \mathrm{H}), 1.67-1.63(\mathrm{~m}, 1 \mathrm{H}), 1.17$ (s, 9H), 0.99 (s, 9H), $0.20(\mathrm{~s}, 6 \mathrm{H}), 0.14(\mathrm{~s}, 6 \mathrm{H}) ;{ }^{13} \mathrm{C} \mathrm{NMR}\left(\mathrm{CDCl}_{3}, 75 \mathrm{MHz}\right) \delta 161.2,160.4,155.1,151.8$, 145.9, 145.6, 137.6 (2C), 136.9, $136.0(2 \mathrm{C}), 133.7,79.9,79.5,75.2,72.6,72.2,70.3,53.7$, 51.8, 38.1, 34.1 (3C), 34.0 (3C), 33.2, 26.3, 17.1,-4.4 (2C), -4.5 (2C); IR (film) $v_{\max }$ $3577,2897,1610,1442,989 \mathrm{~cm}^{-1}$; HRMS (ESI) $\mathrm{m} / z 649.31418\left(\mathrm{MH}^{+}, \mathrm{C}_{34} \mathrm{H}_{53} \mathrm{ClO}_{6} \mathrm{Si}_{2} \mathrm{H}^{+}\right.$ requires 649.31420).

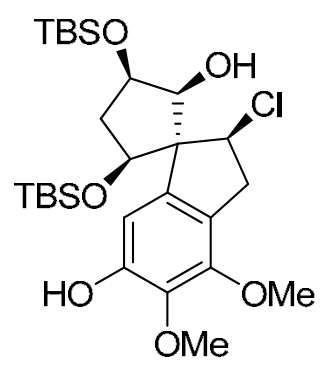

102

\section{(+)-(1R,2S,2'S,3R,5S)-3,5-bis(tert-butyldimethylsilyloxy)-2'-chloro-4',5'-} dimethoxy-2',3'-dihydrospiro[cyclopentane-1,1'-indene]-2,6'-diol (102). A solution of $101(148 \mathrm{mg}, 0.228 \mathrm{mmol})$ in anhydrous $\mathrm{MeOH}(5.0 \mathrm{~mL})$ was treated with $10 \% \mathrm{Pd} / \mathrm{C}$ (40 mg, $0.27 \mathrm{wt}$ equiv). The resultant mixture was stirred at $\mathrm{rt}$ under $\mathrm{H}_{2}(1 \mathrm{~atm})$ for $4 \mathrm{~h}$, then filtered through a plug of Celite (washed with $\left.\mathrm{CH}_{2} \mathrm{Cl}_{2}\right)$, dried $\left(\mathrm{MgSO}_{4}\right)$, and concentrated in vacuo. Flash chromatography $\left(\mathrm{SiO}_{2}, 1.5 \times 8 \mathrm{~cm}, 10 \%\right.$ EtOAc-hexanes elution) afforded $102(123 \mathrm{mg}, 0.220 \mathrm{mmol}, 96 \%)$ as a pale yellow oil: $[\alpha]^{25}+27(c$ 1.7, 
$\left.\mathrm{CHCl}_{3}\right) ;{ }^{1} \mathrm{H} \mathrm{NMR}\left(\mathrm{CDCl}_{3}, 300 \mathrm{MHz}\right) \delta 6.82(\mathrm{~s}, 1 \mathrm{H}), 4.43(\mathrm{dd}, J=12.6,7.2 \mathrm{~Hz}, 1 \mathrm{H}), 4.21$ (d, $J=6.9 \mathrm{~Hz}, 1 \mathrm{H}), 3.91$ (s, 3H), 3.88-3.84 (br s, 1H), 3.84 (s, 3H), 3.63 (br s, 1H), 3.54$3.31(\mathrm{~m}, 2 \mathrm{H}), 2.87(\mathrm{t}, J=12.0 \mathrm{~Hz}, 1 \mathrm{H}), 2.66(\mathrm{dd}, J=12.6,7.2 \mathrm{~Hz}, 1 \mathrm{H}), 2.00-1.90(\mathrm{~m}$, 1H), 1.74-1.62 (m, 1H), 1.16 (s, 9H), 1.10 (s, 9H), 0.19 (s, 6H), $0.16(\mathrm{~s}, 6 \mathrm{H}) ;{ }^{13} \mathrm{C}$ NMR $\left(\mathrm{CDCl}_{3}, 75 \mathrm{MHz}\right) \delta 148.1,142.8,139.1,133.2,128.6,128.1,82.7,75.8,75.3,69.5,69.0$, $66.5,61.1,40.8,36.7,25.8,22.1$ (6C), 13.8, $-4.4(2 \mathrm{C}),-4.5$ (2C); IR (film) $v_{\max } 3212$, 1258, 1122, $1077 \mathrm{~cm}^{-1}$; HRMS (ESI) $\mathrm{m} / 2559.26731\left(\mathrm{MH}^{+}, \mathrm{C}_{27} \mathrm{H}_{47} \mathrm{ClO}_{6} \mathrm{Si}_{2} \mathrm{H}^{+}\right.$requires $559.26725)$.

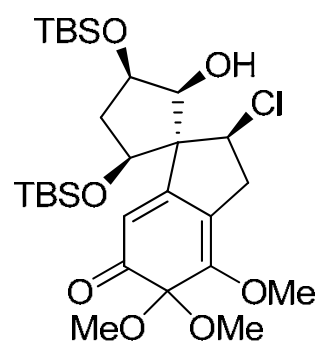

103

(-)-(1R,2S,2'S,3R,5S)-3,5-bis(tert-butyldimethylsilyloxy)-2'-chloro-2-hydroxy4',5',5'-trimethoxy-2',3'-dihydrospiro[cyclopentane-1,1'-inden]-6'(5'H)-one (103). A solution of $102(98.0 \mathrm{mg}, 0.175 \mathrm{mmol})$ in anhydrous $\mathrm{CH}_{3} \mathrm{OH}(3.0 \mathrm{~mL})$ was added to a mixture of $\mathrm{KHCO}_{3}\left(30 \mathrm{mg}, 0.35 \mathrm{mmol}, 2.0\right.$ equiv), $\mathrm{PhI}(\mathrm{OAc})_{2}(62 \mathrm{mg}, 0.19 \mathrm{mmol}, 1.1$ equiv), and anhydrous $\mathrm{CH}_{3} \mathrm{OH}(3.0 \mathrm{~mL})$ at $-10{ }^{\circ} \mathrm{C}$ under Ar. The resulting yelloworange mixture was stirred for $10 \mathrm{~min}$, diluted with $\mathrm{CH}_{2} \mathrm{Cl}_{2}(5 \mathrm{~mL})$, and washed with brine $(10 \mathrm{~mL})$. The layers were separated, and the organic layer was dried $\left(\mathrm{MgSO}_{4}\right)$ and concentrated in vacuo. Flash chromatography $\left(\mathrm{SiO}_{2}, 2.5 \times 10 \mathrm{~cm}, 10 \%\right.$ EtOAc-hexanes elution) afforded $103(69.0 \mathrm{mg}, 0.117 \mathrm{mmol}, 67 \%)$ as a yellow oil: $[\alpha]^{25}-15(c 1.2$, $\left.\mathrm{CHCl}_{3}\right) ;{ }^{1} \mathrm{H} \mathrm{NMR}\left(\mathrm{CDCl}_{3}, 300 \mathrm{MHz}\right) \delta 6.25(\mathrm{~s}, 1 \mathrm{H}), 4.55(\mathrm{dd}, J=12.6,7.5 \mathrm{~Hz}, 1 \mathrm{H}), 4.13$ 
(d, $J=6.9 \mathrm{~Hz}, 1 \mathrm{H}), 3.98(\mathrm{~s}, 3 \mathrm{H}), 3.61(\mathrm{br} \mathrm{s}, 1 \mathrm{H}), 3.49-3.24(\mathrm{~m}, 2 \mathrm{H}), 3.37$ (s, 3H), $3.32(\mathrm{~s}$, $3 \mathrm{H}), 2.79(\mathrm{t}, J=11.8 \mathrm{~Hz}, 1 \mathrm{H}), 2.58(\mathrm{dd}, J=12.6,7.5 \mathrm{~Hz}, 1 \mathrm{H}), 1.93-1.81(\mathrm{~m}, 1 \mathrm{H}), 1.58-$ $1.49(\mathrm{~m}, 1 \mathrm{H}), 0.91(\mathrm{~s}, 9 \mathrm{H}), 0.86(\mathrm{~s}, 9 \mathrm{H}), 0.10(\mathrm{~s}, 6 \mathrm{H}) 0.09(\mathrm{~s}, 6 \mathrm{H}) ;{ }^{13} \mathrm{C} \mathrm{NMR}\left(\mathrm{CDCl}_{3}, 75\right.$ MHz) $\delta 191.1,142.8,139.1,133.2,121.4,117.7,82.8,69.9,69.5,69.0,66.5,61.1,56.5$, 56.4, 40.9, 37.7, 23.8, 22.1 (6C), 13.8, -4.4 (2C), -4.6 (2C); IR (film) $v_{\max } 3337,2450$, 1755, 1233, $956 \mathrm{~cm}^{-1}$; HRMS (ESI) $\mathrm{m} / \mathrm{z} 606.30440\left(\mathrm{MNH}_{4}{ }^{+}, \mathrm{C}_{28} \mathrm{H}_{49} \mathrm{ClO}_{7} \mathrm{Si}_{2} \mathrm{NH}_{4}{ }^{+}\right.$ requires 606.30436).

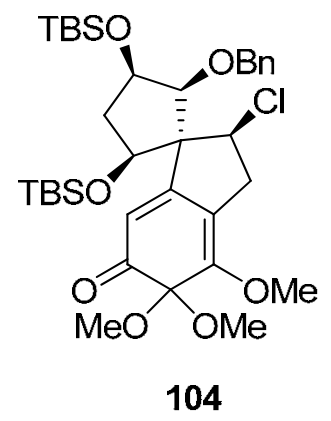

(-)-(1R,2S,2' S,3R,5S)-2-(benzyloxy)-3,5-bis(tert-butyldimethylsilyloxy)-2'chloro-4',5',5'-trimethoxy-2',3'-dihydrospiro[cyclopentane-1,1'-inden]-6'(5'H)-one (104). A solution of $103(110 \mathrm{mg}, 0.187 \mathrm{mmol})$ in anhydrous DMF $(1.5 \mathrm{~mL})$ at $\mathrm{rt}$ under Ar was treated with $\mathrm{NaH}(60 \%$ dispersion in mineral oil, $7.6 \mathrm{mg}, 4.6 \mathrm{mg} \mathrm{NaH}, 0.19$ mmol), tetrabutylammonium iodide ( $70 \mathrm{mg}, 0.190 \mathrm{mmol}$ ), and benzyl bromide ( $23 \mu \mathrm{L}$, $32.9 \mathrm{mg}, 0.192 \mathrm{mmol}$ ). The resultant brown solution was stirred at $60^{\circ} \mathrm{C}$ for $5 \mathrm{~h}$, cooled to rt, diluted with $\mathrm{CH}_{2} \mathrm{Cl}_{2}(2 \mathrm{~mL})$, and washed with brine $(2 \mathrm{~mL})$. The layers were separated, and the aqueous layer was extracted with $\mathrm{CH}_{2} \mathrm{Cl}_{2}(5 \times 3 \mathrm{~mL})$. The combined organic layers were dried $\left(\mathrm{MgSO}_{4}\right)$ and concentrated in vacuo. Flash chromatography $\left(\mathrm{SiO}_{2}, 1.5 \times 12 \mathrm{~cm}, 1 \% \mathrm{Et}_{3} \mathrm{~N}\right.$ in 5\% EtOAc-hexanes elution) afforded $104(111 \mathrm{mg}, 0.163$ mmol, 88\%) as a brown oil: $[\alpha]^{25}{ }_{\mathrm{D}}-21\left(\mathrm{c} 1.1, \mathrm{CHCl}_{3}\right) ;{ }^{1} \mathrm{H} \mathrm{NMR}\left(\mathrm{CDCl}_{3}, 300 \mathrm{MHz}\right) \delta$ 
7.42-7.18 (m, 5H), 6.39 (s, 1H), 5.20 (s, 2H), 4.99 (dd, $J=12.6,7.5 \mathrm{~Hz}, 1 \mathrm{H}), 4.76-4.72$ (m, 1H), $3.92(\mathrm{~s}, 3 \mathrm{H}), 3.63-3.46(\mathrm{~m}, 2 \mathrm{H}), 3.56(\mathrm{~s}, 3 \mathrm{H}), 3.51$, (s, 3H), $3.14(\mathrm{t}, J=11.8 \mathrm{~Hz}$ 1H), 2.77 (dd, $J=12.6,7.5 \mathrm{~Hz}, 1 \mathrm{H}), 1.83-1.71(\mathrm{~m}, 1 \mathrm{H}), 1.49-1.38(\mathrm{~m}, 1 \mathrm{H}), 0.98(\mathrm{~s}, 9 \mathrm{H})$, 0.97 (s, 9H); 0.089 (s, 6H), $0.086(\mathrm{~s}, 6 \mathrm{H}) ;{ }^{13} \mathrm{C} \mathrm{NMR}\left(\mathrm{CDCl}_{3}, 75 \mathrm{MHz}\right) \delta 192.7,150.3$, 145.1, 141.3, 135.4, 126.6 (2C), 126.0, 125.4 (2C), 123.1, 107.4, 72.1, 71.5, 71.0, 69.5, 66.0, 59.2, 59.0, 55.1, 43.4, 39.6, 27.8, 24.1 (3C), 24.0 (3C), 16.3 (2C), -4.4 (2C), -4.5 (2C); IR (film) $v_{\max } 3284,2566,1727 \mathrm{~cm}^{-1}$; HRMS (ESI) $\mathrm{m} / \mathrm{z} 679.32488\left(\mathrm{MH}^{+}\right.$, $\mathrm{C}_{35} \mathrm{H}_{55} \mathrm{ClO}_{7} \mathrm{Si}_{2} \mathrm{H}^{+}$requires 679.32476).

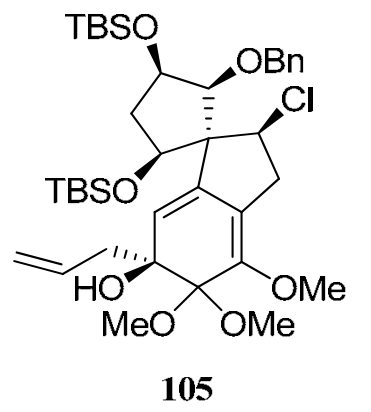

(-)-(1R,2S,2' S,3R,5S,6' S)-6'-allyl-2-(benzyloxy)-3,5-bis(tert-

\section{butyldimethylsilyloxy)-2'-chloro-4',5',5'-trimethoxy-2',3',5',6'-tetrahydrospiro}

[cyclopentane-1,1'-inden]-6'-ol (105). A solution of bis((S)-4-phenyl-4,5dihydrooxazol-2-yl)methane ${ }^{6}(76 \mathrm{mg}, 0.24 \mathrm{mmol})$ and 2,2'-dipyridyl (2 crystals), in anhydrous THF $(200 \mu \mathrm{L})$ under $\operatorname{Ar}$ at $0{ }^{\circ} \mathrm{C}$ was treated dropwise with $n$-BuLi $(1.6 \mathrm{M}$ in hexanes, $250 \mu \mathrm{L}, 0.40 \mathrm{mmol}$ ) until the mixture turned a reddish-brown color. The solution was warmed to $\mathrm{rt}$ and stirred for $1 \mathrm{~h}$, then treated dropwise with allylzinc

\footnotetext{
${ }^{6}$ Hall, J.; Lehn, J.-M.; DeCian, A.; Fischer, J. Helv. Chim. Acta 1991, 74, 1.
} 
bromide (1.0 M in THF, $240 \mu \mathrm{L}, 0.24 \mathrm{mmol})$ and cooled to $-78^{\circ} \mathrm{C}$. A solution of ketone $104(95 \mathrm{mg}, 0.14 \mathrm{mmol})$ in anhydrous THF $(220 \mu \mathrm{L})$ was added dropwise, and the resultant mixture was stirred at $\quad-78{ }^{\circ} \mathrm{C}$ under $\mathrm{Ar}$ for $1 \mathrm{~h}$. The reaction was quenched by the addition of $\mathrm{MeOH}-\mathrm{H}_{2} \mathrm{O}(1: 1,1 \mathrm{~mL})$, and the mixture was extracted with $\mathrm{Et}_{2} \mathrm{O}(3 \times 1$ $\mathrm{mL})$. The combined organic layers were washed with $\mathrm{NaOH}(0.5 \mathrm{M}, 1 \mathrm{~mL})$, dried $\left(\mathrm{MgSO}_{4}\right)$, and concentrated in vacuo. Flash chromatography $\left(\mathrm{SiO}_{2}, \quad 2: 23: 75\right.$ $\mathrm{Et}_{3} \mathrm{~N} / \mathrm{EtOAc} /$ hexanes elution) afforded $105(79 \mathrm{mg}, 0.11 \mathrm{mmol}, 93: 7 \mathrm{dr}, 79 \%)$ as a colorless oil: $[\alpha]^{25}{ }_{\mathrm{D}}-36\left(\right.$ c $\left.1.2, \mathrm{CHCl}_{3}\right) ;{ }^{1} \mathrm{H}$ NMR $\left(\mathrm{CDCl}_{3}, 300 \mathrm{MHz}\right) \delta$ 7.47-7.31 (m, 5H), 6.37-6.27 (m, 1H), $6.21(\mathrm{~s}, 1 \mathrm{H}), 5.24(\mathrm{dd}, J=12.3,7.2 \mathrm{~Hz}, 1 \mathrm{H}), 5.19(\mathrm{~s}, 2 \mathrm{H}), 4.93-$ $4.79(\mathrm{~m}, 2 \mathrm{H}), 4.65$ (d, $J=6.9 \mathrm{~Hz}, 1 \mathrm{H}), 3.82(\mathrm{~s}, 3 \mathrm{H}), 3.47-3.27$ (m, 3H), $3.41(\mathrm{~s}, 3 \mathrm{H}), 3.37$ (s, 3H), $3.09(\mathrm{t}, J=12.0 \mathrm{~Hz}, 1 \mathrm{H}), 2.74(\mathrm{dd}, J=12.3,7.2 \mathrm{~Hz}, 1 \mathrm{H}), 1.85-1.77(\mathrm{~m}, 1 \mathrm{H})$, $1.73-1.65(\mathrm{~m}, 1 \mathrm{H}), 1.57-1.53(\mathrm{~m}, 1 \mathrm{H}), 1.50-1.37(\mathrm{~m}, 1 \mathrm{H}), 0.91(\mathrm{~s}, 9 \mathrm{H}), 0.85(\mathrm{~s}, 9 \mathrm{H})$, $0.11(\mathrm{~s}, 6 \mathrm{H}), 0.08(\mathrm{~s}, 6 \mathrm{H}) ;{ }^{13} \mathrm{C} \mathrm{NMR}\left(\mathrm{CDCl}_{3}, 75 \mathrm{MHz}\right) \delta 150.3,145.1,141.3,140.9$, 135.4, 126.7 (2C), 126.1, 125.5 (2C), 123.3, 123.2, 107.4, 73.8, 72.1, 71.5, 71.0, 69.1, 65.4, 59.1, 59.0, 55.5, 48.0, 43.1, 39.6, 27.9, 24.1 (3C), 24.0 (3C), $16.4(2 \mathrm{C}),-4.4(2 \mathrm{C}),-$ 4.5 (2C); IR (film) $v_{\max } 3087,2991,2836,1629,1467,933 \mathrm{~cm}^{-1}$; HRMS (ESI) $\mathrm{m} / \mathrm{z}$ $721.37162\left(\mathrm{MH}^{+}, \mathrm{C}_{38} \mathrm{H}_{61} \mathrm{ClO}_{7} \mathrm{Si}_{2} \mathrm{H}^{+}\right.$requires 721.37171).

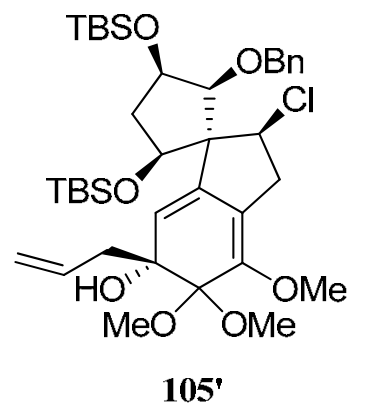




\section{(1R,2S,2'S,3R,5S,6'R)-6' -allyl-2-(benzyloxy)-3,5-bis(tert-}

\section{butyldimethylsilyloxy)-2'-chloro-4',5',5'-trimethoxy-2',3',5',6'-tetrahydrospiro}

\section{[cyclopentane-1,1'-inden]-6'-ol}

A solution of bis((R)-4-phenyl-4,5-dihydrooxazol-2-yl)methane (9.5 mg, 0.03 mmol) and 2,2'-dipyridyl ( 1 crystals), in anhydrous THF $(25 \mu \mathrm{L})$ under Ar at $0{ }^{\circ} \mathrm{C}$ was treated dropwise with $n$-BuLi (1.6 M in hexanes, $32 \mu \mathrm{L}, 0.05 \mathrm{mmol})$ until the mixture turned a reddish-brown color. The solution was warmed to rt and stirred for $1 \mathrm{~h}$, then treated dropwise with allylzinc bromide $(1.0 \mathrm{M}$ in THF, $30 \mu \mathrm{L}, 0.03 \mathrm{mmol})$ and cooled to $-78^{\circ} \mathrm{C}$. A solution of ketone $104(12 \mathrm{mg}, 0.018 \mathrm{mmol})$ in anhydrous THF $(30 \mu \mathrm{L})$ was added dropwise, and the resultant mixture was stirred at $-78{ }^{\circ} \mathrm{C}$ under Ar for $1 \mathrm{~h}$. The reaction was quenched by the addition of $\mathrm{MeOH}-\mathrm{H}_{2} \mathrm{O}(1: 1,0.5 \mathrm{~mL})$, and the mixture was extracted with $\mathrm{Et}_{2} \mathrm{O}(3 \times 0.5 \mathrm{~mL})$. The combined organic layers were washed with $\mathrm{NaOH}$ (0.5 M, $0.5 \mathrm{~mL})$, dried $\left(\mathrm{MgSO}_{4}\right)$, and concentrated in vacuo. Flash chromatography $\left(\mathrm{SiO}_{2}, 2: 23: 75 \mathrm{Et}_{3} \mathrm{~N} / \mathrm{EtOAc} /\right.$ hexanes elution) afforded 105’ (8.9 mg, $0.012 \mathrm{mmol}, 13: 87$ $\mathrm{dr}, 69 \%)$ as a colorless oil: $[\alpha]^{25} 12.4\left(c \mathrm{c} 0.88, \mathrm{CHCl}_{3}\right) ;{ }^{1} \mathrm{H} \mathrm{NMR}\left(\mathrm{CDCl}_{3}, 300 \mathrm{MHz}\right) \delta$ 7.48-7.34 (m, 5H), 6.50-6.40 (m, 1H), $6.21(\mathrm{~s}, 1 \mathrm{H}), 5.26(\mathrm{dd}, J=12.3,7.2 \mathrm{~Hz}, 1 \mathrm{H}), 5.22$ (s, 2H), 5.00-4.87 (m, 2H), $4.66(\mathrm{~d}, J=6.9 \mathrm{~Hz}, 1 \mathrm{H}), 3.83(\mathrm{~s}, 3 \mathrm{H}), 3.51-3.30(\mathrm{~m}, 3 \mathrm{H})$, $3.44(\mathrm{~s}, 3 \mathrm{H}), 3.40(\mathrm{~s}, 3 \mathrm{H}), 3.12(\mathrm{t}, J=12.0 \mathrm{~Hz}, 1 \mathrm{H}), 2.76(\mathrm{dd}, J=12.3,7.2 \mathrm{~Hz}, 1 \mathrm{H}), 1.95-$ $1.88(\mathrm{~m}, 1 \mathrm{H}), 1.75-1.68(\mathrm{~m}, 1 \mathrm{H}), 1.60-1.58(\mathrm{~m}, 1 \mathrm{H}), 1.53-1.40(\mathrm{~m}, 1 \mathrm{H}), 0.94(\mathrm{~s}, 9 \mathrm{H})$, 0.88 (s, 9H), 0.14 (s, 6H), 0.11 (s, 6H); IR (film) $v_{\max } 3054,2980,1655,1521,1458,917$, $632 \mathrm{~cm}^{-1}$; HRMS (ESI) m/z $721.37180\left(\mathrm{MH}^{+}, \mathrm{C}_{38} \mathrm{H}_{61} \mathrm{ClO}_{7} \mathrm{Si}_{2} \mathrm{H}^{+}\right.$requires 721.37171). 


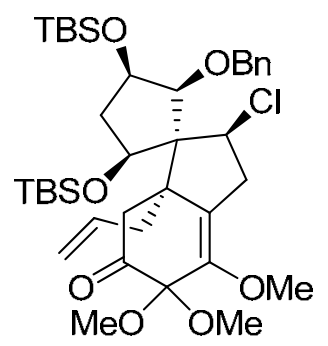

106

\section{(-)-(1R,2S,2'S,3R,5S,7a'R)-7a'-allyl-2-(benzyloxy)-3,5-bis(tert-}

\section{butyldimethylsilyloxy)-2'-chloro-4',5',5'-trimethoxy-2',3',7',7a'-tetrahydrospiro}

[cyclopentane-1,1'-inden]-6'(5'H)-one (106). A mixture of 18-crown-6 (34 mg, 0.13 mmol), $\mathrm{KOt}$-Bu $(14 \mathrm{mg}, 0.13 \mathrm{mmol})$, and anhydrous $\mathrm{THF}(700 \mu \mathrm{l})$ at $0{ }^{\circ} \mathrm{C}$ under $\mathrm{Ar}$ was stirred for $15 \mathrm{~min}$, then treated with a solution of $105(30.0 \mathrm{mg}, 0.0416 \mathrm{mmol})$ in anhydrous THF (150 $\mu \mathrm{L}$, added dropwise over $3 \mathrm{~min})$. The resulting mixture was stirred at $0{ }^{\circ} \mathrm{C}$ under $\mathrm{Ar}$ for $1 \mathrm{~h}$. The reaction was quenched by the addition of $\mathrm{H}_{2} \mathrm{O}(1 \mathrm{~mL})$, and the mixture was diluted with $\mathrm{Et}_{2} \mathrm{O}(2 \mathrm{~mL})$. The layers were separated, and the organic layer was dried $\left(\mathrm{MgSO}_{4}\right)$ and concentrated in vacuo. Flash chromatography $\left(\mathrm{SiO}_{2}, 1 \%\right.$ $\mathrm{Et}_{3} \mathrm{~N}$ in $10 \%$ EtOAc-hexanes elution) afforded $106(27.5 \mathrm{mg}, 0.0381 \mathrm{mmol}, 92 \%)$ as a colorless oil: $[\alpha]^{25}{ }_{\mathrm{D}}-22\left(\mathrm{c} 1.5, \mathrm{CHCl}_{3}\right) ;{ }^{1} \mathrm{H} \mathrm{NMR}\left(\mathrm{CDCl}_{3}, 300 \mathrm{MHz}\right) \delta 7.52-7.34(\mathrm{~m}$, 5H), 5.88-5.76 (m, 1H), $5.27(\mathrm{dd}, J=12.2,7.0 \mathrm{~Hz}, 1 \mathrm{H}), 5.20(\mathrm{~s}, 2 \mathrm{H}), 5.00-4.88(\mathrm{~m}, 2 \mathrm{H})$, $4.60(\mathrm{~d}, J=6.9 \mathrm{~Hz}, 1 \mathrm{H}), 3.91(\mathrm{~s}, 3 \mathrm{H}), 3.58-3.42(\mathrm{~m}, 2 \mathrm{H}), 3.50(\mathrm{~s}, 3 \mathrm{H}), 3.45(\mathrm{~s}, 3 \mathrm{H}), 3.10$ $(\mathrm{t}, J=11.8 \mathrm{~Hz}, 1 \mathrm{H}), 2.98(\mathrm{~d}, J=14.7 \mathrm{~Hz}, 1 \mathrm{H}), 2.72(\mathrm{dd}, J=12.2,7.0 \mathrm{~Hz}, 1 \mathrm{H}), 2.56(\mathrm{~d}, J$ $=15.0 \mathrm{~Hz}, 1 \mathrm{H}), 1.89-1.81(\mathrm{~m}, 1 \mathrm{H}), 1.78-1.69(\mathrm{~m}, 1 \mathrm{H}), 1.67-1.62(\mathrm{~m}, 1 \mathrm{H}), 1.58-1.51(\mathrm{~m}$, 1H). $0.97(\mathrm{~s}, 9 \mathrm{H}), 0.94(\mathrm{~s}, 9 \mathrm{H}), 0.10(\mathrm{~s}, 6 \mathrm{H}), 0.08(\mathrm{~s}, 6 \mathrm{H}) ;{ }^{13} \mathrm{C} \mathrm{NMR}\left(\mathrm{CDCl}_{3}, 75 \mathrm{MHz}\right) \delta$ $192.5,147.7,142.5,138.8,132.8,124.2(2 \mathrm{C}), 123.5,122.9$ (2C), 120.7, 104.8, 71.1, 69.6, 
68.9, 68.4, 66.6, 56.6, 56.4, 52.9, 49.8, 41.2, 40.5, 37.0, 36.3, 25.3, 21.5 (3C), $21.4(3 \mathrm{C})$,

13.9 (2C), -5.0 (2C), -5.1 (2C); IR (film) $v_{\max } 3055,2978,2844,1782,1631,1423,1012$, $941 \mathrm{~cm}^{-1}$; HRMS (ESI) m/z $721.37180\left(\mathrm{MH}^{+}, \mathrm{C}_{38} \mathrm{H}_{61} \mathrm{ClO}_{7} \mathrm{Si}_{2} \mathrm{H}^{+}\right.$requires 721.37171$)$.

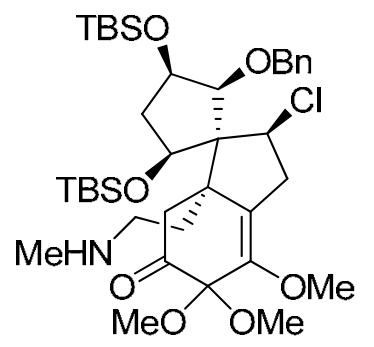

107

(-)-(1R,2S,2'S,3R,5S,7a'R)-2-(benzyloxy)-3,5-bis(tert-butyldimethylsilyloxy)2'-chloro-4',5',5'-trimethoxy-7a'-(2-(methylamino)ethyl)-2',3',7',7a'-tetrahydrospiro [cyclopentane-1,1'-inden]-6'(5'H)-one (107). A saturated solution of $\mathrm{O}_{3}$ in EtOAc was prepared by bubbling ozone through EtOAc at $-78{ }^{\circ} \mathrm{C}$ for $10 \mathrm{~min}$. The concentration was determined to be $0.007 \mathrm{M}$ as measured by titration with styrene. ${ }^{7}$ Then, a solution of $\mathbf{1 0 6}$ (27 mg, $0.037 \mathrm{mmol})$, pyridine $(10 \mu \mathrm{L})$, and $\mathrm{Et}_{3} \mathrm{~N}(16.0 \mu \mathrm{L}, 11.6 \mathrm{mg}, 0.115 \mathrm{mmol}, 3.1$ equiv) in EtOAc $(0.5 \mathrm{~mL})$ was cooled to $-40^{\circ} \mathrm{C}$. A portion of the previously prepared solution of $\mathrm{O}_{3}$ in EtOAc $(0.007 \mathrm{M}, 8 \mathrm{~mL}, 0.056 \mathrm{mmol}, 1.5$ equiv), which was precooled to $-78^{\circ} \mathrm{C}$, was then added to this solution. The resultant mixture was stirred at $-78{ }^{\circ} \mathrm{C}$ for $5 \mathrm{~min}$, then diluted with anhydrous $\mathrm{MeOH}(1.0 \mathrm{~mL})$ and treated with powdered $4 \AA$ molecular sieves $(30 \mathrm{mg})$ and $\mathrm{CH}_{3} \mathrm{NH}_{2}(2.0 \mathrm{M}$ in $\mathrm{MeOH}, 76 \mu \mathrm{L}, 0.15 \mathrm{mmol}, 4.1$ equiv). This mixture was stirred at $\mathrm{rt}$ under Ar for $30 \mathrm{~min}$, then treated with $\mathrm{NaBH}_{3} \mathrm{CN}$ (4.8 mg, 
$0.076 \mathrm{mmol})$ and stirred for $16 \mathrm{~h}$. It was then diluted with EtOAc $(2 \mathrm{~mL})$, washed with aq $\mathrm{KOH}(10 \mathrm{M}, 1 \mathrm{~mL})$, and the layers were separated. The aqueous layer was extracted with EtOAc $(3 \times 2 \mathrm{~mL})$, and the combined organic layers were dried $\left(\mathrm{MgSO}_{4}\right)$ and concentrated in vacuo. Flash chromatography $\left(\mathrm{SiO}_{2}, 1 \% \mathrm{Et}_{3} \mathrm{~N}\right.$ in $15-20 \% \mathrm{EtOAc}-$ hexanes gradient elution) afforded recovered 106 (7.3 $\mathrm{mg}, 27 \%$ recovery) and 107 (15 mg, $0.020 \mathrm{mmol}, 54 \%, 74 \%$ based on recovered 106) as a yellow oil: $[\alpha]^{25}-25(c 1.4$, $\left.\mathrm{CHCl}_{3}\right) ;{ }^{1} \mathrm{H}$ NMR $\left(\mathrm{CDCl}_{3}, 300 \mathrm{MHz}\right) \delta 7.52-7.32(\mathrm{~m}, 5 \mathrm{H}), 5.05(\mathrm{~s}, 2 \mathrm{H}), 4.83(\mathrm{dd}, J=$ 12.0, $6.9 \mathrm{~Hz}, 1 \mathrm{H}), 4.61(\mathrm{~d}, J=6.9 \mathrm{~Hz}, 1 \mathrm{H}), 4.02(\mathrm{~s}, 3 \mathrm{H}), 3.87-3.73(\mathrm{~m}, 2 \mathrm{H}), 3.62(\mathrm{~s}, 3 \mathrm{H})$, $3.57(\mathrm{~s}, 3 \mathrm{H}), 3.06(\mathrm{t}, J=11.8 \mathrm{~Hz}, 1 \mathrm{H}), 2.97(\mathrm{~s}, 3 \mathrm{H}), 2.71-2.62(\mathrm{~m}, 2 \mathrm{H}), 2.38(\mathrm{dd}, J=12.2$, $7.0 \mathrm{~Hz}, 1 \mathrm{H}), 2.28(\mathrm{~d}, J=15.0 \mathrm{~Hz}, 1 \mathrm{H}), 2.23(\mathrm{br} \mathrm{s}, 1 \mathrm{H}), 2.18-2.13(\mathrm{~m}, 1 \mathrm{H}), 2.00(\mathrm{~d}, J=$ $15.0 \mathrm{~Hz}, 1 \mathrm{H}), 1.69-1.61(\mathrm{~m}, 1 \mathrm{H}), 1.44-1.38(\mathrm{~m}, 1 \mathrm{H}), 1.35-1.28(\mathrm{~m}, 1 \mathrm{H}), 0.87(\mathrm{~s}, 9 \mathrm{H})$, $0.81(\mathrm{~s}, 9 \mathrm{H}), 0.10(\mathrm{~s}, 6 \mathrm{H}), 0.07(\mathrm{~s}, 6 \mathrm{H}) ;{ }^{13} \mathrm{C} \mathrm{NMR}\left(\mathrm{CDCl}_{3}, 125 \mathrm{MHz}\right) \delta 197.1,152.4$, 147.1, 137.4, 128.8 (2C), 128.1, 127.5 (2C), 109.4, 75.1, 74.1, 73.6, 73.0, 71.2, 61.2, 61.0, $54.1,50.0,47.0,45.9,45.1,41.7,40.9,39.2,29.9,26.1$ (3C), $26.0(3 \mathrm{C}), 18.2(2 \mathrm{C}),-4.5$ (2C), -5.0 (2C); IR (film) $v_{\max } 3125,2923,2810,1741,1633,1420,1208,1138,982 \mathrm{~cm}^{-}$ 1; HRMS (ESI) m/z 760.38014 $\left(\mathrm{MNa}^{+}, \mathrm{C}_{38} \mathrm{H}_{64} \mathrm{ClNO}_{7} \mathrm{Si}_{2} \mathrm{Na}^{+}\right.$requires 760.38021).

\footnotetext{
${ }^{7}$ Wender, P. A.; DeChristopher, B. A.; Schrier, A. J. J. Am. Chem. Soc. 2008, 130, 6658.
} 


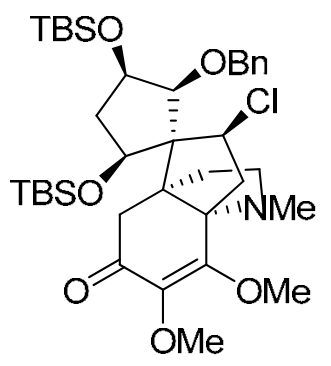

111

Tetracycle (-)-111. A mixture of 107 (15 mg, $0.020 \mathrm{mmol}), 4 \AA \mathrm{MS}(80 \mathrm{mg})$, and anhydrous $\mathrm{CH}_{2} \mathrm{Cl}_{2}(2.0 \mathrm{~mL})$ was stirred at $\mathrm{rt}$ under Ar for $10 \mathrm{~min}$, then cooled to -40

- C. Next, $\mathrm{BCl}_{3}\left(1.0 \mathrm{M}\right.$ in $\mathrm{CH}_{2} \mathrm{Cl}_{2}, 30 \mu \mathrm{L}, 0.030 \mathrm{mmol}, 1.5$ equiv) was added dropwise, and the resultant mixture was stirred at $-40{ }^{\circ} \mathrm{C}$ under Ar for $18 \mathrm{~h}$, then concentrated in vacuo. The residue was purified by flash chromatography $\left(\mathrm{SiO}_{2}, 2: 30: 68\right.$ $\mathrm{Et}_{3} \mathrm{~N} / \mathrm{EtOAc} /$ hexanes elution), affording 111 (6.4 $\left.\mathrm{mg}, 0.0091 \mathrm{mmol}, 45 \%\right)$ as a colorless oil: $[\alpha]_{\mathrm{D}}^{25}-79\left(c\right.$ 1.2, $\left.\mathrm{CHCl}_{3}\right) ;{ }^{1} \mathrm{H}$ NMR (pyridine- $\left.d_{5}, 500 \mathrm{MHz}\right) \delta 7.44-7.41(\mathrm{~m}, 3 \mathrm{H})$, 7.36-7.33 (m, 2H), $5.25(\mathrm{dd}, J=12.2,6.8 \mathrm{~Hz}, 1 \mathrm{H}), 5.12(\mathrm{~s}, 2 \mathrm{H}), 4.80(\mathrm{~d}, J=7.0 \mathrm{~Hz}, 1 \mathrm{H})$, $4.14(\mathrm{~s}, 3 \mathrm{H}), 3.84(\mathrm{~s}, 3 \mathrm{H}), 3.50-3.44(\mathrm{~m}, 1 \mathrm{H}), 3.41-3.36(\mathrm{~m}, 1 \mathrm{H}), 3.20(\mathrm{t}, J=12.0 \mathrm{~Hz}$ 1H), $3.11(\mathrm{~d}, J=15.5 \mathrm{~Hz}, 1 \mathrm{H}), 2.75-2.69(\mathrm{~m}, 3 \mathrm{H}), 2.61(\mathrm{~d}, J=15.5 \mathrm{~Hz}, 1 \mathrm{H}), 2.52-2.47$ $(\mathrm{m}, 1 \mathrm{H}), 2.46(\mathrm{~s}, 3 \mathrm{H}), 1.71-1.68(\mathrm{~m}, 1 \mathrm{H}), 1.55-1.50(\mathrm{~m}, 1 \mathrm{H}), 1.46-1.40(\mathrm{~m}, 1 \mathrm{H}), 0.96(\mathrm{~s}$ 9H), $0.92(\mathrm{~s}, 9 \mathrm{H}), 0.26(\mathrm{~s}, 3 \mathrm{H}), 0.22(\mathrm{~s}, 3 \mathrm{H}), 0.13(\mathrm{~s}, 6 \mathrm{H}) ;{ }^{13} \mathrm{C}$ NMR (pyridine- $d_{5}, 125$ MHz) $\delta 192.0,158.8,142.3,138.1,129.9$ (2C), 129.2, 128.4 (2C), 76.2, 75.8, 75.3, 74.2, $72.0,67.4,59.5,59.2,56.9,52.3,50.8,46.3,44.0,40.5,37.6,35.4,30.0(3 \mathrm{C}), 29.8(3 \mathrm{C})$, 20.0 (2C), -4.1 (2C), -4.2 (2C); IR (film) $v_{\max } 3209,2974,2795,1763,1651,1402$, 1265, $912 \mathrm{~cm}^{-1}$; HRMS (ESI) $\mathrm{m} / \mathrm{z} 706.37199\left(\mathrm{MH}^{+}, \mathrm{C}_{37} \mathrm{H}_{60} \mathrm{ClNO}_{6} \mathrm{Si}_{2} \mathrm{H}^{+}\right.$requires 706.37205). 


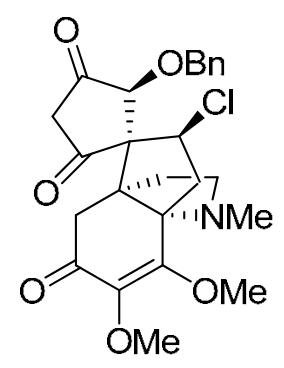

112

1,3-diketone (-)-115. A solution of $111(8.7 \mathrm{mg}, 0.012 \mathrm{mmol})$ in anhydrous THF $(100 \mu \mathrm{L})$ at $0^{\circ} \mathrm{C}$ under Ar was treated with TBAF $(1.0 \mathrm{M}$ in THF, $27 \mu \mathrm{L}, 0.027 \mathrm{mmol}$, 2.2 equiv) in one portion. The resulting mixture was stirred at $0^{\circ} \mathrm{C}$ for $20 \mathrm{~min}$. The reaction was quenched by the addition of ice water $(0.5 \mathrm{~mL})$, and the mixture was extracted with cold $\mathrm{CH}_{2} \mathrm{Cl}_{2}$ (cooled in ice bath, $3 \times 0.5 \mathrm{~mL}$ ). The combined organic layers were dried $\left(\mathrm{MgSO}_{4}\right)$ and concentrated in vacuo in an ice bath. The unstable crude diol was dissolved in acetone $(0.5 \mathrm{~mL})$ at $0{ }^{\circ} \mathrm{C}$, then $4 \AA \mathrm{MS}(50 \mathrm{mg})$, NMO $(4.2 \mathrm{mg}$, $0.036 \mathrm{mmol})$, and TPAP $(0.4 \mathrm{mg}, 0.001 \mathrm{mmol})$ were added in order to the solution. The resulting mixture was stirred at $0^{\circ} \mathrm{C}$ under Ar for $30 \mathrm{~min}$, then slowly warmed to rt over $1 \mathrm{~h}$ and stirred at $\mathrm{rt}$ for 1 additional $\mathrm{h}$. It was then filtered through a plug of $\mathrm{SiO}_{2}$ (rinsed with $5 \mathrm{~mL}$ EtOAc), dried $\left(\mathrm{MgSO}_{4}\right)$, and concentrated in vacuo. Flash chromatography $\left(\mathrm{SiO}_{2}, 1 \% \mathrm{Et}_{3} \mathrm{~N}\right.$ in $2 \% \mathrm{MeOH}-\mathrm{CH}_{2} \mathrm{Cl}_{2}$ elution) afforded $112(3.3 \mathrm{mg}, 0.0070 \mathrm{mmol}, 57 \%)$ as a white solid: $[\alpha]^{25}-122\left(c 0.7, \mathrm{CH}_{2} \mathrm{Cl}_{2}\right) ;{ }^{1} \mathrm{H}$ NMR (pyridine- $\left.d_{5}, 500 \mathrm{MHz}\right) \delta 7.46-$ $7.42(\mathrm{~m}, 3 \mathrm{H}), 7.39-7.37(\mathrm{~m}, 2 \mathrm{H}), 5.20(\mathrm{dd}, J=12.0,6.5 \mathrm{~Hz}, 1 \mathrm{H}), 5.02(\mathrm{~s}, 2 \mathrm{H}), 4.87(\mathrm{~s}$, 1H), $4.10(\mathrm{~s}, 3 \mathrm{H}), 3.92(\mathrm{~d}, J=14.0 \mathrm{~Hz}, 1 \mathrm{H}), 3.80$ (s, 3H), $3.74(\mathrm{~d}, J=14.0 \mathrm{~Hz}, 1 \mathrm{H}), 3.16$ $(\mathrm{t}, J=12.5 \mathrm{~Hz}, 1 \mathrm{H}), 3.07(\mathrm{~d}, J=16.0 \mathrm{~Hz}, 1 \mathrm{H}), 2.70-2.63(\mathrm{~m}, 3 \mathrm{H}), 2.55(\mathrm{~d}, J=15.5 \mathrm{~Hz}$, 1H), 2.45-2.41 (m, 1H), $2.40(\mathrm{~s}, 3 \mathrm{H}), 1.65-1.62(\mathrm{~m}, 1 \mathrm{H}) ;{ }^{13} \mathrm{C}$ NMR (pyridine- $d_{5}, 125$ 
MHz) $\delta$ 202.8, 201.4, 193.3, 160.2, 143.6, 139.4, 131.6 (2C), 130.9, 130.3 (2C), 73.4, $71.9,71.2,69.1,60.9,60.6,59.3,58.3,52.1,47.7,46.9,41.9,39.0,36.8$; IR (film) $v_{\max }$ 3024, 2931, 2795, 1825, 1633, 1429, 1176, $955 \mathrm{~cm}^{-1}$; HRMS (ESI) m/z $474.16785\left(\mathrm{MH}^{+}\right.$, $\mathrm{C}_{25} \mathrm{H}_{28} \mathrm{ClNO}_{6} \mathrm{H}^{+}$requires 474.16779).

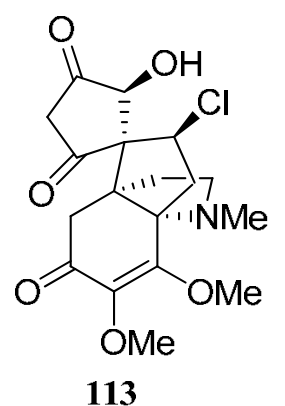

Alcohol (-)-113. To a solution of $112(3.0 \mathrm{mg}, 0.0063 \mathrm{mmol})$ in anhydrous $\mathrm{MeOH}(1.0 \mathrm{~mL})$ under Ar was added 10\% $\mathrm{Pd} / \mathrm{C}(10 \mathrm{mg}, 3.3 \mathrm{wt}$ equiv). The resulting mixture was stirred at $\mathrm{rt}$ under $\mathrm{H}_{2}(1 \mathrm{~atm})$ for $2 \mathrm{~h}$, then filtered through a plug of Celite (washed with $\left.\mathrm{CH}_{2} \mathrm{Cl}_{2}\right)$, dried $\left(\mathrm{MgSO}_{4}\right)$, and concentrated in vacuo. Flash chromatography $\left(\mathrm{SiO}_{2}, 1.5 \times 8 \mathrm{~cm}, 5 \% \mathrm{MeOH}-\mathrm{CH}_{2} \mathrm{Cl}_{2}\right.$ elution) afforded $113(2.4 \mathrm{mg}$, 0.0063 mmol, $99 \%)$ as a pale yellow oil: $[\alpha]^{25}-135\left(c \quad 0.6, \mathrm{CH}_{2} \mathrm{Cl}_{2}\right) ;{ }^{1} \mathrm{H}$ NMR (pyridine- $\left.d_{5}, 500 \mathrm{MHz}\right) \delta 8.66(\mathrm{br} \mathrm{s}, 1 \mathrm{H}), 5.30(\mathrm{dd}, J=12.0,6.5 \mathrm{~Hz}, 1 \mathrm{H}), 5.13(\mathrm{~s}, 1 \mathrm{H})$, 4.14 (s, 3H), 4.03 (d, $J=14.0 \mathrm{~Hz}, 1 \mathrm{H}), 3.83$ (s, 3H), 3.76 (d, $J=14.0 \mathrm{~Hz}, 1 \mathrm{H}), 3.26$ (t, $J$ $=12.2 \mathrm{~Hz}, 1 \mathrm{H}), 3.17(\mathrm{~d}, J=15.5 \mathrm{~Hz}, 1 \mathrm{H}), 2.82-2.74(\mathrm{~m}, 3 \mathrm{H}), 2.65(\mathrm{~d}, J=15.5 \mathrm{~Hz}, 1 \mathrm{H})$, $2.55-2.52(\mathrm{~m}, 1 \mathrm{H}), 2.50(\mathrm{~s}, 3 \mathrm{H}), 1.76-1.73(\mathrm{~m}, 1 \mathrm{H}) ;{ }^{13} \mathrm{C}$ NMR (pyridine- $\left.d_{5}, 125 \mathrm{MHz}\right) \delta$ 203.1. 201.7, 194.1, 160.9, 140.2, 72.9, 71.7, 69.3, 60.2, 59.9, 56.8, 55.5, 53.2, 48.9, 46.1, 42.0, 38.4, 36.4; IR (film) $v_{\max } 3054,2832,1836,1477,1201,934 \mathrm{~cm}^{-1}$; HRMS (ESI) $\mathrm{m} / \mathrm{z} 406.10270\left(\mathrm{MNa}^{+}, \mathrm{C}_{18} \mathrm{H}_{22} \mathrm{ClNO}_{6} \mathrm{Na}^{+}\right.$requires 406.10279). 


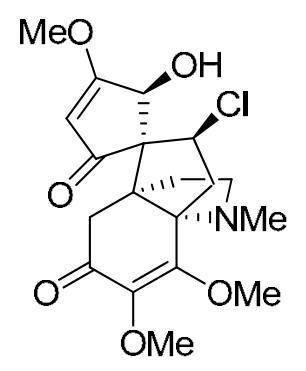

1

(-)-Acutumine (1). $\mathrm{TiCl}_{4}\left(0.04 \mathrm{M}\right.$ solution in $\left.\mathrm{CH}_{2} \mathrm{Cl}_{2}, 20 \mu \mathrm{L}, 0.0008 \mathrm{mmol}\right)$ was added to a solution of $113(2.0 \mathrm{mg}, 0.0052 \mathrm{mmol})$ in anhydrous $\mathrm{MeOH}(100 \mu \mathrm{L})$. The solution was stirred at $\mathrm{rt}$ for $15 \mathrm{~min}$, then treated with $\mathrm{Et}_{3} \mathrm{~N}(4 \mu \mathrm{L}, 2.9 \mathrm{mg}, 0.029 \mathrm{mmol})$ and stirred at $\mathrm{rt}$ for $45 \mathrm{~min}$. The mixture was concentrated in vacuo, and the residue was purified by flash chromatography $\left(\mathrm{SiO}_{2}, 1.5 \times 6 \mathrm{~cm}, 1 \% \mathrm{Et}_{3} \mathrm{~N}\right.$ in $5-15 \% \mathrm{MeOH}-\mathrm{CH}_{2} \mathrm{Cl}_{2}$ gradient elution), affording $1(1.1 \mathrm{mg}, 0.0027 \mathrm{mmol}, 52 \%)$ and enol ether regioisomer $114(0.3 \mathrm{mg}, 0.00075 \mathrm{mmol}, 14 \%)$. For 1: white film, $[\alpha]_{\mathrm{D}}^{25}-171$ (c 0.81 , pyridine), lit $^{8}$ $[\alpha]^{25} \mathrm{D}-206$ (c 0.69, pyridine); ${ }^{1} \mathrm{H}$ NMR (pyridine- $\left.d_{5}, 500 \mathrm{MHz}\right) \delta 8.47(\mathrm{br}, \mathrm{s}, 1 \mathrm{H}), 5.61$ (s, 1H), $5.20(\mathrm{dd}, J=11.8,6.8 \mathrm{~Hz}, 1 \mathrm{H}), 5.03\left(\mathrm{~s}, 1 \mathrm{H}\right.$, obscured by $\left.\mathrm{H}_{2} \mathrm{O}\right), 4.04(\mathrm{~s}, 3 \mathrm{H}), 3.80$ (s, 3H), $3.73(\mathrm{~s}, 3 \mathrm{H}), 3.16(\mathrm{t}, J=12.0 \mathrm{~Hz}, 1 \mathrm{H}), 3.07$ (d, $J=15.5 \mathrm{~Hz}, 1 \mathrm{H}), 2.69-2.63$ (m, $3 \mathrm{H}), 2.54(\mathrm{~d}, J=15.5 \mathrm{~Hz}, 1 \mathrm{H}), 2.45-2.42(\mathrm{~m}, 1 \mathrm{H}), 2.39(\mathrm{~s}, 3 \mathrm{H}), 1.65-1.62(\mathrm{~m}, 1 \mathrm{H}) ;{ }^{13} \mathrm{C}$ NMR (pyridine- $\left.d_{5}, 125 \mathrm{MHz}\right) \delta 201.3,192.8,188.9,159.7,138.9,105.5,72.9,70.7,68.3$, $60.4,60.1,58.8,57.8,53.2,51.6,47.2,41.4,38.5,36.3$; IR (film) $v_{\max } 3410,2899,2817$,

\footnotetext{
${ }^{8}$ Tomita, M.; Okamoto, Y.; Kikuchi, T.; Osaki, K.; Nishikawa, M.; Kamiya, K.; Sasaki, Y.; Matoba, K.; Goto, K. Tetrahedron Lett. 1967, 2421.
} 
1655, 1641, 1364, 1205, 1079, $935 \mathrm{~cm}^{-1}$; HRMS (ESI) $\mathrm{m} / \mathrm{z} 398.13655\left(\mathrm{MH}^{+}\right.$, $\mathrm{C}_{19} \mathrm{H}_{24} \mathrm{ClNO}_{6} \mathrm{H}^{+}$requires 398.13649).

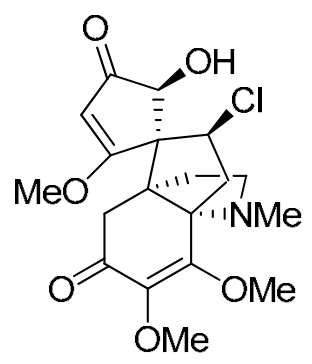

114

For 114: white film, $[\alpha]^{25}-112$ (c 0.3, pyridine), ${ }^{1} \mathrm{H}$ NMR (pyridine- $d_{5}, 500$ MHz) $\delta 8.40(\mathrm{br}, \mathrm{s}, 1 \mathrm{H}), 5.32(\mathrm{~s}, 1 \mathrm{H}), 5.16(\mathrm{dd}, J=12.0,7.0 \mathrm{~Hz}, 1 \mathrm{H}), 4.94(\mathrm{~s}, 1 \mathrm{H}), 4.07$ (s, 3H), 3.74 (s, 3H), 3.57 (s, 3H), $3.13(\mathrm{t}, J=12.5 \mathrm{~Hz}, 1 \mathrm{H}), 3.02$ (d, $J=16.5 \mathrm{~Hz}, 1 \mathrm{H})$, 2.67-2.60 (m, 3H), 2.48 (d, $J=15.5 \mathrm{~Hz}, 1 \mathrm{H}), 2.43-2.38$ (m, 1H), 2.36 (s, 3H), 1.62-1.60 (m, 1H); HRMS (ESI) m/z $398.13664\left(\mathrm{MH}^{+}, \mathrm{C}_{19} \mathrm{H}_{24} \mathrm{ClNO}_{6} \mathrm{H}^{+}\right.$requires 398.13649). 
ㄱ.

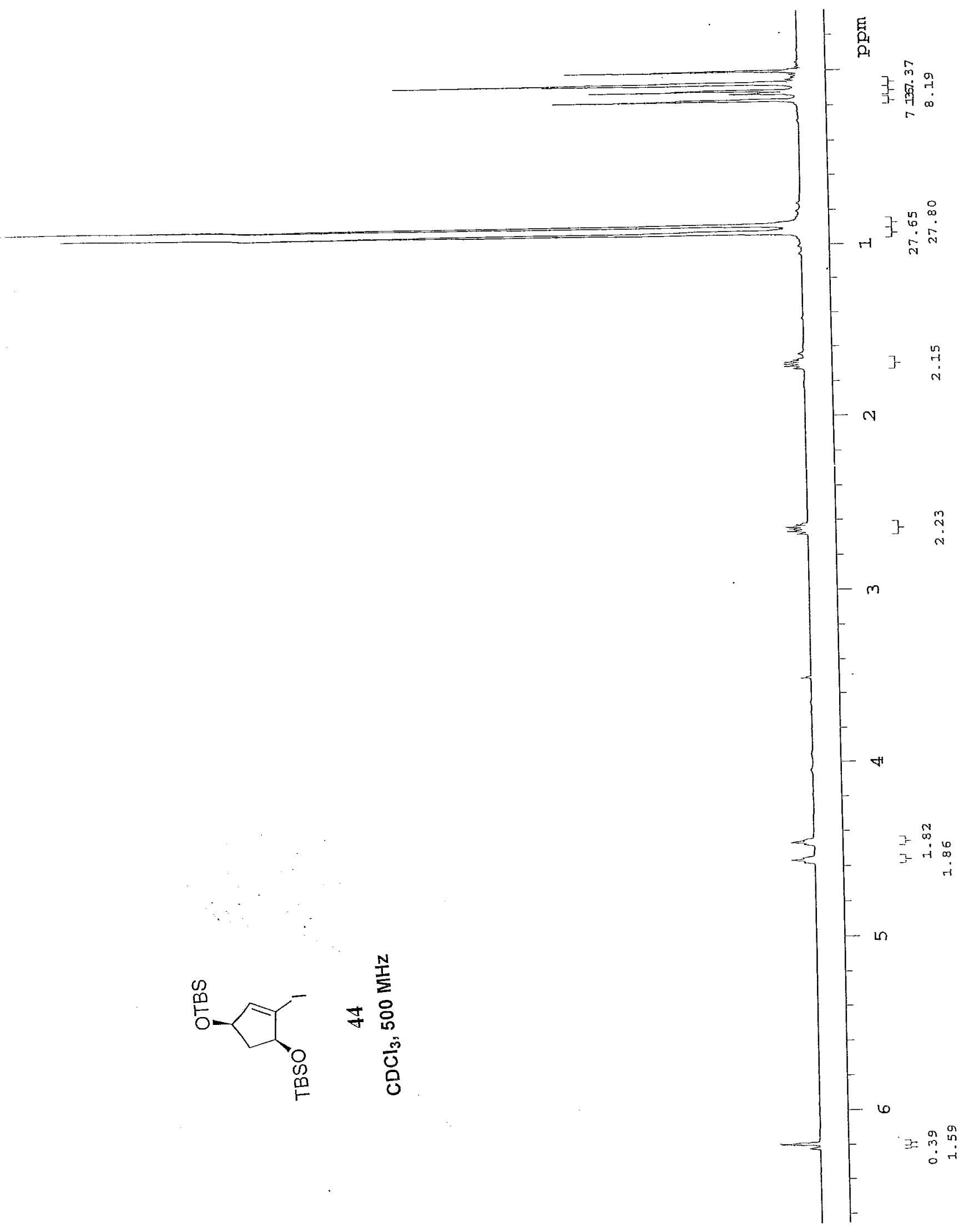




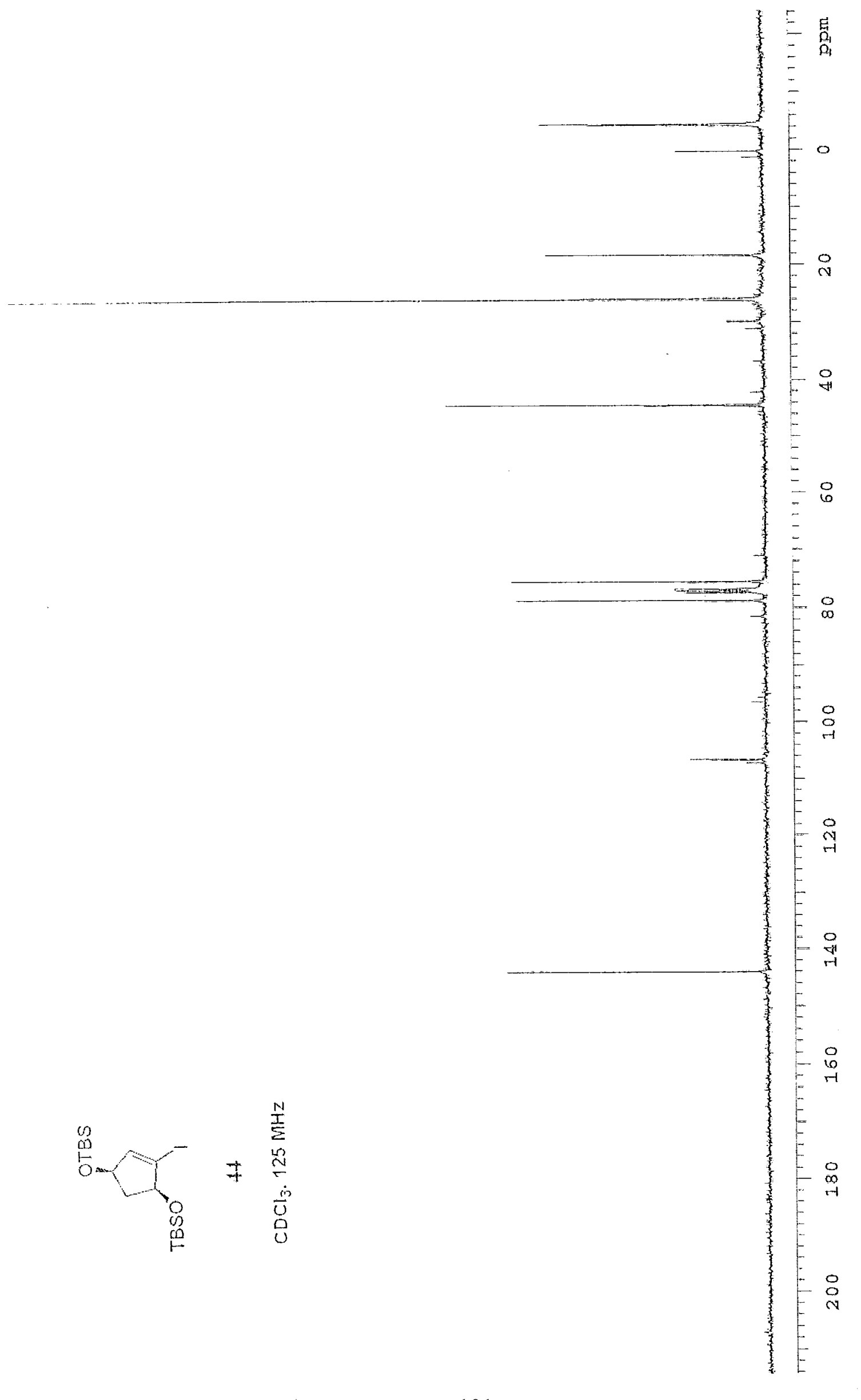




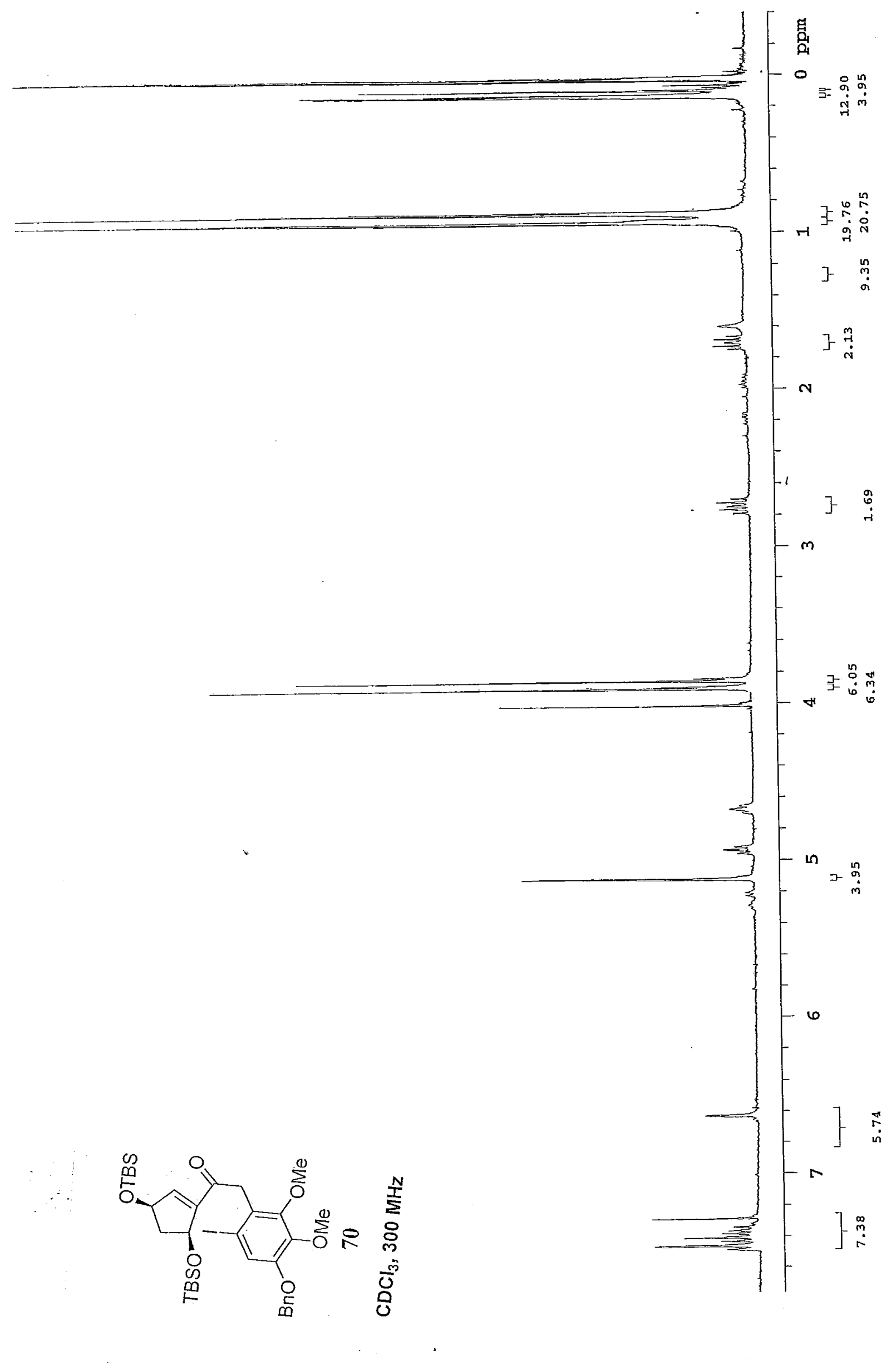




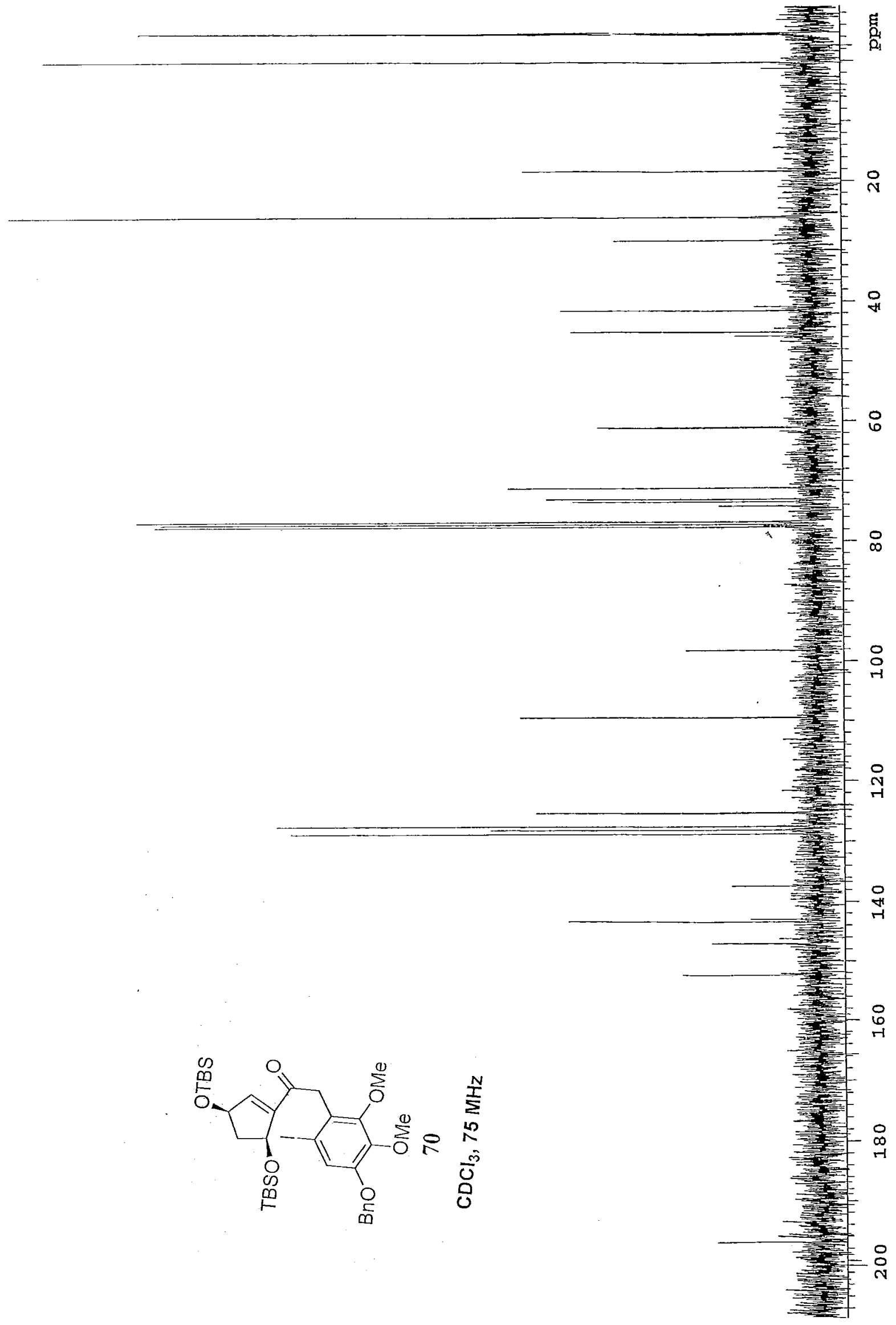




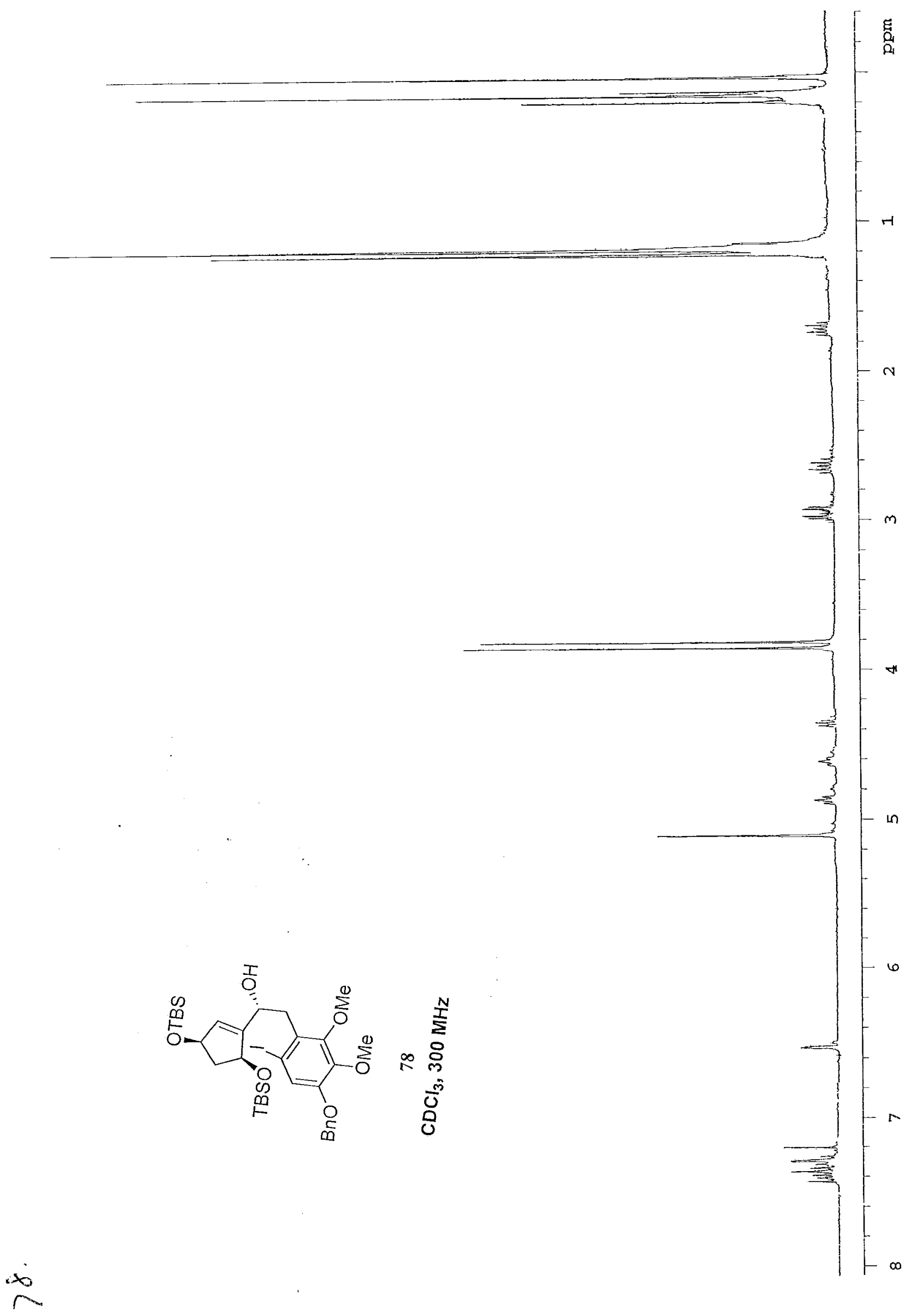




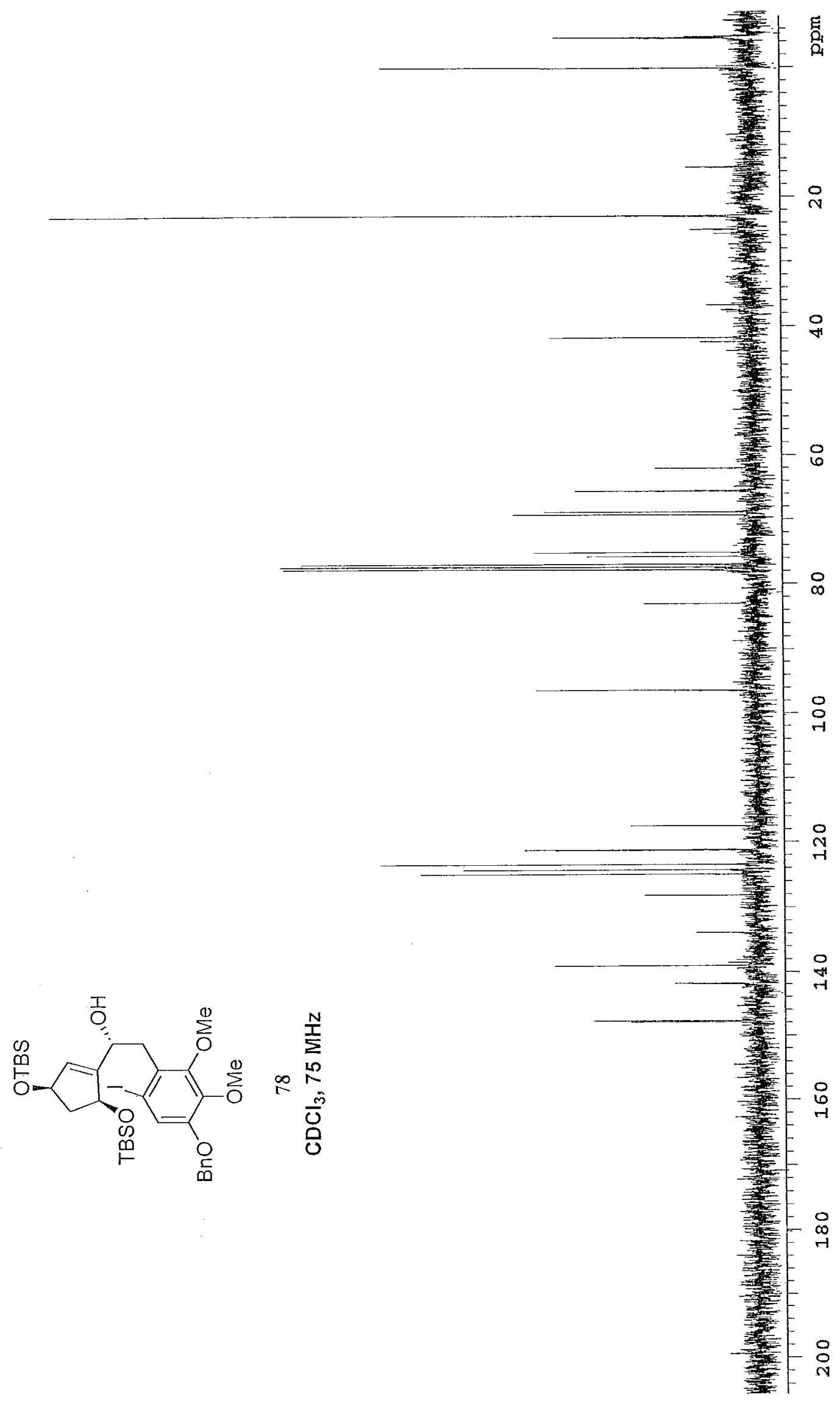

$x^{2}$ 


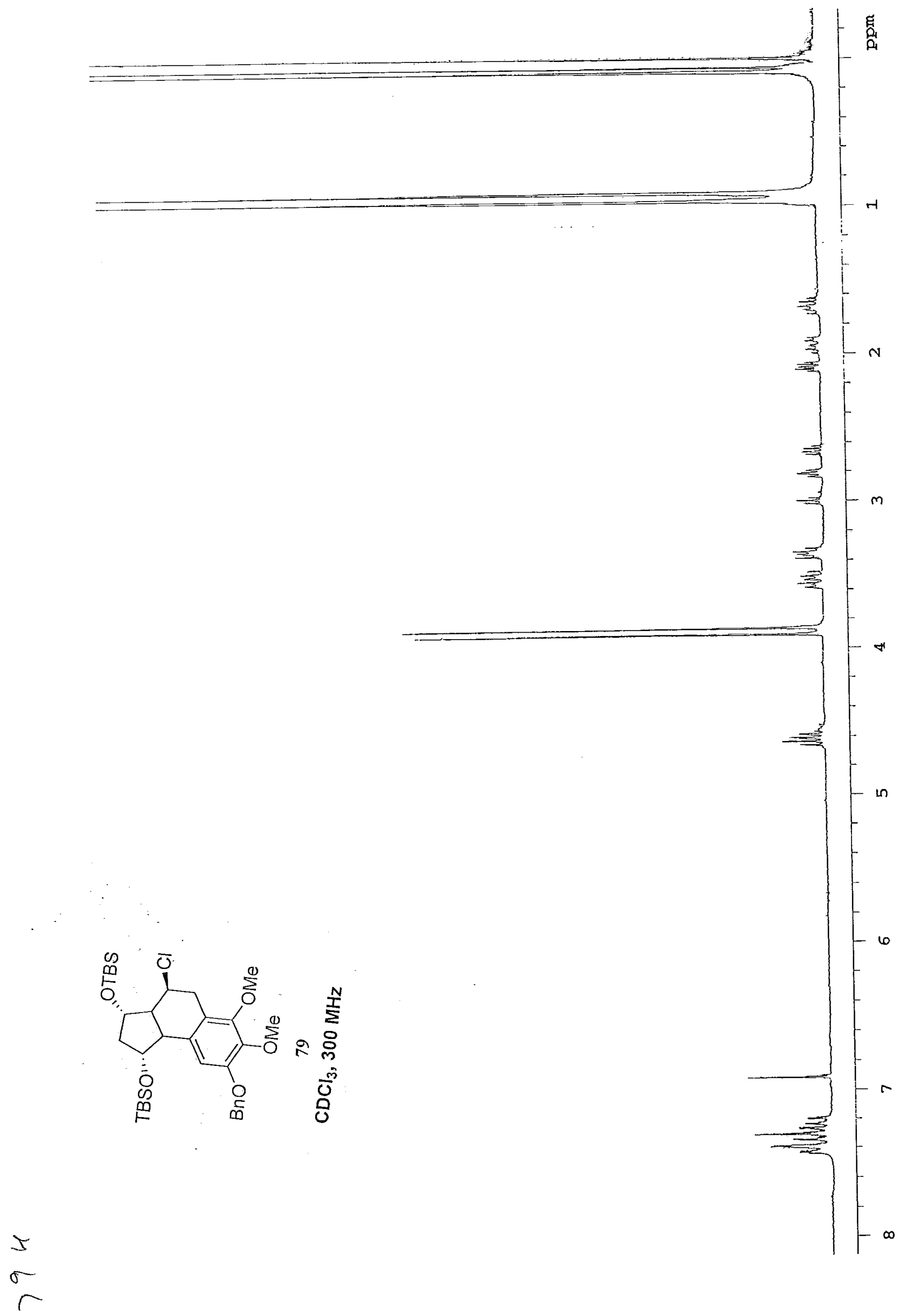




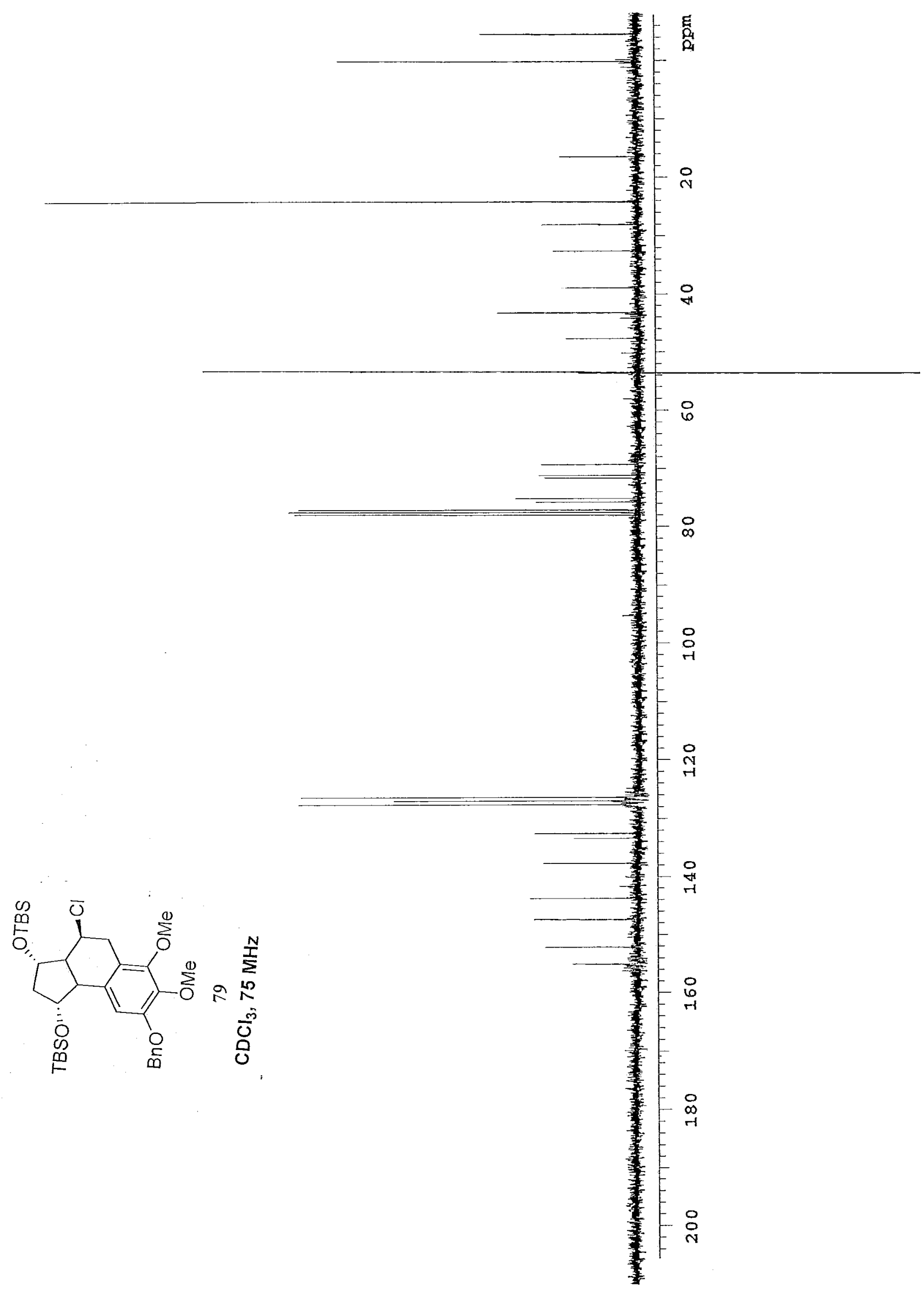




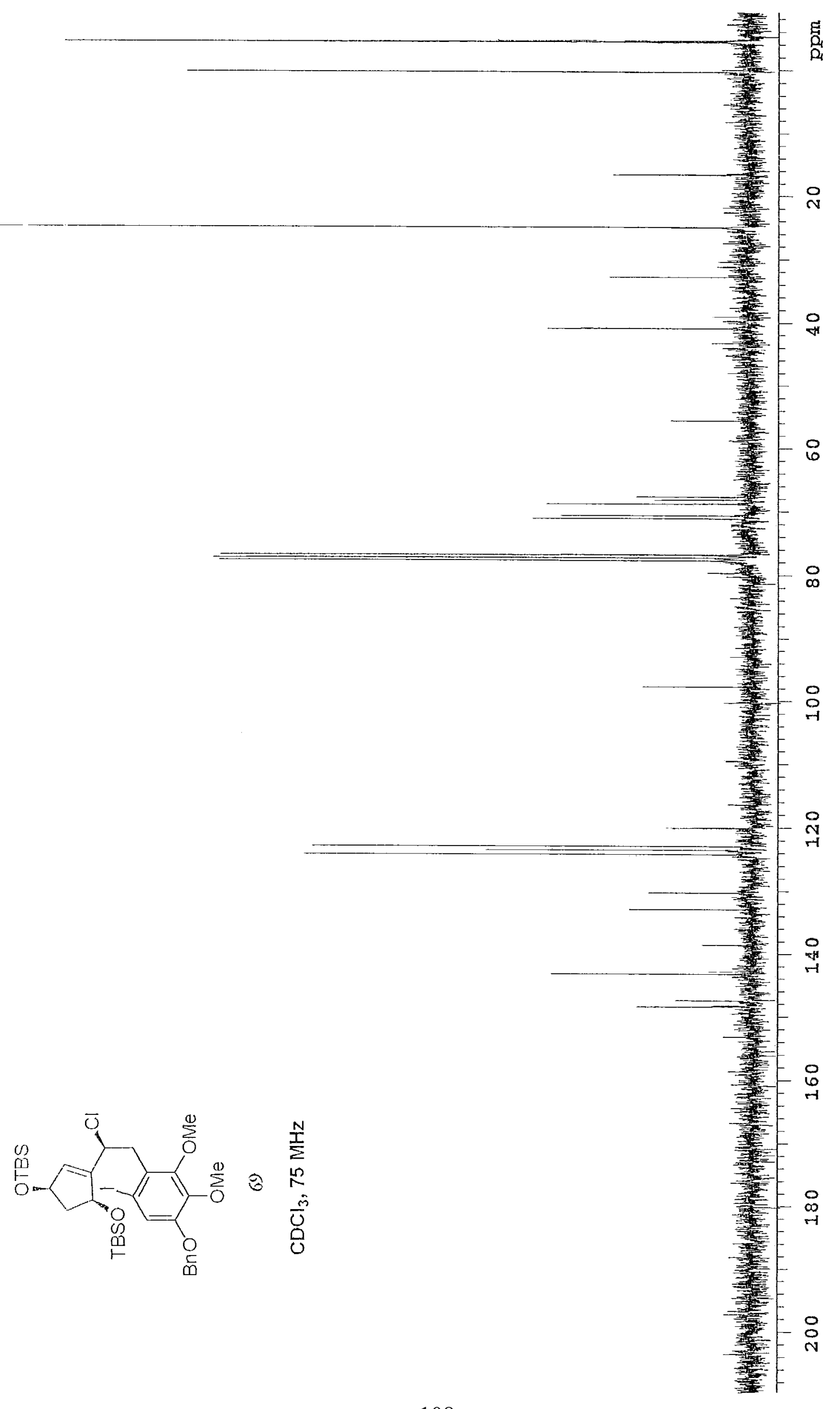




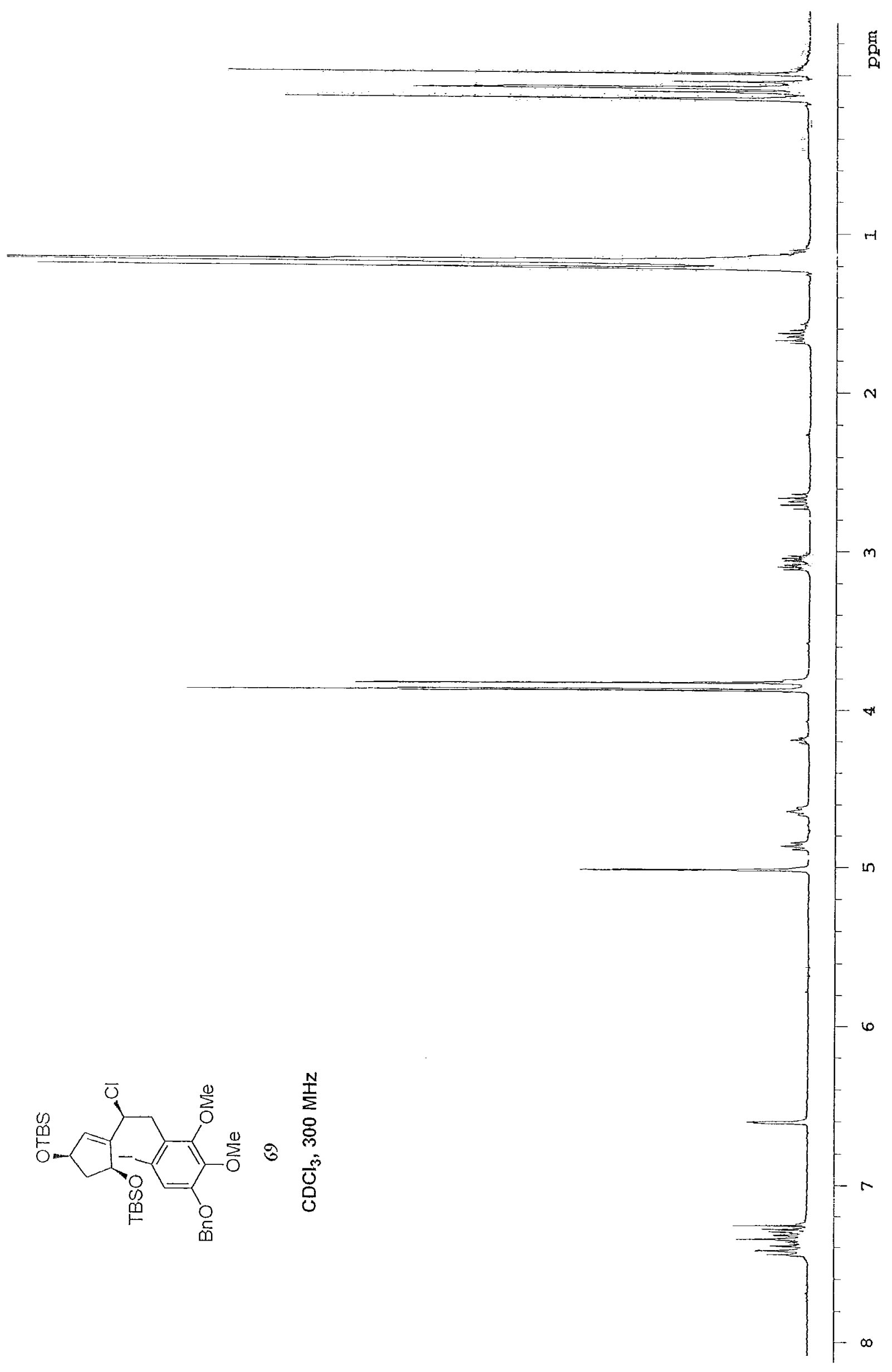




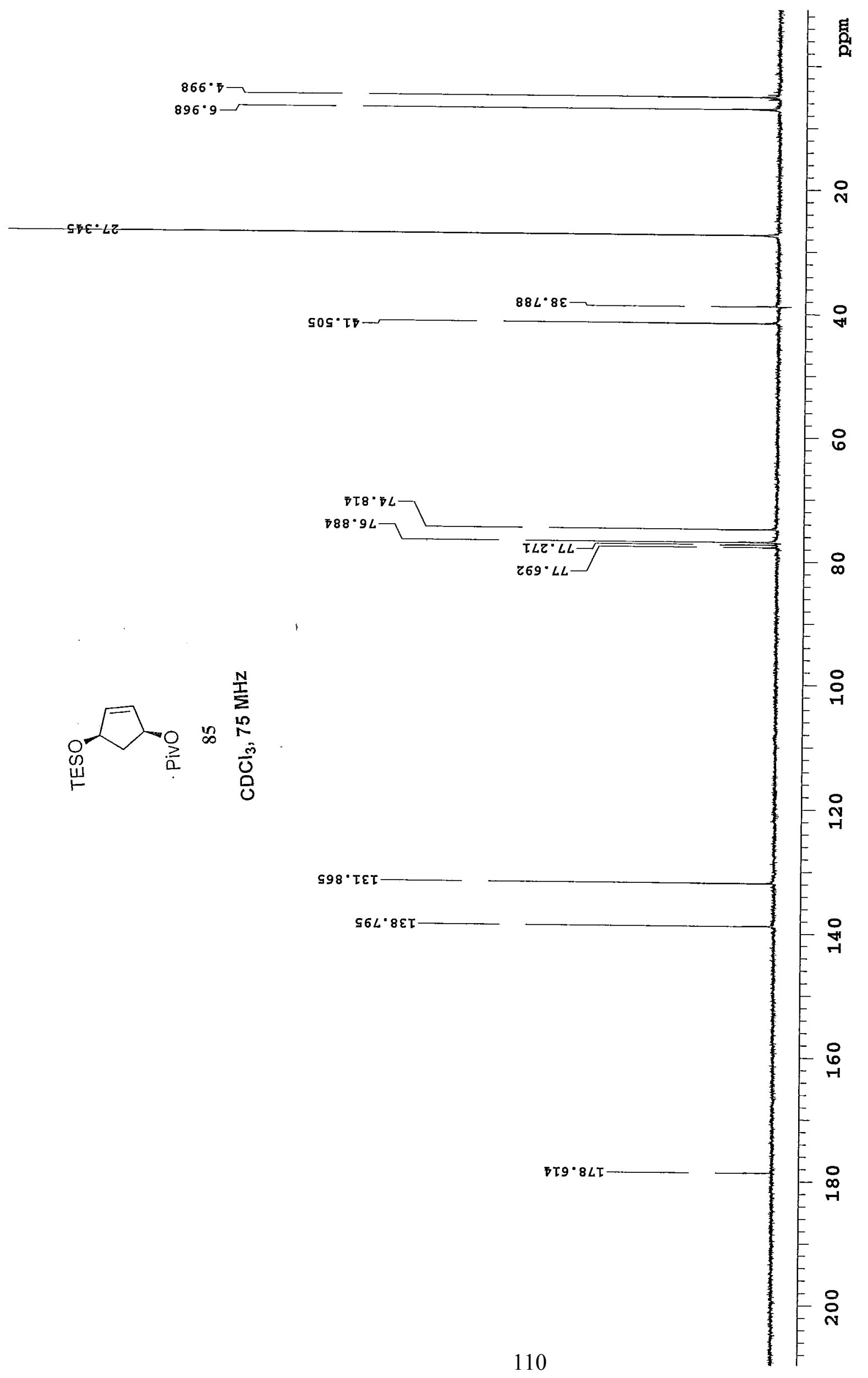




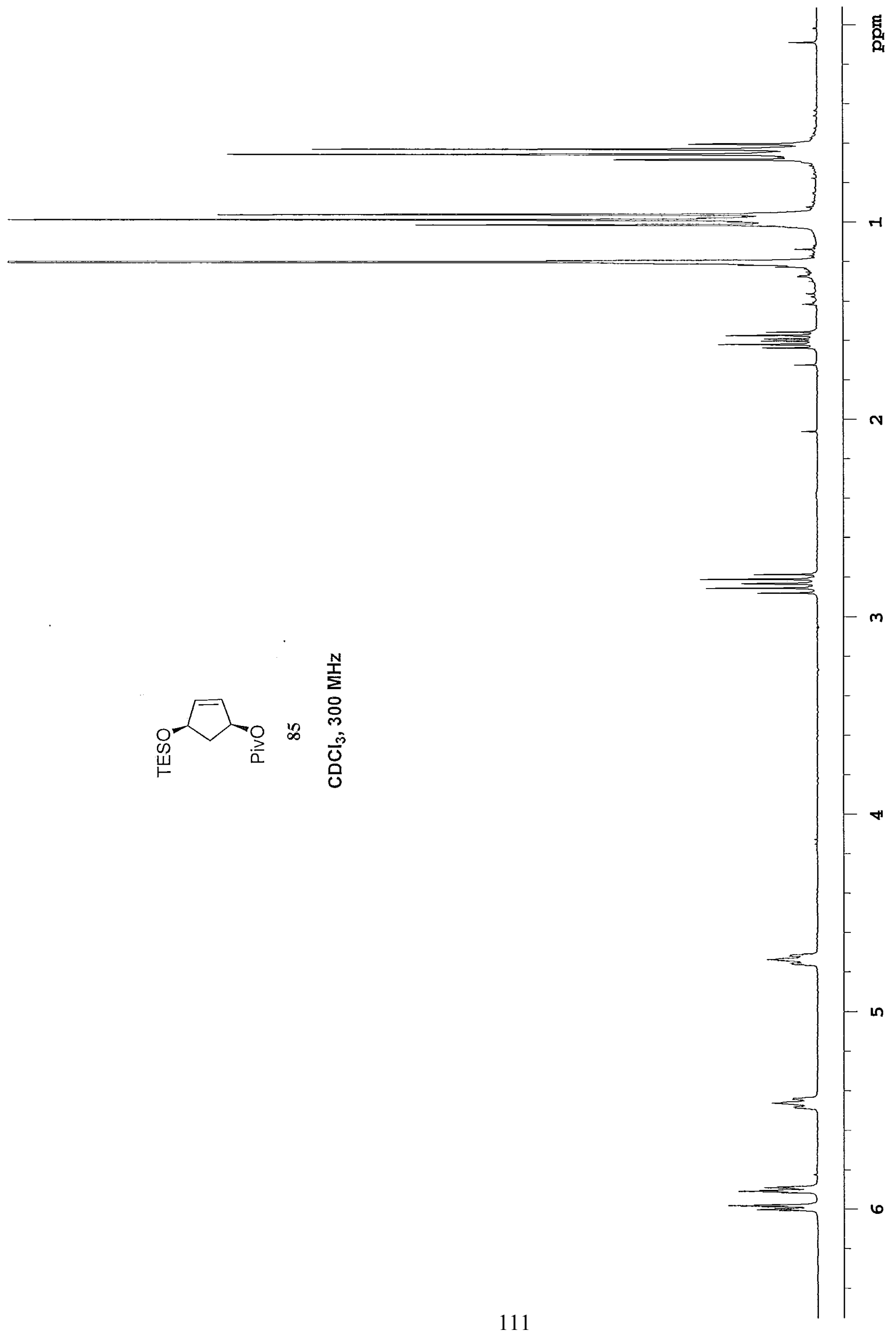




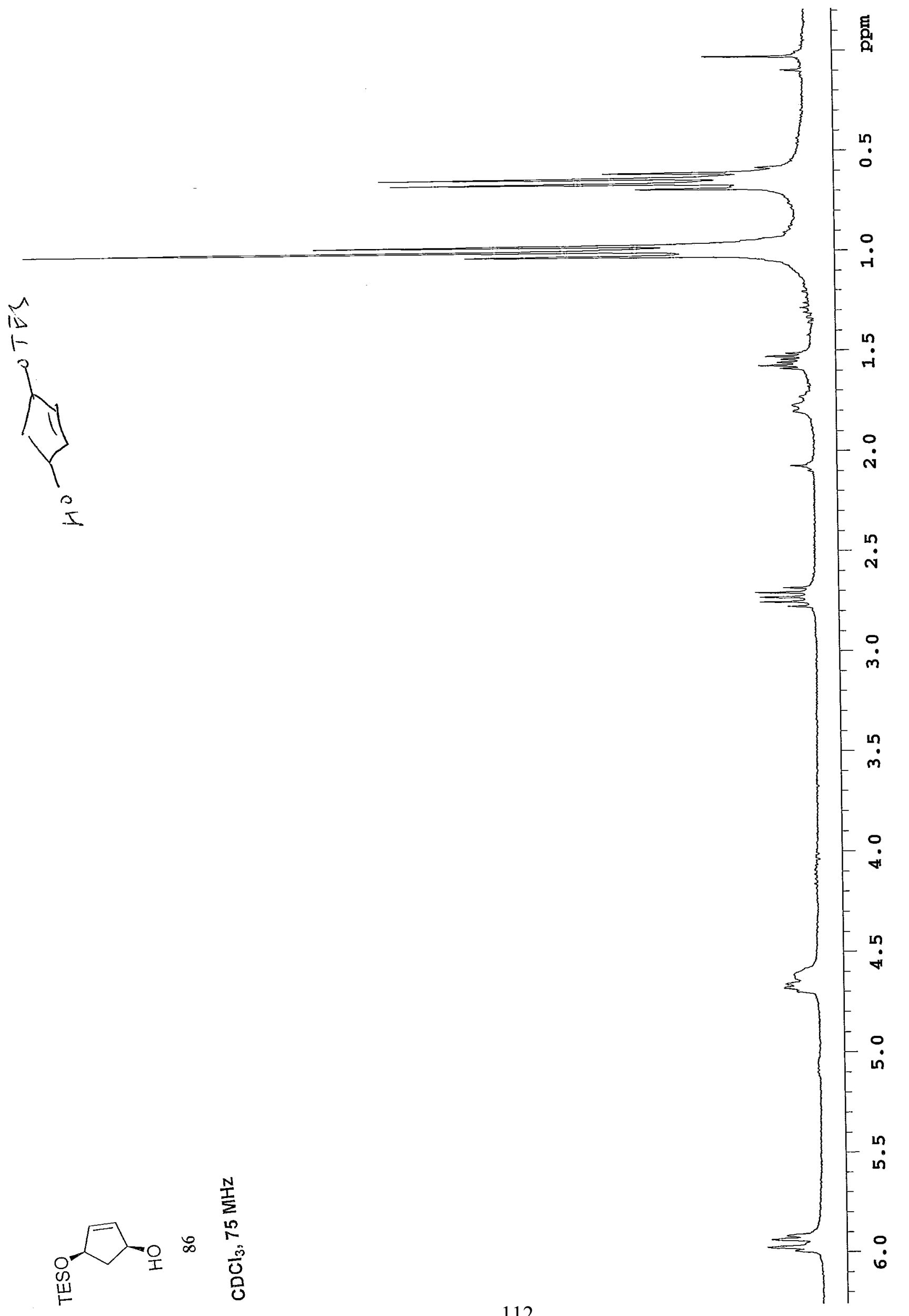




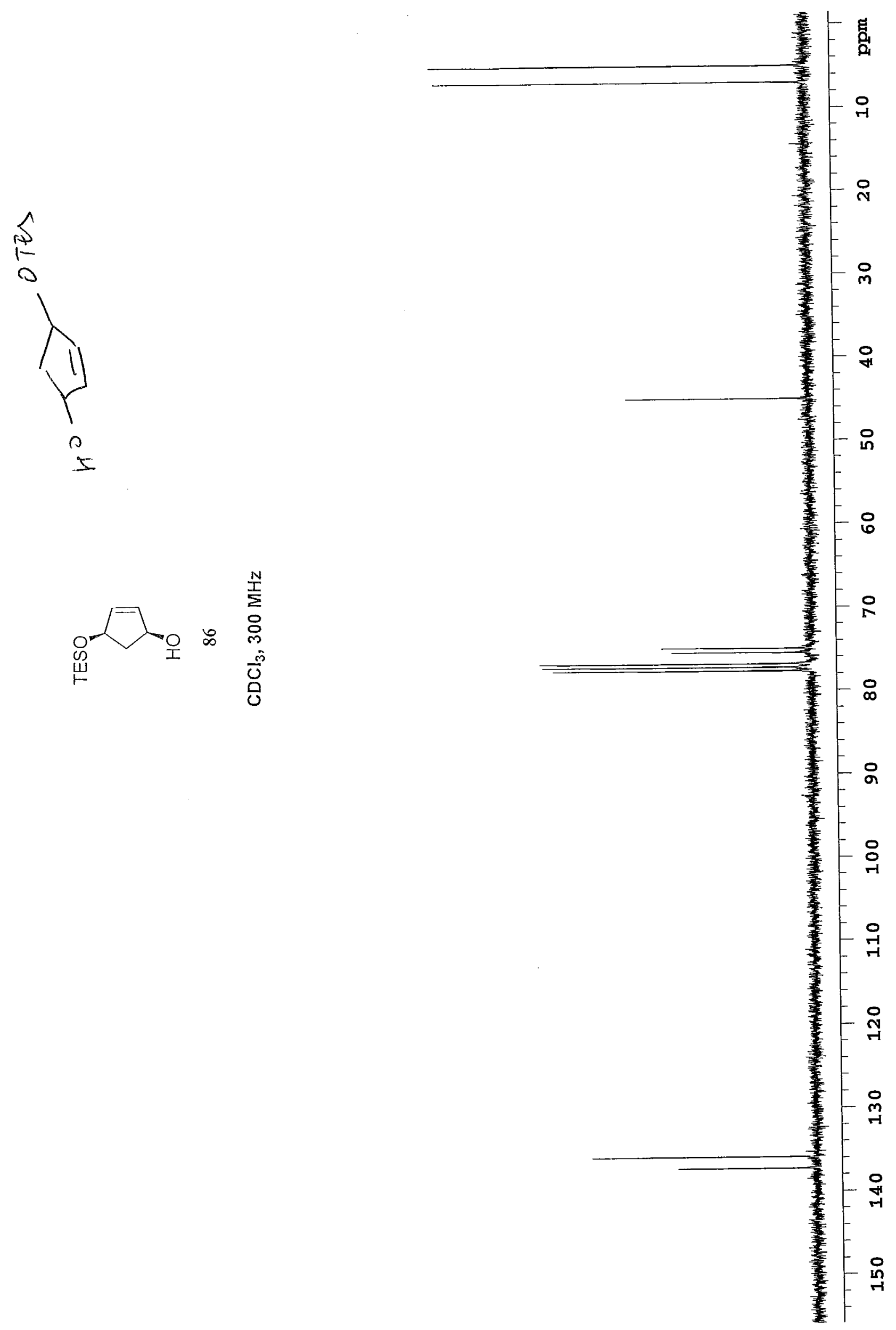



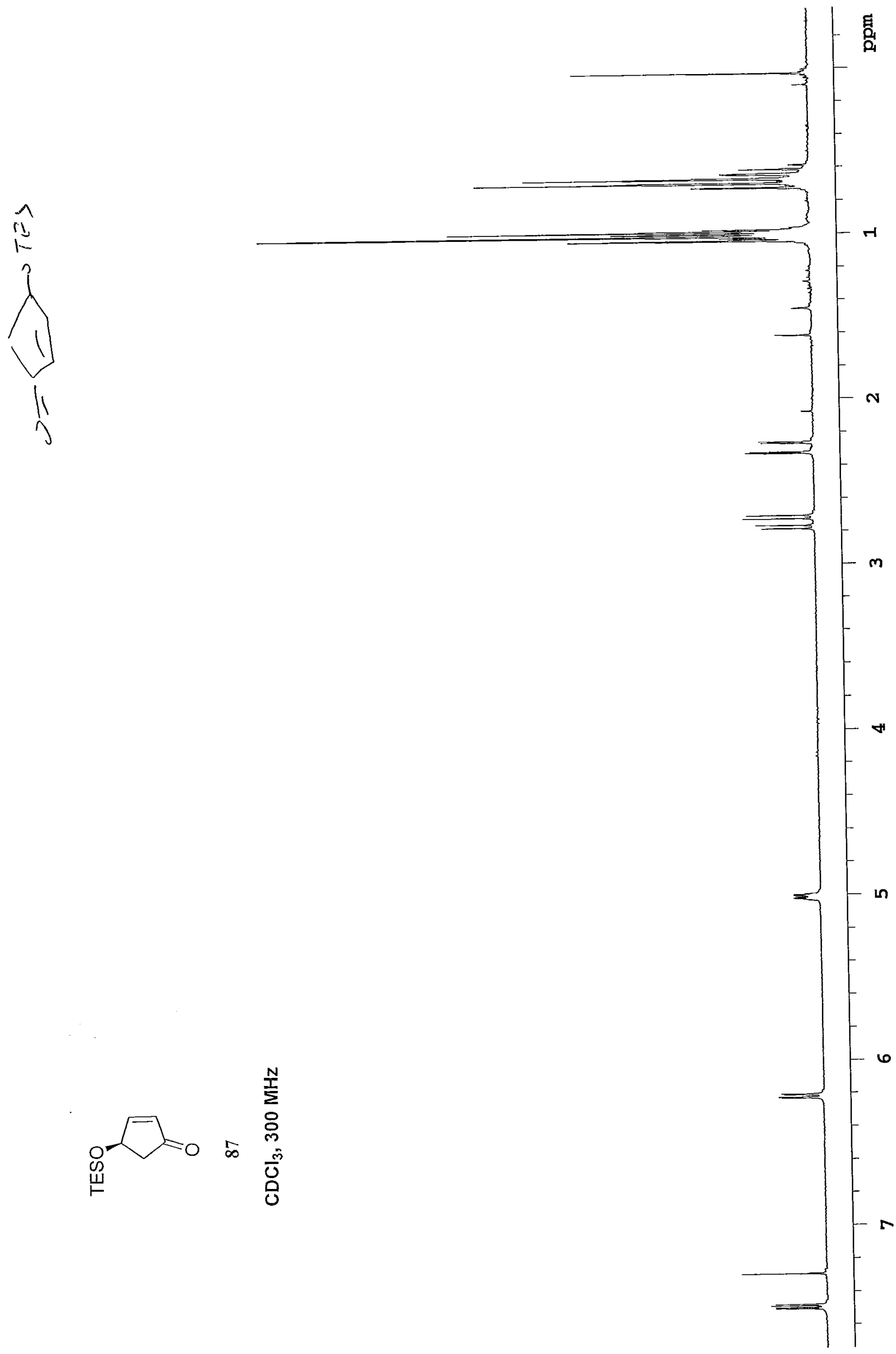

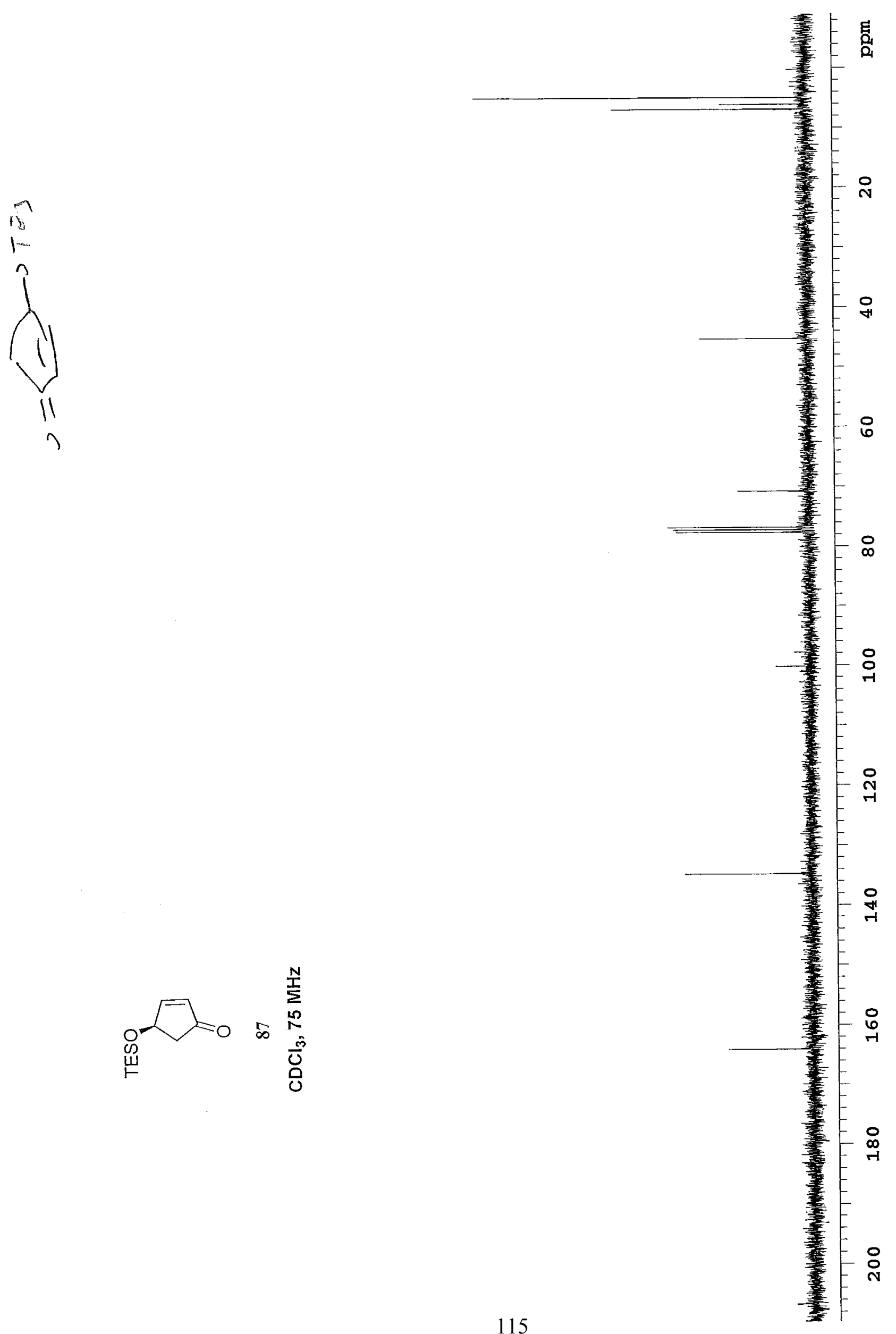


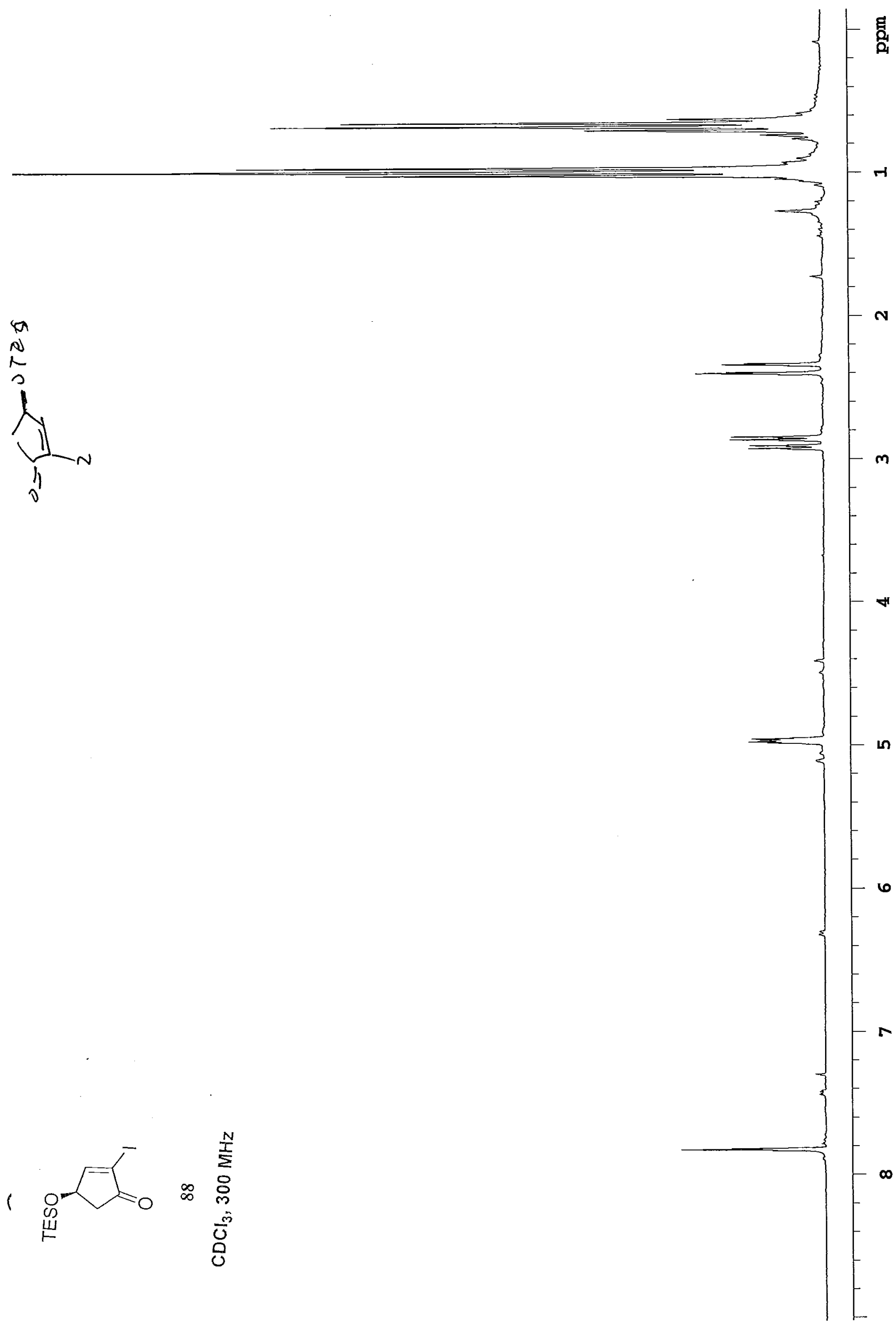




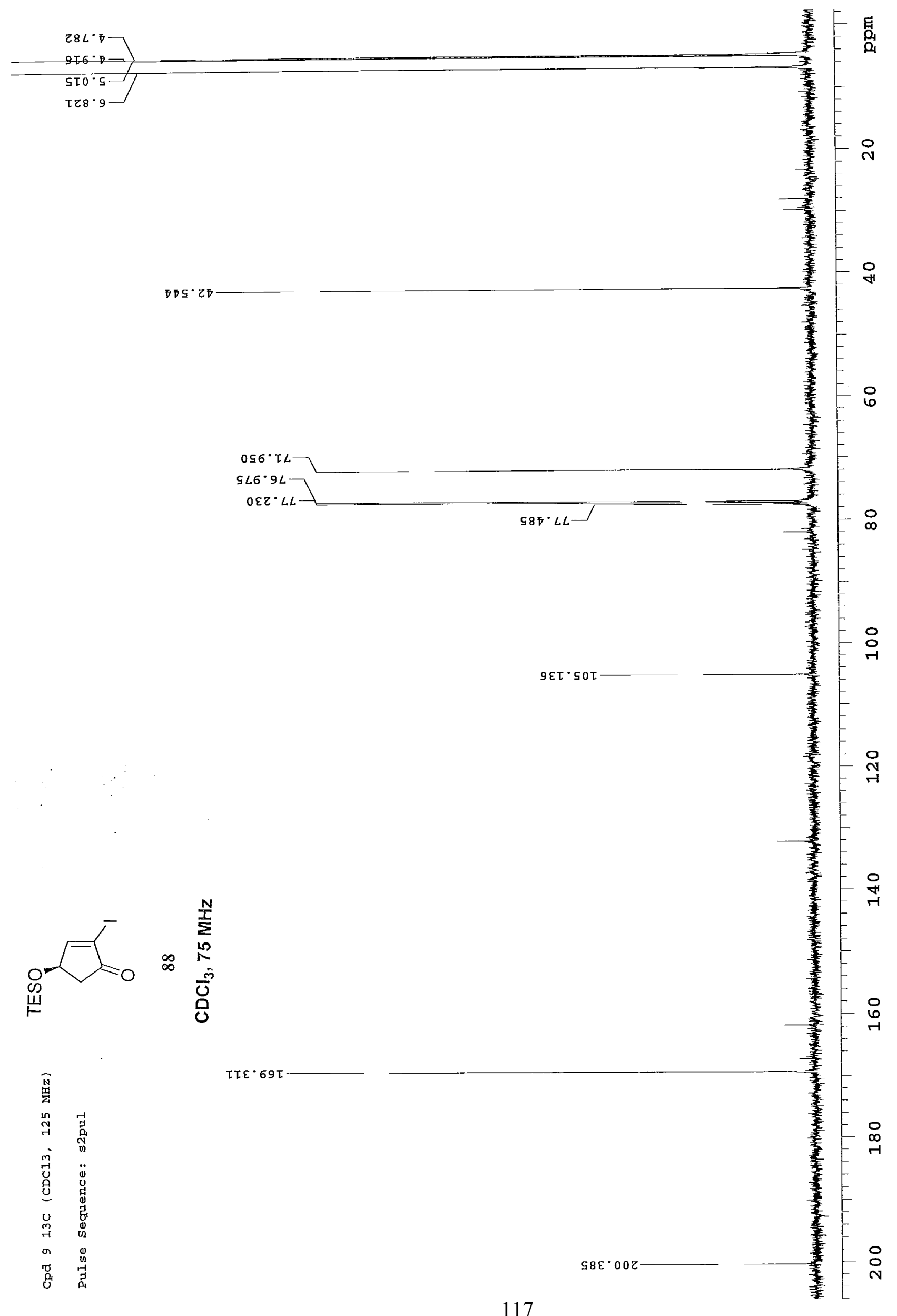




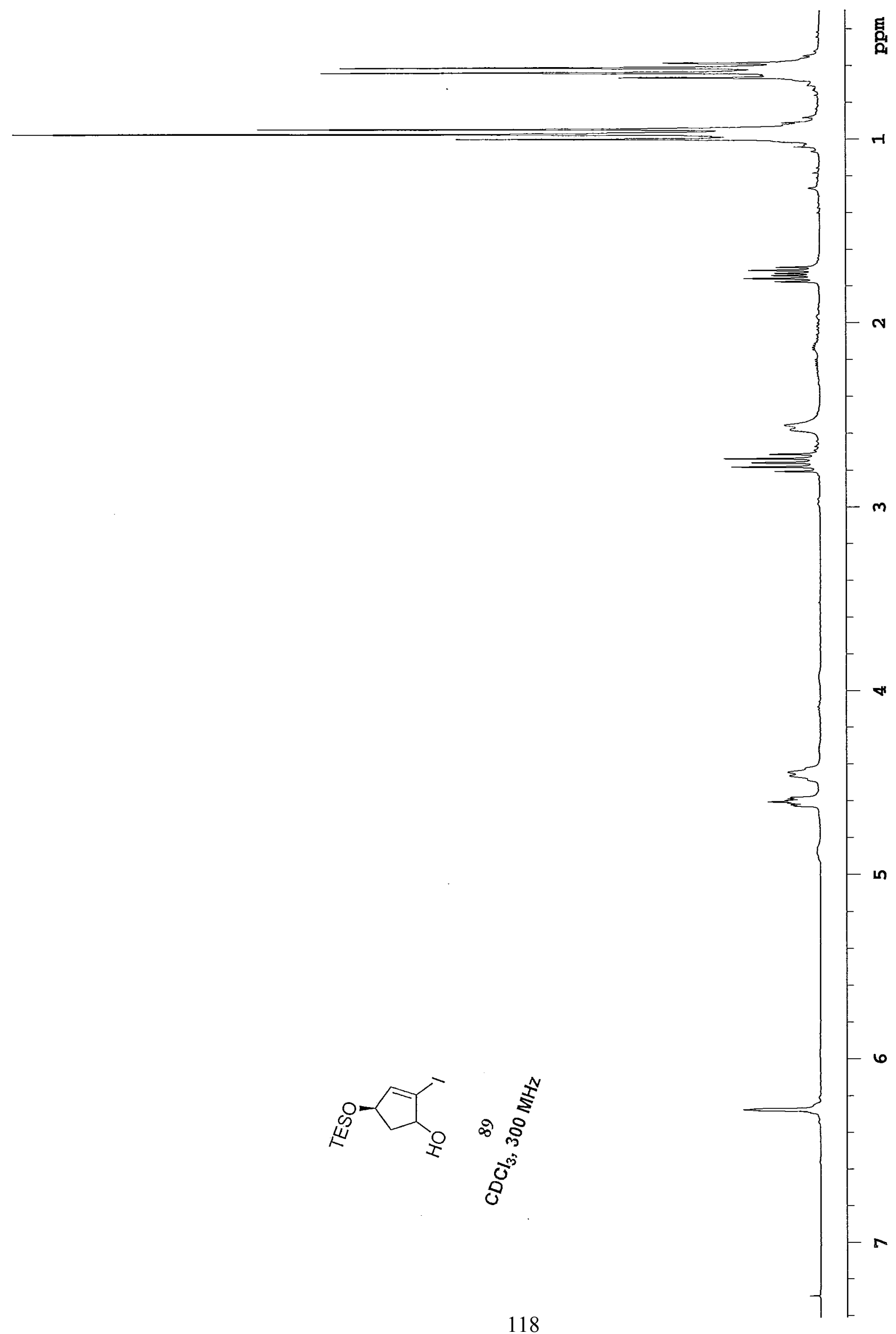




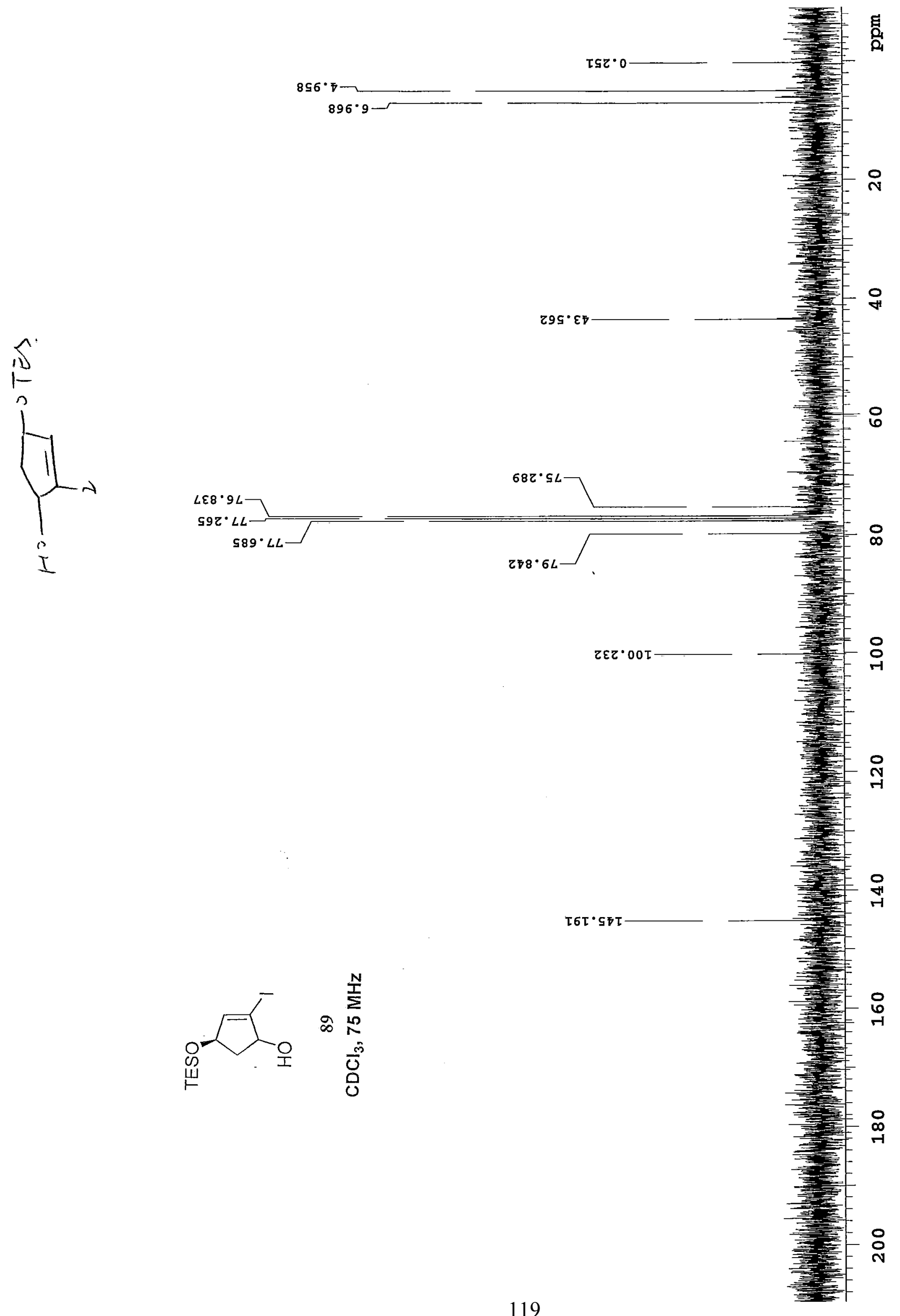



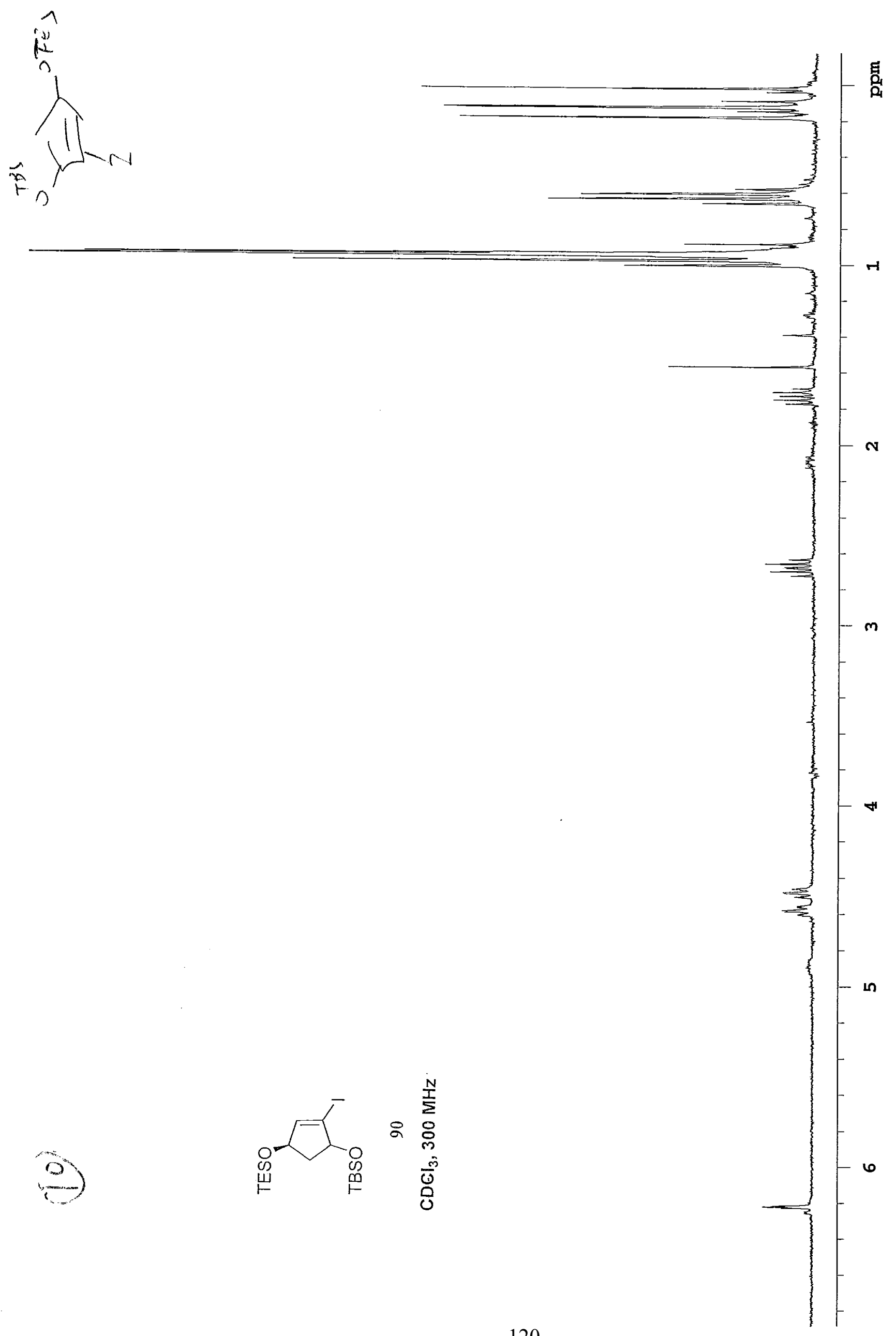

b) 


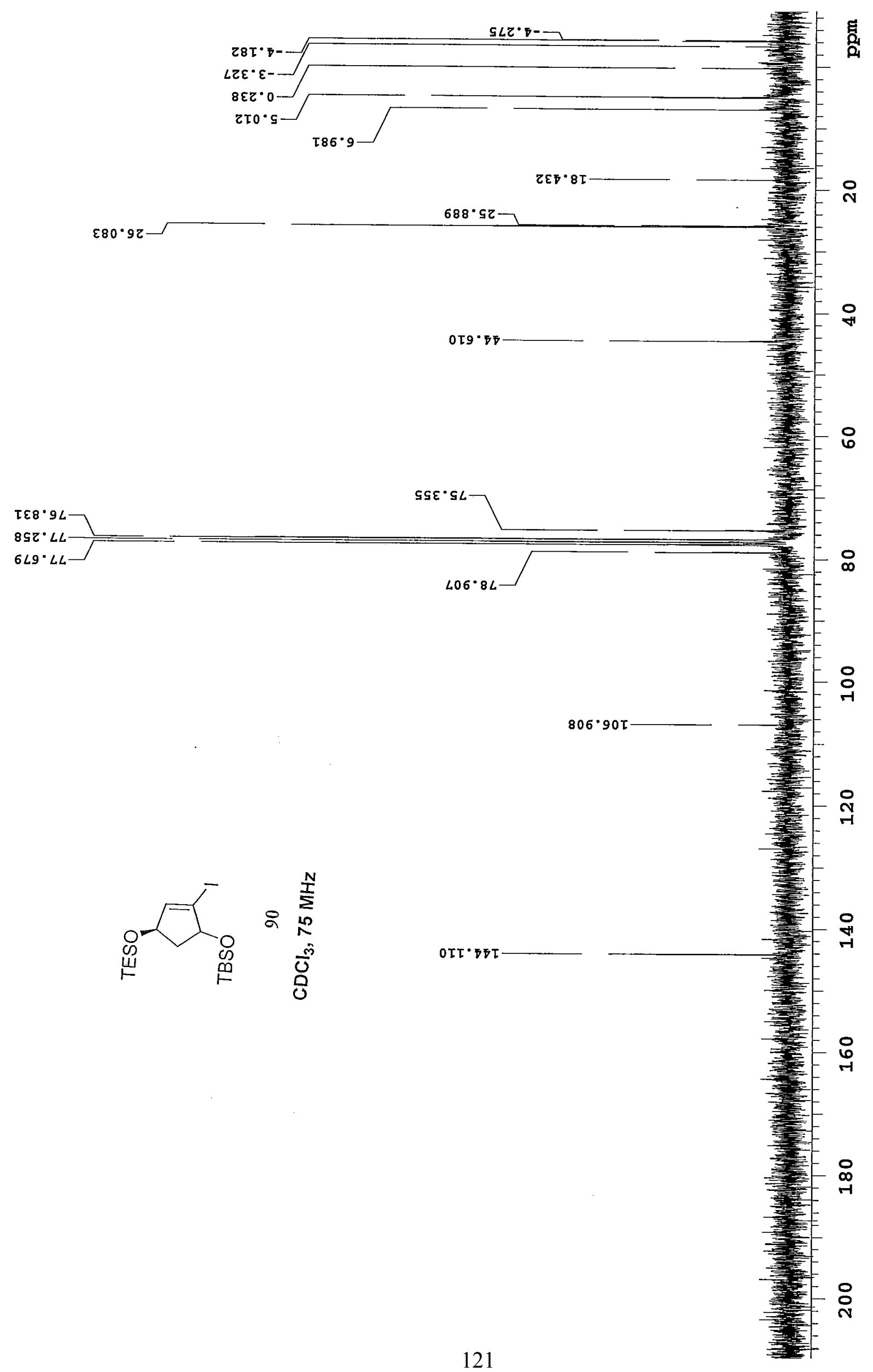


$\frac{2}{\lambda}$

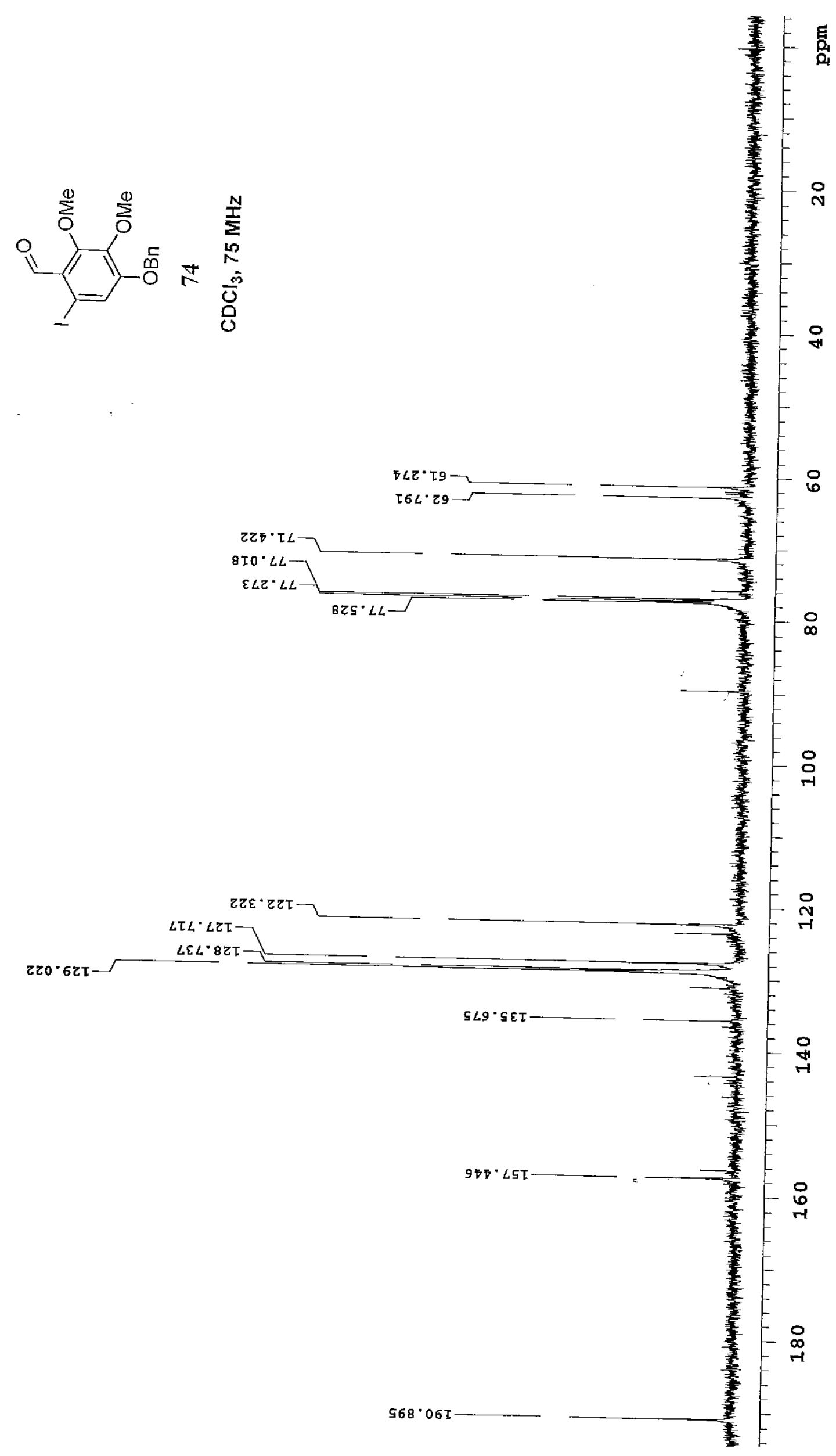


5
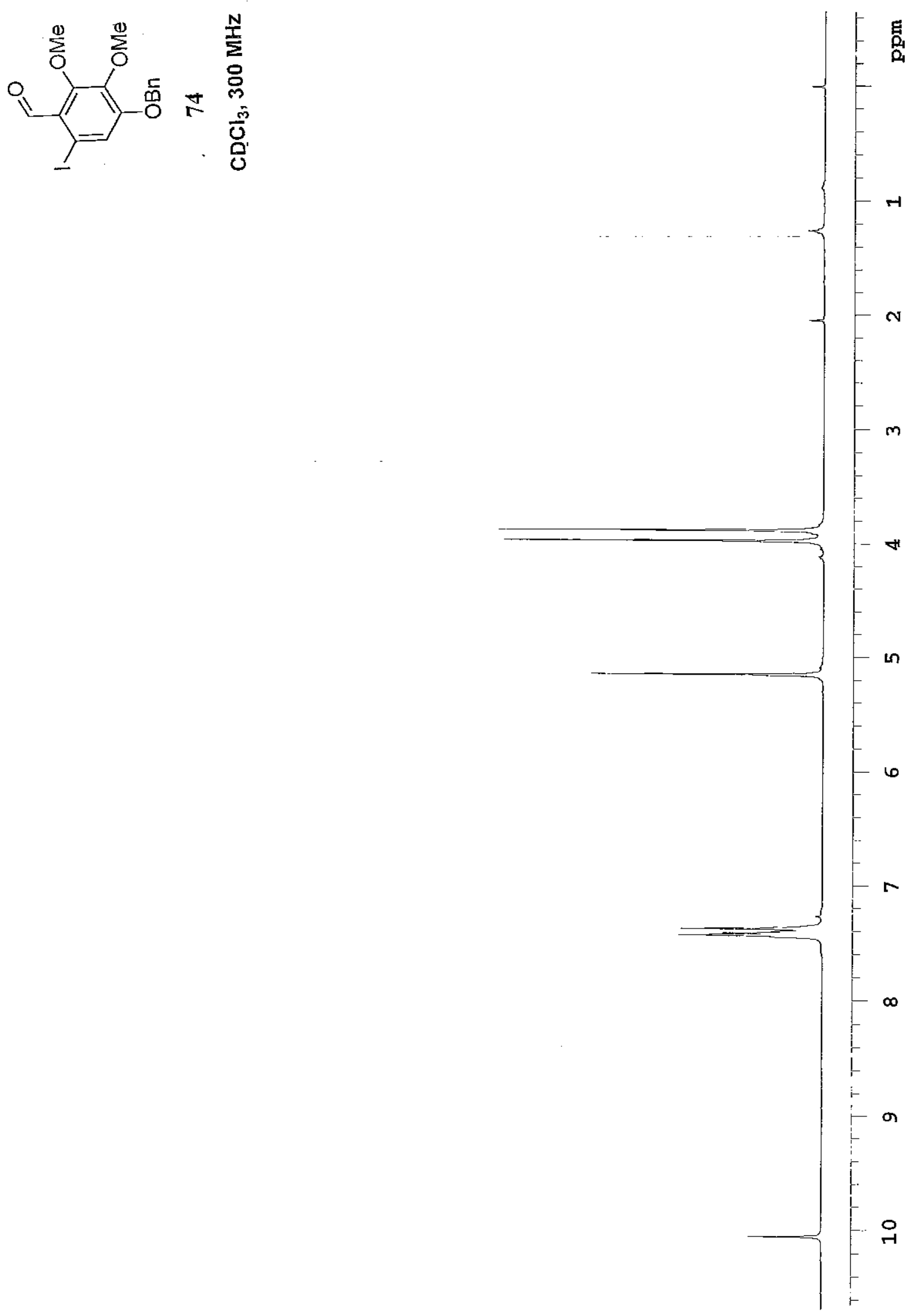


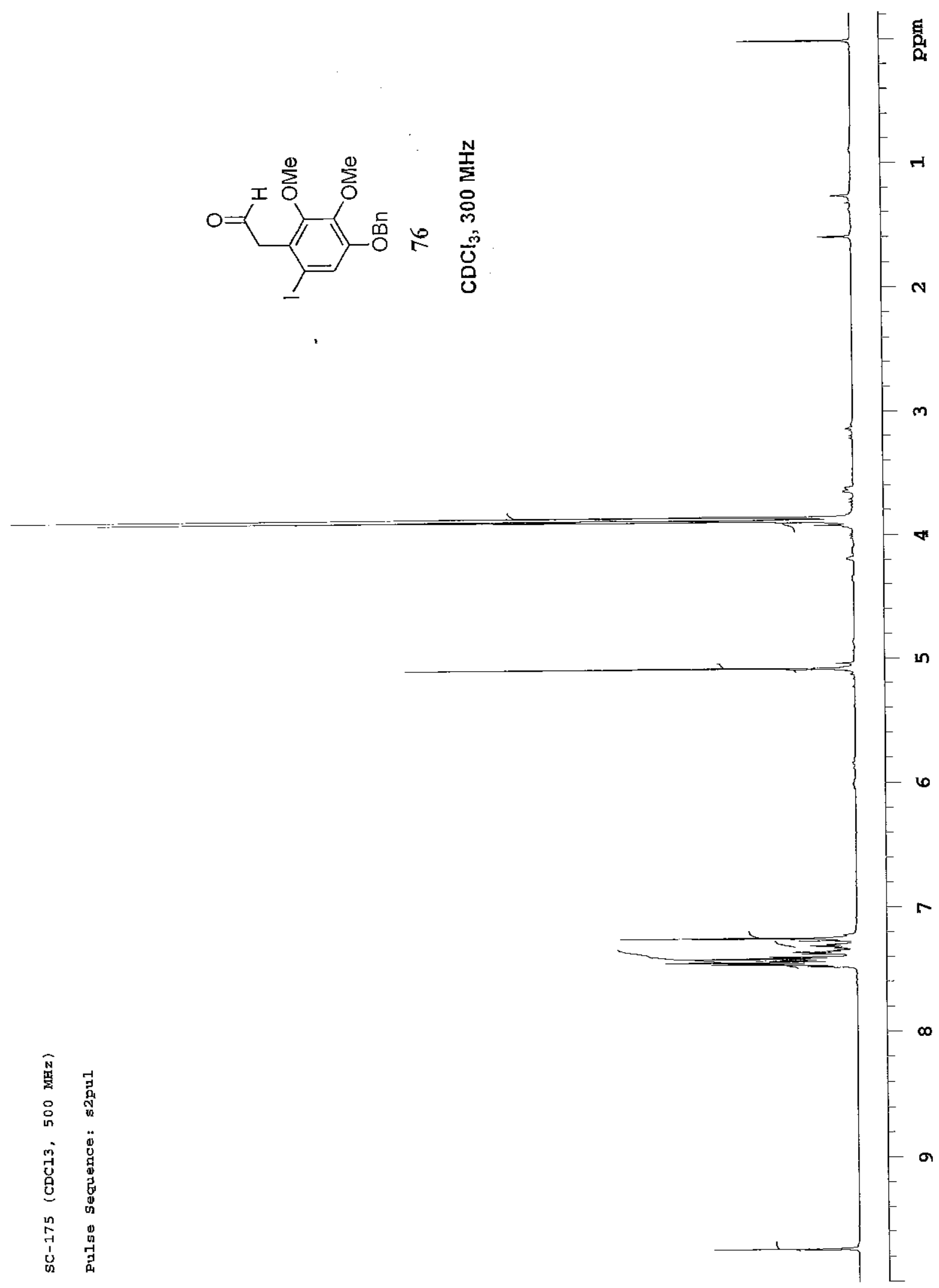




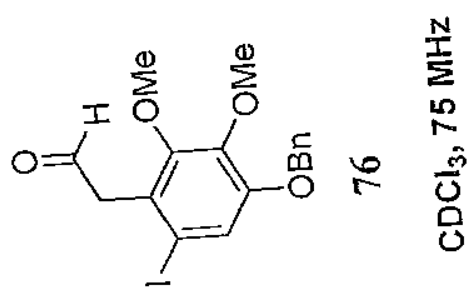

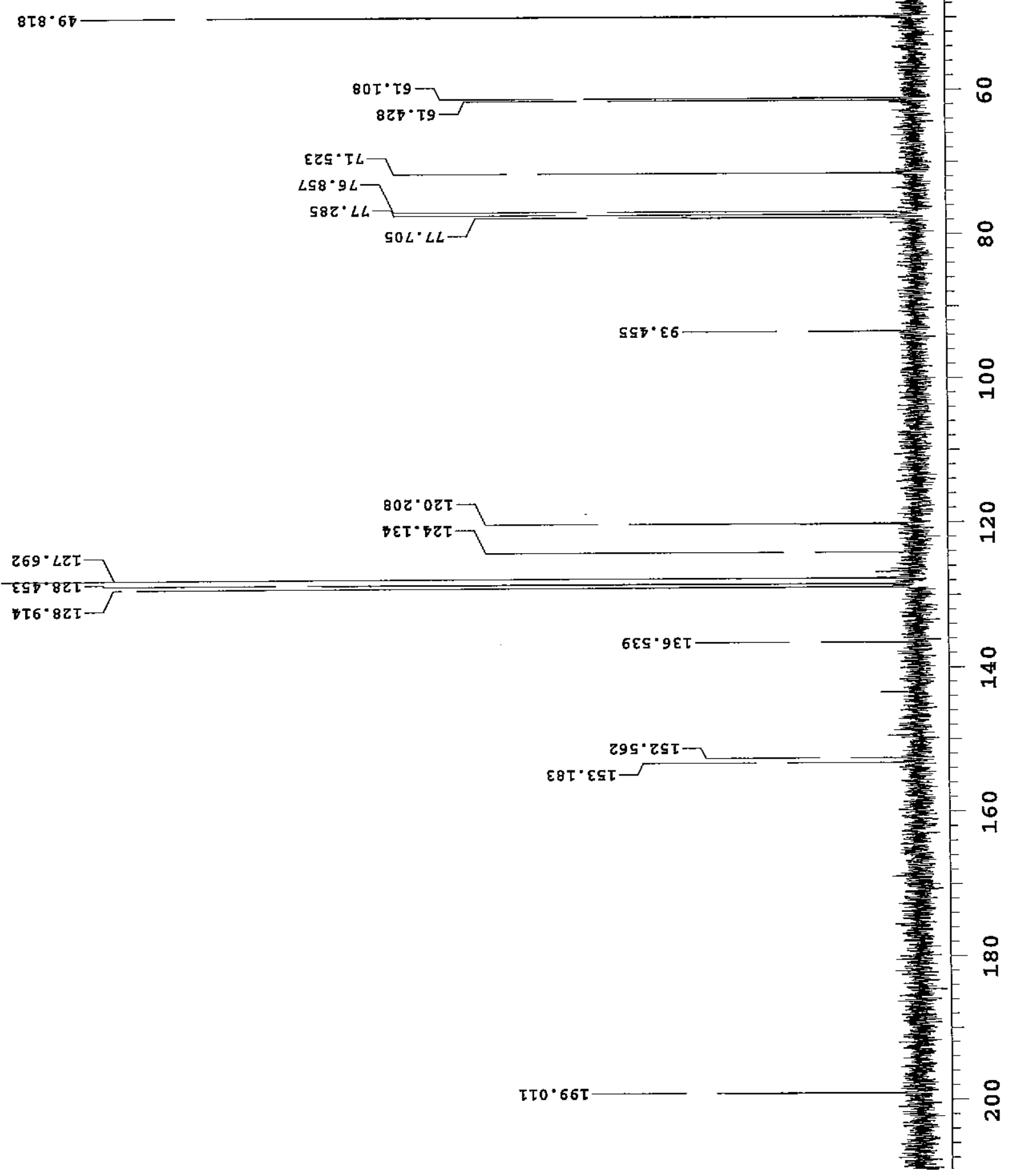




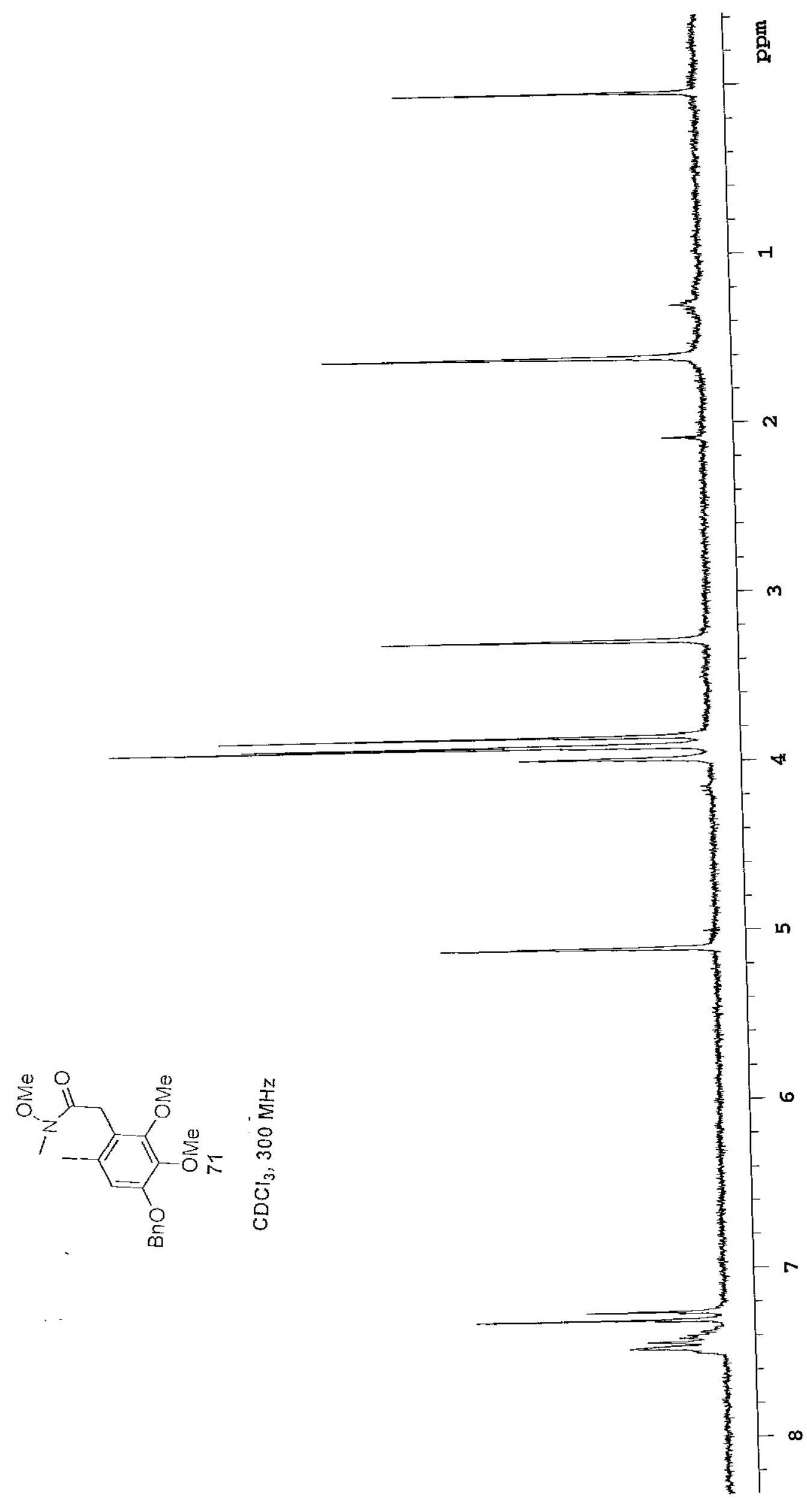




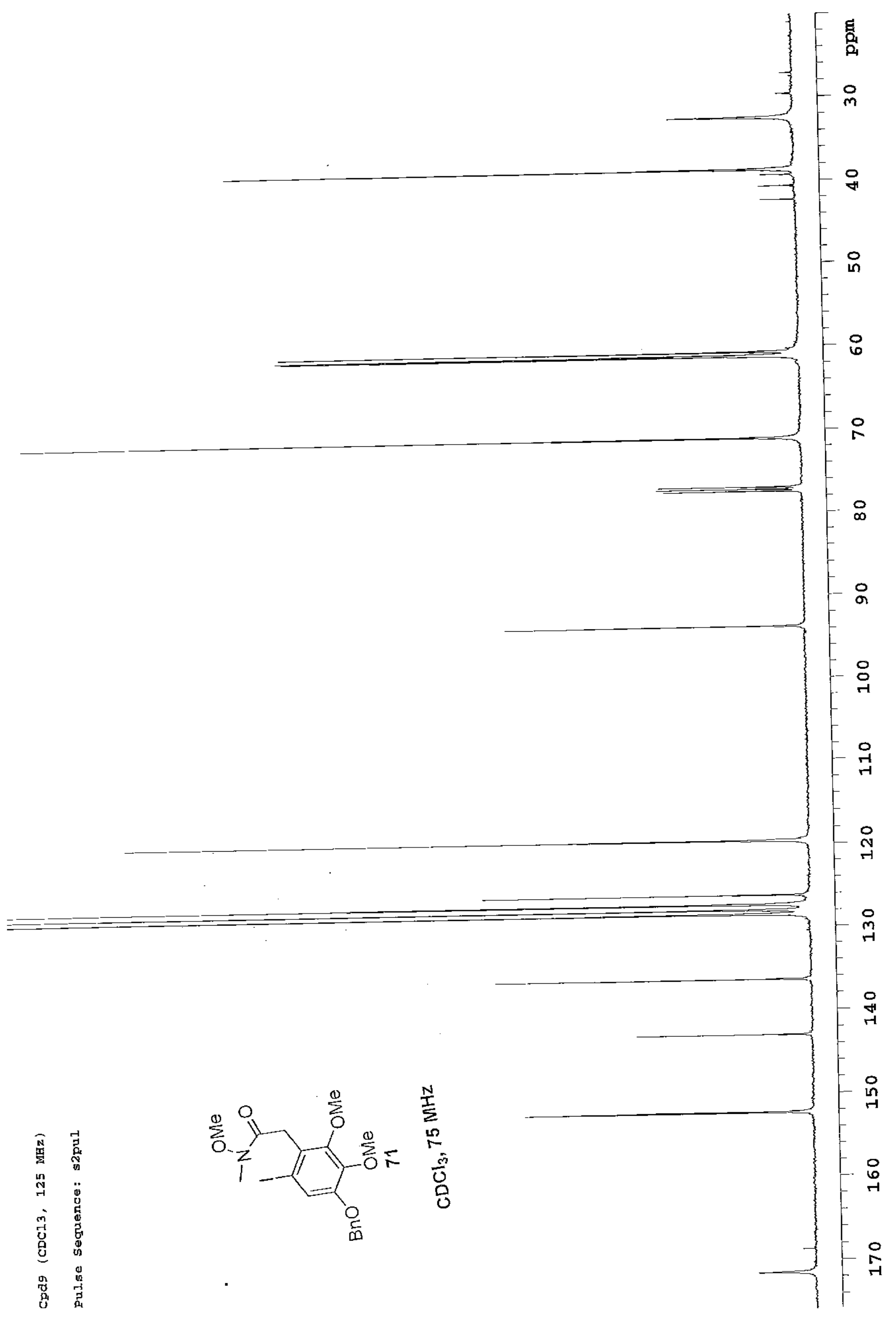




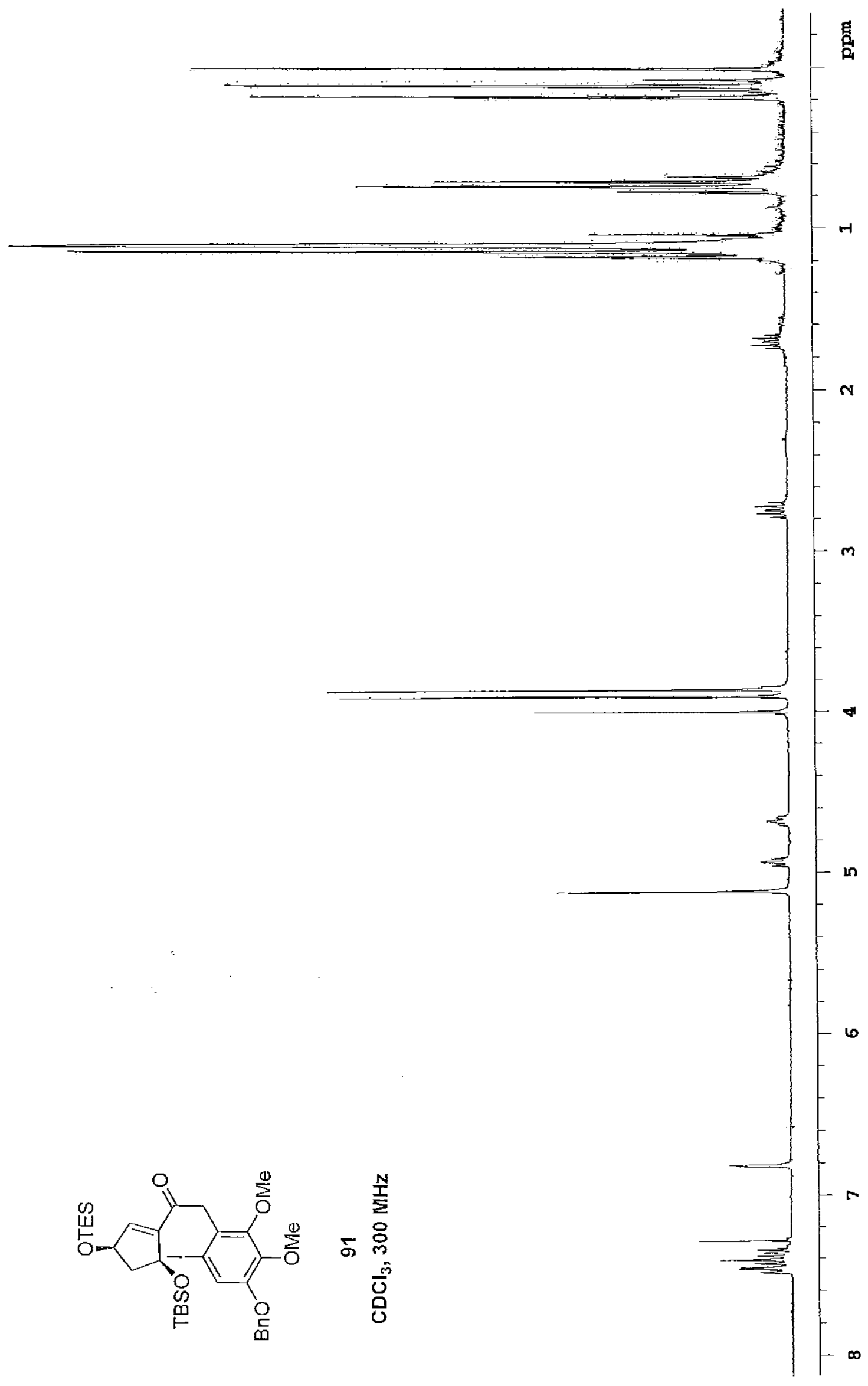

$\theta$ 


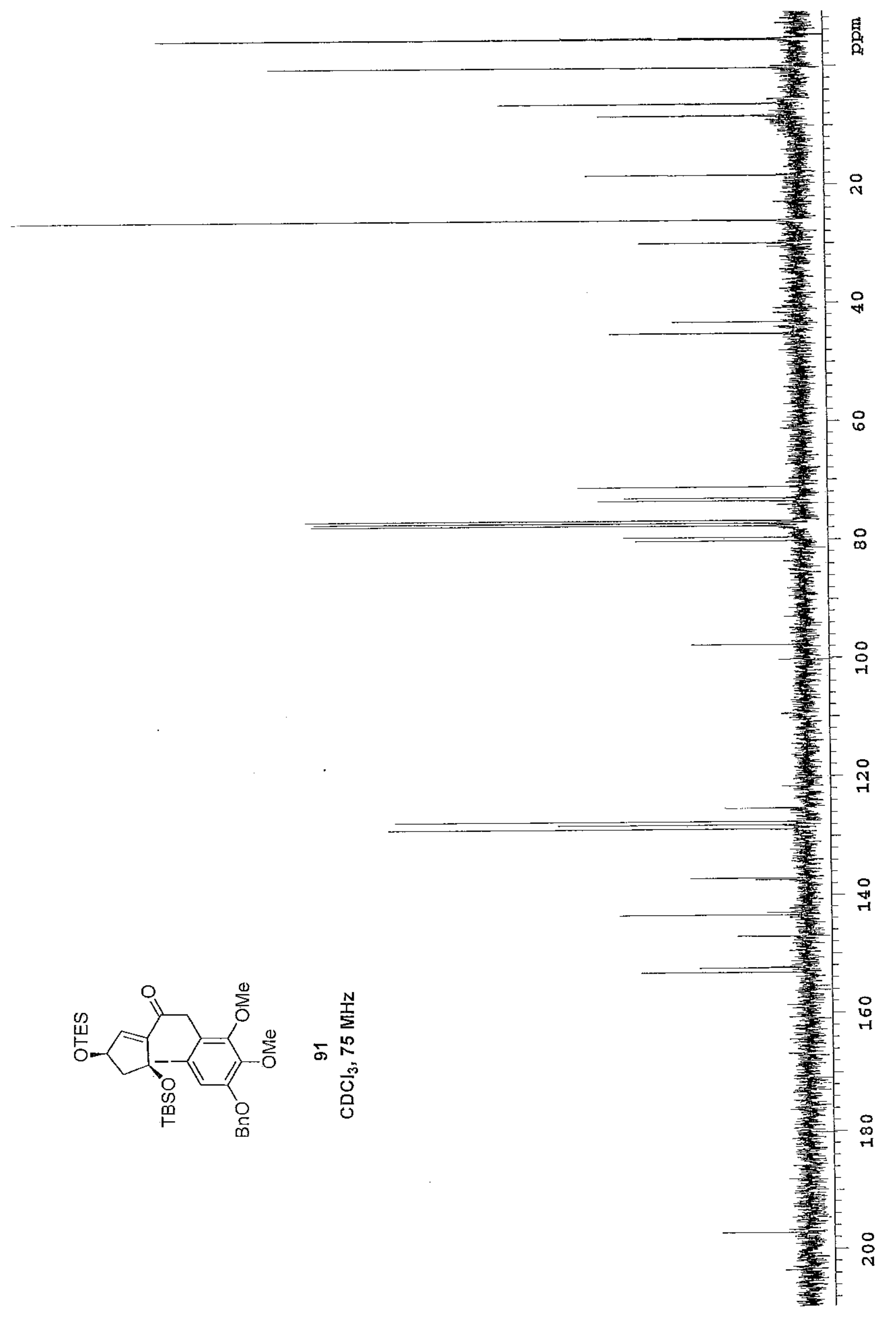




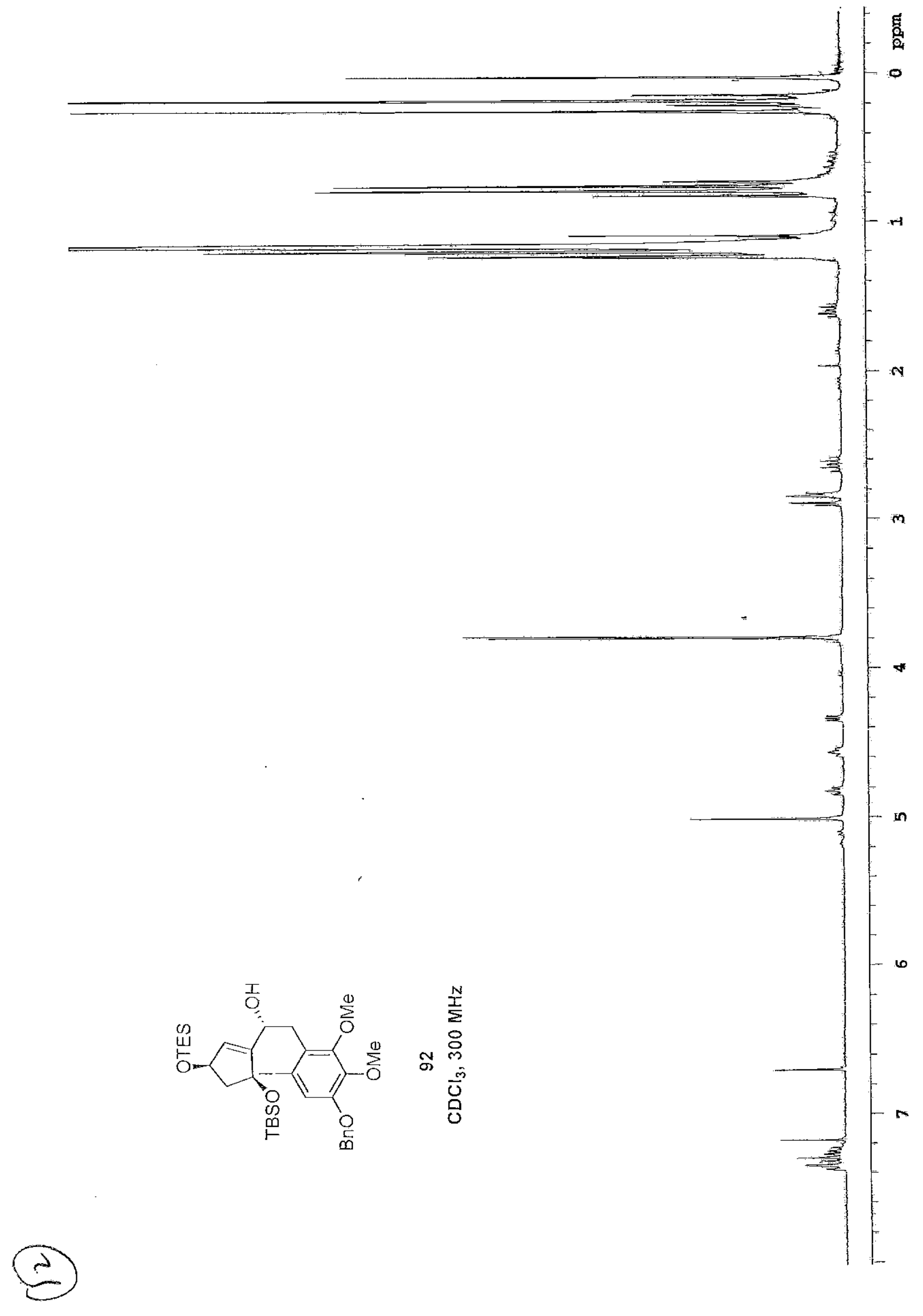




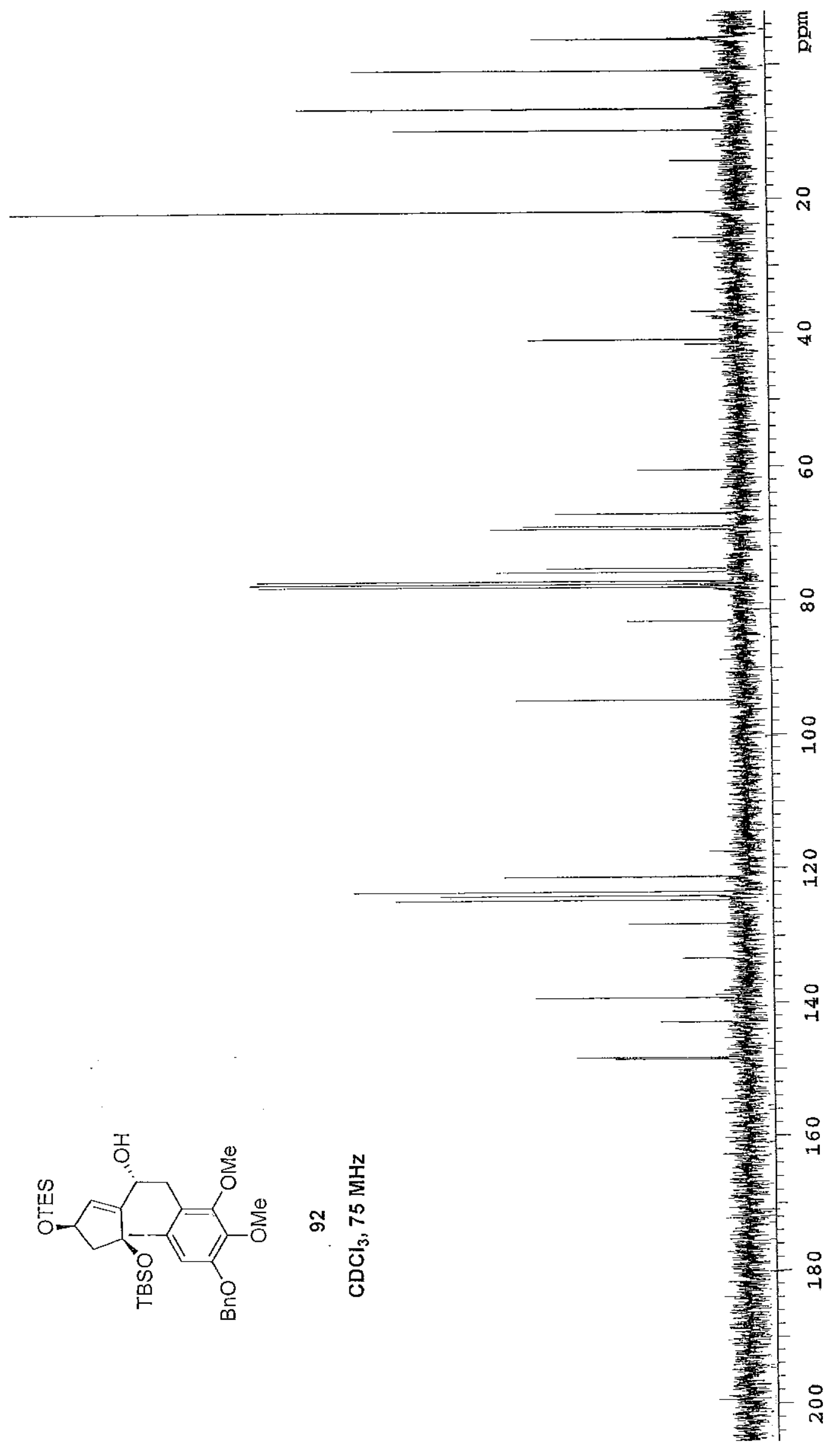




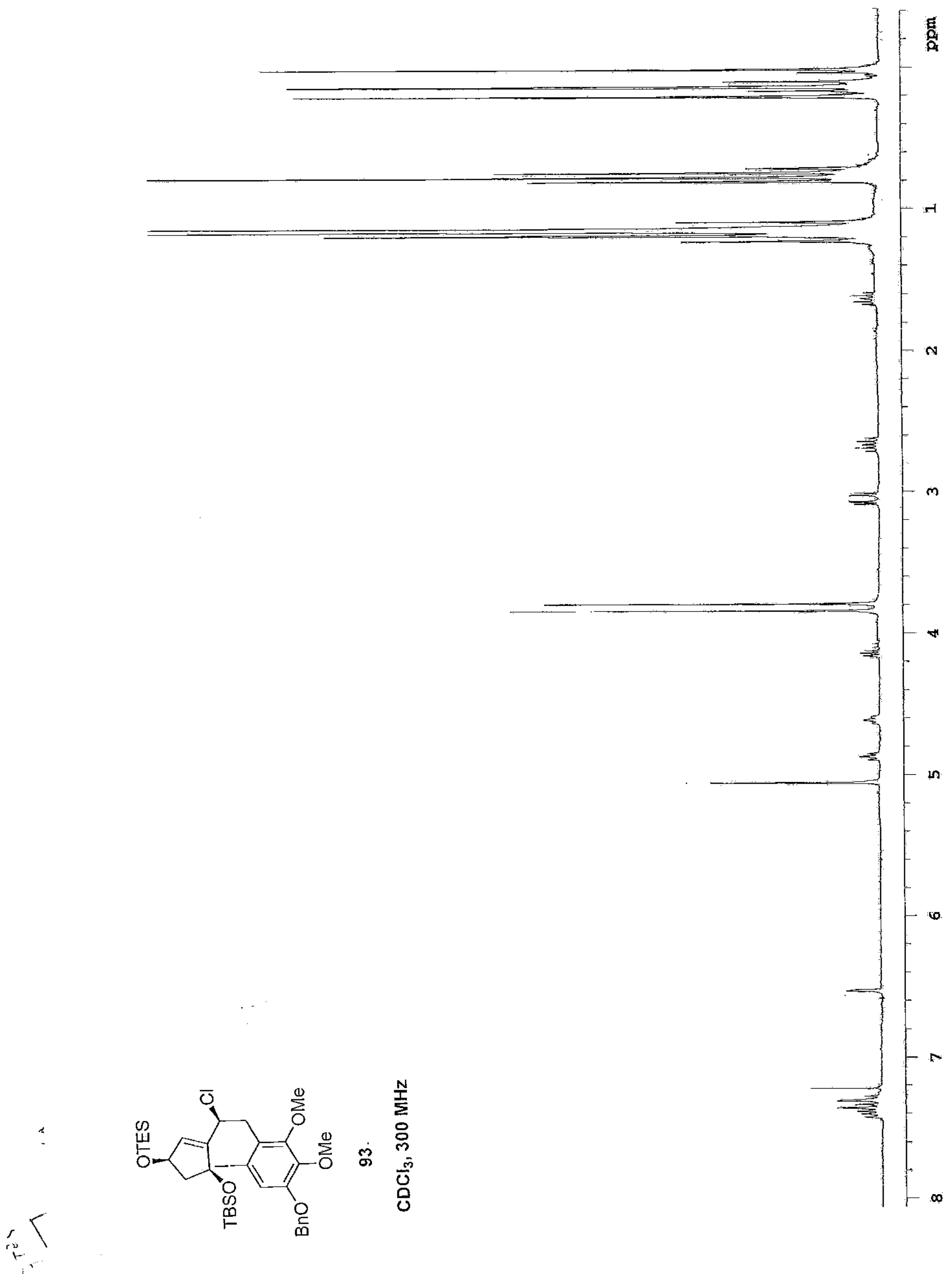

s 


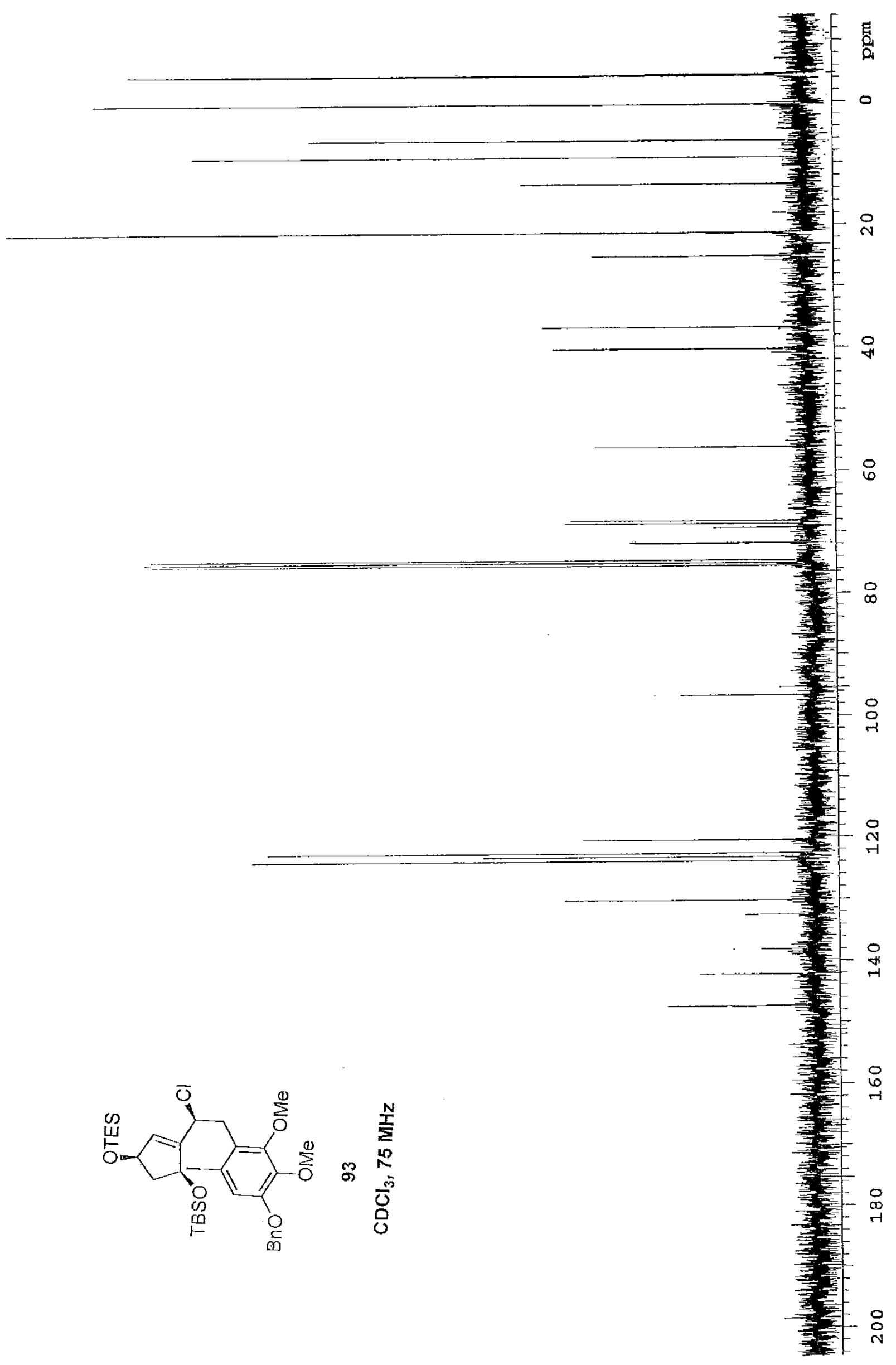




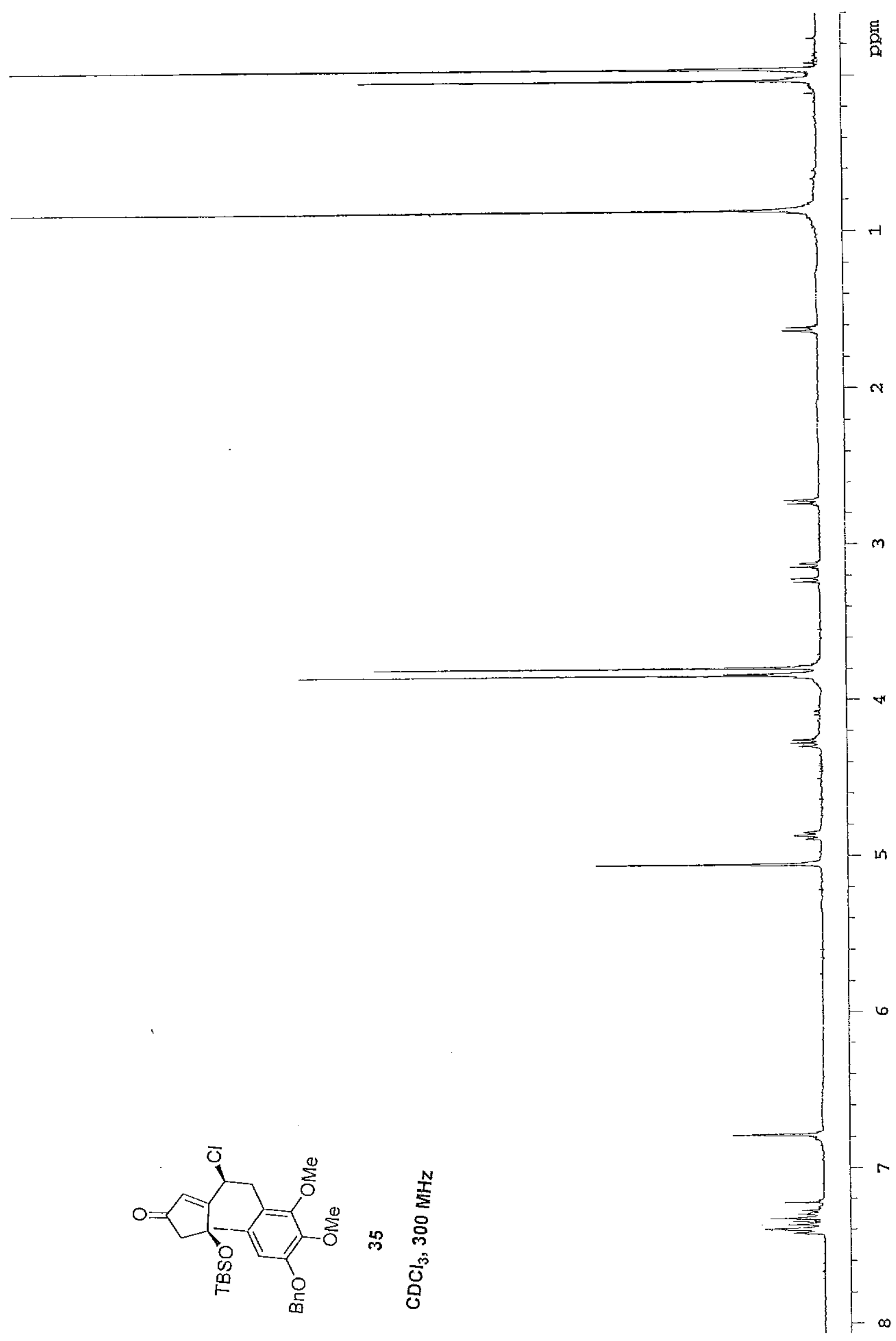




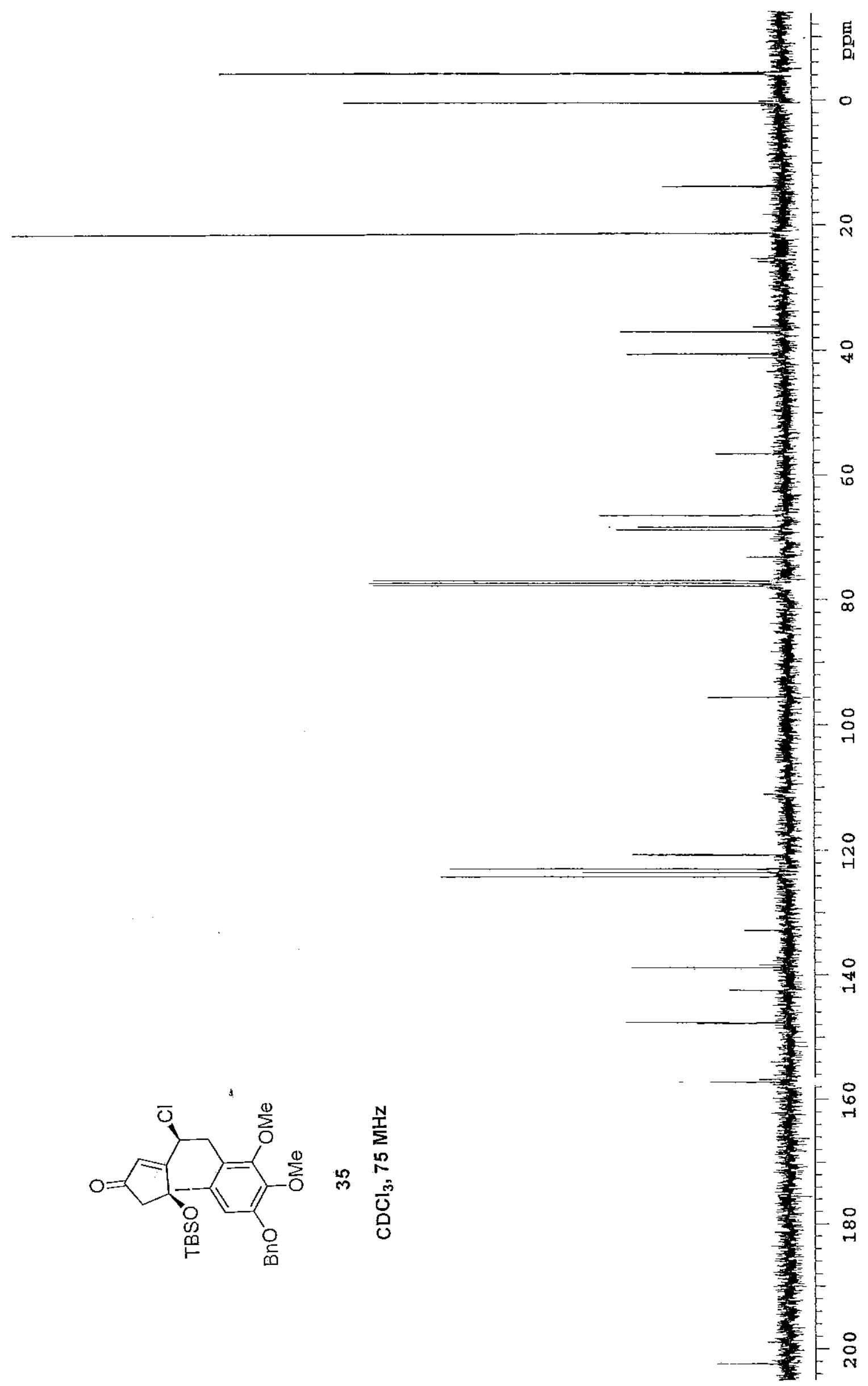




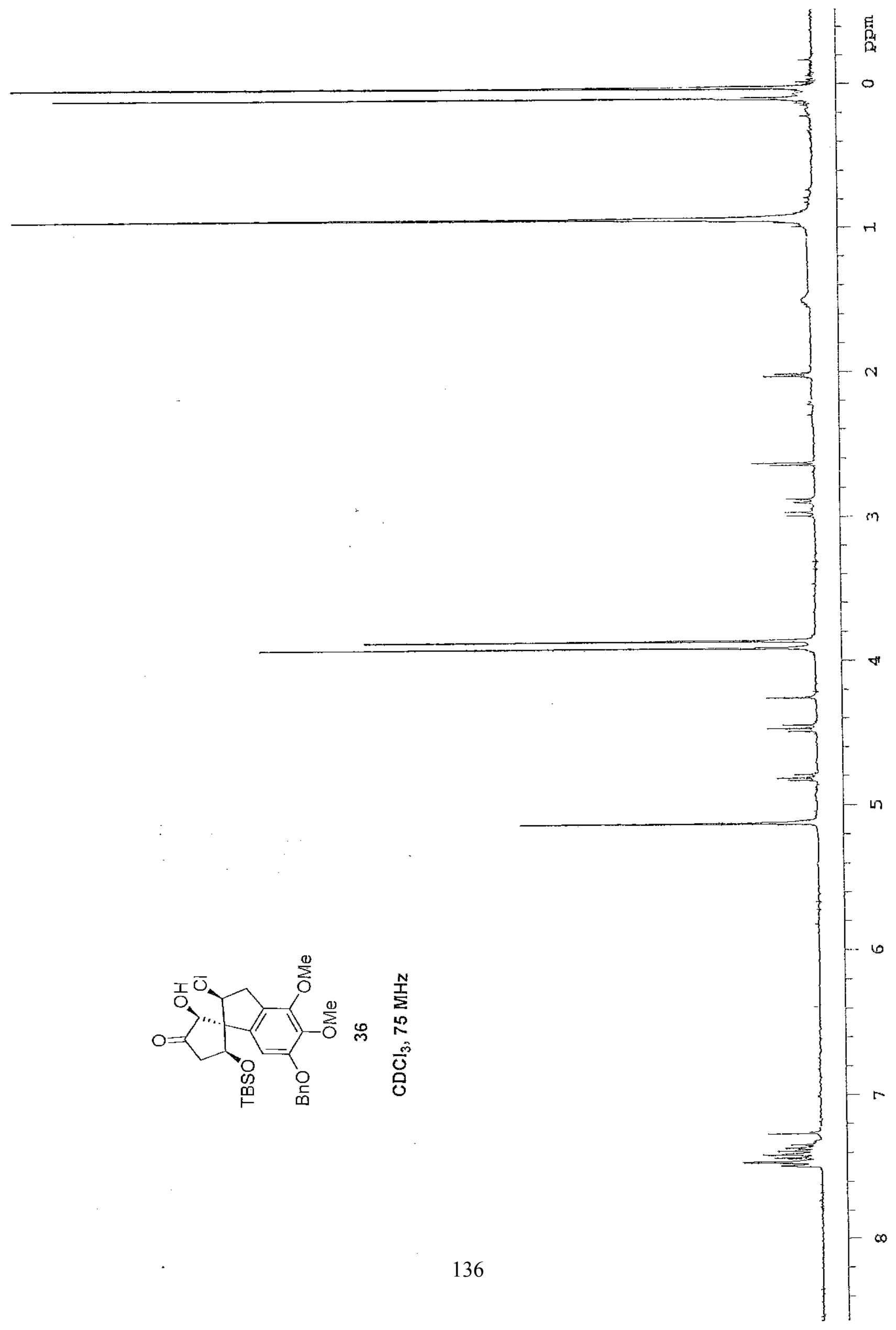




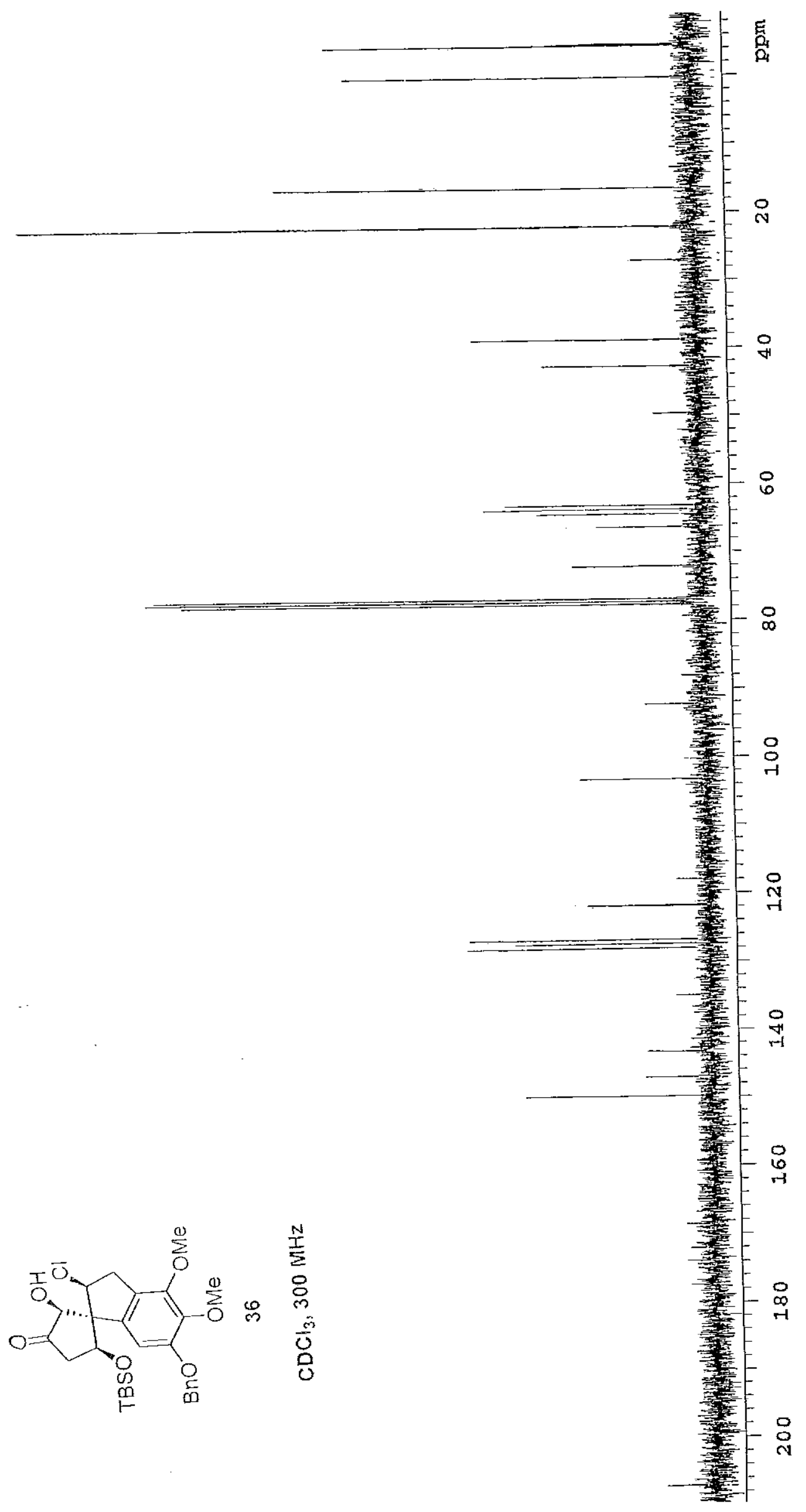




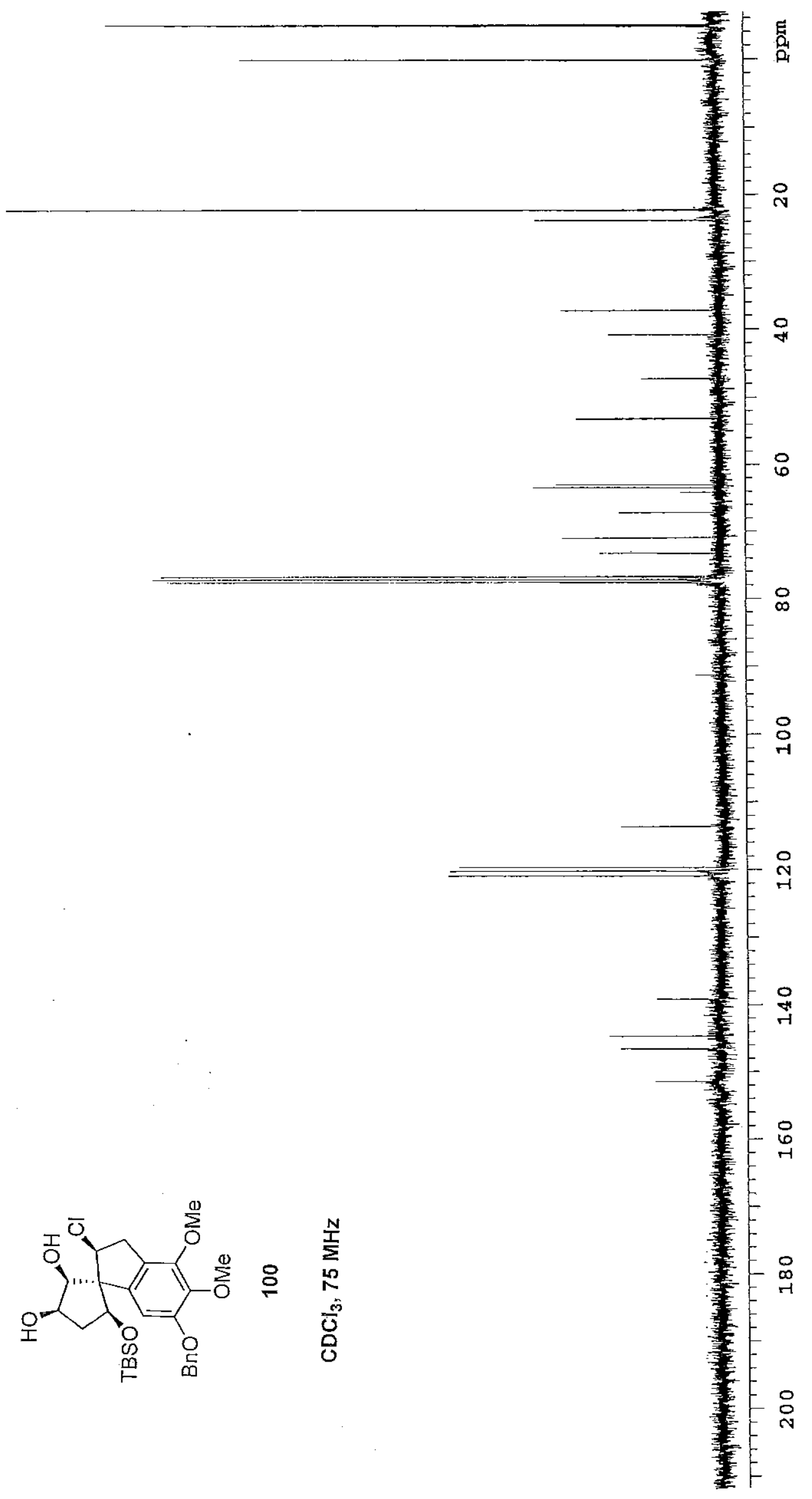




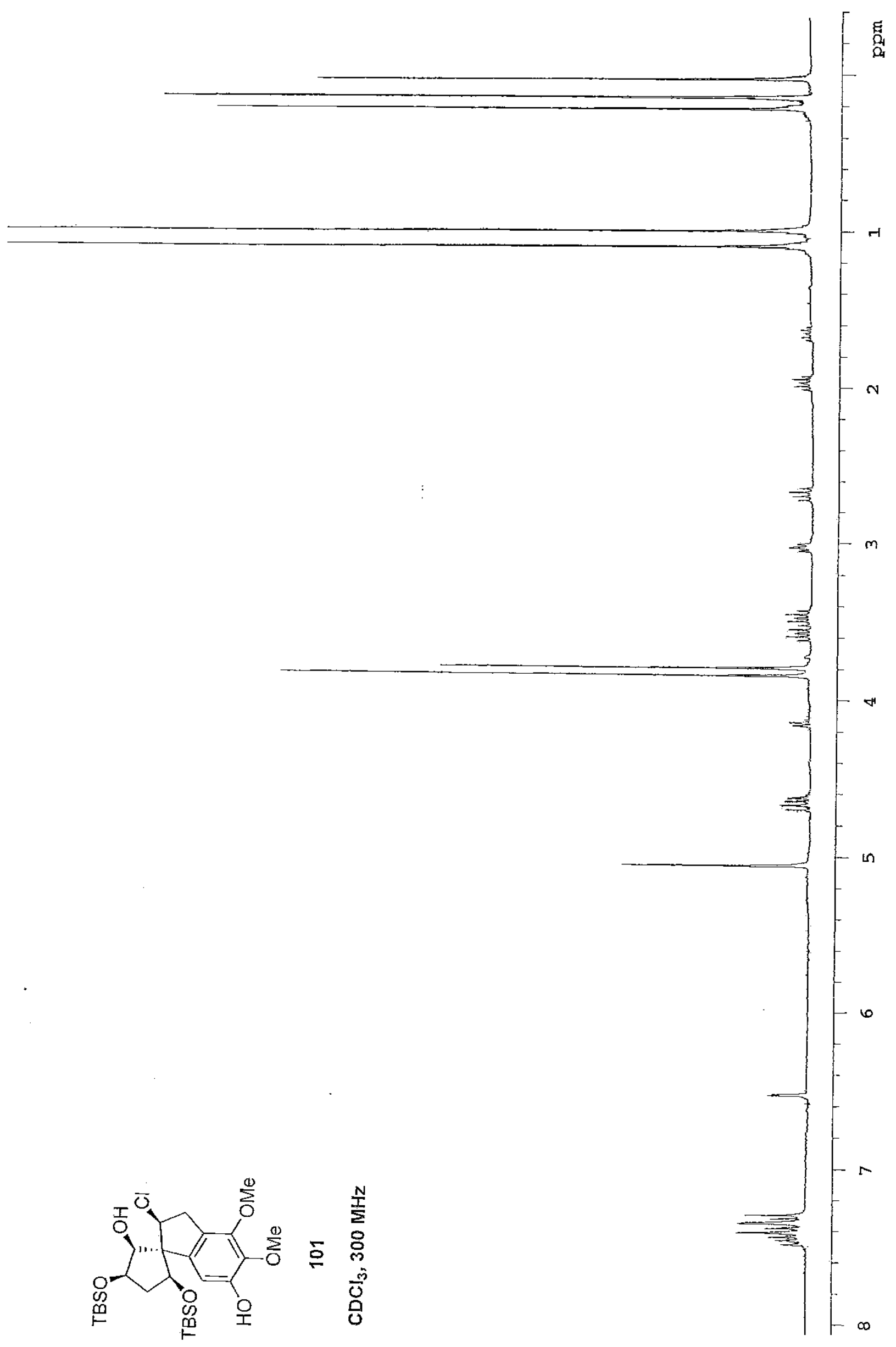




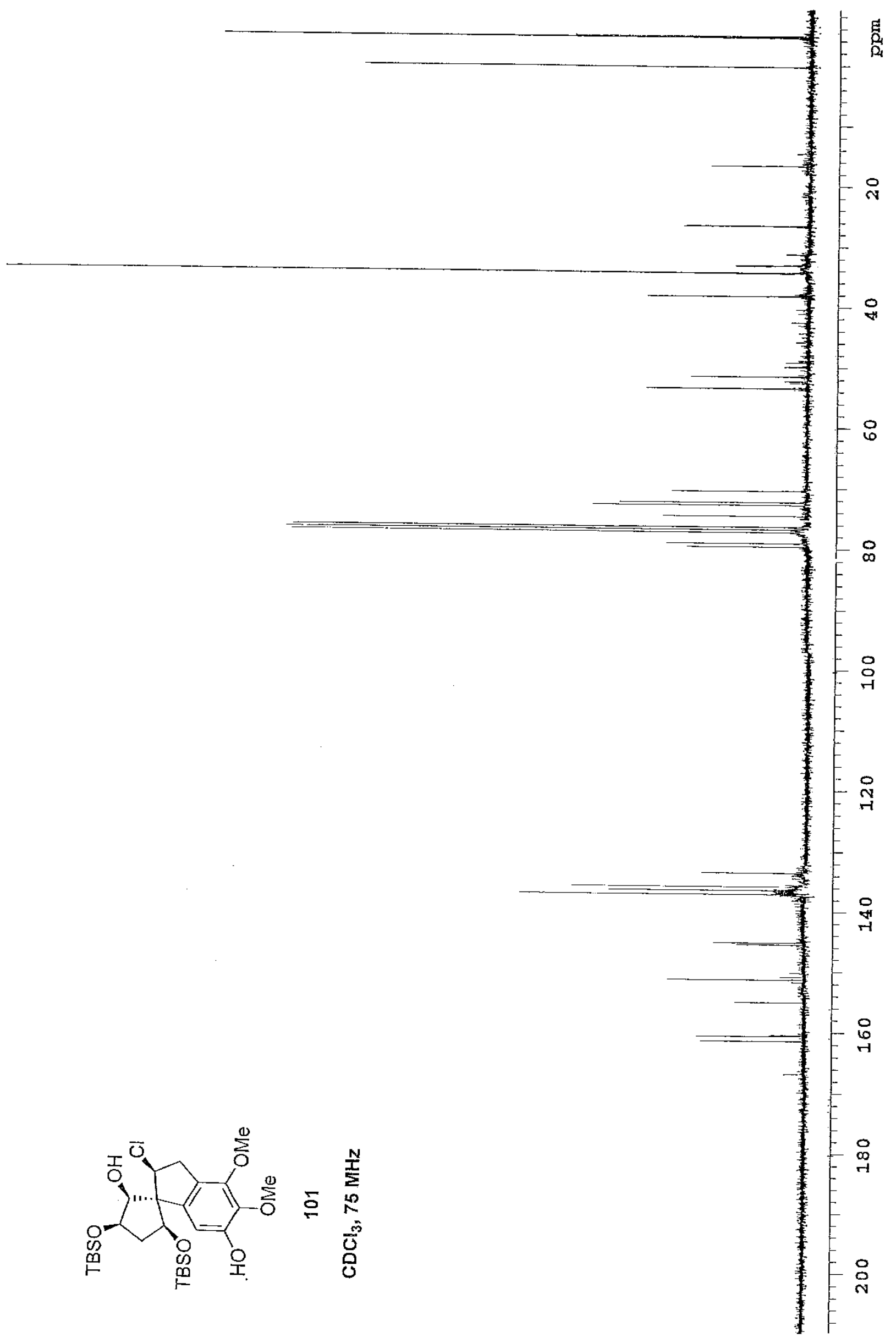




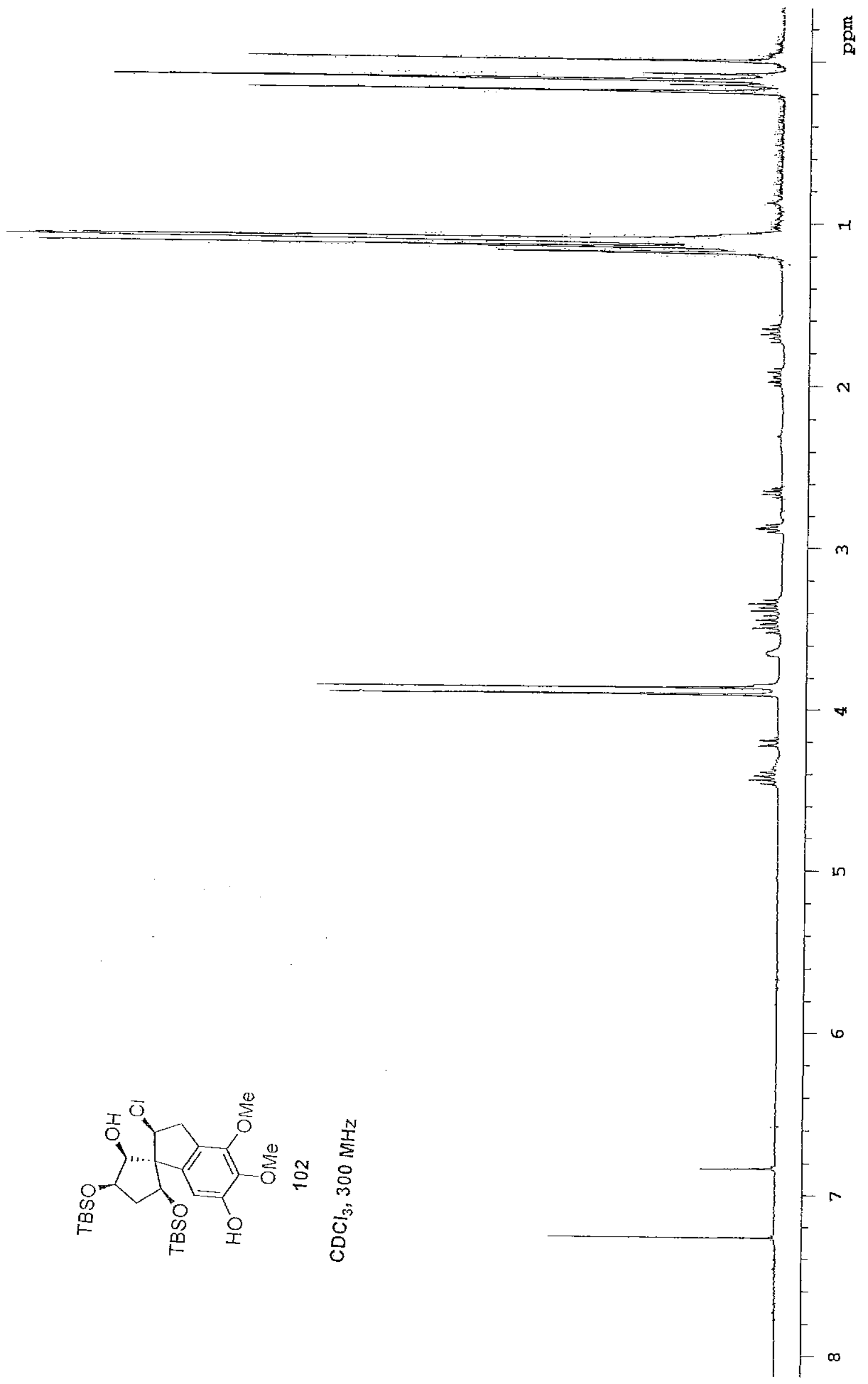




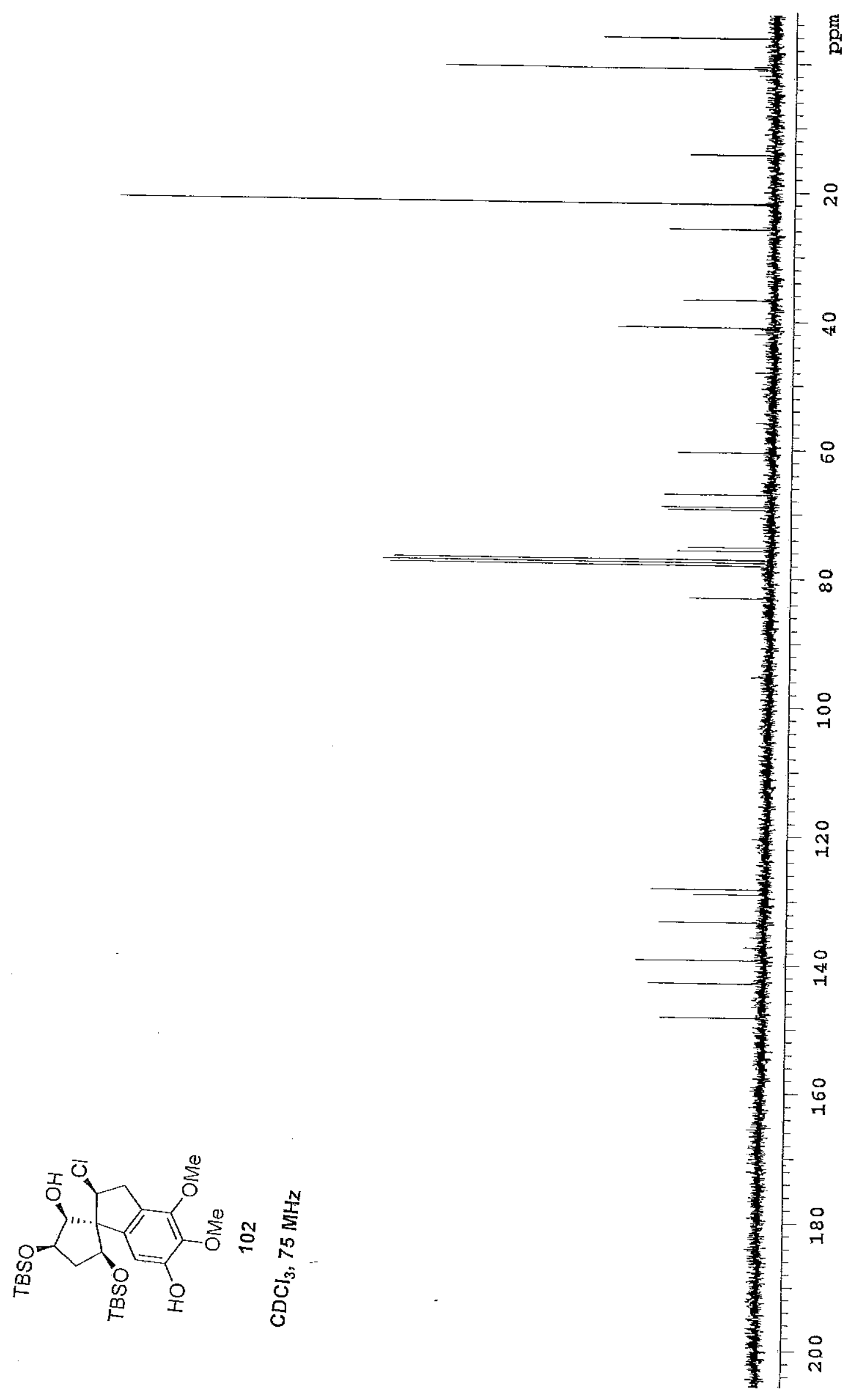




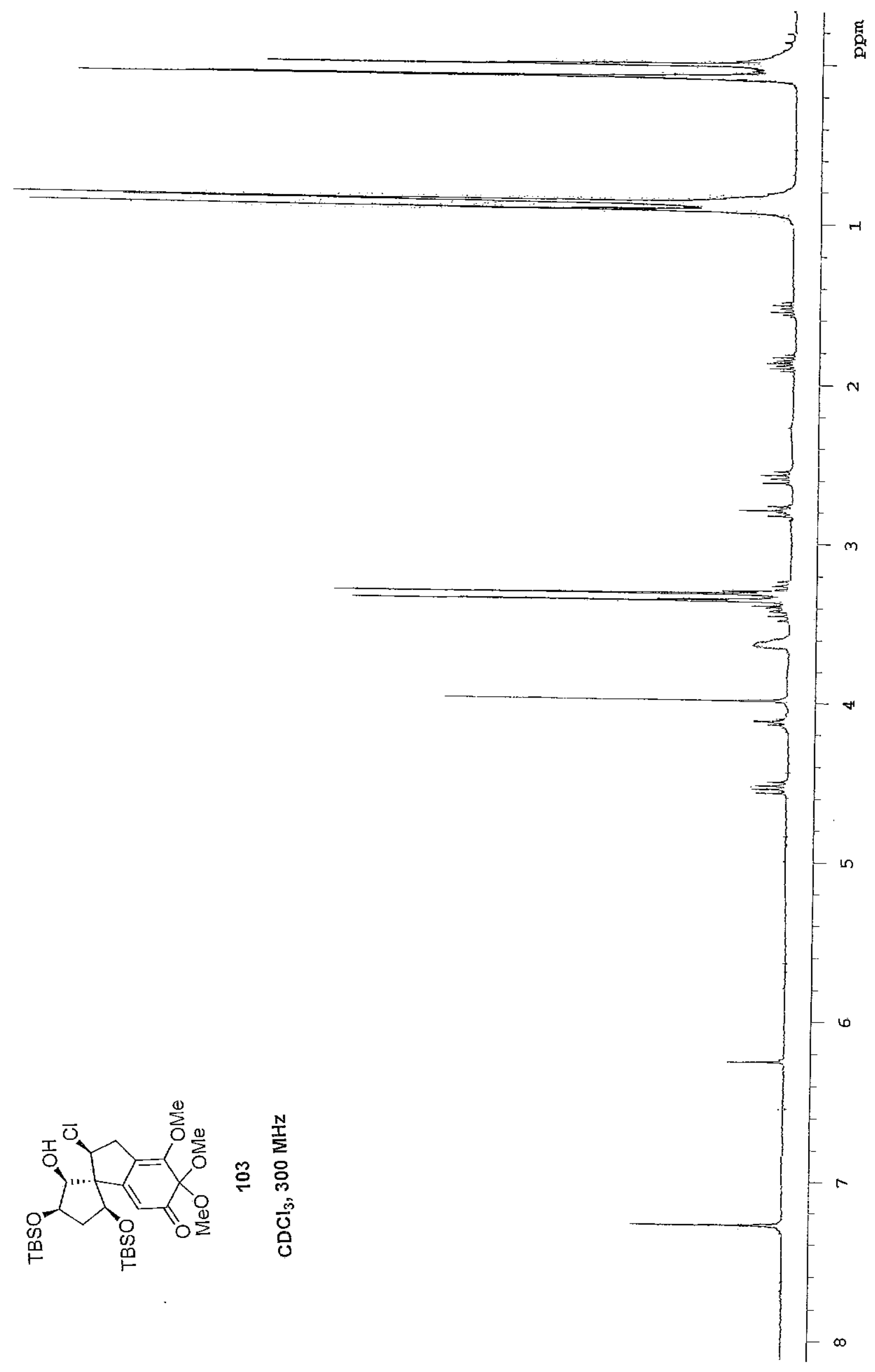




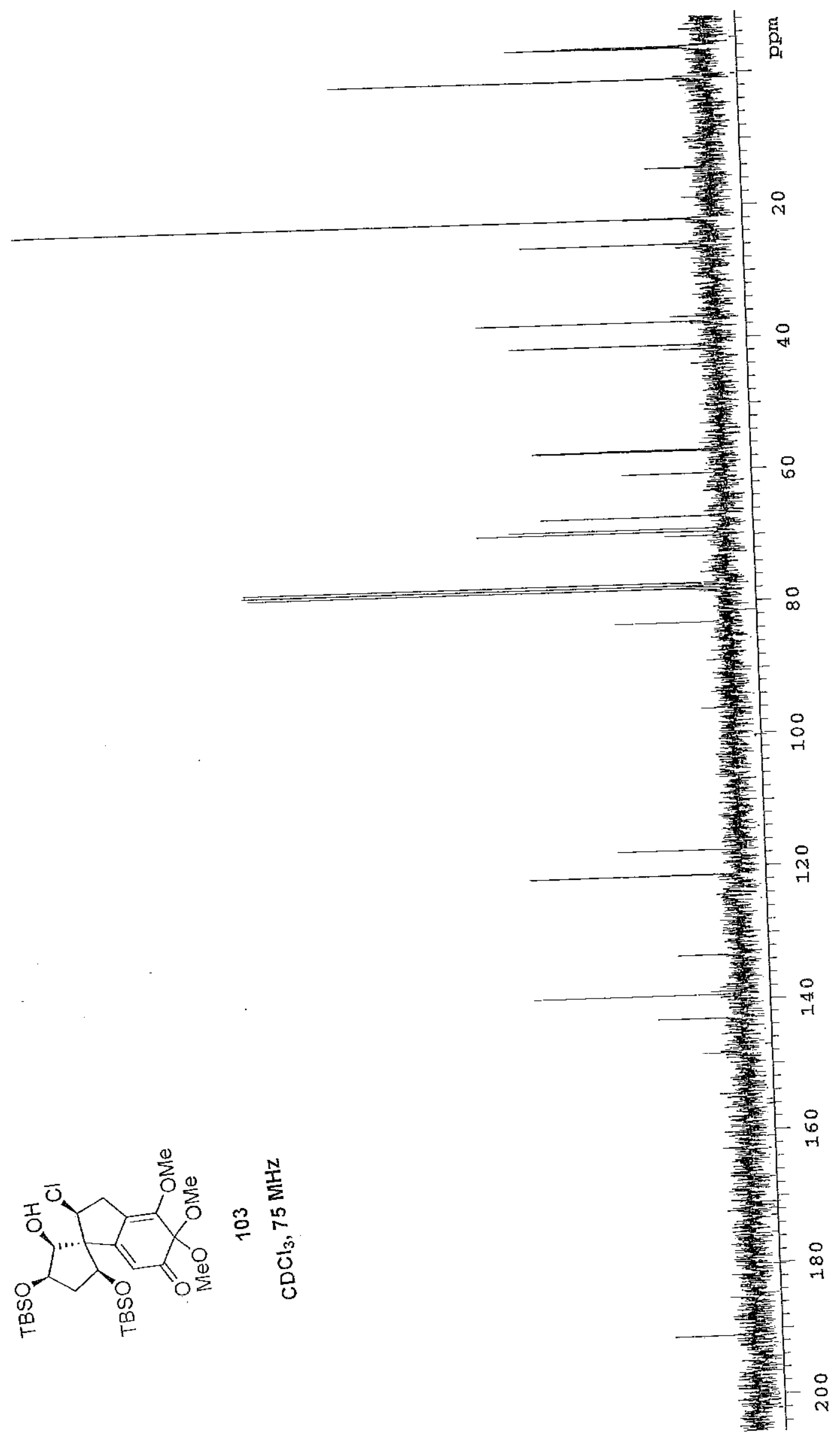




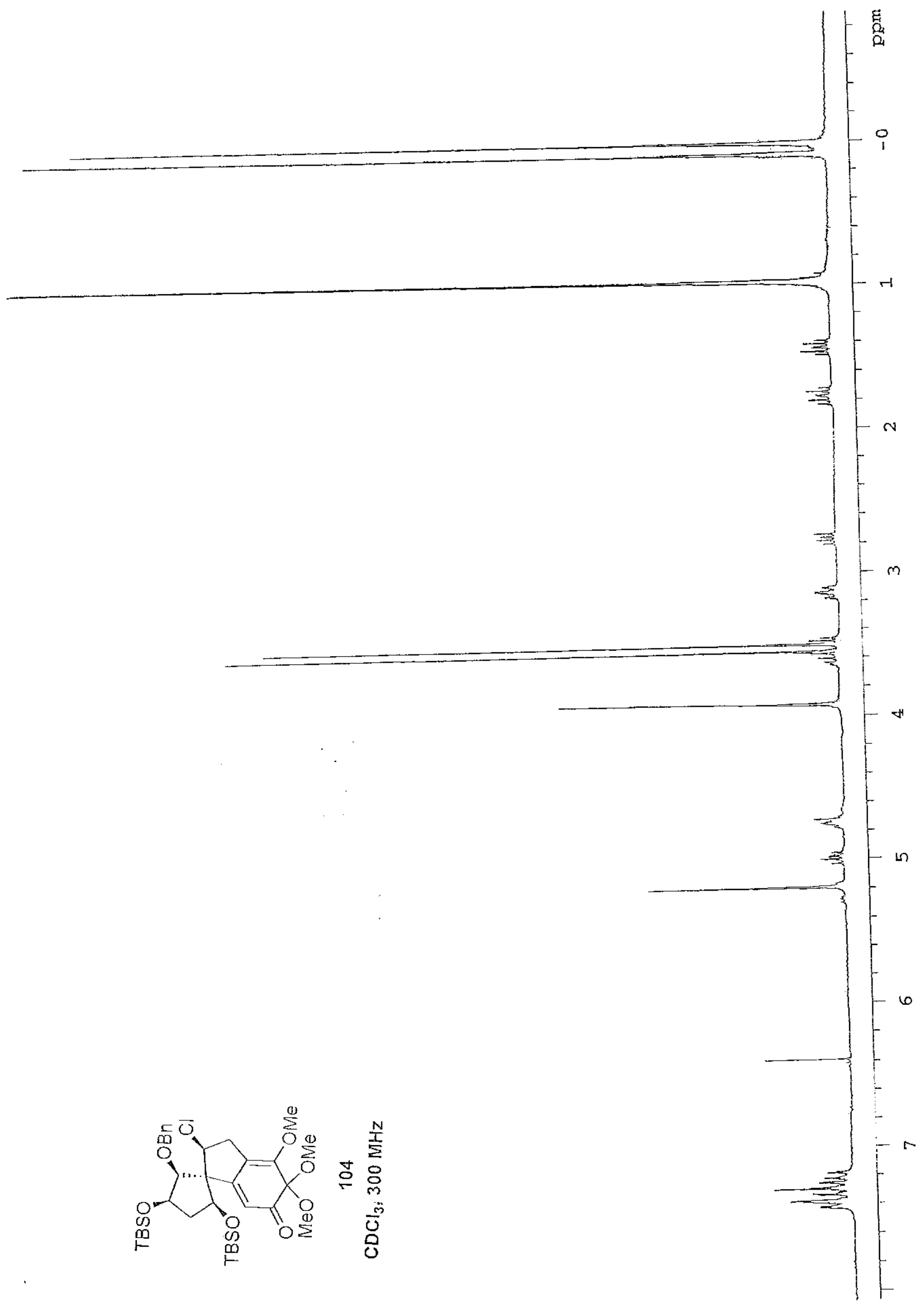




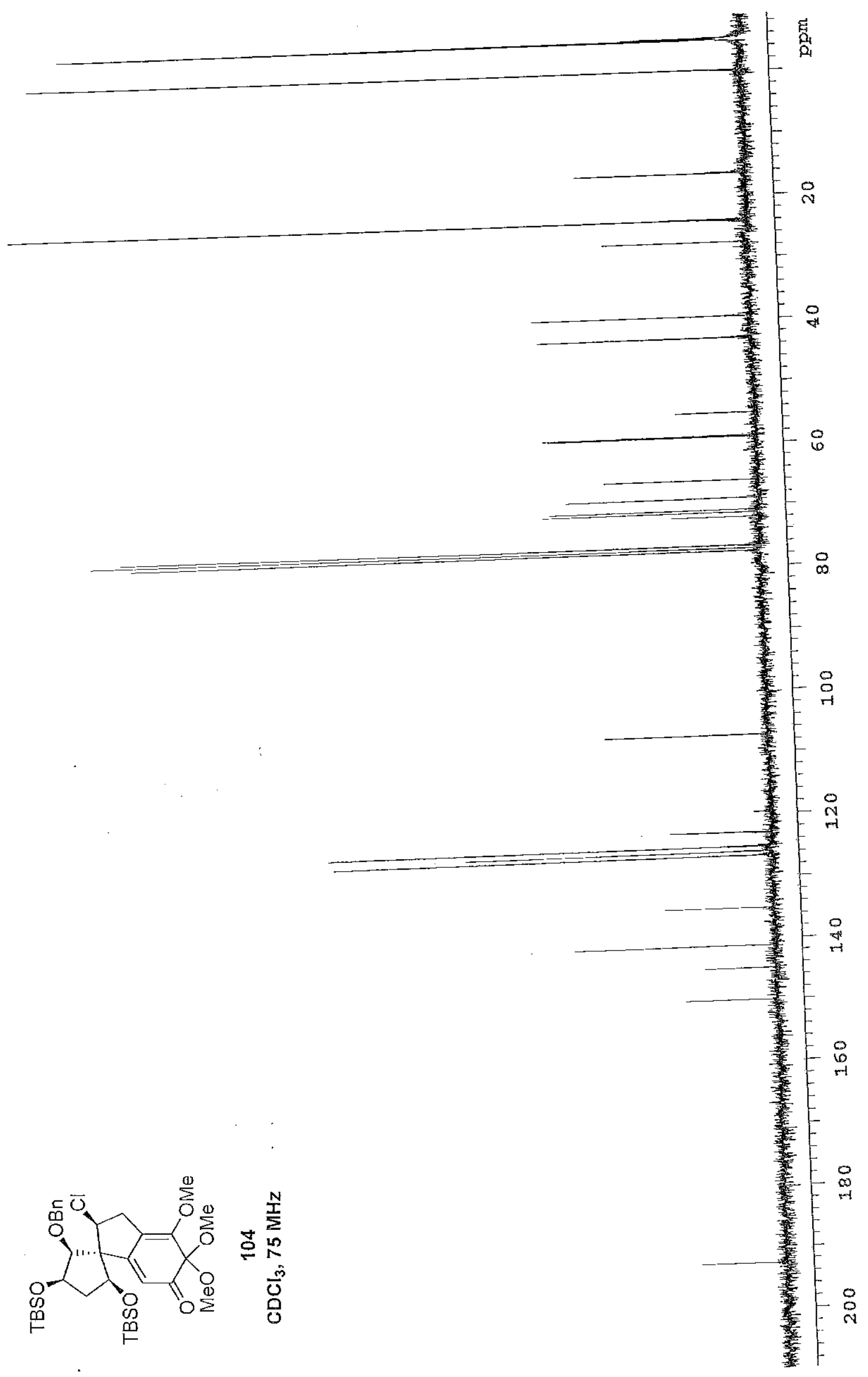




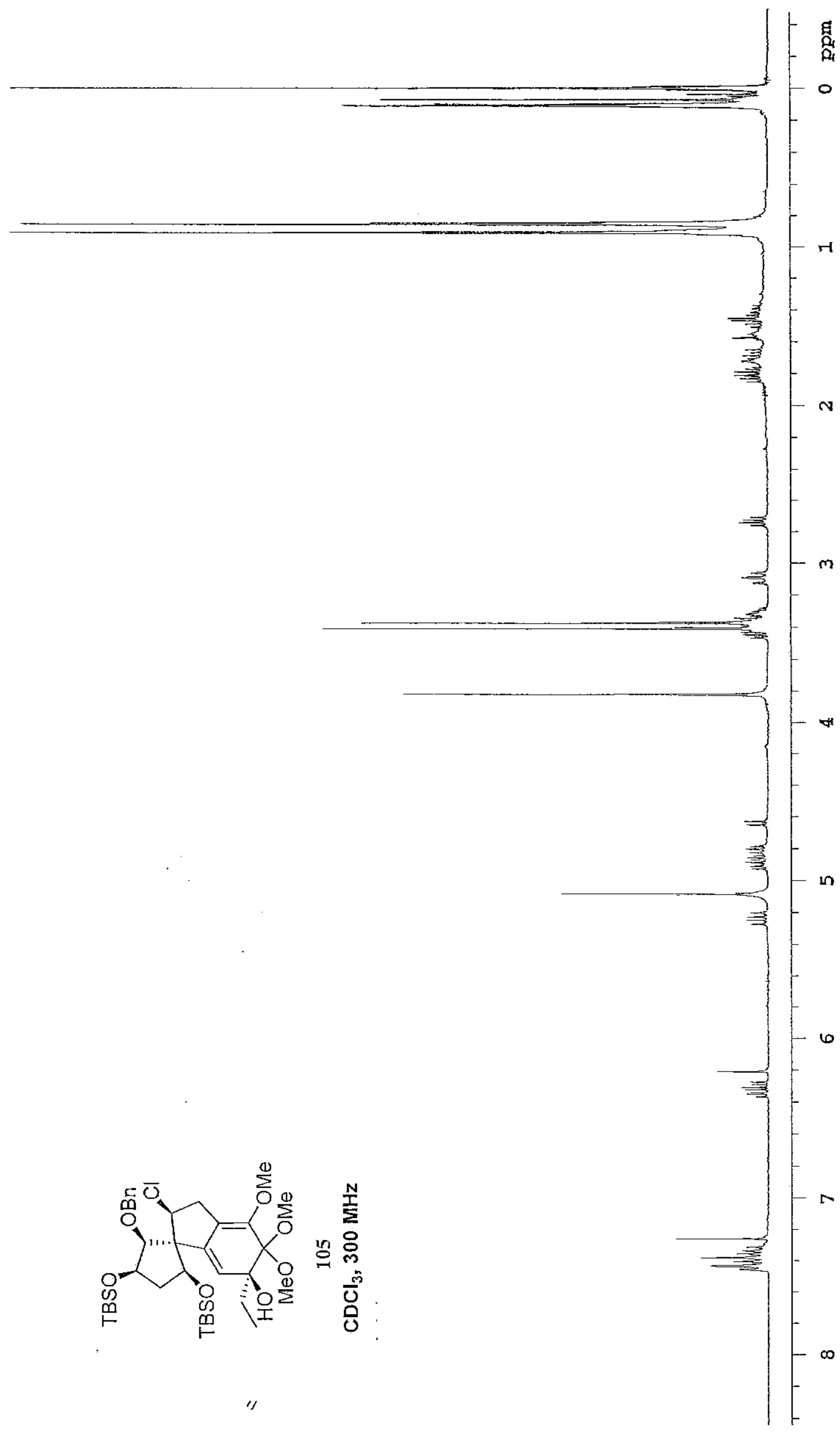




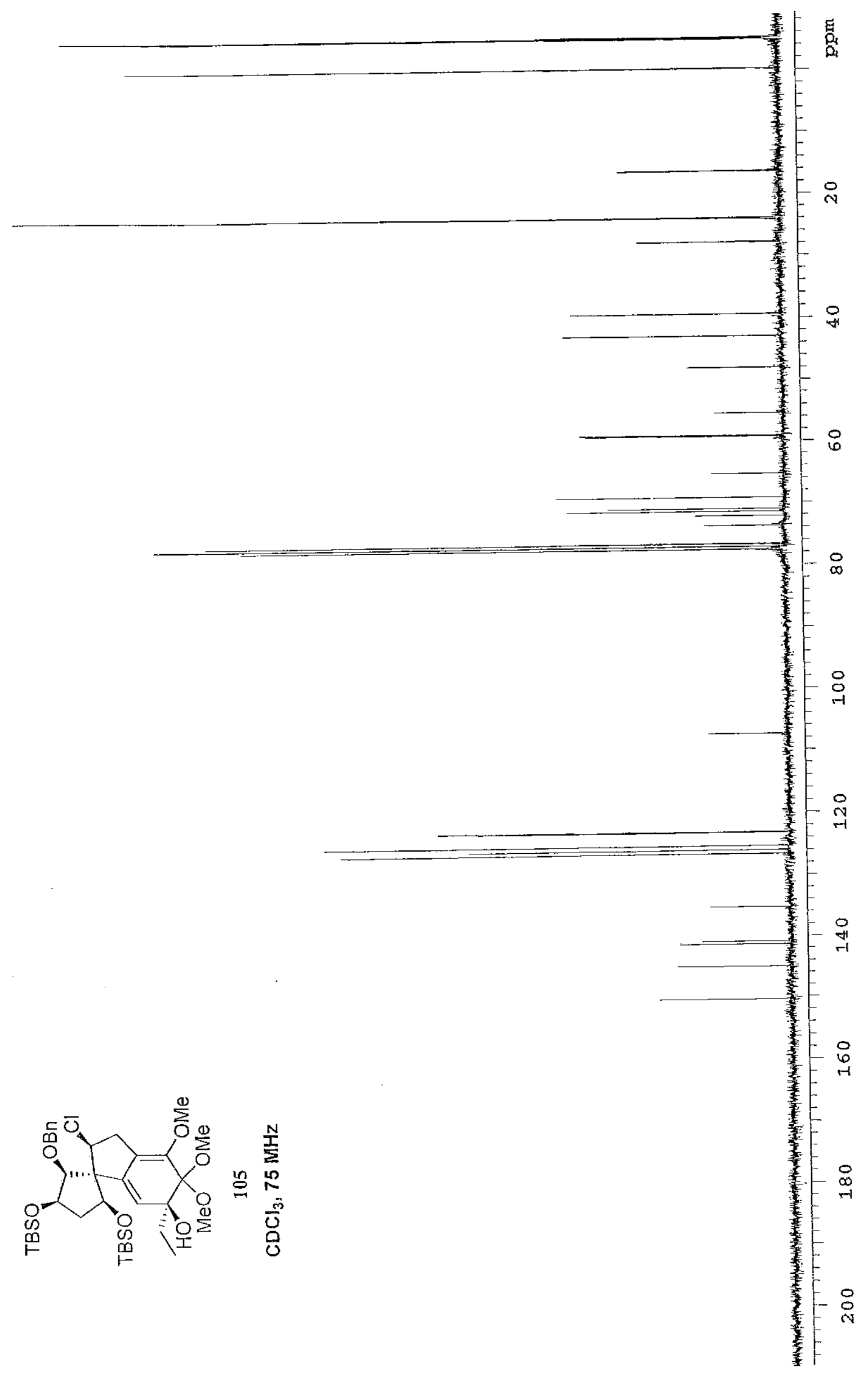




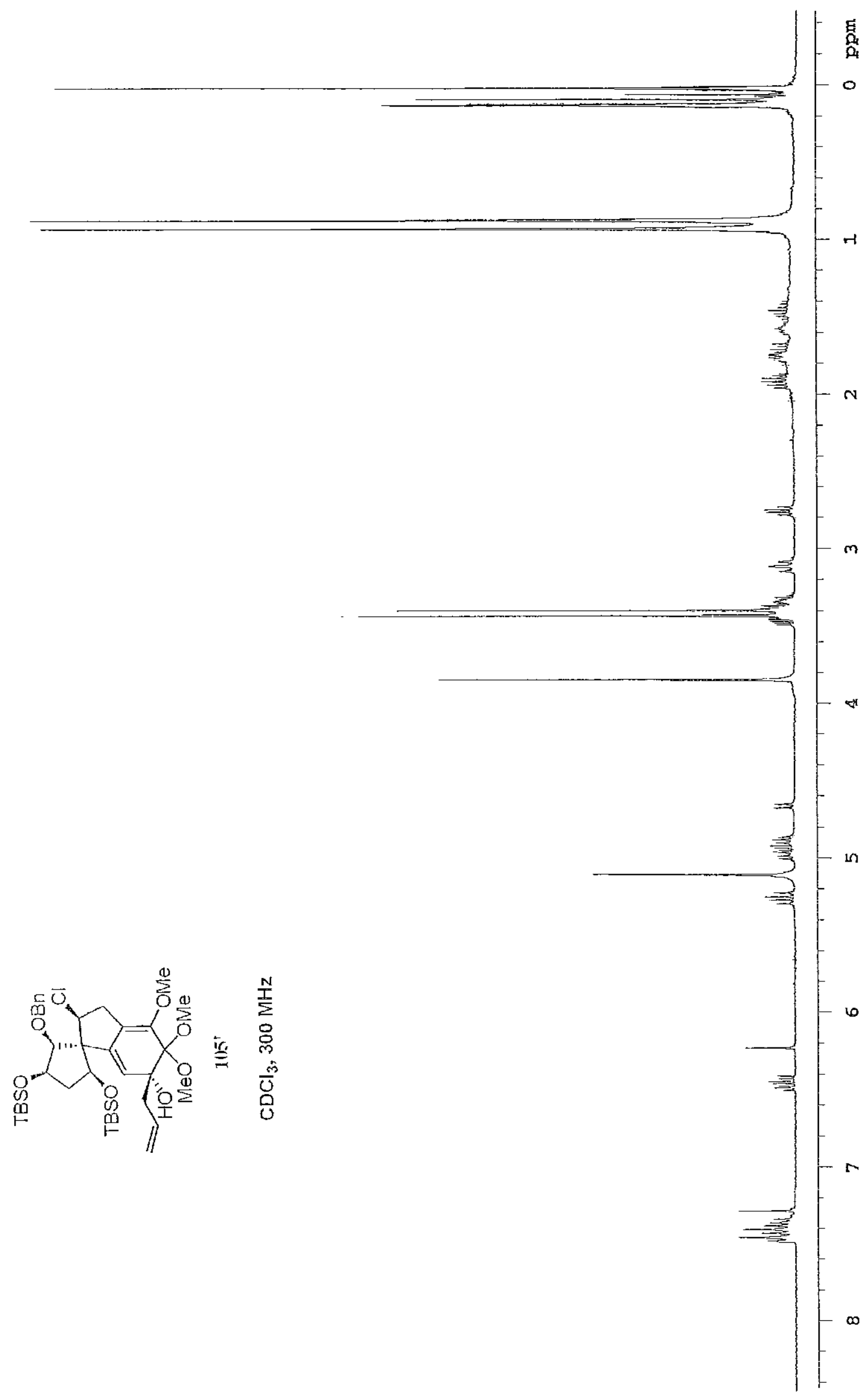




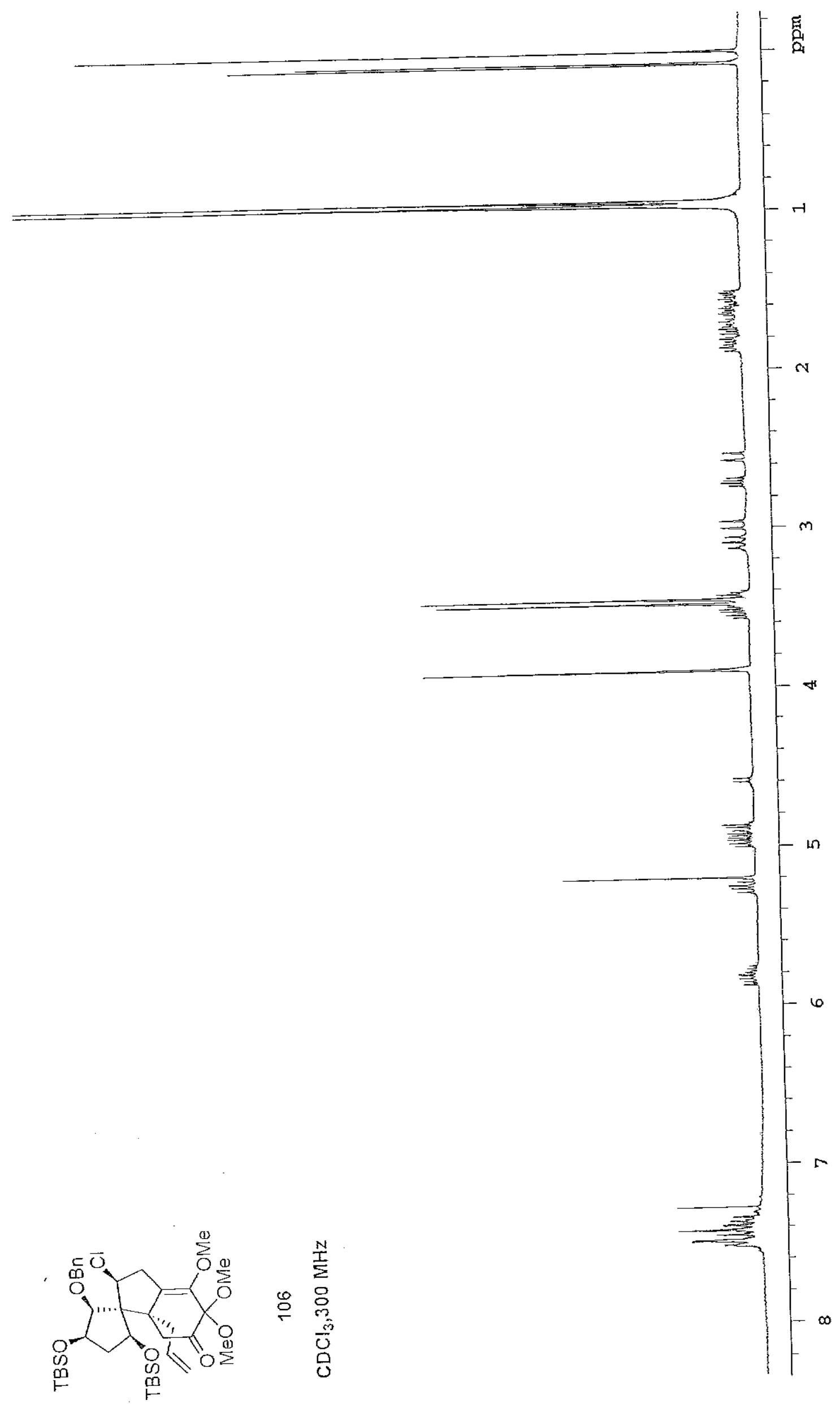




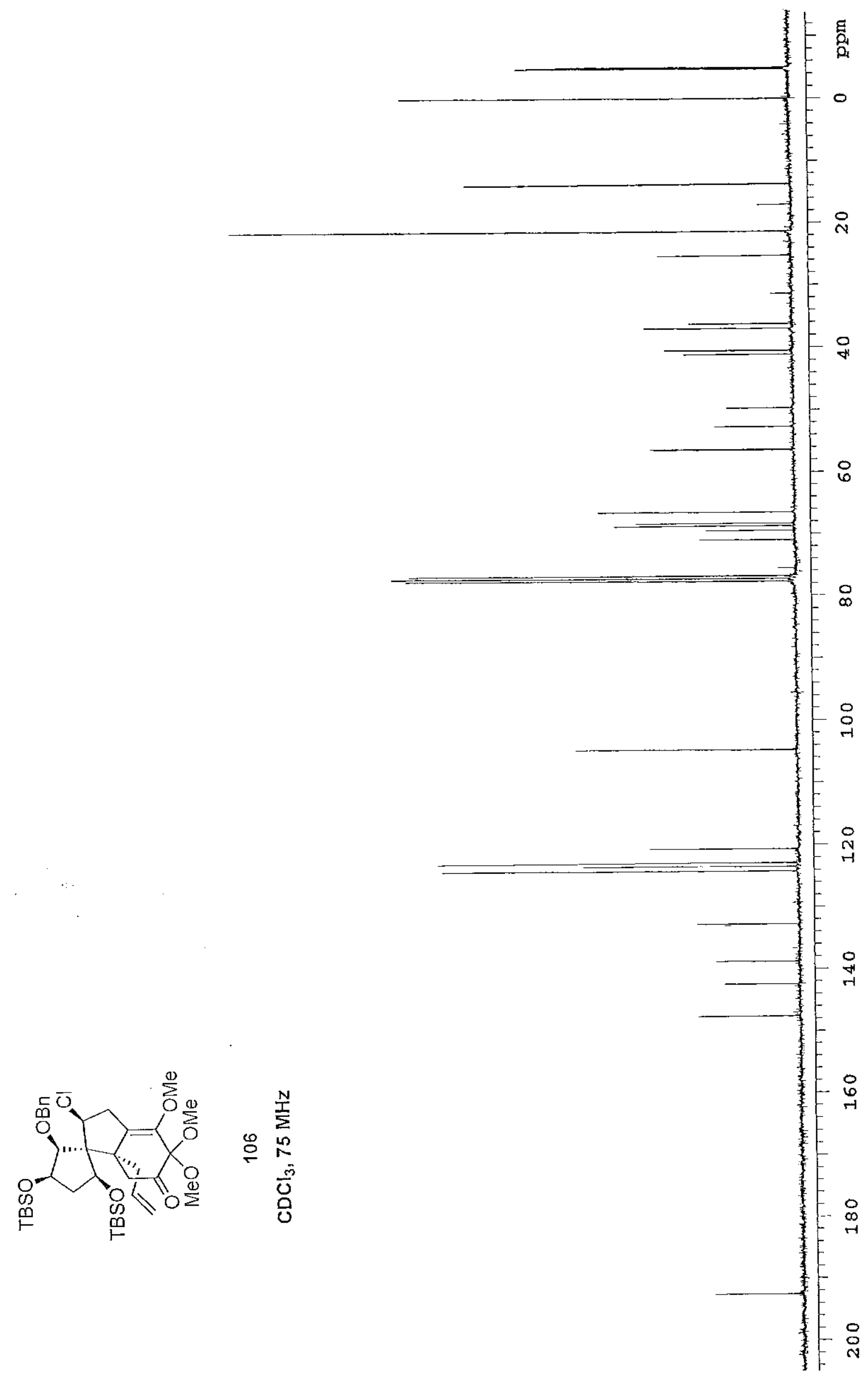




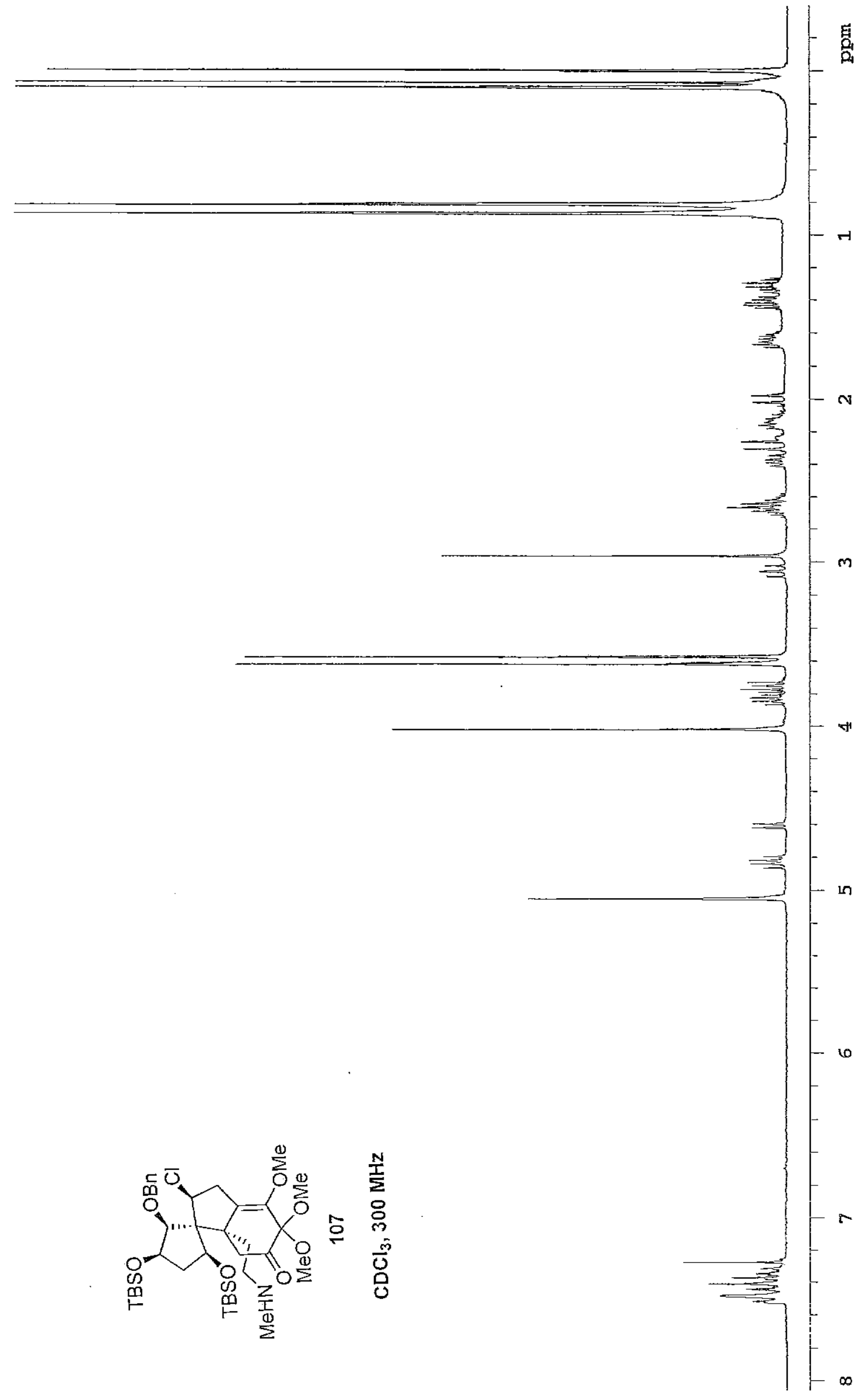




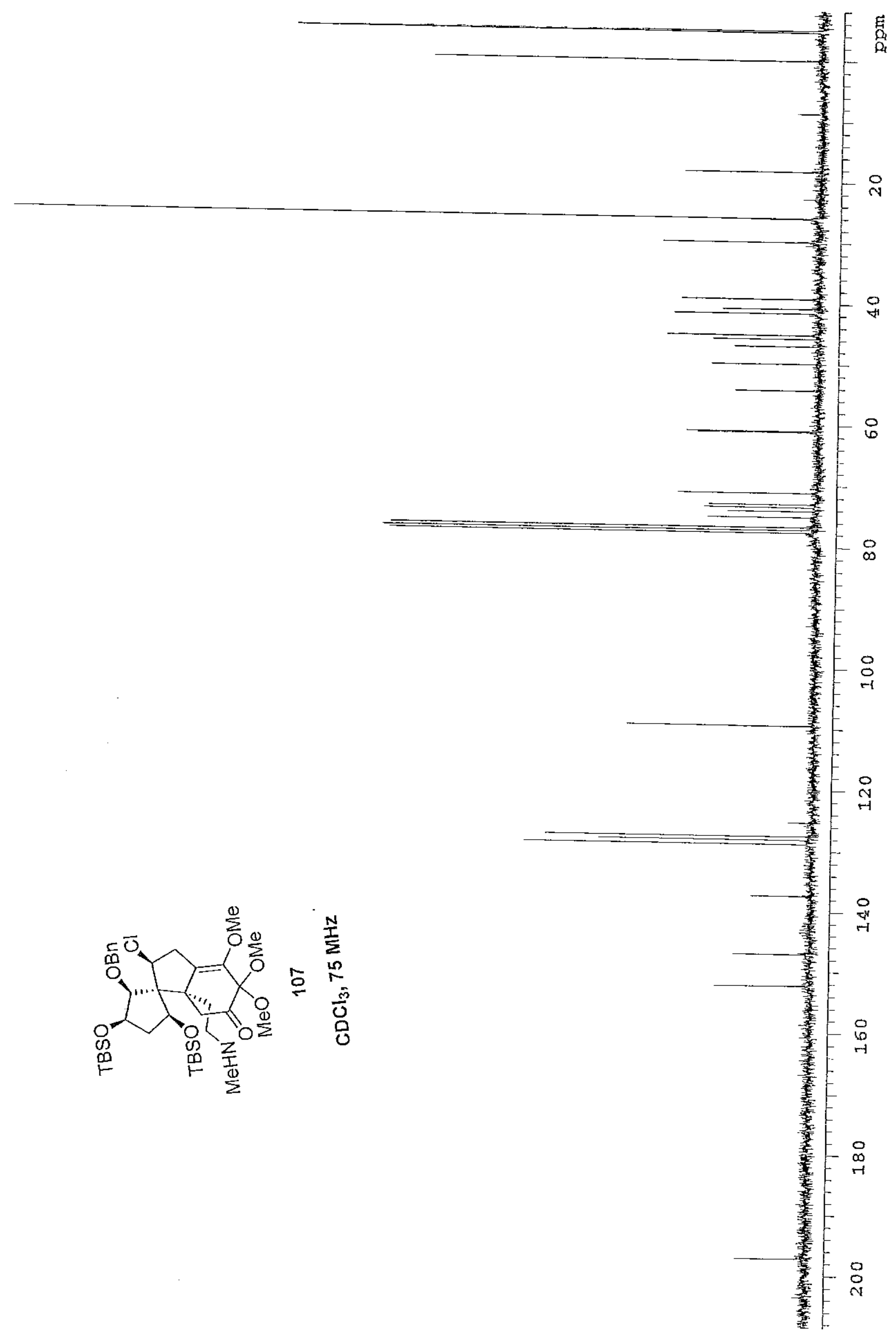




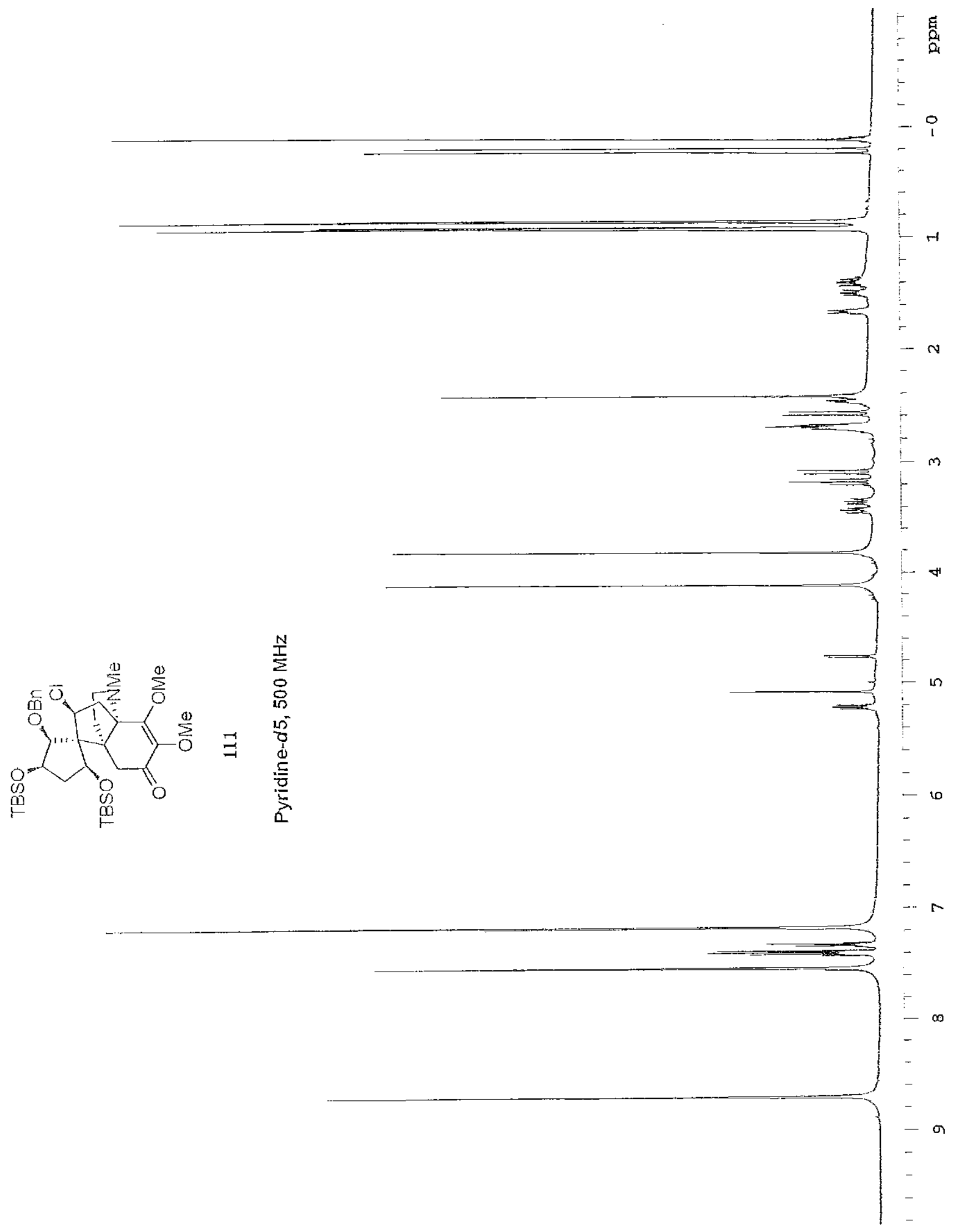




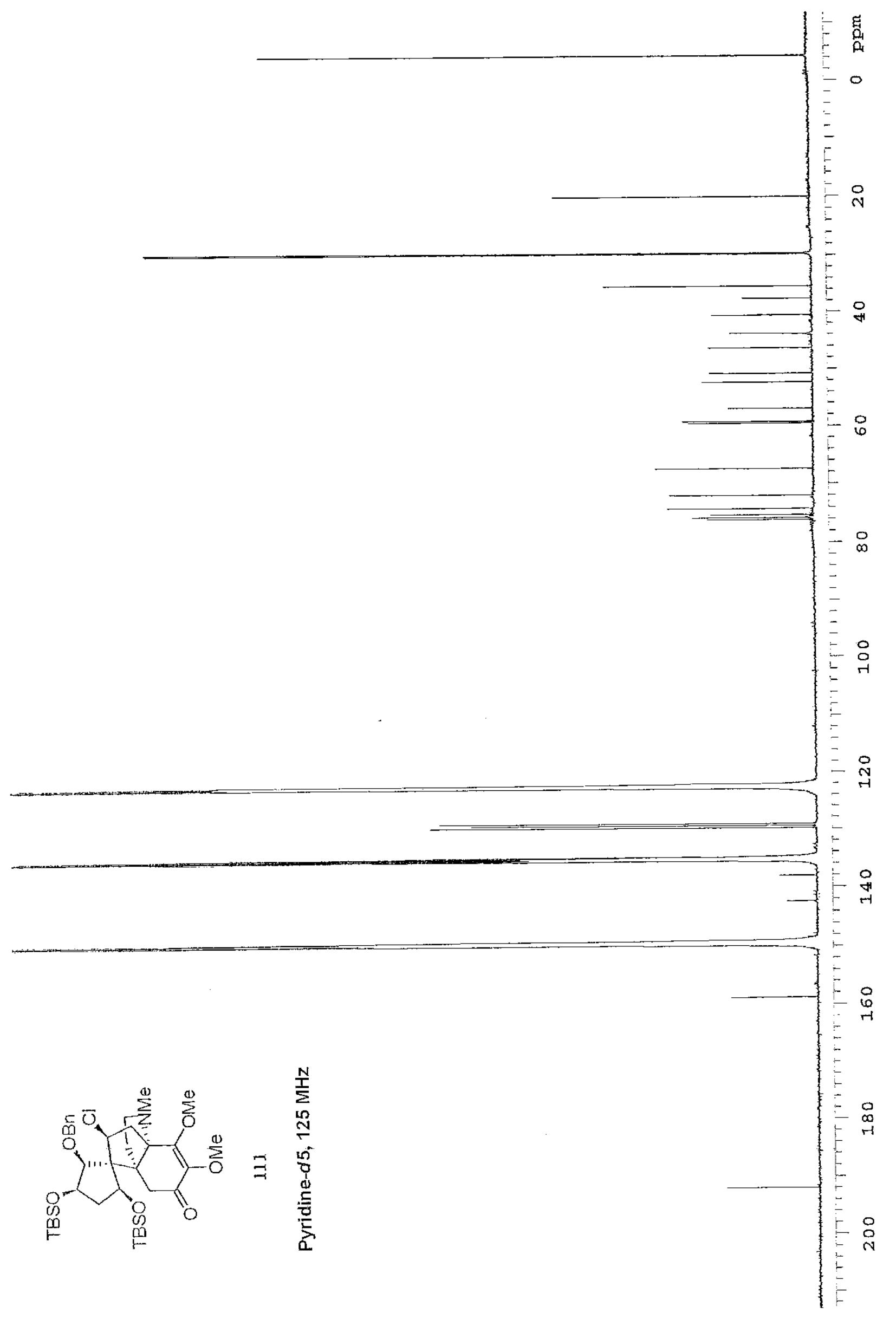




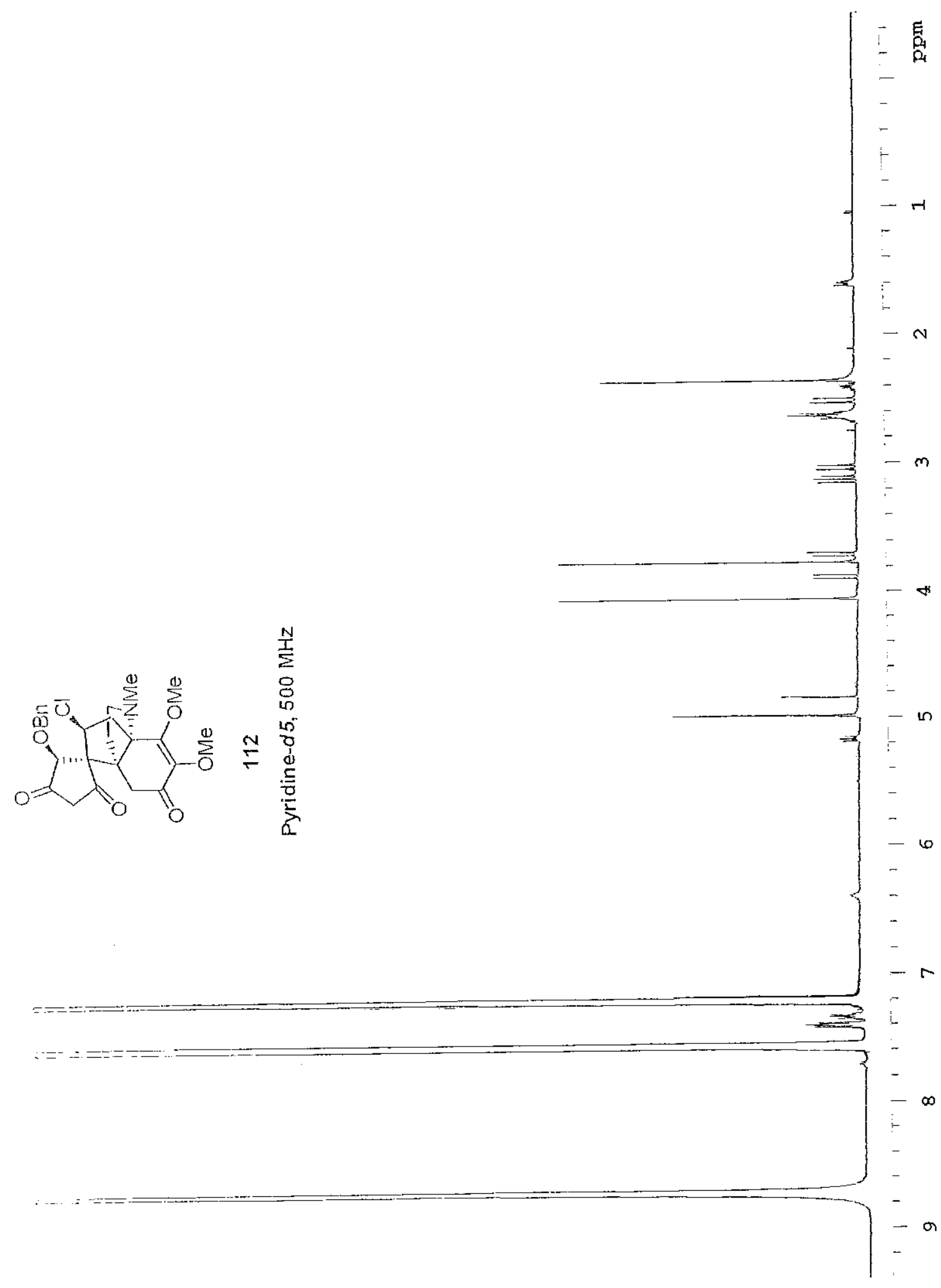




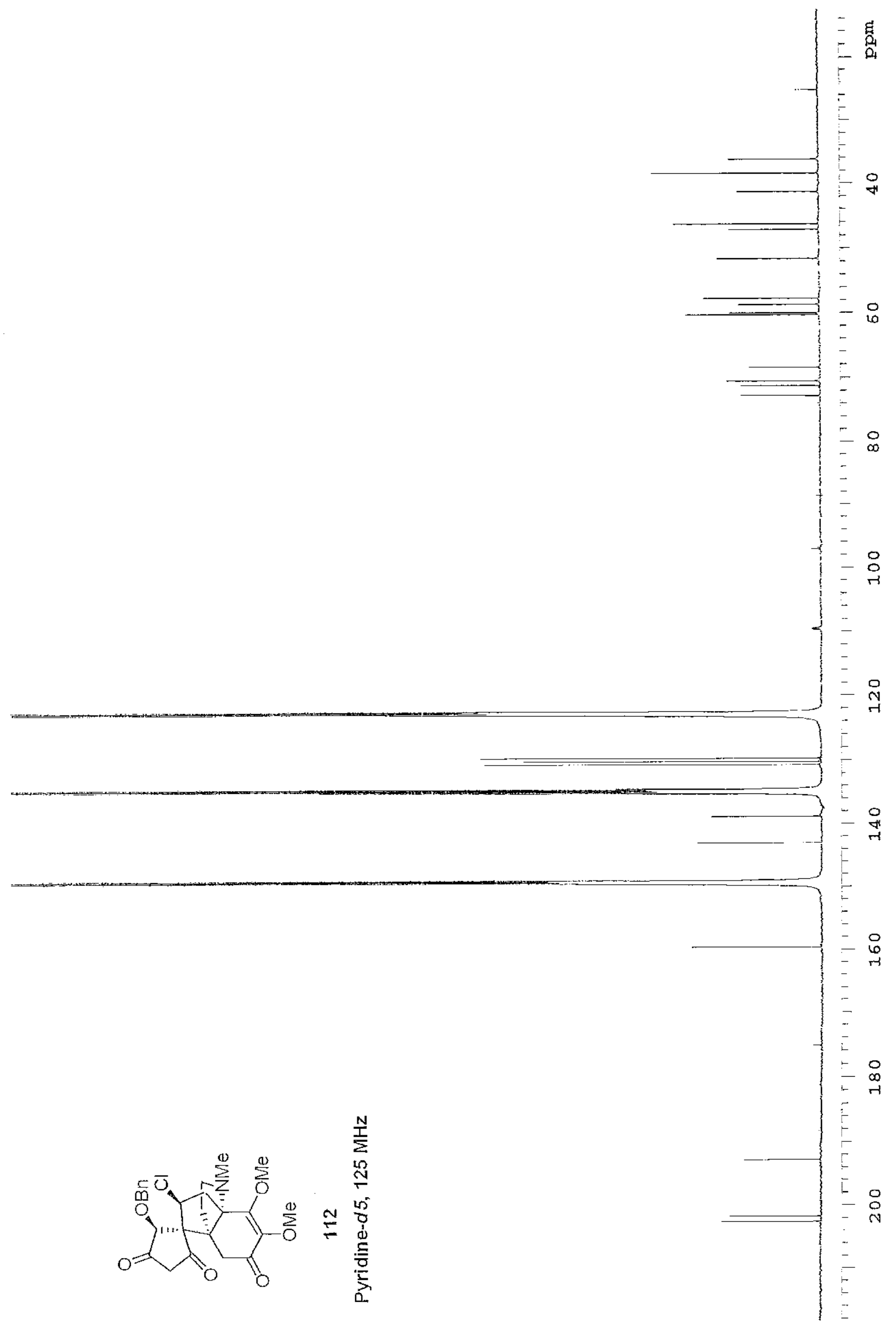




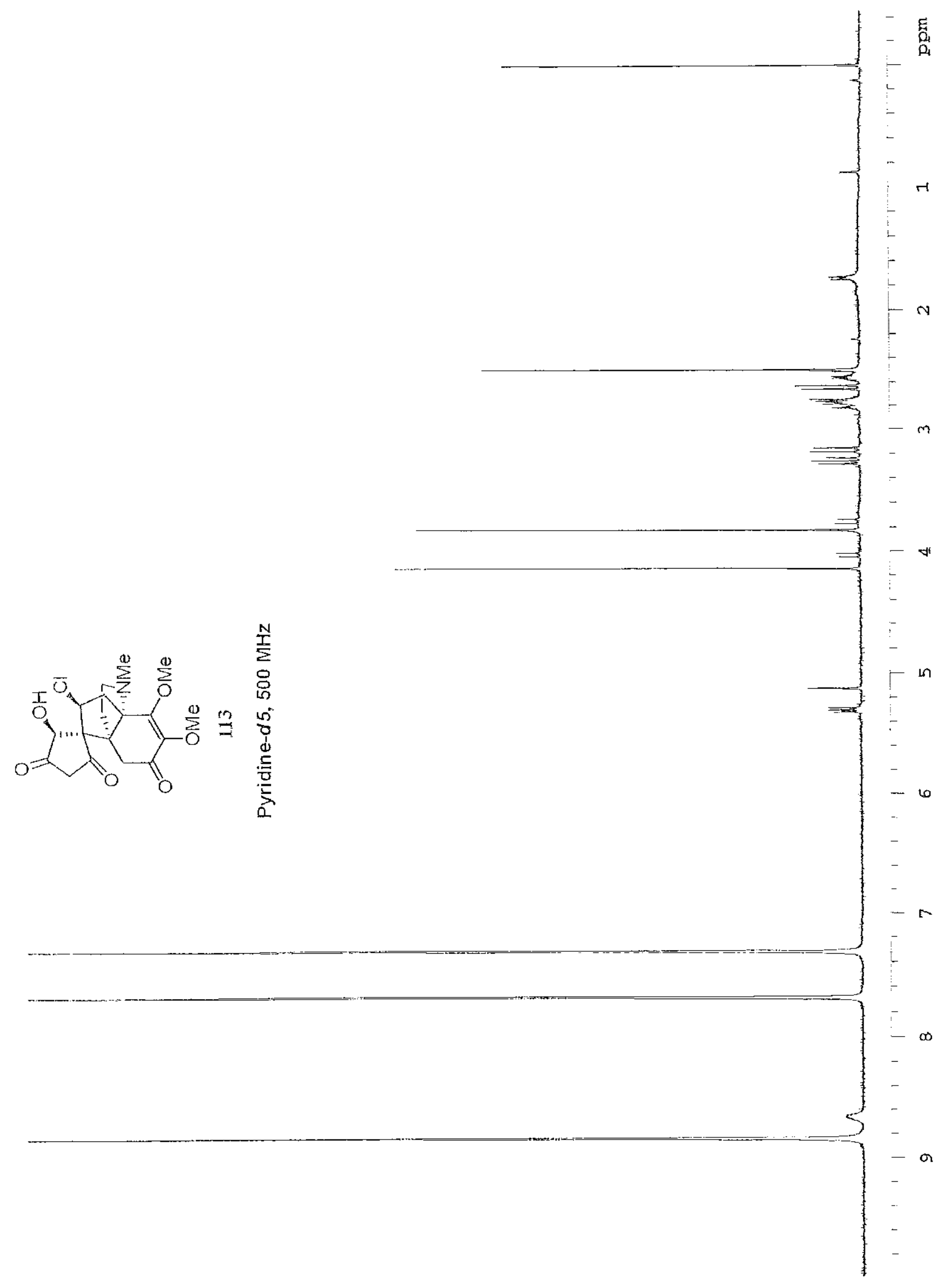




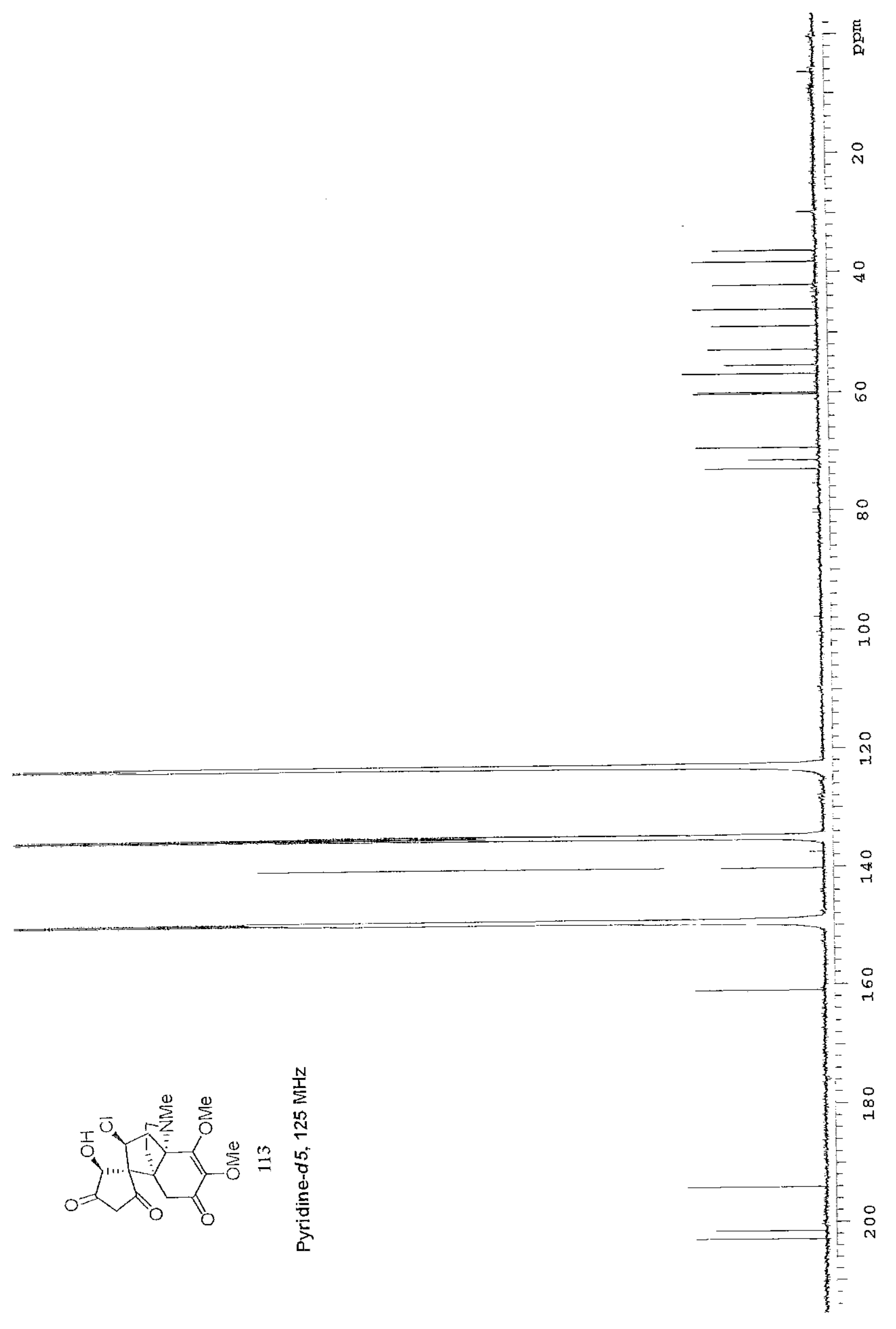




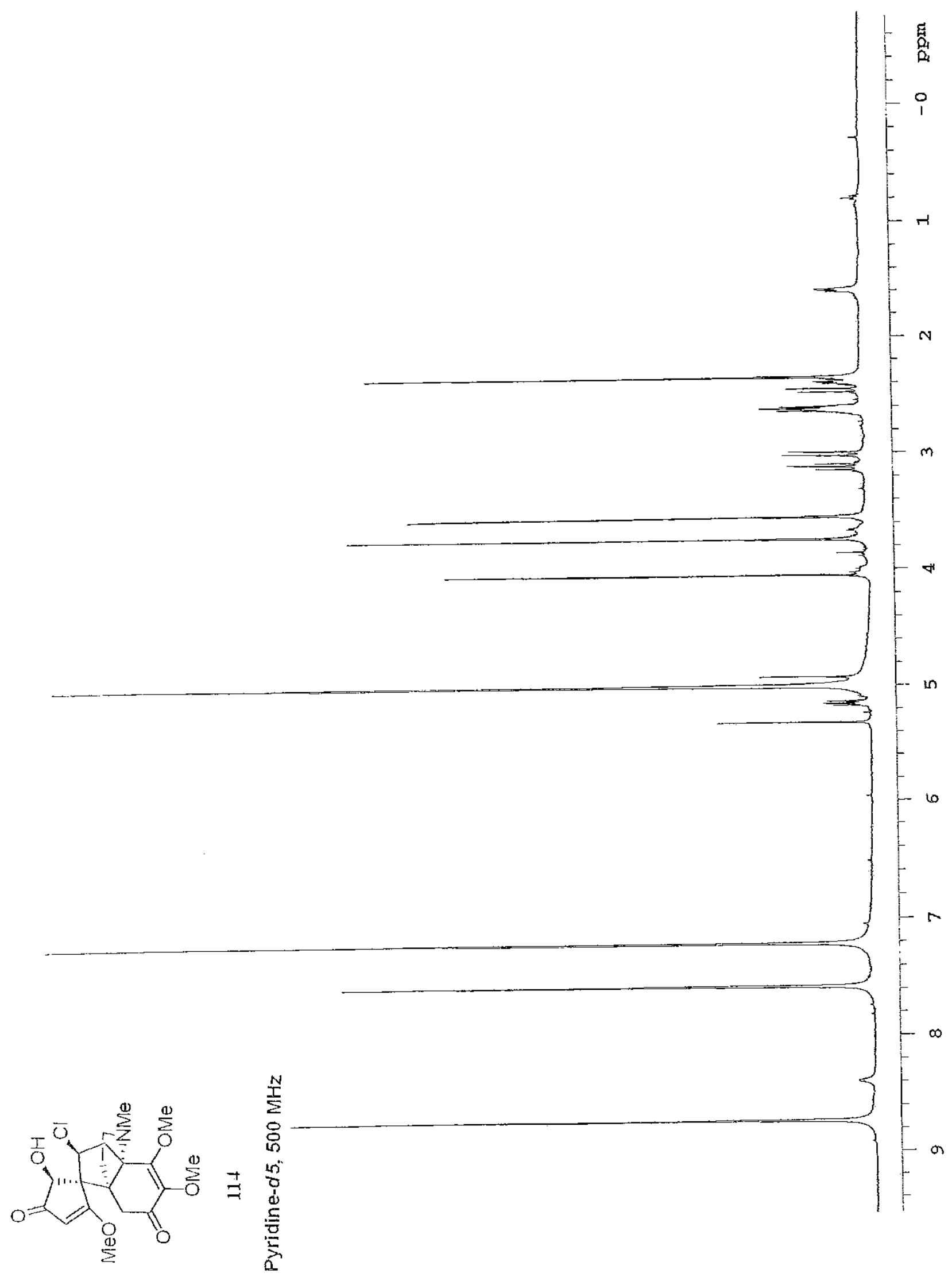




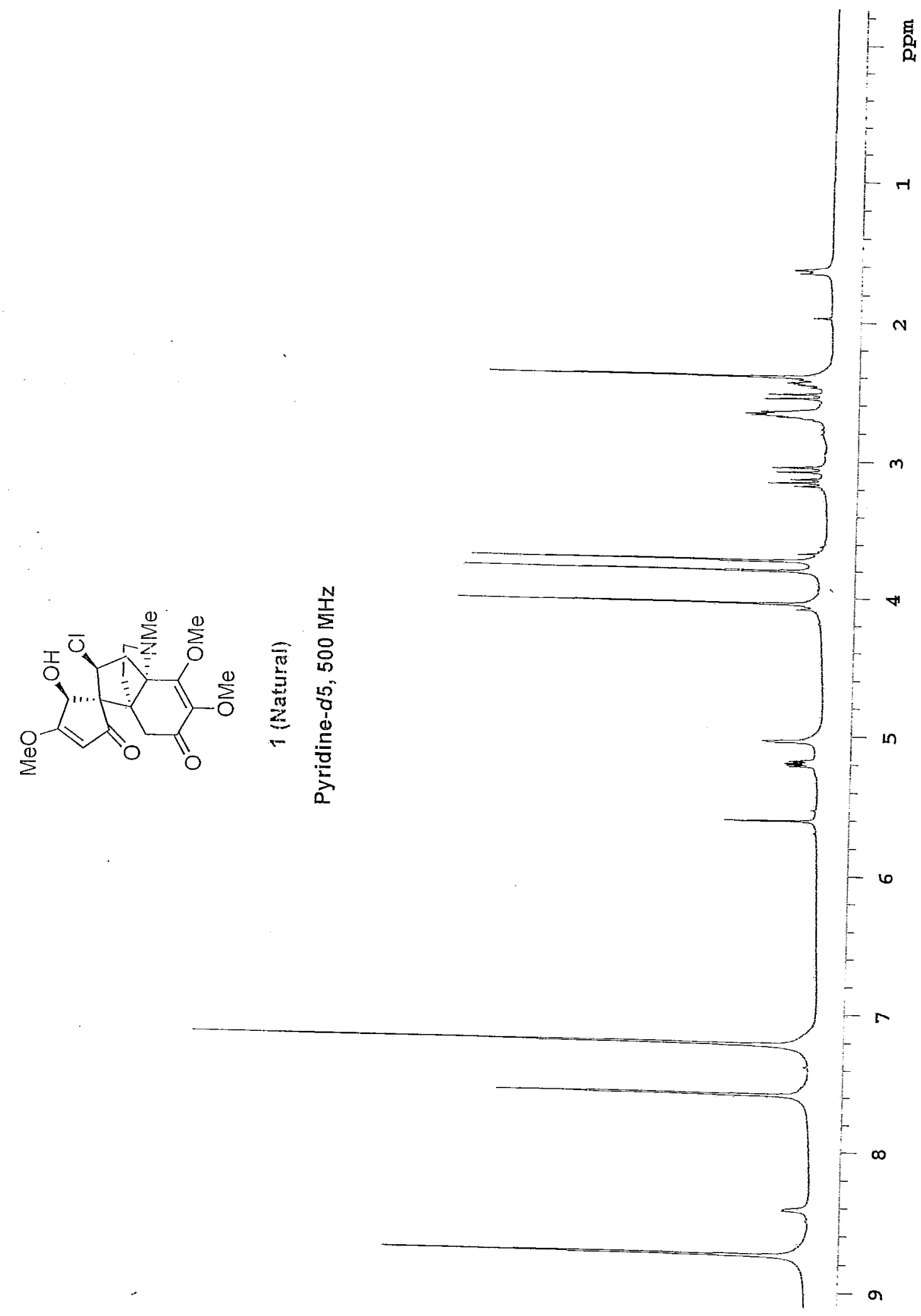




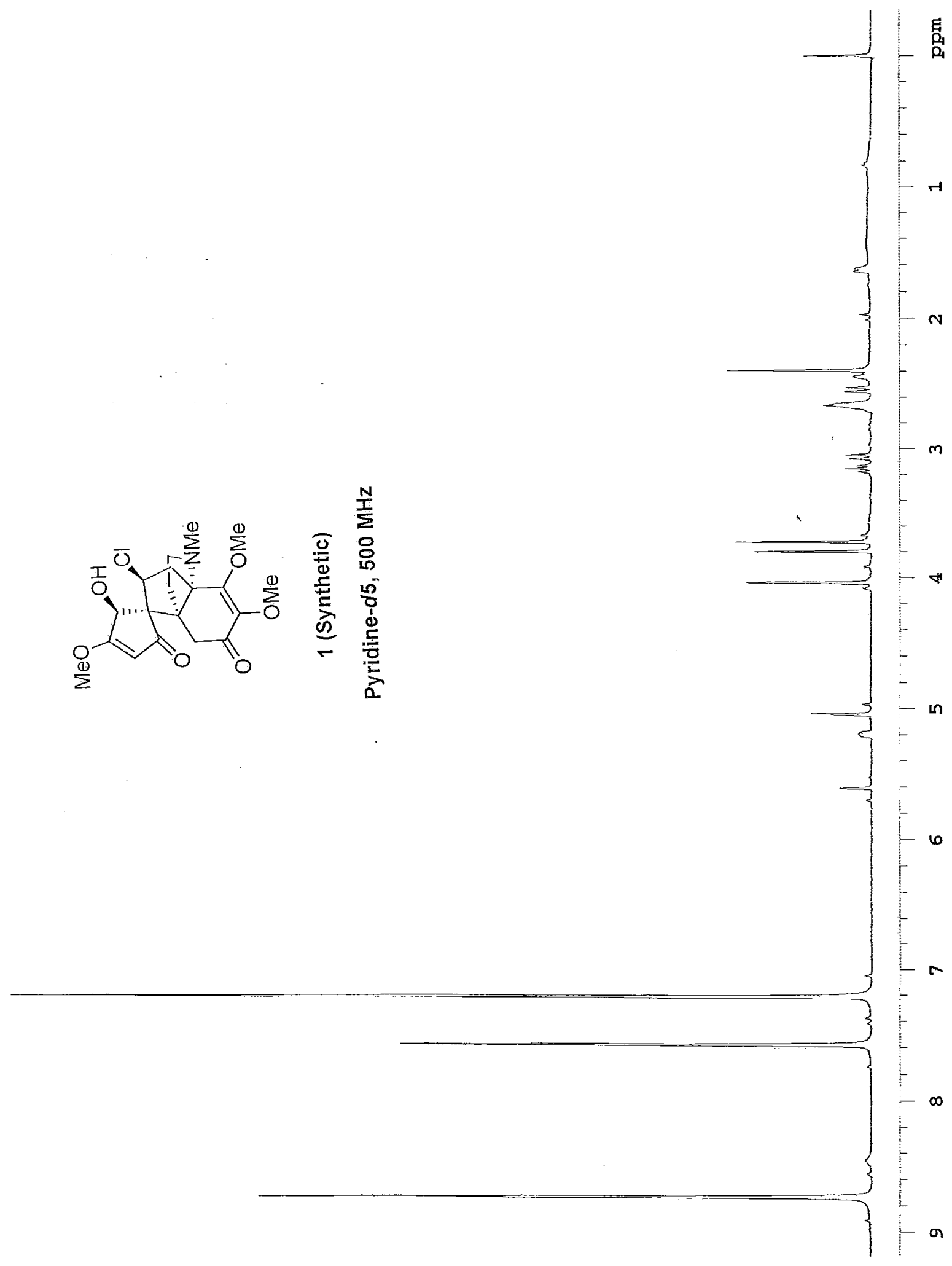



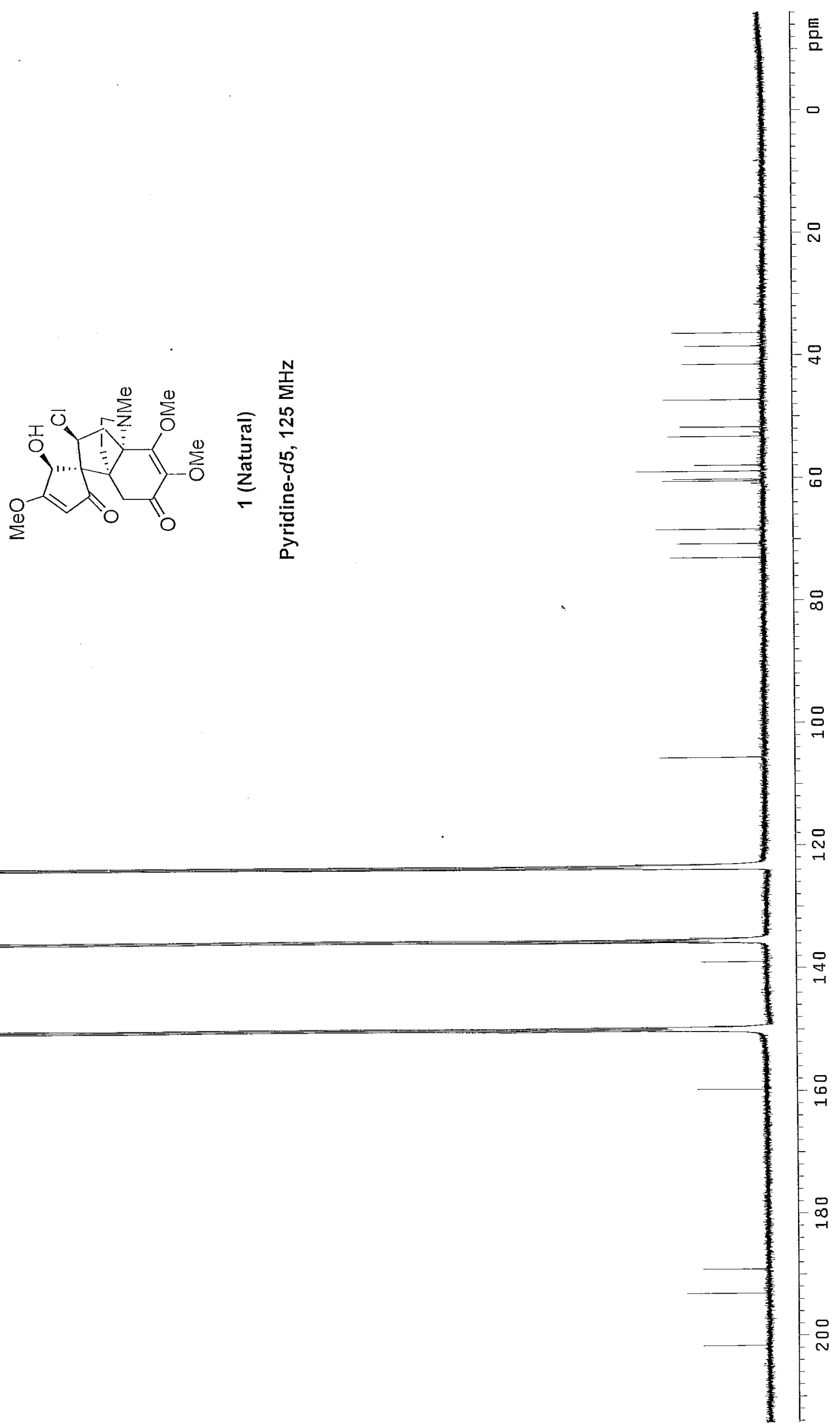


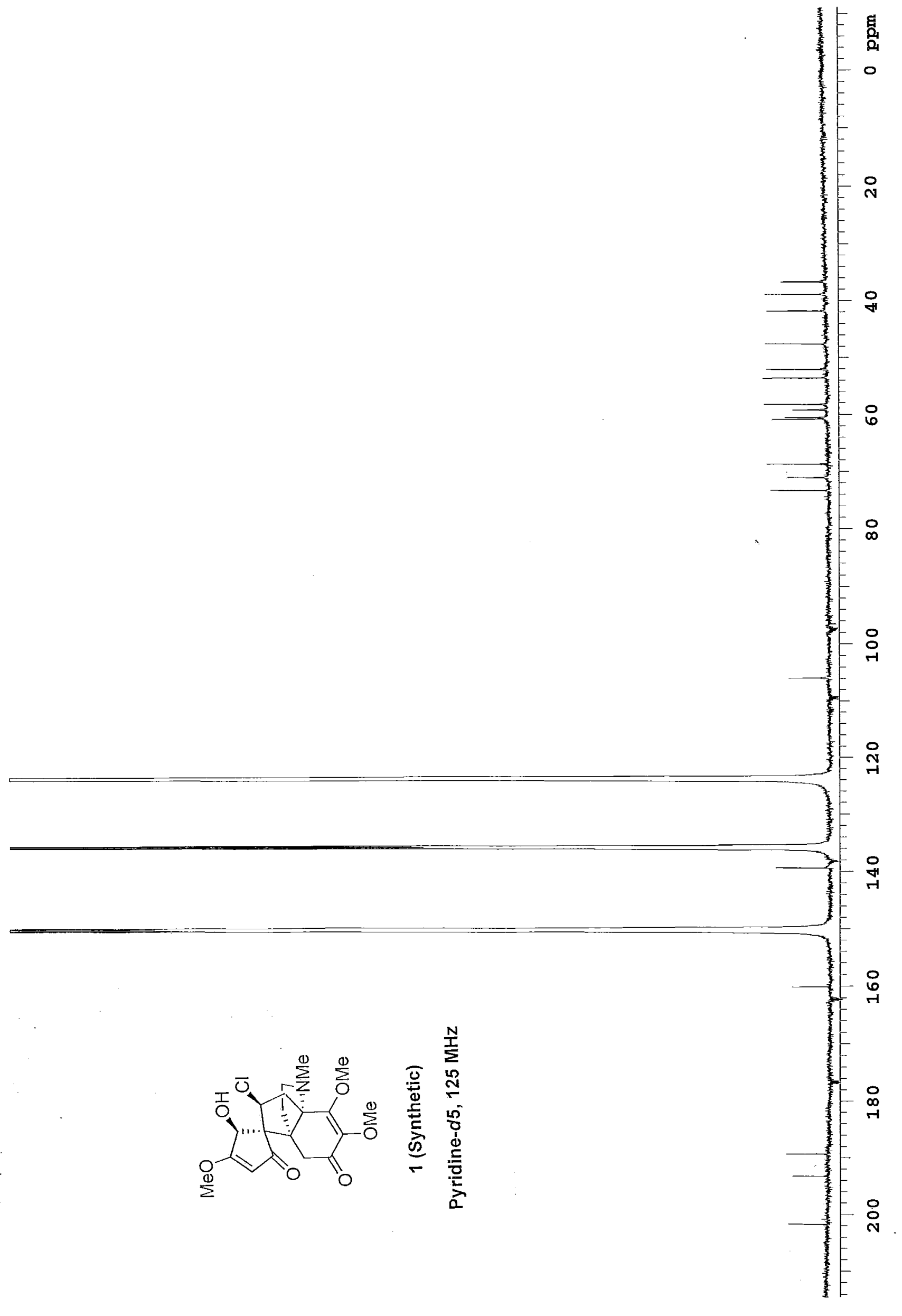

